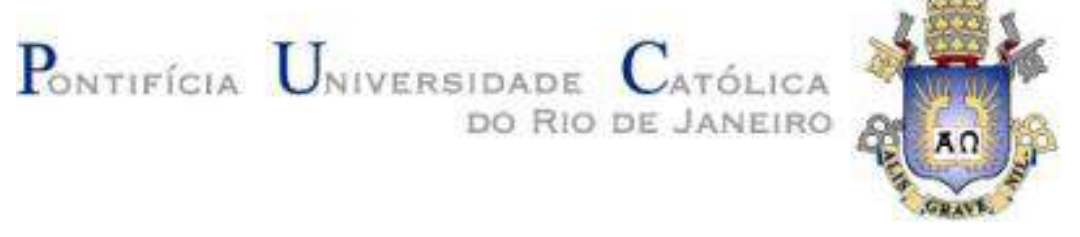

Carolina Marianna Bozzi Faya

A experiência do usuário (UX) em sítios de comércio eletrônico de vestuário: um estudo ergonômico

\begin{abstract}
DISSERTAÇÃO DE MESTRADO
Dissertação apresentada ao Programa de Pósgraduação em Design da PUC-Rio como requisito parcial para obtenção do grau de Mestre em Design.
\end{abstract}

Orientador: Prof.a. Cláudia Mont’Alvão 


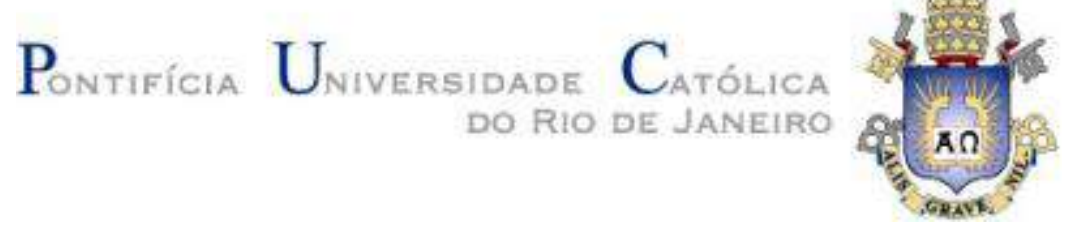

Carolina Marianna Bozzi Faya

\section{A experiência do usuário (UX) em sítios de comércio eletrônico de vestuário: um estudo ergonômico}

Dissertação apresentada ao Programa de Pósgraduação em Design da PUC-Rio como requisito parcial para obtenção do grau de Mestre em Design. Aprovada pela Comissão

Examinadora abaixo assinada.

Profa. Claudia Renata Mont'Alvão Bastos Rodrigues
Orientador
Departamento de Artes \& Design - PUC-Rio

Prof. Lucas da Rosa Universidade do Estado de Santa Catarina - UDESC

Profa. Luiza Novaes

Departamento de Artes \& Design - PUC-Rio

Profa. Monah Winograd Coordenadora Setorial do Centro de Teologia e Ciências Humanas - PUC-Rio

Rio de Janeiro, 28 de fevereiro de 2018 
Todos os direitos reservados. É proibida a reprodução total ou parcial do trabalho sem autorização da universidade, da autora e do orientador.

\section{Carolina Marianna Bozzi Faya}

Formou-se em Desenho Industrial na Pontifícia Universidade Católica do Rio de Janeiro com habilitação em Comunicação Visual em 2000. Especializou-se em Marketing na FGV em 2002. Atuou no mercado de design, moda e marketing e atualmente dedica-se à vida acadêmica e à Educação.

Ficha Catalográfica

Faya, Carolina Marianna Bozzi.

A experiência do usuário (UX) em sítios de comércio eletrônico de vestuário: um estudo ergonômico / Carolina Bozzi; orientadora: Cláudia Mont'Alvão. - 2018.

271 f. : il. (color.) ; $30 \mathrm{~cm}$

Dissertação (mestrado) - Pontifícia Universidade Católica do Rio de Janeiro, Departamento de Artes e Design, 2018.

Inclui referências bibliográficas.

1. Artes e design - Dissertações. 2. E-commerce. 3. Usabilidade. 4. Interação humano-computador. 5. UX. 6. Vestuário I Mont'alvão, Claudia. II. Pontifícia Universidade Católica do Rio de Janeiro. Departamento de Artes e Design. III. Título. 
À minha família - Ao meu marido Faya, por sempre me apoiar em minhas escolhas e aos meus pais e minha irmã, por me incentivarem e torcerem para o meu sucesso. 


\section{Agradecimentos}

Ao $\mathrm{CNPq}$ e à PUC-Rio, pelos auxílios concedidos, sem os quais este trabalho não poderia ter sido realizado.

À minha orientadora Cláudia Mont'Alvão por ter acreditado no meu projeto desde o início e por ter me guiado com tanta sabedoria nesta jornada.

Ao Faya, meu marido, por seu apoio incondicional a todas as minha escolhas e projetos.

À minha mãe, Solange, por ser minha maior torcida e me incentivar a seguir os meus caminhos.

Ao meu pai, Paulo, meu revisor implacável.

À minha irmã, Marcella, por ser minha aliada eterna.

À minha querida professora Ana Bia, sem seu apoio inicial não teria sido possível a realização desse sonho.

A todos os meus colegas e amigos (e foram muitos!) que de uma forma ou de outra me ajudaram e me estimularam.

Aos voluntários que participaram das entrevistas e questionários, eles foram fundamentais para a realização deste trabalho. 


\section{Resumo}

Faya, Carolina Marianna Bozzi; Mont'Alvão, Cláudia. A experiência do usuário (UX) em sítios de comércio eletrônico de vestuário: um estudo ergonômico, Rio de Janeiro, 2018. 271p. Dissertação de Mestrado - Departamento de Artes \& Design, Pontifícia Universidade Católica do Rio de Janeiro.

A comercialização de roupas on-line impõe alguns desafios para quem as compra e para quem as vende, pois tratam-se de produtos com os quais as pessoas ainda sentem a necessidade de ter um contato físico. Alguns de seus atributos são dificilmente comunicados digitalmente como a textura e o caimento do tecido. Soma-se a isto a falta de padronização de tamanhos praticada pela indústria de vestuário e o resultado é um cenário que sucita diversas dúvidas no consumidor/usuário. Objetivou-se com esta dissertação elaborar diretrizes que possam contribuir com o design de sítios de comércio eletrônico de vestuário feminino mais eficientes, eficazes e satisfatórios, proporcionando uma experiência do usuário (user experience em inglês, originando a sigla UX) positiva. Alguns métodos e técnicas foram usados em duas fases: a pesquisa exploratória e a descritiva. A fase da pesquisa exploratória foi constituida por uma entrevista exploratória, um questionário on-line e uma entrevista com especialistas de moda. Foi possível constatar que o maior problema enfrentado pelos consumidores/usuários ao comprar peças de roupas on-line está relacionado às medidas e à vestibilidade das peças. Além de ser um problema de usabilidade, por induzir os usuários ao erro, verificou-se que seu impacto maior era sobre a experiência do usuário uma vez que pode criar uma expectativa negativa em relação a interação com o sistema. $\mathrm{Na}$ fase da pesquisa descritiva os usuários foram divididos em dois grupos e solicitados a realizar um teste de usabilidade em um sítio de comércio eletrônico selecionado para avaliar sua interação ao comprar peças de roupas. Um grupo utilizou um desktop/laptop e o outro um smartphone. Ao finalizar as tarefas os usuários eram solicitados a responder a um debriefing e ao questionário AttrakDiff2 ${ }^{\mathrm{TM}}$. Por fim os dados obtidos foram analisados e os 
resultados dos testes realizados nos dois dispositivos (desktop/laptop e o outro um smartphone) comparados a fim de avaliar se houve diferenças na UX. Observouse que existe uma falta de conhecimento técnico por parte de usuário em relação aos atributos das peças de roupas, eles não sabem identificar os tipos de tecido e sentem-se extremamente inseguros quanto às informações de medidas fornecidas pelas empresas. Existe uma falha na comunicação destes atributos na medida que não são apresentadas de uma forma que facilite o seu entendimento pelos usuários seguindo os seus modelos mentais. Não confirmou-se uma diferença significativa na UX ao comparar a interação com os dois tipos de dispositivos. Ao final desta dissertação, são listadas diretrizes para aprimorar a UX ao interagir com sítios eletrônicos que comercializam peças de vestuário.

\section{Palavras-chaves}

E-commerce; usabilidade; interação humano-computador; $U X$; vestuário. 


\section{Abstract}

Faya, Carolina Marianna Bozzi; Mont'Alvão, Cláudia (Advisor). The user experience (UX) on fashion websites: an ergonomic study. Rio de Janeiro, 2018. 271p. Dissertação de mestrado - Departamento de Artes e Design, Pontifícia Universidade Católica do Rio de Janeiro.

Selling clothes online poses some challenges for those who buy them and for those who sell them, they are products with which people still feel the need to have a physical contact. Some of its attributes are not easily communicated digitally as the fit and the feel of a fabric. Besides, the lack of standardization of sizes practiced by the clothing industry results in a scenario that raises several doubts to the consumer/user. The objective of this dissertation is to elaborate guidelines that may contribute to the design of more efficient, effective and satisfactory female e-commerce websites, thus providing a positive user experience (UX). Some methods and techniques were used and sorted into two stages: an exploratory and a descriptive research approach. The exploratory research consisted of an exploratory interview, an online questionnaire and an interview with fashion specialists. It was possible to verify that the biggest problem faced by the consumers/users when buying clothes online is related to sizing and the wearability of the pieces. In addition to being a usability problem, by inducing users to errors, it was noted that its greatest impact was on the user experience as it can creat a negative expectation regarding the interaction with the system. To carry out the descriptive research, the users were divided into two groups and asked to do a usability test on a selected e-commerce website in order to evaluate their interaction when buying clothes. One group used a desktop/laptop and the other a smartphone. At the end of the test, the users were asked to respond to a debriefing and the AttrakDiff2 ${ }^{\mathrm{TM}}$ questionnaire. Finally, the data was analyzed and the tasks carried out on the two devices (desktop / laptop and the other a smartphone) were compared in order to evaluate if there were differences in the UX. It has been found that there is a lack of technical knowledge on the part of the user regarding the attributes of clothing, the users 
do not know how to identify fabric types and they feel extremely insecure about the size information provided by the retail companies. The website fails to communicate these attributes in a way that facilitates the understanding by users and that follows their mental models. There was no significant difference in UX when comparing the interaction on the two types of devices. At the end of this dissertation, there is a list of guidelines elaborated with the objective to improve the UX on female fashion websites.

\section{Keywords}

E-commerce; usability; human-computer interaction; UX; apparel. 


\section{Sumário}

1 Introdução 22

1.1 Tema 22

1.2 Problema 23

1.3 Objetivos 24

1.3.1 Objetivo geral 24

1.3.2 Objetivos específicos $\quad 24$

1.4 Pressupostos 24

1.5 Objeto de pesquisa 25

1.6 Justificativa 25

1.6.1 O segmento de moda e acessórios 27

1.6.2 O e-commerce facilitando o acesso a bens de consumo 27

1.6.3 A experiência do usuário (UX) 28

$\begin{array}{lll}1.7 & \text { Metodologia de pesquisa } & 29\end{array}$

$\begin{array}{lll}1.8 & \text { Estrutura da pesquisa } & 30\end{array}$

2 Apresentação das definições e conceitos da pesquisa 32

2.1 Ergonomia 32

2.2 ISO-9241: ergonomia da interação humano-sistema 33

2.3 Princípios de usabilidade 34

2.4 Experiência do usuário (UX) 46

2.5 Usabilidade desktop vs. Usabilidade móvel 50

2.5.1 O impacto do tamanho da tela na usabilidade 52

2.5.2 Diferenças na alimentação de informações no 53

desktop/laptop e no smartphone

2.5.3 O uso móvel comparado ao uso desktop/laptop 55

2.5.4 Diferenças de performance e desempenho no 56

desktop/laptop e no smartphone

2.6 Observações sobre o Capítulo 2 
3 E-commerce, seus conceitos, aspectos ergonômicos e 59 o consumidor on-line

$3.1 \quad$ E-business e e-commerce 60

3.2 Principais conceitos do e-commerce 61

3.3 Panorama mundial e nacional do e-commerce 63

$3.40 \mathrm{~m}$-commerce $\quad 65$

3.5 Ergonomia e usabilidade no comércio eletrônico 66

$\begin{array}{lll}3.6 & \text { Usabilidade para o } \text { m-commerce } & 71\end{array}$

$\begin{array}{lll}3.7 & \text { Modelos mentais } & 72\end{array}$

3.8 Comportamento do consumidor: on-line e off-line 74

$\begin{array}{lll}3.9 & \text { Risco percebido } & 79\end{array}$

3.10 Dificuldades ao comprar em sítios de comércio eletrônico 82 de vestuário

3.11 Omnichannel 83

3.12 Observações sobre o capítulo 3

4 Moda, modelagem, medidas e corpo: uma apresentação 87

4.1 A moda como uma forma de comunicação 87

4.1.1 O mercado de moda no Brasil 89

4.1.2 Panorama do comércio eletrônico de vestuário brasileiro 91

4.2 Modelagem 92

$\begin{array}{lll}4.3 & \text { Caimento e vestibilidade } & 94\end{array}$

4.4 Medidas 95

4.4.1 Tabela de medidas 95

4.4.2 Disparidade das medidas 98

4.4.3 NBR 13377 e NBR $15127 \quad 103$

4.4.4 Levantamento atropométrico Senai-Cetiqt 103

4.5 Tipos de corpos femininos 105

$\begin{array}{lll}4.6 & \text { Materiais têxteis } & 107\end{array}$

4.7 Observações sobre o capítulo 4 110

$5 \quad$ Práticas metodológicas: pesquisa exploratória 111 
$\begin{array}{lll}5.1 & \text { Levantamento bibliográfico }\end{array}$

5.1.1 Revisão narrativa da literatura 113

5.1.2 Revisão sistemática da literatura 113

5.2 Entrevista exploratória 114

5.2.1 Dados demográficos 115

$\begin{array}{ll}5.2 .2 \text { Perguntas qualitativas } & 117\end{array}$

5.2.3 Análise dos resultados da entrevista exploratória 118

5.3 Questionário on-line 123

5.3.1 Estrutura do questionário on-line 125

5.3.2 Resultados do questionário on-line 126

$\begin{array}{lll}5.4 & \text { Entrevista com especialistas } & 128\end{array}$

5.4.1 Análise de conteúdo da entrevista com os especialistas 129

5.4.2 Execução da análise de conteúdo 130

5.5 Resultados da entrevista com os especialistas 134

5.6 Seleção do sítio de comércio eletrônico para avaliação 135

5.7 Observações sobre o capítulo 5

6 Práticas metodológicas: pesquisa descritiva 138

$\begin{array}{lll}6.1 & \text { Teste de usabilidade } & 138\end{array}$

6.1.1 Escolha do sítio a ser utilizado no teste de usabilidade - 139 Pré-análise do dafiti.com.br

6.1.2 A estrutura do sítio da Dafiti 140

6.1.3 Tarefas do teste de usabilidade 147

6.1.4 Execução do teste de usabilidade 154

6.1.5 Teste em laboratório versus teste em campo 155

6.2 Questionário AttrakDiff2 ${ }^{\mathrm{TM}} 157$

6.3 Execução do AttrakDiff2 ${ }^{\mathrm{TM}} \quad 161$

$\begin{array}{ll}6.4 \text { Análise de tarefas } & 161\end{array}$

6.4.1 Análise de tarefas hierárquica 163

6.4.2 Execução da análise de tarefas 164

6.5 Observações sobre o capítulo $6 \quad 170$

7 Apresentação, análise e discussão dos resultados 173 
7.1 Resultados da fase da pesquisa descritiva

7.1.1 Resultados das perguntas de perfil 171

7.1.2 Resultados do teste de usabilidade 175

7.1.3 Resultados do quesitionário AttrakDiff2 ${ }^{\mathrm{TM}} \quad 179$

7.1.4 Resultados do debriefing 180

$\begin{array}{lll}7.2 \text { Sínteses } & 188\end{array}$

7.2.1 Síntese do resultados do teste de usabilidade 188

7.2.2 Síntese do resultados do questionário AttrakDiff2 ${ }^{\text {TM }} 191$

7.2.3 Síntese dos resultados do Debriefing 192

$\begin{array}{lll}7.3 \text { Observações gerais } & 196\end{array}$

7.4 Conclusão 197

8 Análise geral da pesquisa 200

$\begin{array}{lll}8.1 \text { Diretrizes } & 202\end{array}$

8.2 Experiência desktop/laptop versus experiência móvel 204

8.3 Desdobramentos da pesquisa 205

9 Referências bibliográficas 207

Apêndices $\quad 222$

Apêndice 1 - Materiais do questionário on-line 222

Apêndice 2 - Materiais da entrevista com especialistas 231

Apêndice 3 - Materiais do Teste de Usabilidade 252

Apêndice 4 - Questionário AttrakDiff2 ${ }^{\mathrm{TM}} 258$

Apêndice 5 - Vestuário 264

Anexos $\quad 268$

Anexo 1 - AttrakDiff2 ${ }^{\text {TM }}$ em inglês 268

Anexo 2 - Exemplos de tradução do AttrakDiff2 ${ }^{\mathrm{TM}}$ já utilizados $\quad 270$

Anexo 3 - Parecer do Comitê de Ética da PUC-Rio 271 


\section{Lista de figuras}

Figura 1.1 - Fatores que desmotivam as compras on-line 23

Figura 1.2 - Etapas da pesquisa exploratória 30

Figura 1.3 - Etapas da fase da pesquisa descritiva 30

Figura 2.1 - Definição de usabilidade e UX 48

Figura 2.2 - Palavras-chaves relacionadas com a qualidade 49 hedônica e qualidades pragmáticas

Figura 2.3 - Área "invisível" em torno do alvo de toque 54

Figura 2.4 - Equação móvel $\quad 53$

Figura 3.1 - Números do e-commerce 64

Figura 3.2 - Distribuição da compras feitas por meio da internet 64 pelas Regiões do País no primeiro semestre de 2017

Figura 3.3 - Perfil dos compradores no primeiro semestre de 201765

Figura 3.4 - Dispositivo preferido para comprar on-line 66

Figura 3.5 - Fases do processo decisório de compra 75

Figura 3.6 - Fontes de informação para tomada de decisão de 78 compra

Figura 3.7 - O processo decisório do consumidor e os modos de 79 comunicação associados

Figura 3.8 - Um contínuo do comportamento decisório de compra 80

Figura 3.9 - Motivos para consumidores comprarem em lojas 82 físicas

Figura 3.10 - Dispositivos usados para efetuar uma compra 84

$\begin{array}{ll}\text { Figura } 4.1 \text { - Distribuição por gênero } & 91\end{array}$

Figura 4.2 - Exemplo de base de blusa feminina 93 
Figura 4.3 - Fio em linha reta e em viés

Figura 4.4 - Comparação entre marcas: camisa feminina tamanho P 100

Figura 4.5 - Comparação de tamanhos entre referencias e marcas 100

Figura 4.6 - Biótipos do corpo feminino 106

Figura 4.7 - Distribuição da forma corporal das mulheres da 107 Região Sudeste

Figura 4.8 - Configuração das estruturas dos tecidos 108

Figura 4.9 - Ilustração das folgas de uma roupa 109

Figura 5.1 - Idade e gênero dos entrevistados 119

Figura 5.2 - Escolaridade dos entrevistados 119

Figura 5.3 - Frequência de compras on-line dos entrevistados 120

Figura 5.4 - Distribuição dos entrevistados 120

Figura 5.5 - Idade e gênero dos participantes do questionário 127

Figura 5.6 - Escolaridade dos participantes do questionário 127

Figura 5.7 - Nuvem com frequência de palavras-chaves ditas 133 pelos especialistas de moda nas entrevistas

Figura 6.1 - Homepage do sítio dafiti.com.br acessado por meio de 141 um laptop/desktop

Figura 6.2 - Menu mouseover: um sub-menu ativado por mouseover

Figura 6.3 - Homepage da categoria feminino

Figura 6.4 - Rodapé do sítio da Dafiti

Figura 6.5 - Página de Produtos do sítio da Dafiti

Figura 6.6 - Página de Apresentação do Produto do sítio da Dafiti

Figura 6.7 - Detalhes do produto na Página de Apresentação do Produto no sítio da Dafiti

Figura 6.8 - Homepage do sítio móvel da Dafiti 
Figura 6.9 - Página de Produtos e Página de Filtros do sítio móvel 145 da Dafiti

Figura 6.10 - Página de Apresentação do Produto do sítio móvel da 146 Dafiti

Figura 6.11 - Rodapé e Página de Dúvidas Frequentes do sítio móvel da Dafiti

Figura 6.12 - Exemplo de base de camisa feminina

Figura 6.13 - Exemplo de base de blusa feminina

Figura 6.14 - Etapas da fase da pesquisa descritiva 150

Figura 6.15 - HTA para comprar um DVD 155

Figura 6.16 - Representação gráfica de uma análise de tarefas para 163 comprar um DVD

Figura 6.17 - Análise da Tarefa 1 no sítio completo 165

Figura 6.18 - Análise da Tarefa 2 no sítio completo 165

Figura 6.19 - Análise da Tarefa 3 no sítio completo 166

Figura 6.20 - Análise da Tarefa 4 no sítio completo 167

Figura 6.21 - Análise da Tarefa 1 no sítio móvel 168

Figura 6.22 - Análise da Tarefa 2 no sítio móvel 168

Figura 6.23 - Análise da Tarefa 3 no sítio móvel 169

Figura 6.24 - Análise da Tarefa 4 no sítio móvel 169

Figura 7.1 - Amostra escolhida para as participantes do teste de 172 usabilidade

Figura 7.2 - Perfil das voluntárias participantes do teste de usabilidade 173

Figura 7.3 - Frequência de compras on-line, desktop/laptop vs. 174 Smartphone

Figura 7.4 - Perfil das voluntárias do teste de usabilidade, 175 desktop/laptop vs. Smartphone

Figura 7.5 - Cumpriu/Não Cumpriu/Desistiu da tarefa no teste de usabilidade 
Figura 7.6 - Número de passos necessários para cumprir as tarefas 178

Figura 7.7 - Resultados AttrakDiff2 ${ }^{\text {TM }} 179$

Figura 7.8 - Respostas à pergunta: "As informações no sítio para a 185 sua compra foram: suficientes-insuficientes"

Figura 7.9 - Alguns dos tamanhos disponíveis no filtro de tamanhos, 190 sítio móvel e do sítio completo

Figura 7.9 - Imagem com aparência de link 197

Figura 8.1 - Inconsistência de informação 205

Figura A.1 - Etapas da construção e da reprodução de roupas 264

Figura A.2 - Medidas do corpo feminino 267 


\section{Lista de tabelas}

Tabela 5.1 - Distribuição de volume de compras por região no

Brasil

Tabela 5.2 - Razões para comprar on-line

Tabela 5.3 - Razões para não comprar roupas on-line

Tabela 5.4 - Frequência das unidades de contexto nas entrevistas com os especialistas

Tabela 7.1 - Escolaridade das voluntárias participantes do teste de usabilidade

Tabela 7.2 - Tipo de tabela de medidas que encontrou

Tabela 7.3 - Número de passos necessários para cumprir as tarefas

Tabela 7.4 - Respostas negativas à pergunta: "A tabela de medidas continha informações claras?".

Tabela 7.5 - Respostas afirmativas à pergunta: "A tabela de medidas continha informações claras?"

Tabela 7.6 - Respostas negativas à pergunta: "Você sente-se segura em relação às informações sobre o caimento da roupa?"

Tabela 7.7 - Respostas afirmativas à pergunta: Você sente-se segura em relação às informações sobre o caimento da roupa?"

Tabela 7.8 - Respostas negativas à pergunta: "Com base nas informações disponíveis você tem segurança de que o tamanho escolhido está correto?"

Tabela 7.9 - Respostas afirmativas à pergunta: "Com base nas informações disponíveis você tem segurança de que o tamanho escolhido está correto?"

Tabela 7.10 - Respostas à pergunta: "As políticas de trocas estão claras?"

Tabela 7.11 - Respostas à pergunta: "Geralmente, quando você compra on-line o preço é um fator decisório?" 
Tabela 7.12 - Respostas à pergunta: "Quais outros fatores

influenciam sua decisão de compra? (Além do preço)"

Tabela 7.13 - Respostas à pergunta: "Como você escolheu o seu tamanho?" 


\section{Lista de quadros}

Quadro 2.1 - Princípios relacionados ao objetivo de facilitar o

aprendizado do sistema

Quadro 2.2 - Princípios relacionados ao objetivo de facilitar a procura, a percepção, o reconhecimento e a compreensão das informações no sistema

Quadro 2.3 - Princípios relacionados ao objetivo de facilitar o controle da interação com o sistema

Quadro 2.4 - Princípios relacionados ao objetivo de considerar o contexto de uso do sistema e o tipo de usuário

Quadro 2.5 - Comparação entre mouse e dedos como dispositivos de entrada de informações

Quadro 3.1 - Diretrizes para sítios on-line

Quadro 4.1 - Exemplo de tabela de medidas

96

Quadro 4.2 - Comparativo de medidas

Quadro 6.1 - Cenários utilizados no teste de usabilidade e seus objetivos 
Ao expandirmos o campo do conhecimento apenas aumentamos o horizonte da ignorância.

Henry Miller. 


\section{Introdução}

\section{1.}

Tema

A expansão do comércio eletrônico deve-se principalmente à introdução da banda larga no Brasil em 2003 e mais recentemente à popularização dos smartphones com acesso à internet, quando ao final de 2007 a oferta de serviços 3G teve início no País ("Plano Nacional da Banda Larga (PNBL)", 2006). O número de usuários da rede mundial de computadores vem aumentando significativamente, incluindo o acesso via dispositivos móveis. De acordo com dados do IBGE (INSTITUTO BRASILEIRO DE GEOGRAFIA E ESTATÍSTICA, 2014) dos domicílios conectados à internet, o acesso por meio de telefones móveis alcançou o índice de 80\% em 2014 e, pela primeira vez, ultrapassou o acesso por meio de computadores pessoais (desktops, notebooks e laptops). Pode considerar-se que questões envolvendo a usabilidade muitas vezes não são levadas em conta por projetistas, sobre ser as necessidades do usuário ignoradas (MIRANDA, 2004). Essas questões ampliam-se no acesso à internet via telefones móveis: como os sítios frequentemente são otimizados para usabilidade desktop, eles não seguem as diretrizes necessárias para o bom uso no acesso móvel, logo o resultado são sítios mal projetados (NIELSEN; BUDIU, 2014 e NIELSEN, 2011), sobretudo no que refere-se à aquisição de peças de vestuário. O usuário/consumidor não tem contato visual e tátil direto com a peça antes de adquiri-la e tampouco a 'experimenta'. Isto considera-se um fator de desestímulo à compra on-line para 84\% dos usuários, segundo o Sebrae (2015) (Figura 1.1). Contudo, mesmo diante dessa barreira entre o real e o digital, no primeiro semestre de 2017, o setor de moda e acessórios foi o segmento líder em volume de pedidos via comércio eletrônico no Brasil. Esse dado indica o potencial 
existente de expansão desse mercado, beneficiando a economia e a indústria brasileiras.

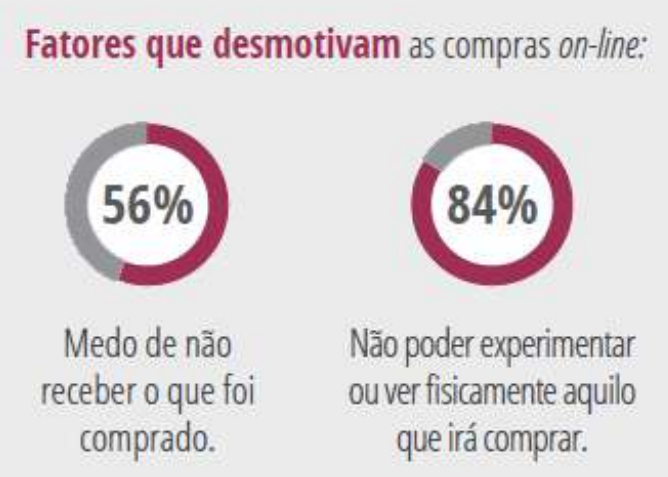

Figura 1.1 - Fatores que desmotivam as compras on-line. Fonte: ("Relatório de Inteligência.", 2015, p. 2)

Essa dissertação insere-se no campo de pesquisa em Ergonomia e Usabilidade e Interação Humano-Computador. Trata-se de uma pesquisa descritiva e visa a melhoria da experiência do usuário de sítios de comércio eletrônico de vestuário feminino. Contudo, acredita-se que seus resultados possam ser aplicados a outros tipos de sítios.

\section{2.}

\section{Problema}

Com base nas premissas apresentadas no tema desta dissertação, definem-se os seguintes problemas de pesquisa:

- Quais são as dificuldades que um usuário enfrenta ao tentar comprar uma peça de roupa on-line?

- Quais são as informações de um produto que necessariamente precisam ser apresentadas em um sítio de comércio eletrônico de vestuário para ultrapassar a barreira da falta de contato físico?

- $\quad$ Até que ponto a usabilidade está sendo considerada como diretriz na construção dos sítios de comércio eletrônico de vestuário, levando em conta as características e singularidades dos dispositivos sendo utilizados?

- Como a usabilidade impacta na experiência do usuário? 


\section{3.}

\section{Objetivos}

\subsection{1.}

\section{Objetivo geral}

Esta pesquisa tem como objetivo geral elaborar diretrizes que possam contribuir com o design de sítios de comércio eletrônico de vestuário feminino mais eficientes, eficazes e satisfatórios, proporcionando uma experiência do usuário positiva.

\subsection{2.}

\section{Objetivos específicos}

Os objetivos específicos da pesquisa são:

- $\quad$ Compreender o processo de modelagem de vestuário;

- $\quad$ Compreender como se dá o mercado de moda no Brasil;

- $\quad$ Averiguar o contexto do e-commerce no Brasil;

- Identificar os pontos de maior dúvida para o usuário no que tange à usabilidade de sítios de comércio eletrônico de vestuário;

- Analisar os principais obstáculos com os quais os usuários deparam-se, quando da tomada de decisão da compra on-line; e

- Comparar a experiência do usuário ao usar um smartphone com a sua experiência ao usar um desktop.

\section{4.}

\section{Pressupostos}

A presente dissertação está fundamentada sobre os seguintes pressupostos:

P1: A falta de conhecimento sobre o usuário e de seus modelos mentais resultam em projetos de interface confusos. 
P2: As informações fornecidas sobre o produto de vestuário (por exemplo: modelagem, materiais, dimensões, etc.) são insuficientes ou superficiais e dificultam a tomada de decisão do consumidor, aumentando a barreira entre o real e o virtual, impactando a satisfação percebida.

P3: A transposição direta dos sítios completos (destinados a desktops) e a falta de hierarquização e priorização das informações ao projetar sítios móveis dificultam o processo de compra e resultam em um sítio com um baixo grau de usabilidade.

\section{5.}

\section{Objeto de pesquisa}

Esta pesquisa tem como objeto a experiência do usuário decorrente do processo de compra em sítios de e-commerce (comércio eletrônico) desenvolvidos para o segmento de moda feminina para acesso por meio de smartphones e desktops/laptops.

\section{6.}

\section{Justificativa}

Um sítio deve estar adaptado às necessidades do usuário, e não o usuário adaptar-se ao sítio. Se este estiver sendo acessado de um dispositivo móvel, deve considerar-se tanto a adequação e as necessidades do usuário, quanto os diversos contextos de uso em que esteja inserido. A ISO 9241-11 (ABNT, 2002) define usabilidade como: "medida na qual um produto pode ser usado por usuários específicos com eficácia, eficiência e satisfação em um contexto específico de uso". A definição da International Standards Organization, a ISO, trata a usabilidade não como uma qualidade isolada de um produto, mas o seu diálogo com o usuário, o objetivo da tarefa que aquele está executando e o ambiente onde esse produto está inserido. (CHAMMAS; QUARESMA; MONT'ALVÃO, 2013 e JORDAN, 2001). A falta de usabilidade pode causar problemas cujas consequências aborrecem ou frustram um usuário e impactam negativamente a sua experiência. 
Moraes define:

Como conceito, a usabilidade trata de adequação entre o produto e as tarefas a cujo desempenho ele se destina, da adequação com o usuário que o utilizará, e da adequação ao contexto em que será usado (MORAES, 2013, p.7).

A usabilidade, quando considerada de forma adequada, dirime dúvidas na navegação do usuário. Ao projetar um sítio, o designer deve incluir em suas atribuições um checklist de interrogações acerca da clareza de compreensão por parte do usuário (KRUG, 2006).

Se existem inúmeros indícios de erros de usabilidade em projetos de sítios para um computador convencional, estes se multiplicam em projetos para versões móveis (celulares, tablets, dentre outros). Muitas empresas adotam uma versão de sítio responsivo, na qual é feita apenas uma adaptação de 'tamanho' do sítio do desktop para o celular ou tablet.

Simplesmente usar um projeto Web responsivo para deixar o site completo acessível nos dispositivos móveis frequentemente resulta em uma EU (experiência do usuário) móvel abaixo do padrão (NIELSEN; BUDIU, 2014, p. 33).

Essa adaptação deve levar em consideração que as características daqueles dispositivos são totalmente diferentes. Além das telas pequenas, os celulares são comandados por gestos no lugar de mouses. Também devem ser considerados os fatores externos ao usá-los, como interrupções de tarefa e sinal intermitente (MENDOZA, 2014). Projetar sítios móveis pensando no desempenho também irá beneficiar a eficiência do sítio completo (WROBLEWSKI, 2011). Sítios móveis são aqueles projetados para dispositivos móveis como: telefones celulares, tablets e $e$ readers, sítios completos são aqueles projetados para desktops e laptops. A título de esclarecimento, embora laptops sejam portáteis, não são transportados tão facilmente como smartphones (BELL, 2016). Ademais, a experiência de uso nestes dispositivos equipara-se a de um desktop, ambos têm telas grandes e suportam a navegação de sítios completos, portanto para esta pesquisa laptops e desktops serão agrupados na mesma categoria: de estações de trabalho fixas.

Com a consolidação da indústria de dispositivos móveis e a popularização do e-commerce, a usabilidade é um fator de diferenciação competitiva fundamental e torna-se um atributo principal de qualidade (INOSTROZA et al., 2012). A escolha do usuário recai sobre o produto mais adequado às suas 
necessidades, a usabilidade tornou-se um critério fundamental para a tomada de decisão de compra, bem como a funcionalidade, estética, preço ou a divulgação do produto. Com o intuito de auxiliar o usuário no processo da tomada de decisão de compra, há teorias, métodos, recomendações de usabilidade para organizar a interação entre o produto e o homem (BRANGIER; BARCENILLA, 2003).

De modo que é relevante para a pesquisa elaborar diagnósticos e desenvolver estratégias que possam contribuir com projetos de sítios mais eficientes, eficazes e satisfatórios seja para acesso via dispositivos móveis quanto para acesso via desktops.

A forma de testar a usabilidade em um dispositivo móvel também deve ser diferente. Cabe considerar testes em situações reais a levar em conta a característica da portabilidade e a diversidade de contextos de uso em que será inserido (DUH; TAN; CHEN, 2006).

\subsection{1.}

\section{O segmento de e-commerce de moda e acessórios no Brasil}

Segundo a $36^{\text {a }}$ Webshoppers (E-BIT, 2017b), no primeiro semestre de 2017, o setor de Moda e Acessórios foi o segmento líder em volume de pedidos via $e$ commerce no Brasil, representando 14,8\% de todas as vendas realizadas por meio da internet, posição que vem sido mantida desde 2013. Apesar desse cenário bastante positivo, a barreira entre o real e o virtual e a disparidade das medidas adotadas por cada marca intensifica a falta de confiança do usuário em comprar produtos de vestuário on-line. A $29^{\mathrm{a}}$ edição do relatório Webshoppers (E-BIT, 2014) aponta em que $25 \%$ dos usuários tiveram a intenção de trocar e $27 \%$ a intenção de devolver um produto comprado on-line da categoria de Moda e Acessórios.

Um projeto de interface, levando em conta diretrizes de usabilidade quanto a qualidade das informações fornecidas ao usuário do sistema poderia aumentar sua confiança e diminuir as taxas de intenção de devolução e troca.

\subsection{2.}

\section{O e-commerce facilitando o acesso a bens de consumo}


O e-commerce também avalie-se-lhe como uma ferramenta para a democratização do acesso a bens de consumo por pessoas que residem distantes dos grandes centros urbanos, assim como em cidades do interior do Brasil. A internet é uma ferramenta facilitadora para pessoas residentes de cidade menores e portanto com mercados limitados, ela poupa os seus moradores do que Bell (2016) denomina 'a tirania da localização.

A usabilidade em sítios de e-commerce torna-se primordial para fazer com que esse canal seja ainda mais abrangente onde 'falar a linguagem do usuário' é essencial, considerando a diversidade da população brasileira. A usabilidade em dispositivos móveis é igualmente importante; de acordo com a Pesquisa Nacional por Amostra de Domicílios (PNAD) referente ao acesso à internet e à televisão e posse de telefone móvel celular para uso pessoal, realizada pelo IBGE e divulgada em $2014,11,5 \%$ da população brasileira utilizam a internet exclusivamente por meio de telefones móveis celulares, chegando a 43,0\% no Amapá, superando o uso do microcomputador para acesso à rede, colocando assim o papel do design a serviço da sociedade. De acordo com a mesma pesquisa, $75,4 \%$ da população do Norte do Brasil navegam na internet utilizando um telefone celular, por ser a região mais extensa do território nacional e com localidades remotas e também a mais dependente da banda larga móvel. Investir em usabilidade de sítios de $e$ commerce pode representar uma melhora significativa na experiência desses usuários, a despeito a velocidade de conexão e da visualização em telas menores.

Esta pesquisa partiu de uma experiência profissional no mercado da moda, quando o objetivo foi o da produção de conteúdo para plataformas digitais com a finalidade de que o usuário pudesse dispor do máximo de informações a fim de tomar a decisão de compra.

\subsection{3.}

\section{A experiência do usuário (UX)}

O processo de compra, nem sempre envolve decisões puramente racionais, valores culturais, o ambiente em que o sujeito está inserido, a percepção de risco são fatore, entre outros podem ser determinantes (KOTLER; KELLER, 2016). A usabilidade, sozinha, não dá conta de todos os aspectos da interação humana com sistemas. As abordagens baseadas somente na usabilidade são limitadas, pois 
tendem a ter uma visão dos produtos como meras ferramentas com as quais os usuários efetuam tarefas (JORDAN, 2000).

A ISO-9241 (ISO 9241-210, 2010) define a experiência do usuário (UX), como: "as percepções e respostas dos usuários resultantes do uso e/ou antecipação do uso de um produto, sistema ou serviço". A UX é o resultado dessa interação que tem um começo e um fim, produzindo memórias dessa experiência (ROTO et al., 2010).

Com o objetivo de medir a eficácia, a eficiência, a satisfação e os aspectos emocionais da interação humano-sistema, esta dissertação de mestrado considera tanto a usabilidade quanto a experiência do usuário. Essa equação visa a uma melhor compreensão dos impactos que a usabilidade causa na experiência do usuário ao utilizar sítios de e-commerce de vestuário feminino para efetuar compras.

\section{7.}

\section{Metodologia de pesquisa}

Pretende-se atingir os objetivos dessa pesquisa utilizando a seguinte metodologia:

- Levantamento bibliográfico (sistemático e narrativo);

- Entrevista informal (aberta) para posterior elaboração de questionário online;

- Desenvolvimento e aplicação de um questionário on-line;

- $\quad$ Entrevistas semiestruturadas com especialistas de moda;

- Levantamento e seleção do sítio de moda para avaliação de usabilidade;

- $\quad$ Teste de usabilidade seguido de um debriefing;

- $\quad$ Aplicação do questionário AttrakDiff2; e

- $\quad$ Análise de tarefas.

As etapas supracitadas foram divididas em duas fases: a de pesquisa exploratória e descritiva. O primeiro passo da fase exploratória foi uma série de entrevistas exploratórias com usuários, com base nos resultados foi elaborado um questionário on-line. Também fez parte desta primeira fase a realização de entrevistas com especialistas da área de moda, mais especificamente de modelagem (Figura 1.2). 


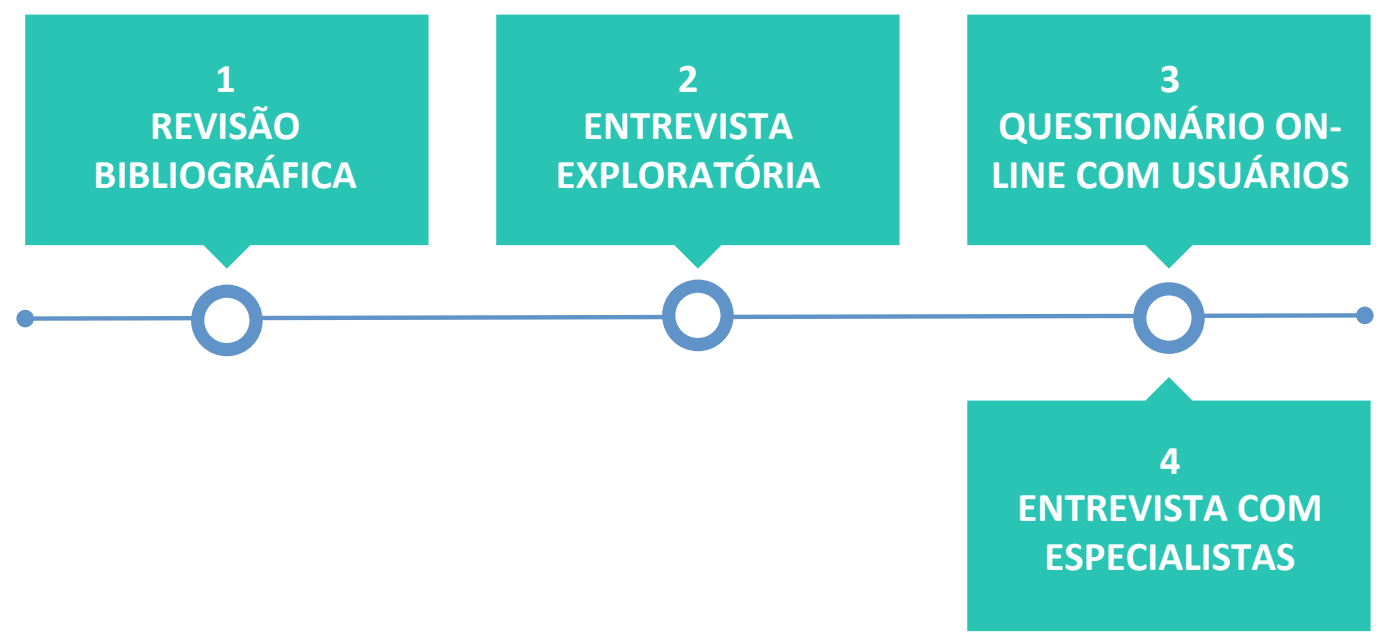

Figura 1.2 - Etapas da fase da pesquisa exploratória. Fonte: elaborado pela autora.

Após a conclusão da fase exploratória foi possível elaborar um teste de usabilidade para ser aplicado com usuários, estes primeiro respondiam um questionário inicial de perfil, realizavam as tarefas solicitadas no teste, ao finalizarem respondiam à um debriefing e finalizam respondendo ao questionário AttrakDiff $^{\mathrm{TM}}$ (Figura 1.3). As fases da pesquisa exploratória e descritiva serão pormenorizadas nos capítulos 5 e 6 , respectivamente, desta dissertação.

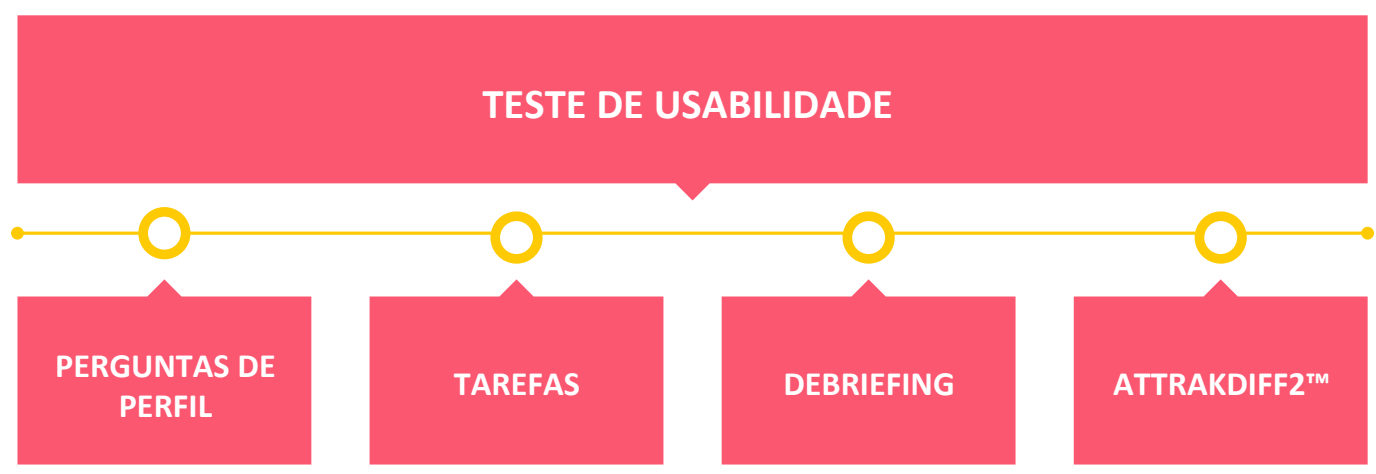

Figura 1.3 - Etapas da fase da pesquisa descritiva. Fonte: elaborado pela autora.

\section{8.}

\section{Estrutura da Pesquisa}

No capítulo 2 serão apresentados definidos os conceitos necessários para a leitura da dissertação, tais como: a ergonomia, a ISO-9241, os princípios de 
usabilidade, a experiência do usuário (UX) e a usabilidade em desktop/laptops e em smartphones.

No capítulo 3 será apresentado o cenário da pesquisa; um panorama mundial e nacional do e-commerce, uma breve cenário do $m$-commerce, questões ergonômicas do e-commerce. Abordará aspectos do comportamento do consumidor, seus mapas mentais ao utilizar um sítio de e-commerce, os estágios de compra, e o processo decisório. Além disso será discutida a estratégia da UX omnichannel.

O capítulo 4 será dedicado a discutir e apresentar aspectos do vestuário relevantes ao escopo deste estudo tais como: a moda como uma forma de comunicação, o mercado de moda no Brasil e o e-commerce, uma explicação sobre a modelagem de vestuário e o processo de criação de peças. Também irá expor conceitos de caimento e vestibilidade e por fim as medidas e como a falta de padronização influência o mercado de moda.

Os métodos e técnicas utilizados na fase da pesquisa exploratória serão abordados no capítulo 5, eles tiveram o intuito de levantar dados, são eles: entrevista exploratória, questionário, entrevista com especialistas. Também será contemplada a análise de conteúdo, fundada nos resultados da entrevista com especialistas.

Os métodos e técnicas utilizados na fase de pesquisa descritiva serão explicitados e conceituados no capítulo 6, são eles: teste de usabilidade, um debriefing, e a aplicação do questionário AttrakDiff2 ${ }^{\mathrm{TM}}$.

No capítulo 7, constam os resultados do teste de usabilidade, do debriefing e do questionário AttrakDiff2 ${ }^{\mathrm{TM}}$, as interpretações dos testes com a participação dos usuário, as ações e verbalizações dos participantes e a delimitação dos principais problemas encontrados no sítio de e-commerce de vestuário testado. Apresenta-se a síntese da discussão dos resultados obtidos na fase da pesquisa descritiva, a conclusão do trabalho e a discussão dos problemas levantados por meio dos métodos e técnicas utilizados para atingir os objetivos desta. Esse capítulo também abordará a possibilidade de futuros desdobramentos da pesquisa. 


\section{Apresentação das definições e dos conceitos da pesquisa}

Neste capítulo serão apresentados os conceitos que nortearão essa pesquisa; a ergonomia, os princípios de usabilidade, a experiência do usuário, e as qualidades hedônicas e pragmáticas de um produto. Para fins de esclarecimento, a palavra produto pode referir-se a um objeto, um software, um sistema, ou uma interface.

Também serão abordadas algumas diferenças entre a usabilidade desktop e a usabilidade móvel, a segunda, com ênfase nos smartphones, categoria de dispositivos móveis abordada nessa pesquisa.

\section{1.}

\section{Ergonomia}

A ergonomia, ou human factors ${ }^{1}$ (como é chamada em alguns países, entre eles, os Estados Unidos), pode ser definida como a ciência da adaptação do trabalho ao homem (GRANDJEAN, 1998). Pheasant (2003) define a ergonomia como a ciência do trabalho: das pessoas que trabalham e as maneiras como é feito; as ferramentas e equipamento que usam, o local e os aspectos psicológicos da situação de trabalho. O autor explica que a palavra 'trabalho' admite diversos significados e, de uma maneira simplesmente, é o que fazemos para viver. Em um sentido mais amplo, o termo 'trabalho' pode ser aplicado a qualquer atividade humana planejada e com propósito, particularmente se envolver um grau de habilidade e esforço. Portanto, para a ergonomia, a palavra trabalho é utilizada com seu sentido mais amplo, o de ocupacional.

Chapanis (1996) define a ergonomia como um corpo de informações sobre as habilidades, limitações e outras características humanas que são relevantes ao 
design. E define a engenharia da ergonomia como a aplicação de informações ergonômicas no design de ferramentas, sistemas, tarefas, trabalhos e ambientes para o uso humano eficiente, seguro e confortável. A ergonomia é uma ciência preocupada com o projetar, com o design. A abordagem da ergonomia ao design, pode ser resumida como: o princípio do design centrado no usuário. Se um objeto, um sistema ou um ambiente são projetados para o uso humano, então os seus projetos devem ser baseados nas características mentais e físicas de seus usuários, visando atingir a melhor combinação entre o produto e seu usuário no ambiente da tarefa a ser realizada (MORAES; MONT’ALVÃO, 2009). Em outras palavras, a ergonomia é a ciência de adaptar a tarefa ao trabalhador e o produto ao usuário (PHEASANT, 2003). Concentra-se no ser humano e na sua interação com produtos, equipamentos, procedimentos e ambientes no trabalho e no cotidiano (SANDERS; MCCORMICK, 1993).

\section{2.}

\section{ISO 9241: Ergonomia da interação humano-sistema}

A partir de 1980, com a popularização da informática, foram introduzidos postos de trabalho informatizados e máquinas programáveis em diferentes setores das atividades humanas. De uma forma geral, deixamos de ser uma sociedade industrial para nos tornarmos uma sociedade da informação (NAISBITT, 1982, apud (CHAPANIS, 1996). Essa nova maneira de trabalhar trouxe novos desafios à ergonomia que passou a ocupar-se também dos aspectos cognitivos (percepção, processamento de informações, tomada de decisões) do trabalho (IIDA; BUARQUE, 2016).

Com o uso crescente de computadores, máquinas automatizadas e robôs programáveis, o ser humano passou a programar e controlar essas máquinas, transferindo grande parte do trabalho físico pesado e repetitivo para elas. Essa fase marca a passagem da ergonomia física para a ergonomia cognitiva. Uma das maiores transformações ocorreu com a introdução da internet, foi inaugurada no Brasil na década dos 1990, que modificou substancialmente o trabalho humano (IIDA; BUARQUE, 2016). A utilização das novas máquinas informatizadas induziu a realização de diversas pesquisas na área de ergonomia, principalmente sobre apresentação e percepção de informações, memória e tomada de decisões. 
A ISO 9241(ABNT, 2002) é resultado dessa nova demanda criada pela interação com os sistemas informatizados, ela aborda a Ergonomia da interação humano-sistema, e a parte 210, o design centrado no usuário de sistemas interativos. Sua abordagem destaca os benefícios da eficácia e eficiência para o bem-estar humano, a satisfação do usuário, a acessibilidade e sustentabilidade e atua contra os possíveis efeitos indesejados do uso na saúde, segurança e performance. A ISO 9241 objetiva tornar disponível a informação para auxiliar os responsáveis por gerenciar design de hardware e software a re-projetar processos e identificar e planejar atividades de design centradas no usuário.

\section{3.}

\section{Princípios de usabilidade}

Para Cybis, Holtz e Faust (2010), a essência da usabilidade está no acordo entre interface, usuário, tarefa e ambiente. De acordo com os autores supracitados, a ergonomia está em sua origem, pois ela visa a proporcionar eficácia e eficiência, além do bem-estar e saúde do usuário por meio da adequabilidade do trabalho ao homem. Para eles, o objetivo da ergonomia é assegurar a adaptação de sistemas e dispositivos à maneira como o usuário pensa, comporta-se e trabalha, portanto, proporcionar-lhe usabilidade. Um produto ou serviço para ter usabilidade deve compreender a interação entre produtos, usuários, tarefas e ambiente de modo a produzir qualidade funcional, alcançar os objetivos e uso amigável (IIDA; BUARQUE, 2016).

A ISO 9241-11 (ABNT, 2002) define usabilidade como: "medida na qual um produto pode ser usado por usuários específicos com eficácia, eficiência e satisfação em um contexto específico de uso", onde:

- Eficácia: é a “acurácia e completude com as quais usuários alcançam objetivos específicos";

- Eficiência: são os "recursos gastos em relação à acurácia e à abrangência com as quais os usuários atingem objetivos"

- Satisfação: é a "ausência do desconforto e atitudes positivas para com o uso de um produto"; 
- Contexto de uso: define-se como os "usuários, tarefas, equipamento e o ambiente físico e social no qual um produto é usado".

Em suma:

Usabilidade é a capacidade de um produto ou sistema, em termos funcionaishumanos, de ser usado com facilidade e eficácia por um segmento específico de usuários, fornecendo-lhes treinamento e suporte específico, visando à execução de um elenco específico de tarefas, no contexto de cenário ambientais específicos. (SANTA ROSA; MORAES, 2012, p. 16).

Diversos autores elaboraram princípios, critérios e heurísticas de usabilidade a serem seguidos com o objetivo de projetar produtos visando à eficiência, à eficácia e à satisfação, ou seja, uma interação fácil e simples com o usuário. Algum destes autores são: Hansen (1971), Nielsen (1993), Molich e Nielsen (1990), Jordan (2001), Shneiderman e Plaisant (2005) e Bastien e Scapin (1997). Considerando que um dos problemas dessa pesquisa é: "até que ponto a usabilidade está sendo considerada como diretriz, levando em conta as características e singularidades do dispositivo?”, os princípios citados servirão posteriormente como base para os critérios de avaliação do teste de usabilidade.

Dentre os princípios de usabilidade elaborados pelos autores mencionados posteriormente, verificam-se redundâncias; Quaresma (2010) buscou determinar uma equivalência entre eles. Para facilitar o entendimento daqueles princípios será utilizada uma organização similar, conforme apresentado nos quadros a seguir (Quadros 2.1-2.4). A autora agrupou-os conforme seus objetivos específicos, de acordo com a categorização sugerida por Brangier e Barcenilla (2003). Os quatro objetivos específicos são:

- Facilitar a aprendizagem na primeira abordagem de um sistema;

- Facilitar a procura, a percepção, o reconhecimento e a compreensão das informações no sistema;

- Facilitar o controle da interação com o sistema;

- Considerar o contexto de uso do sistema e o tipo de usuário.

Vale ressaltar os princípios de usabilidade elaborados pelos autores Hansen (1971) e Shneiderman e Plaisant (2005) não enquadram-se no primeiro objetivo de usabilidade de Brangier e Barcenilla, (2003) e por isso não foram mencionados no Quadro 2.1. 
Objetivo 1: Facilitar a aprendizagem na primeira abordagem de um sistema

Este primeiro grupo de princípios (Quadro 2.1) enfatiza que o conhecimento necessário para utilizar novos produtos e sistemas deve estar de acordo com aquele adquirido previamente pelo usuário por meio da interação com produtos e sistemas de modo a facilitar a transferência de conhecimentos e minimizar a aprendizagem (BRANGIER; BARCENILLA, 2003). Estes princípios estão relacionados ao que o Jordan (2001) denomina de guessability (capacidade de adivinhar) e o Nielsen (1993) de learnability (capacidade de aprender), ambos dizem respeito ao momento do primeiro contato de um usuário com um sistema e como ele pode facilitar essa aprendizagem.

$\mathrm{Na}$ primeira interação com um produto o usuário busca deduzir como interagir por meio de associações e correspondências com outros produtos e situações cotidianas. Ao projetar, deve utilizar-se conhecimentos que o usuário já adquiriu utilizando sistemas similares ou diferentes. Com isso diminui-se a carga mental do usuário com novos aprendizados e evita-se a desistência de uso do produto (QUARESMA, 2010).

Essa noção de correspondência nos remete ao termo affordances, criado por J.J. (GIBSON, 1979) e popularizado por Donald Norman (NORMAN, DONALD A., 1990). Este autor explica que o termo refere-se às percepções e às reais propriedades de um objeto, as propriedades fundamentais que determinam como ele pode ser utilizado. Affordances dão pistas ao usuário de como um objeto deve ser utilizado ou manuseado, por exemplo: uma maçaneta indica que devemos virála. As boas correspondências, ou affordances, são aquelas que indicam explicitamente ao usuário a ação que deve ser feita, evitam explicações desnecessárias e diminuem sua carga cognitiva.

É importante organizar as informações de maneira coerente e familiar, seguindo o modelo mental do usuário, diminuindo a quantidade delas a serem memorizadas. A maneira como serão apresentadas impacta diretamente a sua interpretação e o seu uso (STIBEL, 2005). 


\begin{tabular}{|c|c|c|}
\hline NIELSEN (1993) & BASTIEN E SCAPIN (1997) & JORDAN (2001) \\
\hline \multirow[t]{3}{*}{$\begin{array}{l}\text { 2. Compatibilidade do sistema } \\
\text { com o mundo real O sistema } \\
\text { deve falar a linguagem do } \\
\text { usuário, com palavras, frases e } \\
\text { conceitos familiares ao usuário. } \\
\text { Seguir convenções do mundo } \\
\text { real, fazendo com que a } \\
\text { informação seja apresentada de } \\
\text { uma forma natural e em uma } \\
\text { ordem lógica. }\end{array}$} & $\begin{array}{l}\text { 8. Compatibilidade. Ela se refere } \\
\text { ao acordo que pode existir entre as } \\
\text { características dos usuários } \\
\text { (memoria, percepção, hábitos, } \\
\text { competências, idade, expectativas, } \\
\text { etc.) e as tarefa, de um lado, e a } \\
\text { organização de saídas, de entradas e } \\
\text { de dialogo de uma determinada } \\
\text { aplicação, de outro lado. Além } \\
\text { disso, a compatibilidade diz respeito } \\
\text { igualmente ao grau de similaridade } \\
\text { entre diversos ambientes ou } \\
\text { aplicações. }\end{array}$ & $\begin{array}{l}\text { 2. Compatibilidade. Projetar um } \\
\text { produto de forma que seu método } \\
\text { de operação seja compatível com } \\
\text { as expectativas dos usuários, } \\
\text { baseadas no seu conhecimento de } \\
\text { outros tipos de produtos no } \\
\text { 'mundo externo'; } \\
\text { 9. Transferência apropriada de } \\
\text { informações. Usar de forma } \\
\text { adequada a tecnologia desenvolvida } \\
\text { em outros contextos para aumentar } \\
\text { a usabilidade de um produto. }\end{array}$ \\
\hline & $\begin{array}{l}\text { 1. Condução. O conjunto de } \\
\text { meios disponíveis para } \\
\text { aconselhar, orientar, informar e } \\
\text { conduzir o usuário nas interações } \\
\text { com o computador (mensagens, } \\
\text { alarmes, rótulos, etc.), incluindo } \\
\text { os aspectos lexicais. }\end{array}$ & $\begin{array}{l}\text { 10. Transparência } \\
\text { (Explicitness). Projetar um } \\
\text { produto fornecendo indicações } \\
\text { que remetem [apresentem] } \\
\text { claramente as suas } \\
\text { funcionalidades e aos } \\
\text { procedimentos disponíveis. }\end{array}$ \\
\hline & $\begin{array}{l}\text { 1.1 Incentivo. Meios para o } \\
\text { usuário conhecer as ações } \\
\text { disponíveis, as alternativas, o } \\
\text { estado do contexto onde ele se } \\
\text { encontra na interação. }\end{array}$ & \\
\hline
\end{tabular}

Quadro 2.1 - Princípios relacionados ao objetivo de facilitar o aprendizado do sistema Fonte: Baseado em (QUARESMA, 2010).

Objetivo 2: Facilitar a busca, a percepção, o reconhecimento e a compreensão das informações no sistema

O segundo grupo de princípios (Quadro 2.2) está relacionado à forma em que as informações são apresentadas no produto, para facilitar a codificação e o armazenamento de dados para reduzir a carga de trabalho. Está dividido em 3 subcategorias:

- Princípios que oferecem recomendações sobre os aspectos da percepção. Têm como objetivo assegurar a legibilidade e a clareza visual das informações (tamanho mínimo da fonte, percepção de contrastes e de cores e a priorização e a hierarquização das informações);

- A segunda subcategoria refere-se à princípios que têm como objetivo a compreensão dos dados, dizem respeito aos significados dos códigos, termos e ícones. As informações apresentadas devem ser facilmente compreendidas pelos usuários. Propõem-se a garantir uma estruturação coerente das informações (homogeneidade, 
coerência interna da apresentação dos dados, agrupamento e distinção dos dados de acordo com seu formato e significado);

- A terceira subcategoria trata dos problemas associados à memória $\mathrm{e}$ à carga de trabalho. Estes princípios aconselham garantir: a brevidade; a concisão; diminuir a densidade informacional; o reconhecimento ao invés da recordação; e diminuir a demanda da memória de curto prazo, levando em conta recursos cognitivos e físicos dos usuários. A memória de curto prazo dos humanos é limitada em termos da capacidade de armazenamento de informações e necessita de recursos de apoio do produto.

Esta segunda categoria de princípios está intrinsicamente relacionada à arquitetura da informação (AI) (QUARESMA, 2010). Morville; Rosenfeld (2007) a definem como:

1. O design estrutural de ambientes de informação compartilhada;

2. A combinação de organização, rotulagem, busca e sistemas de navegação dentro sites e intranets;

3. A arte e a ciência de formar produtos de informação e experiências para apoiar a usabilidade e a findability (facilidade de encontrar); e

4. Uma disciplina emergente e uma comunidade de prática focada em trazer princípios de design e arquitetura para o âmbito digital.

Segundo Agner, (2007) a arquitetura da informação de um sítio pode ser apresentada em quatro sistemas interdependentes, os sistemas de organização, de navegação, de rotulação e de busca, definidos a seguir:

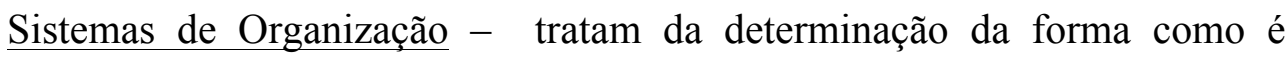
apresentada a organização e a categorização do conteúdo;

Sistemas de Rotulação - definem os signos verbais (terminologia) e visuais (icônicos) para cada elemento informativo e cada elemento de suporte à navegação do usuário;

Sistemas de Navegação - especificam formas de o usuário se transitar no espaço informacional; e

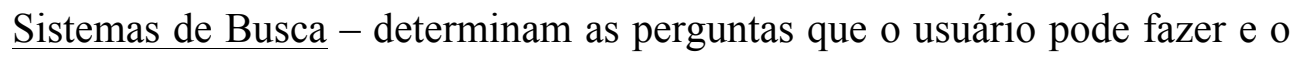
conjunto de respostas que irá obter ao executar uma busca no banco de dados (AGNER, 2007, p. 86). 


\begin{tabular}{|c|c|c|c|c|}
\hline HANSEN (1971) & NIELSEN (1993) & $\begin{array}{c}\text { BASTIEN e } \\
\text { SCAPIN (1997) }\end{array}$ & JORDAN (2001) & $\begin{array}{l}\text { SHNEIDERMANe } \\
\text { PLAISANT(2005) }\end{array}$ \\
\hline & & $\begin{array}{l}\text { 1.2 Agrupamento } \\
\text { / Distinção pelo } \\
\text { formato ou pela } \\
\text { localização. } \\
\text { Organização } \\
\text { visual dos itens de } \\
\text { informação, uns } \\
\text { em relação aos } \\
\text { outros. O } \\
\text { agrupamento } \\
\text { considera a } \\
\text { localização e o } \\
\text { formato para } \\
\text { indicar as relações } \\
\text { entre os diversos } \\
\text { itens } \\
\text { apresentados, e se } \\
\text { eles pertencem ou } \\
\text { não a uma mesma } \\
\text { classe de itens. }\end{array}$ & $\begin{array}{l}\text { 7. Clareza visual. } \\
\text { Projetar um produto } \\
\text { de tal maneira que a } \\
\text { informação } \\
\text { apresentada possa } \\
\text { ser lida fácil e } \\
\text { rapidamente sem } \\
\text { que ela leve à } \\
\text { confusão. } \\
\text { 8. Priorização de } \\
\text { funcionalidades e } \\
\text { de informação. } \\
\text { Projetar um produto } \\
\text { de modo que as } \\
\text { funcionalidades e as } \\
\text { informações mais } \\
\text { importantes estejam } \\
\text { facilmente } \\
\text { acessíveis ao } \\
\text { usuário. }\end{array}$ & \\
\hline & & $\begin{array}{l}\text { 1.4 Legibilidade. } \\
\text { Características } \\
\text { concretas da } \\
\text { apresentação das } \\
\text { informaços que } \\
\text { devem facilitar a } \\
\text { leitura (tipografia, } \\
\text { espaçamento, etc.). }\end{array}$ & & \\
\hline $\begin{array}{l}\text { Minimizar a } \\
\text { memorização. } \\
\text { Porque o usuário } \\
\text { esquece e o } \\
\text { computador deve } \\
\text { aumentar essa } \\
\text { memória. }\end{array}$ & $\begin{array}{l}\text { 6. Reconhecer ao } \\
\text { invés de } \\
\text { relembrar. Os } \\
\text { objetos, as ações e } \\
\text { as opções devem } \\
\text { ser visíveis. O } \\
\text { usuário não deve } \\
\text { ter que relembrar } \\
\text { informações } \\
\text { quando ele passa } \\
\text { de um estado de } \\
\text { interação para } \\
\text { outro. As } \\
\text { instruções para } \\
\text { usar o sistema } \\
\text { devem ser visíveis } \\
\text { ou facilmente } \\
\text { recuperáveis } \\
\text { quando o usuário } \\
\text { tiver necessidade } \\
\text { delas. }\end{array}$ & $\begin{array}{l}\text { 2. Carga de } \\
\text { Trabalho. Este } \\
\text { critério diz } \\
\text { respeito ao } \\
\text { conjunto de } \\
\text { elementos da } \\
\text { interface que têm } \\
\text { um papel na } \\
\text { redução da carga } \\
\text { perceptiva ou } \\
\text { cognitiva dos } \\
\text { usuários e no } \\
\text { aumento da } \\
\text { eficiência do } \\
\text { dialogo. }\end{array}$ & $\begin{array}{l}\text { 3. Considerar as } \\
\text { capacidades dos } \\
\text { usuários. Projetar } \\
\text { um produto de tal } \\
\text { maneira que seu } \\
\text { modo de uso } \\
\text { considere as } \\
\text { exigências da } \\
\text { tarefa e as } \\
\text { capacidades do } \\
\text { operador durante a } \\
\text { interação com o } \\
\text { produto. }\end{array}$ & $\begin{array}{l}\text { 8. Reduzir a carga } \\
\text { de trabalho da } \\
\text { memória a curto } \\
\text { prazo. A limitação } \\
\text { do processamento } \\
\text { humano de } \\
\text { informação na } \\
\text { memoria de curto } \\
\text { prazo exige que } \\
\text { displays sejam } \\
\text { simples, que suas } \\
\text { múltiplas paginas } \\
\text { sejam } \\
\text { consolidadas, que a } \\
\text { frequência de } \\
\text { movimentação de } \\
\text { janelas seja } \\
\text { reduzida e que um } \\
\text { tempo de } \\
\text { treinamento seja } \\
\text { instituído para } \\
\text { códigos, } \\
\text { memorizações e } \\
\text { sequência de ações. }\end{array}$ \\
\hline
\end{tabular}




\begin{tabular}{|c|c|c|c|c|}
\hline & $\begin{array}{l}\text { 8. Estética e } \\
\text { design } \\
\text { minimalista. Os } \\
\text { diálogos não } \\
\text { devem conter } \\
\text { informações que } \\
\text { não são } \\
\text { pertinentes para a } \\
\text { tarefa em curso ou } \\
\text { que são raramente } \\
\text { utilizadas. Cada } \\
\text { informação } \\
\text { suplementar pode } \\
\text { entrar em } \\
\text { competição com a } \\
\text { informação } \\
\text { pertinente e } \\
\text { reduzir a sua } \\
\text { visibilidade. }\end{array}$ & $\begin{array}{l}\text { 2.1 Brevidade. } \\
\text { Limitar o trabalho } \\
\text { de leitura e de } \\
\text { entrada de } \\
\text { informação. } \\
\text { Concisão para os } \\
\text { elementos } \\
\text { individuais de } \\
\text { entrada ou de } \\
\text { saída; e Ações } \\
\text { mínimas: limitar o } \\
\text { numero de ações } \\
\text { sucessivas } \\
\text { necessárias para } \\
\text { alcançar um } \\
\text { objetivo. } \\
\text { 2.2 Densidade } \\
\text { informacional: } \\
\text { reduzir ao } \\
\text { máximo a carga } \\
\text { informacional. }\end{array}$ & & \\
\hline 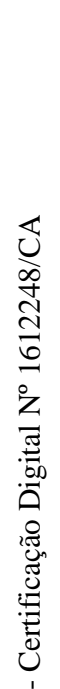 & $\begin{array}{l}\text { 4. Consistência e } \\
\text { padrões. Os } \\
\text { usuários não } \\
\text { devem se } \\
\text { perguntar se } \\
\text { palavras, ações ou } \\
\text { situações } \\
\text { diferentes } \\
\text { possuem o mesmo } \\
\text { significado. A um } \\
\text { objeto deve ser } \\
\text { associado um } \\
\text { significado, e } \\
\text { inversamente a } \\
\text { um significado } \\
\text { será associado um } \\
\text { objeto e um só. }\end{array}$ & $\begin{array}{l}\text { 6. } \\
\text { Homogeneidade / } \\
\text { Coerência. Este } \\
\text { critério refere-se à } \\
\text { maneira com a qual } \\
\text { as escolhas de } \\
\text { concepção da } \\
\text { interface (códigos, } \\
\text { denominações, } \\
\text { formatos, } \\
\text { procedimentos, } \\
\text { etc.) são } \\
\text { conservados para } \\
\text { contextos idênticos, } \\
\text { e são diferentes } \\
\text { para contextos } \\
\text { diferentes. }\end{array}$ & $\begin{array}{l}\text { 1. Consistência. } \\
\text { Projetar um } \\
\text { produto de forma } \\
\text { que as tarefas } \\
\text { similares sejam } \\
\text { executadas da } \\
\text { mesma maneira. } \\
\text { Isto diz respeito } \\
\text { tanto aos objetos } \\
\text { manipulados } \\
\text { quanto aos } \\
\text { procedimentos } \\
\text { utilizados. }\end{array}$ & $\begin{array}{l}\text { 1. Buscar a } \\
\text { consistência. } \\
\text { Propor sequências } \\
\text { de ações similares } \\
\text { para situações } \\
\text { semelhantes. } \\
\text { Utilizar a mesma } \\
\text { terminologia para } \\
\text { as mensagens } \\
\text { indicativas, os } \\
\text { menus e as telas } \\
\text { de ajuda. As } \\
\text { exceções, como a } \\
\text { confirmação de } \\
\text { uma ação de } \\
\text { deletar, ou a } \\
\text { entrada de uma } \\
\text { senha, devem ser } \\
\text { limitadas. }\end{array}$ \\
\hline 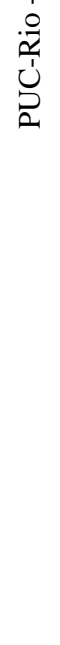 & & $\begin{array}{l}\text { 7. Significado dos } \\
\text { Códigos e } \\
\text { Denominações. } \\
\text { Este critério diz } \\
\text { respeito à } \\
\text { adequação entre o } \\
\text { objeto ou a } \\
\text { informação } \\
\text { apresentada ou } \\
\text { inserida, e sua } \\
\text { referência. Os } \\
\text { códigos e } \\
\text { denominações } \\
\text { "significativas" } \\
\text { dispõem de uma } \\
\text { relação semântica } \\
\text { forte com sua } \\
\text { referência. }\end{array}$ & & \\
\hline
\end{tabular}




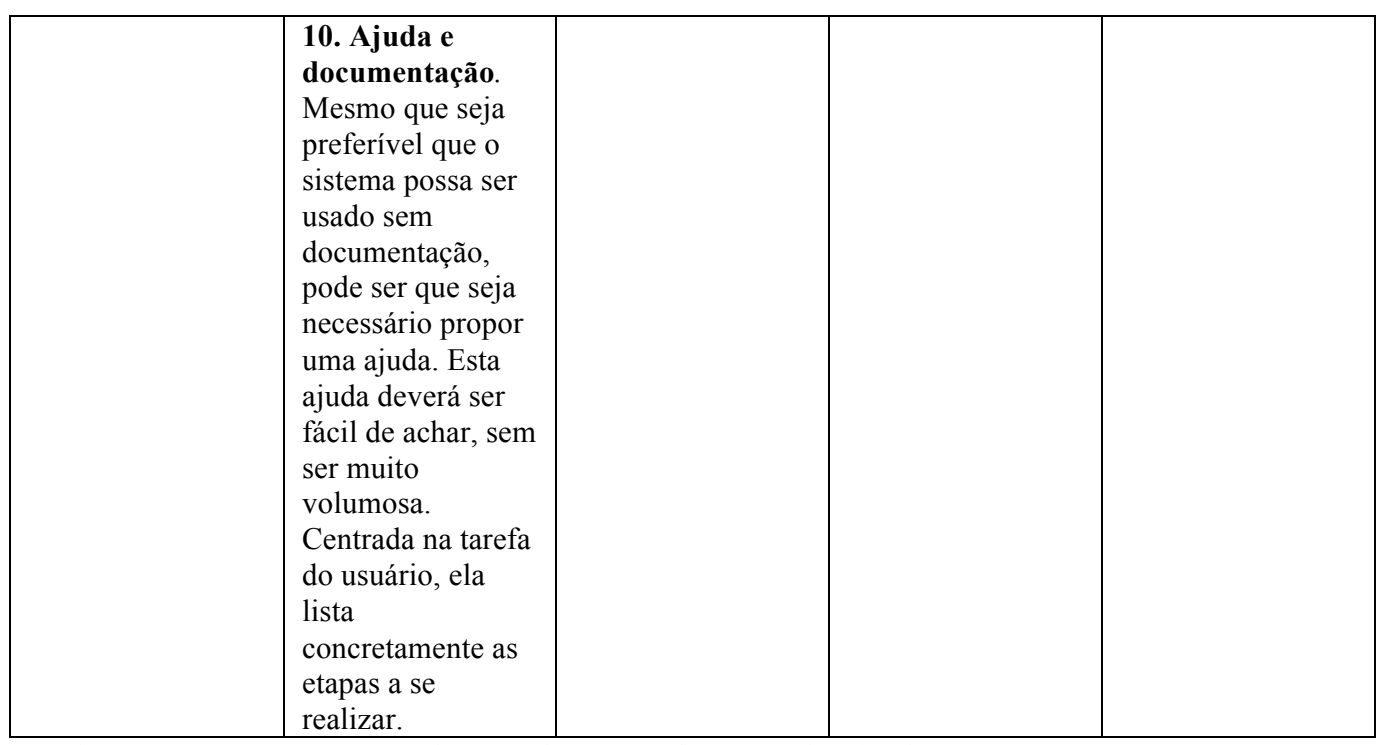

Quadro 2.2 - Princípios relacionados ao objetivo de facilitar a procura, a percepção, o reconhecimento e a compreensão das informações no sistema. Fonte: Baseado em (QUARESMA, 2010).

Objetivo 3: Facilitar o controle da interação com o sistema

O terceiro grupo de princípios (Tabela 2.3) ressalta a importância do usuário controlar as suas atividades. Isso significa ter a possibilidade de planejar antecipadamente a tarefa e ser capaz de:

- Antecipar resultados;

- Executar a tarefa;

- Controlar os resultados das ações;

- Compreender o estado do sistema; e

- Corrigir os erros.

Para que isto seja possível estes princípios tratam do decorrer da atividade normal e dos erros. No primeiro caso o produto deve:

- Simplificar a estrutura da tarefa;

- Fornecer informações que sejam referentes aos recursos e aos procedimentos disponíveis;

- Apresentar claramente as funcionalidade e as informações que são relevantes para cumprir a tarefa que está sendo executada; 
- Tornar as opções visíveis para informar ao usuário o estado em que encontra-se o produto e oferecer um retorno (feedback) informativo ao usuário;

- Oferecer atalhos para que os usuários mais experientes possam executar as tarefas com mais rapidez;

- Dar controle ao usuário, permitir que monitore o progresso da tarefa que está sendo executada; e

- Indicar ao usuário a finalização de uma tarefa ou sua interrupção.

Em caso de erros:

Zapt e Reason (1994 apud (BRANGIER; BARCENILLA, 2003) descrevem 3 fases do tratamento de erros: a ocorrência do erro, seu diagnóstico e recuperação. Os princípios de usabilidade que abordam a gestão de erros preveem o tratamento de cada uma dessas fases.

- O sistema deve proteger o usuário contra erros, limitando a quantidade de opções disponíveis e só tornar disponíveis as opções relevantes ao cumprimento da tarefa;

- Caso aqueles ocorram, o produto deve permitir que o usuário os diagnostique; e

- A verificação do erro não é suficiente, o usuário também deve ser capaz de recuperar-se dele. A qualidade da ajuda oferecida pelo produto é essencial para a realização desta esta terceira fase.

Um produto deve ser tolerante a erros, pois o usuário é falível, propenso ao esquecimento, sensível, tem paciência limitada e possui um estado de alerta flutuante. Ações que permitam reverter erros devem ser favorecidas.

Em suma, as recomendações descritas até agora são projetadas para fornecer ao usuário transparência quanto ao estado do produto, isso significa revelar o seu funcionamento e as oportunidades de ação. A consistência ou coerência interna, a consistência externa ou compatibilidade, o retorno imediato e adequado e a qualidade da mensagem contribuem para o usuário desenvolver um modelo mental adequado do produto. 


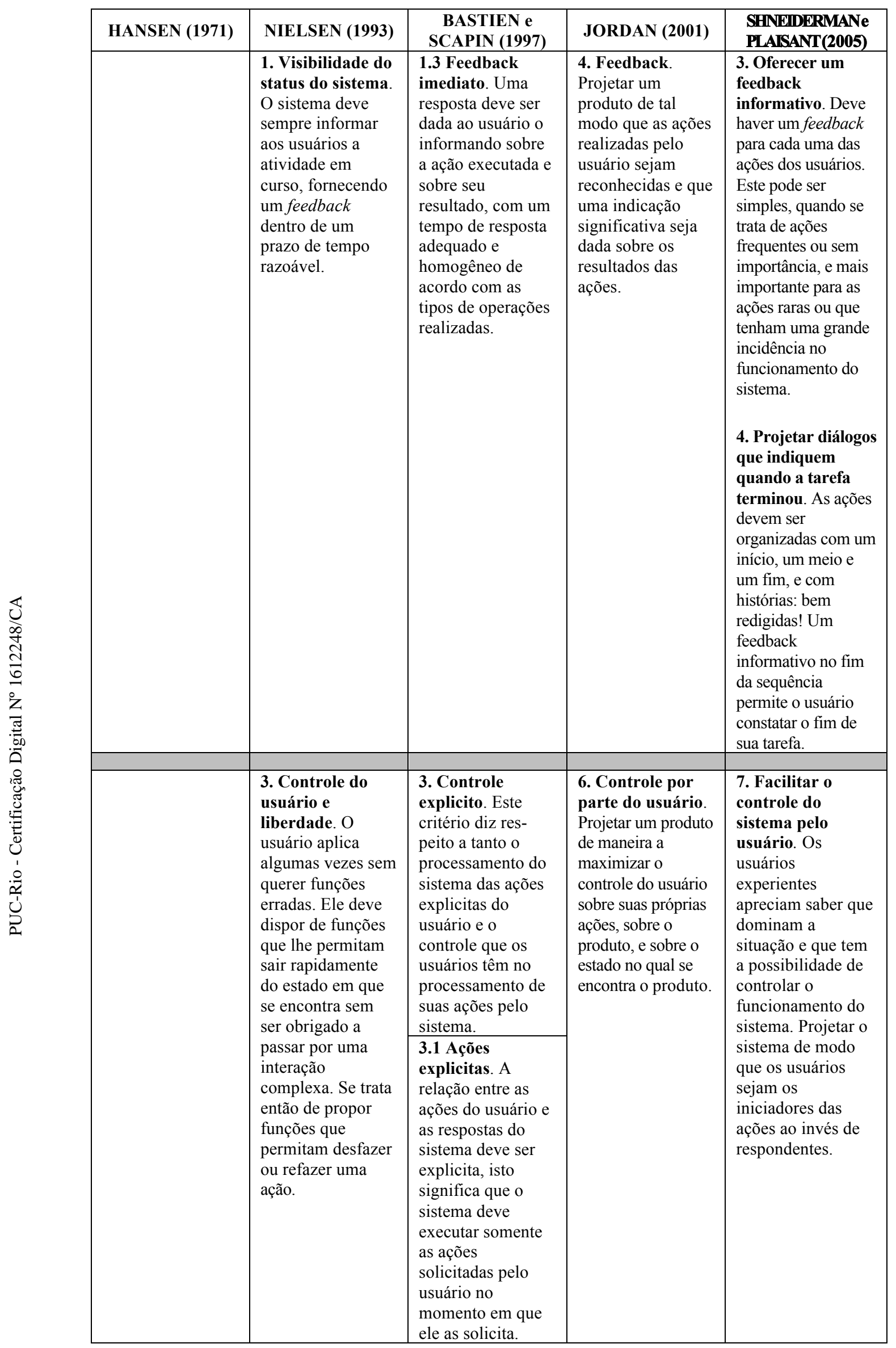




\begin{tabular}{|c|c|c|c|c|}
\hline & & $\begin{array}{l}\text { 3.2 Controle do } \\
\text { usuário. O usuário } \\
\text { deve sempre poder } \\
\text { controlar o } \\
\text { desenrolar dos } \\
\text { processamentos do } \\
\text { sistema. }\end{array}$ & & \\
\hline & & $\begin{array}{l}\text { 5. Gestão de erros. } \\
\text { Este critério diz } \\
\text { respeito a todos os } \\
\text { meios disponíveis } \\
\text { para evitar ou } \\
\text { reduzir os erros e } \\
\text { corrigi-los quando } \\
\text { eles ocorrerem. Os } \\
\text { erros são } \\
\text { considerados como } \\
\text { entrada de dados } \\
\text { incorretas, formato } \\
\text { invalido para } \\
\text { entrada de dados, } \\
\text { entrada de } \\
\text { comando com uma } \\
\text { sintaxe incorreta, } \\
\text { etc. }\end{array}$ & & \\
\hline $\begin{array}{l}\text { 4. Projetar para } \\
\text { erros. O usuário } \\
\text { deve ser protegido } \\
\text { de erros } \\
\text { provenientes do } \\
\text { sistema ou } \\
\text { daqueles que ele } \\
\text { próprio comete. O } \\
\text { sistema deve ser } \\
\text { projetado de } \\
\text { maneira a evitar } \\
\text { erros catastróficos } \\
\text { e permitir a } \\
\text { recuperação do } \\
\text { maior número } \\
\text { possível. }\end{array}$ & $\begin{array}{l}\text { 5. Prevenção de } \\
\text { erros. É preferível } \\
\text { projetar um } \\
\text { produto que evite } \\
\text { que o usuário } \\
\text { cometa erros, do } \\
\text { que apresentar } \\
\text { boas mensagens de } \\
\text { erro. }\end{array}$ & $\begin{array}{l}\text { 5.1 Proteção } \\
\text { contra os erros. } \\
\text { Refere-se aos } \\
\text { meios disponíveis } \\
\text { para detectar e } \\
\text { prevenir: os erros } \\
\text { de entrada de } \\
\text { dados, os erros de } \\
\text { comandos, ou } \\
\text { ações com } \\
\text { consequências } \\
\text { destrutivas. }\end{array}$ & \multirow[t]{3}{*}{$\begin{array}{l}\text { 5. Prevenção e } \\
\text { recuperação de } \\
\text { erros. Projetar um } \\
\text { produto de tal } \\
\text { modo que os } \\
\text { possíveis erros por } \\
\text { parte do usuário } \\
\text { sejam } \\
\text { minimizados, e se } \\
\text { os erros ocorrem, } \\
\text { que seja possível } \\
\text { recuperá-los } \\
\text { rápido e } \\
\text { facilmente. }\end{array}$} & \multirow[t]{2}{*}{$\begin{array}{l}\text { 5. Fornecer } \\
\text { prevenção e } \\
\text { manipulação } \\
\text { simples de erros. } \\
\text { Deve-se propor ao } \\
\text { usuários } \\
\text { mecanismos } \\
\text { simples para } \\
\text { corrigir os erros, } \\
\text { quando ele utiliza } \\
\text { comandos errados } \\
\text { ou que chegam a } \\
\text { resultados } \\
\text { incompreensíveis. }\end{array}$} \\
\hline & \multirow{2}{*}{$\begin{array}{l}\text { 9. Ajudar o } \\
\text { usuário a } \\
\text { reconhecer, } \\
\text { diagnosticar e } \\
\text { recuperar-se dos } \\
\text { erros. As } \\
\text { mensagens de } \\
\text { erros devem ser } \\
\text { redigidas em } \\
\text { linguagem } \\
\text { natural/simples, } \\
\text { evitando código } \\
\text { obscuros. Trata-se } \\
\text { de explicar os } \\
\text { problemas } \\
\text { precisamente e } \\
\text { sugerir uma } \\
\text { solução } \\
\text { construtiva. }\end{array}$} & $\begin{array}{l}\text { 5.2 Qualidade das } \\
\text { mensagens de } \\
\text { erro. Refere-se à } \\
\text { expressão e ao } \\
\text { conteúdo das } \\
\text { mensagens de erro: } \\
\text { sua pertinência, } \\
\text { sua facilidade de } \\
\text { leitura, sua } \\
\text { precisão quanto a } \\
\text { natureza dos erros, } \\
\text { e a indicação das } \\
\text { ações de correção. }\end{array}$ & & \\
\hline & & $\begin{array}{l}\text { 5.3 Correção dos } \\
\text { erros. Refere-se } \\
\text { ao(s) meios } \\
\text { disponíveis ao } \\
\text { usuário para } \\
\text { corrigir } \\
\text { imediatamente } \\
\text { seus erros. }\end{array}$ & & $\begin{array}{l}\text { 6. Propor } \\
\text { possibilidades } \\
\text { fáceis de desfazer } \\
\text { as ações. As ações } \\
\text { devem ser } \\
\text { reversíveis. Esta } \\
\text { diminui a } \\
\text { ansiedade pois o } \\
\text { usuário sabe que } \\
\text { ele pode recuperar- } \\
\text { se de erros } \\
\text { possíveis. Ela }\end{array}$ \\
\hline
\end{tabular}




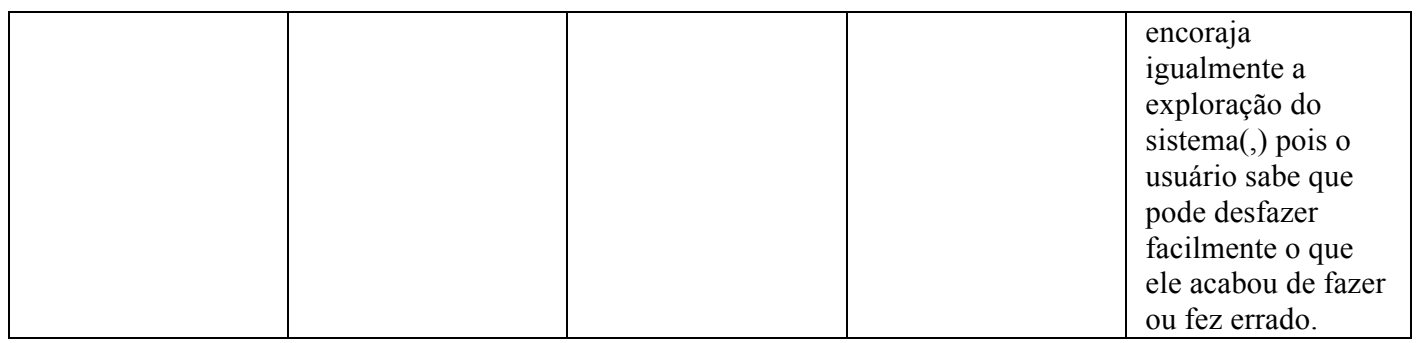

Quadro 2.3 - Princípios relacionados ao objetivo de facilitar o controle da interação com o sistema. Fonte: Baseado em (QUARESMA, 2010).

Objetivo 4: Considerar o contexto de uso do sistema e o tipo de usuário

$\mathrm{O}$ último grupo de recomendações (Quadro 2.4) está relacionado à flexibilidade ou à adaptabilidade dos dispositivos. Esta flexibilidade é a capacidade do dispositivo de ser adaptado ou de adaptar-se às necessidades do usuário, ela pode ser alcançada, oferecendo ao usuário:

- a capacidade de executar uma tarefa de diversas formas de acordo com a tarefa ou com o contexto de uso;

- possibilidade de personalizar ou individualizar ações com base na sua experiência de uso ou nas suas exigências, oferecendo atalhos, aos usuários mais experientes, por exemplo.

\begin{tabular}{|c|c|c|c|c|}
\hline HANSEN (1971) & NIELSEN (1993) & $\begin{array}{c}\text { BASTIEN e } \\
\text { SCAPIN (1997) } \\
\end{array}$ & JORDAN (2001) & $\begin{array}{l}\text { SHNEIDERMANe } \\
\text { PLAISANT(2005) }\end{array}$ \\
\hline \multirow[t]{2}{*}{$\begin{array}{l}\text { 3. Otimizar } \\
\text { operações. O } \\
\text { sistema deve ser o } \\
\text { mais discreto } \\
\text { possível, uma } \\
\text { ferramenta para } \\
\text { ser manipulada } \\
\text { quase sem esforço } \\
\text { consciente. }\end{array}$} & \multirow{3}{*}{$\begin{array}{l}\text { 7. Flexibilidade e } \\
\text { eficiência de uso. } \\
\text { Os aceleradores ou } \\
\text { os atalhos - } \\
\text { invisíveis aos } \\
\text { usuários } \\
\text { inexperientes - } \\
\text { podem facilitar o } \\
\text { uso de indivíduos } \\
\text { experientes. O } \\
\text { sistema deve } \\
\text { poder adaptar-se } \\
\text { tão bem ao usuário } \\
\text { experiente quanto } \\
\text { ao usuário } \\
\text { iniciante. Permitir } \\
\text { também ao usuário } \\
\text { personalizar ou } \\
\text { padronizar as } \\
\text { ações que ele } \\
\text { executa com mais } \\
\text { frequência. }\end{array}$} & $\begin{array}{l}4 . \\
\text { Adaptabilidade. } \\
\text { A adaptabilidade } \\
\text { de um sistema diz } \\
\text { respeito a sua } \\
\text { capacidade de } \\
\text { reagir de acordo } \\
\text { com o contexto, e } \\
\text { de acordo com as } \\
\text { necessidades e } \\
\text { preferências dos } \\
\text { usuários. }\end{array}$ & & \multirow{3}{*}{$\begin{array}{l}\text { 2. Permitir que os } \\
\text { usuários } \\
\text { frequentes usem } \\
\text { atalhos. Os } \\
\text { usuários } \\
\text { experientes } \\
\text { buscam por } \\
\text { tempos de resposta } \\
\text { curtos do sistema. } \\
\text { Por outro lado, } \\
\text { mesmo se os } \\
\text { usuários iniciantes } \\
\text { passam mais } \\
\text { tempo a explorar o } \\
\text { conteúdo da tela, } \\
\text { eles tem portanto a } \\
\text { possibilidade de } \\
\text { responder a seus } \\
\text { ritmos. Como } \\
\text { consequência, é } \\
\text { preferível ter } \\
\text { sistemas que } \\
\text { funcionam o mais } \\
\text { rápido possível. }\end{array}$} \\
\hline & & $\begin{array}{l}\text { 4.1 Flexibilidade. } \\
\text { Refere-se aos } \\
\text { meios disponíveis } \\
\text { ao usuário para } \\
\text { personalizar sua } \\
\text { interface de } \\
\text { maneira a } \\
\text { considerar suas } \\
\text { estratégias de } \\
\text { trabalho e/ou seus } \\
\text { hábitos e as } \\
\text { exigências de suas } \\
\text { tarefas. }\end{array}$ & & \\
\hline $\begin{array}{l}\text { 1. Conhecer o } \\
\text { usuário. O } \\
\text { designer do } \\
\text { sistema deve }\end{array}$ & & $\begin{array}{l}\text { 4.2 Consideração } \\
\text { da experiência do } \\
\text { usuário. Refere-se } \\
\text { aos meios }\end{array}$ & & \\
\hline
\end{tabular}




\begin{tabular}{|l|l|l|l|}
\hline tentar construir um & disponíveis para & & \\
perfil do usuário & considerar o nível & & \\
para quem está & de experiência do & & \\
projetando & usuário & \\
& (experientes, & & \\
& novatos e & & \\
& intermitentes). & & \\
\hline
\end{tabular}

Quadro 2.4 - Princípios relacionados ao objetivo de considerar o contexto de uso do sistema e o tipo de usuário. Fonte: Baseado em (QUARESMA, 2010).

Shneiderman e Plaisant (2005) advertem que os princípios de Shneiderman, devem ser interpretados, refinados e adaptados para cada situação. Estes princípios têm limitações, mas proporcionam um bom ponto de partida para avaliar a usabilidade de dispositivos móveis, desktop e web designers. Tais princípios concentram-se em aumentar a produtividade dos usuários, fornecendolhes procedimentos simplificados, a gerar-lhes um aumento no sentimento de competência, domínio e controle do sistema. Pode dizer-se que a advertência dos autores mencionados acima aplica-se aos demais princípios apresentados neste capítulo.

Os autores supracitados têm em mente preocupações comuns: adaptar às interfaces e os sistemas às necessidades do usuário. Dar-lhe o controle sobre o sistema, mantendo o usuário informado sobre seu status e oferecendo formas de evitar-se erros que impactem na realização de tarefas com eficiência e eficácia. Caso ocorram erros, tornar disponíveis meios de recuperação sem danos à tarefa. Os princípios visam ao bem-estar, não apenas físico, mas também cognitivo e perceptivo dos usuários. A interface do sistema deve ser fácil de aprender, falar a língua do usuário e consistente.

\section{4.}

\section{Experiência do Usuário (UX - User Experience)}

A noção de experiência é algo inerente à nossa existência, envolve tudo aquilo que é vivido pessoalmente. A experiência do usuário, por sua vez, difere da experiência pessoal no sentido de referir-se explicitamente às experiências derivadas de encontros com sistemas ${ }^{2}$ (ROTO et al., 2010).

\footnotetext{
${ }^{2}$ Sistema pode ser um produto, serviço ou artefatos - separadamente ou combinados - que uma pessoa interage por meio de uma interface do usuário.
} 
À medida que o uso de produtos complexos e que o uso da World Wide Web (Rede Mundial de Computadores) tornaram-se populares, houve uma conscientização crescente da importância das reações subjetivas e da experiência emocional do usuário decorrente dessas interações. Isso levou alguns autores a restringir a usabilidade aos aspectos pragmáticos de um produto (BEVAN; CARTER; HARKER, 2015). Porém, Norman (2004) esclarece que a emoção e a cognição estão intimamente ligados; a usabilidade é de suma importância, mas sem prazer, diversão, ansiedade, a vida do ser humano torna-se incompleta. Para compreender a interação do usuário com um produto é necessário também avaliar sua experiência. O termo experiência do usuário é relativamente novo e foi cunhado por Donald Norman no início da década dos 1990, quando trabalhava na Apple, empresa com matriz nos Estados Unidos da América (AGNI, 2015).

$\mathrm{Eu}$ inventei o termo porque achava que a interface humana e a usabilidade eram muito restritas. Queria abordar todos os aspectos da experiência de uma pessoa com o sistema incluindo o design industrial gráfico, a interface, a interação física e manual. Desde então o termo espalhou-se largamente, tanto que está começando a perder o seu significado (NORMAN, DON; MERHOLZ, 2007).

A ISO-9241-210 define a experiência do usuário, tradução do termo em inglês, User Experience - UX, como “as percepções e respostas dos usuários resultantes do uso e/ou antecipação do uso de um produto, sistema ou serviço". A norma também esclarece que a experiência do usuário inclui todas as emoções, crenças, preferencias, percepções, respostas físicas e psicológicas, comportamentos e realizações que ocorram antes, durante e após o uso. Além disso, a experiência do usuário é uma consequência da imagem da marca, da apresentação, da funcionalidade, da performance do sistema, do comportamento interativo e das capacidades de assistência do sistema interativo, o estado interno e físico do usuário, resultando de experiência anteriores, atitudes, habilidade e personalidade e do contexto de uso.

Kuniavsky (2010) define a experiência do usuário como o conjunto de percepções do usuário final ao interagir com um produto ou serviço. Essas percepções incluem eficácia, eficiência e a satisfação (usabilidade), além da qualidade do relacionamento com a entidade responsável pelo produto ou serviço. A usabilidade, por sua vez, é um conceito bem estabelecido, profissionais e estudiosos de experiência do usuário ainda discordam sobre alguns pontos; no 
entanto, compreendem que seja dinâmica, dependente do contexto de uso, subjetiva e seja uma pré-condição para a usabilidade (ROTO et al., 2010).

Distinguir o que é a interface do usuário, a usabilidade e a experiência do usuário (Figura 2.1) é essencial para estabelecer as diferenças entre os termos. A usabilidade é um atributo de qualidade da interface do usuário, determina a facilidade de uso e de aprendizagem do sistema, se ele é eficaz, eficiente e satisfatório e é medida durante a interação com o produto. A experiência do usuário abrange todos os aspectos da interação do usuário final com a empresa, seus serviços e produtos (NORMAN, DONALD A.; NIELSEN, [S.d.]). A experiência do usuário não é a mesma coisa que a usabilidade; porém, a forma como a usabilidade é percebida pelo usuário, contribui com a experiência do usuário como um todo (MOCZARNY; DE VILLERS; VAN BILJON, 2012; ROTO et al., 2010).

ANTES DE QUALQUER USO expectativa de uso do produto "uso antecipado"

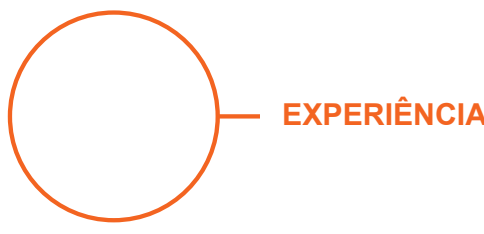

O processo de compra nem sempre é racional, ele pode envolver questões subjetivas culturais e emocionais (JEDDI et al., 2013), não só envolve valores relacionados ao cumprimento de tarefas, os pragmáticos, mas também valores hedônicos por meio de respostas que são evocadas durante essa experiência (BABIN; DARDEN; GRIFFIN, 1994). Portanto, deve-se considerar não somente os aspectos pragmáticos mas também os hedônicos resultantes deste processo. No entanto, vale ressaltar, que não é possível projetar uma experiência, somente em função dela, designers podem criar possibilidades mas não certezas. Afirmar que 
um grupo de recomendações sempre produzirá determinadas emoções, pode ser prometer mais do que poderá ser cumprido (HASSENZAHL, 2004).

O prazer que os produtos (pleasure with products) podem proporcionar são os benefícios emocionais, hedônicos e pragmáticos associados a eles (JORDAN, 2000) e diante disso sugere categorizar-se a qualidade de produtos em:

Pragmática (utilitário): refere-se à habilidade percebida do produto em atingir metas de fazer (HASSENZAHL, 2007).

Hedônica: refere-se à habilidade percebida em dar suporte ao usuário em atingir metas de ser ou estar. A qualidade hedônica pode ser dividida em três subcategorias: identificação, estimulação e evocação. Hassenzahl (2007) explica que identificação está relacionada à comunicação de identidade entre grupos relevantes, enquanto a estimulação estaria ligada à novidade, mudança e crescimento pessoal. Por fim, a evocação incluiria aspectos ligados a lembranças provocadas e experiências simbólicas de usuário.
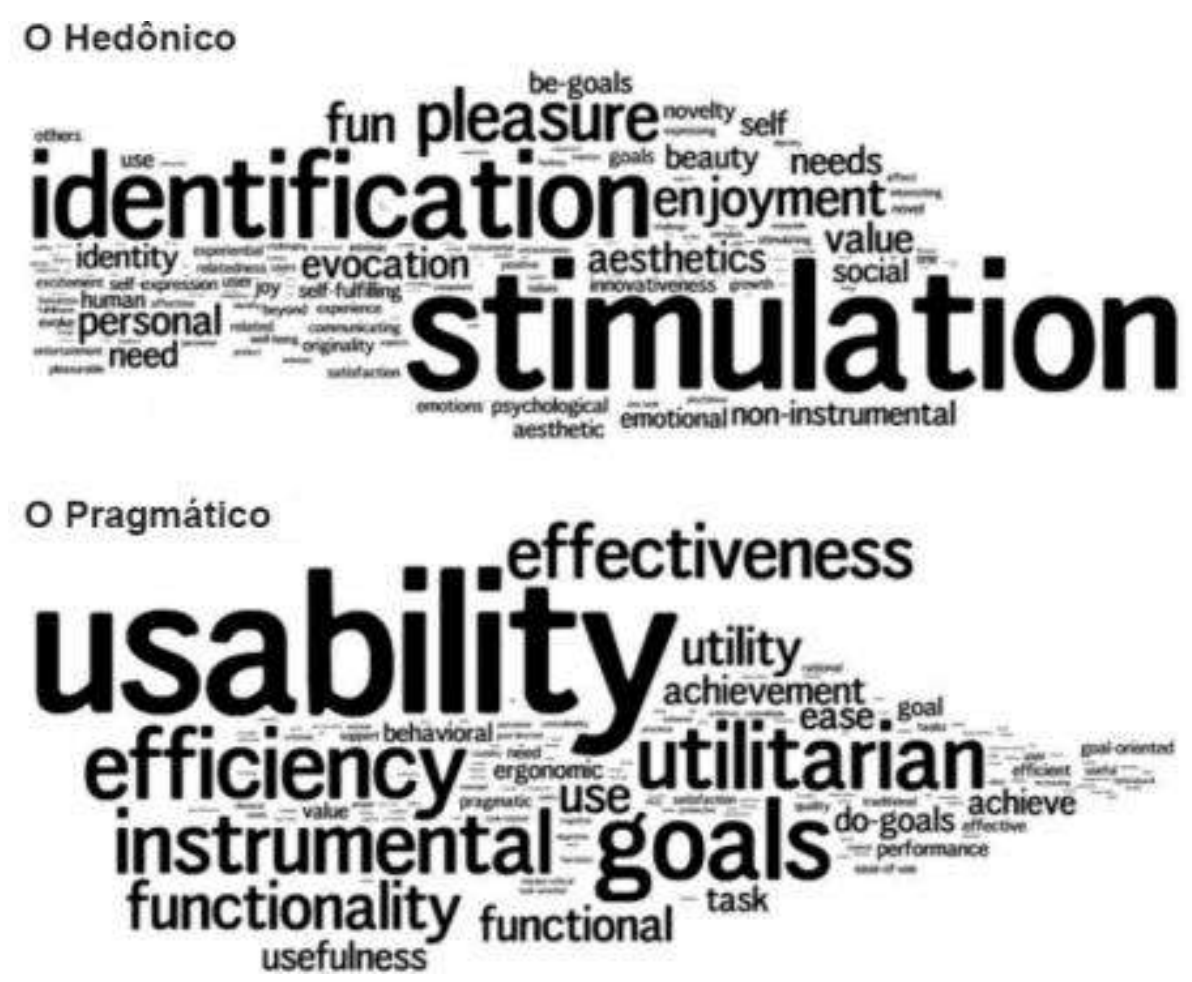

Figura 2.2: Palavras-chaves relacionadas com a qualidade hedônica (topo) e qualidades pragmáticas (embaixo). Obs.: o tamanho da fonte representa a frequência, visualização criado por wordle.net Fonte: (HASSENZAHL; DIEFENBACH; GÖRITZ, 2010, p. 307).

Conclui-se que a usabilidade pode ser uma medida da qualidade pragmática de um produto, pois diz respeito ao cumprimento de tarefas e objetivos, que por 
sua vez estão ligados ao comportamento utilitário do usuário (BABIN; DARDEN; GRIFFIN, 1994). Enquanto a experiência do usuário está relacionada à qualidade hedônica de um produto, pois é associada "à aspectos estéticos, intangíveis e subjetivos do consumo" (HIRSCHMAN; HOLBROOK, 1982). A usabilidade trata a satisfação do usuário, como "ausência de conforto" não avalia, nem mede as emoções causadas por uma interação. As abordagens baseadas apenas na usabilidade são limitadas pois tendem a ter uma visão dos produtos como ferramentas com as quais os usuários efetuam tarefas. Contudo, produtos não são meramente ferramentas: alguns deles podem ser considerados como "objetos vivos" com os quais as pessoas têm relacionamentos. Os produtos podem tornar as pessoas felizes ou irritadas, orgulhosas ou envergonhadas, seguras ou ansiosas. (JORDAN, 2000). Um produto pode ter uma usabilidade perfeita mas mesmo assim não proporcionar uma experiência do usuário positiva (NORMAN, DONALD A.; NIELSEN, [S.d.]).

Alguns autores defendem a utilização da usabilidade para medir aspectos subjetivos da interação do usuário com um produto (BEVAN; CARTER; HARKER, 2015; JORDAN, 2000). Para essa pesquisa a usabilidade será tratada como um aspecto pragmático da interação humano-computador sendo um dos fatores que impactam positiva ou negativamente a experiência do usuário.

\section{5 .}

\section{Usabilidade desktop versus a usabilidade móvel}

No item 2.3 deste capítulo apresentaram-se princípios cujos objetivos são proporcionar usabilidade a produtos; porém, foram desenvolvidos quando os dispositivos móveis não eram tão populares, nem possuíam uma tecnologia tão desenvolvida quanto atualmente. Esse conjunto de princípios, pode e deve ser utilizado tanto para desktops quanto para dispositivos móveis. Posteriormente, alguns autores escreveram diretrizes específicas para a categoria móvel.

A seguir, serão discutidos alguns critérios que devem ser considerados ao projetar-se para dispositivos móveis, para essa pesquisa foi dada ênfase na categoria smartphones. 
A experiência desktop, (resultado da interação com um computador de mesa), não é igual a experiência móvel (resultado da interação com um dispositivo móvel (MENDOZA, 2014).

Se tudo a respeito dos dispositivos móveis é diferente, o tamanho de tela, a conexão com a internet, o tamanho do dispositivo e a abordagem do usuário ao utilizar um website, então por que utilizar a experiência de desktop existente e transpô-la sem modificá-la? (MENDOZA, 2014, p. 11).

A definição da ISO-9241 trata a usabilidade não como uma qualidade isolada de um produto, mas o seu diálogo com o usuário, o objetivo da tarefa que aquele está executando e o ambiente onde esse produto está inserido (CHAMMAS; QUARESMA; MONT’ALVÃO, 2013; JORDAN, 2001). Portanto, tratando-se de um dispositivo móvel o contexto de uso de um produto é de suma importância em razão de sua natureza portátil. A experiência em um smartphone não se equipara à experiência em um desktop: para propor-se uma boa experiência ao usuário on-line deve considerar-se tanto a usabilidade móvel quanto a fixa (CYBIS; HOLTZ; FAUST, 2010). São realidades díspares de uso. Ao interagir com um desktop, o usuário normalmente está com a sua atenção disponível a dedicar-se à essa tarefa. Contudo, ao utilizar um smartphone ele não está com sua atenção 100\% voltada para o dispositivo (MENDOZA, 2014). Ao projetar sítios para um dispositivo móvel, o designer deve considerar a diversidade de lugares e de situações de uso, a título de exemplo: $84 \%$ dos indivíduos usam seus smartphones em casa, 74\% enquanto esperam em uma fila, $69 \%$ enquanto fazem compras, $64 \%$ enquanto assistem à televisão e $47 \%$ no trajeto entre suas casas e o trabalho (WROBLEWSKI, 2011). As situações de uso mencionadas reforçam a ideia de que há uma atenção parcial do usuário ao interagir com um smartphone. Conhecer o usuário é essencial, sendo este o primeiro princípio de engenharia do usuário de Hansen (1971) e, além disso, saber quais são as ações mais comuns executadas em cada sítio (LEVY, 2015). A experiência móvel, comparada a com o desktop, deve tornar disponível de maneira mais direta e fácil o acesso a essas tarefas. 


\subsection{1.}

\section{O impacto do tamanho da tela na usabilidade}

Para que um smartphone seja fácil de carregar ele precisa ser pequeno e, portanto, sua interface menor, em média, é $80 \%$ menor do que a tela de um desktop (WROBLEWSKI, 2011). No levantamento das diretrizes de usabilidade móvel, todos os autores estudados abordam a questão da falta de espaço na tela dos smartphones. Nielsen e Budiu (2014) apontam que os usuários móveis enfrentam 4 principais barreiras à usabilidade, entre elas estão as telas pequenas. Os autores acima citados apontam a dificuldade de encontrar espaço para múltiplas janelas ou espaço para outras soluções de interface que suportem comportamentos avançados, como a pesquisa comparativa de produtos. Mendoza Mendoza (2014) e Wroblewski (2011) alertam que não cabe todo o conteúdo em uma tela pequena; consequentemente deve eliminar-se o de valor questionável e manter-se somente aquilo que é essencial ao usuário.

É muito mais difícil entender informações complexas quando se está lendo em um pequeno visor. A falta de espaço significa menos opções visíveis, os usuários exploram mais a interface, rolando a tela para ir a outras partes do conteúdo em vez de simplesmente verem o conteúdo de relance e, deste modo, demanda-se mais de sua memória de curto prazo para o entendimento das informações (NIELSEN; BUDIU, 2014). Os autores citados na parte 2.3.1 desse capítulo (Tabela 2.2), referem-se à necessidade de uma baixa carga de memorização. Em razão disto o sistema deve apresentar uma interface simples, sem sobrecarga cognitiva.

À medida que o usuário vai rolando as telas, mais informações precisam ser armazenadas em sua memória de trabalho (de capacidade reduzida), pois o que ele não está mais vendo precisa ser lembrado para que a informação possa lhe fazer sentido. Quanto menor a tela, maior a carga cognitiva. (CYBIS; HOLTZ; FAUST, 2010, p. 237)

Tanto o desktop quanto o smartphone devem conter interfaces simples que auxiliem a memorização. Para isso requerem uma boa estrutura e equilíbrio para relacionar elementos e facilitar a apreensão subjetiva das telas, sem exigir esforço. 


\subsection{2.}

\section{Diferenças na alimentação de informações no desktop/laptop e no smartphone}

Os smartphones, em contraste com os desktops, não contam com a precisão do mouse. Telas sensíveis ao toque são operadas por gestos, tornando a alimentação de informações e o "clique"3 em botões mais difícil. Há uma tendência a diminuir-se as áreas de toque na tela do smartphone, quando essas deveriam ser maiores para evitar o que Nielsen e Budiu (2014) chamam de “síndrome do dedo gordo". Por causa das minúsculas áreas para o toque, o usuário acaba cometendo erros ao esbarrar em outras igualmente sensíveis. Essa dificuldade, consequentemente, provoca nos usuários uma percepção negativa em relação ao uso de smartphones como meio de acesso a sítios de e-commerce (OZOK; WEI, 2010).

A quantidade de recursos deve ser limitada aos de maior importância, os layouts precisam ser mais limpos e os botões e áreas de toque maiores. Essas medidas vão ao encontro às regras de ouro de Shneiderman e Plaisant (2005) e aos princípios de usabilidade dos demais autores citados na parte 2.3 deste capítulo. Eles defendem que a interface não pode contribuir para que o usuário cometa erros graves e, caso aconteçam, devem haver mecanismos que os tratem, os corrijam na medida do possível e, caso não seja possível, enderece o usuário para a adoção de uma solução.

Saffer (2008) sugere dois modos de contornar a questão do tamanho das áreas de toque; um é criar uma área "invisível" ao redor, denominada pelo autor de "ponta do iceberg" (Figura 2.3), alusão à sua pequena parte visível. A outra, é utilizar alvos adaptáveis, estes criados algoritmicamente para prever o próximo passo do usuário. Muito utilizados em teclados virtuais, prevendo a próxima letra a ser digitada e desta maneira isolando-a para evitar erros. Hansen (1971) já defendia a necessidade de projetar-se para os erros, protegendo o usuário de graves consequências e a permitir a recuperação daqueles (Quadro 2.3).

3 O equivalente de um "clique" em um dispositivo com a tela sensível ao toque é "tap" - bater levemente - por ter uma tradução pouco difundida a autora decidiu adotar "clique" também para essa categoria de dispositivos. 


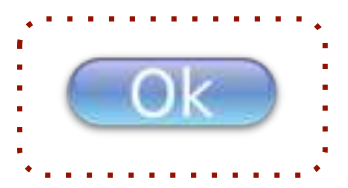

Figura 2.3 - Área "invisível" em torno do alvo de toque. Fonte: Adaptado de (SAFFER, 2008, p. 43).

A largura de um dedo limita a densidade de itens na tela. Se esses itens estão muito próximos, o usuário não será capaz de escolher nenhum (WROBLEWSKI, 2011).

\begin{tabular}{|l|l|l|}
\hline & \multicolumn{1}{|c|}{ Mouse } & \multicolumn{1}{|c|}{ Dedo } \\
\hline Precisão & Alta & Baixa \\
\hline Número de pontos especificado & 1 & $\begin{array}{l}\text { Normalmente 1;2 a 3 com } \\
\text { multitoques }\end{array}$ \\
\hline Número de controles & $\begin{array}{l}\text { 3: botões esquerdo/direito, roda de } \\
\text { rolagem }\end{array}$ & 1 \\
\hline Tempo de deslocamento? & Sim & Não \\
\hline Estados do sinal & $\begin{array}{l}\text { Flutuação, mouse para baixo, } \\
\text { mouse para cima }\end{array}$ & Dedo para baixo, dedo para cima \\
\hline Movimentos acelerados & Sim & Não \\
\hline $\begin{array}{l}\text { Adequado para uso com } \\
\text { monitores grandes de desktop } \\
\text { (30" ou mais) }\end{array}$ & Sim, devido à aceleração & Não, devido à fadiga do braço \\
\hline Ponteiro/cursos visível & Sim & Não \\
\hline Obscurece a visão da tela & $\begin{array}{l}\text { Não, possibilitando um feedback } \\
\text { visual contínuo }\end{array}$ & Sim \\
\hline $\begin{array}{l}\text { Adequado para dispositivo } \\
\text { móvel }\end{array}$ & Não & Sim; nada extra para carregar \\
\hline $\begin{array}{l}\text { Engajamento direto com a tela e } \\
\text { "divertido" de usar }\end{array}$ & $\begin{array}{l}\text { Não; é um dispositivo indireto de } \\
\text { apontamento }\end{array}$ & Sim \\
\hline Suporte e acessibilidade & Sim & Não \\
\hline Fácil de aprender & Razoavelmente fácil & $\begin{array}{l}\text { Virtualmente sem tempo de } \\
\text { aprendizagem }\end{array}$ \\
\hline
\end{tabular}

Quadro 2.5 - Comparação entre mouse e dedos como dispositivos de entrada de informações Fonte: (NIELSEN; BUDIU, 2014, p. 25)

O quadro 2.5 mostra uma comparação entre dispositivos de entrada de informações, as células amarelas indicam qual dispositivo é superior para cada uma das dimensões. O tempo de deslocamento é o tempo necessário para mover as mãos de um dispositivo de entrada, como o teclado, para o outro, como o mouse; e o movimento acelerado é a capacidade de ter um relacionamento linear entre a velocidade de movimento do dispositivo e do ponteiro na tela.

A comparação entre os dispositivos de entrada demonstra que cada um tem suas vantagens e desvantagens de acordo com a situação de uso. 


\subsection{3.}

\section{Diferenças na alimentação de informações no desktop/laptop e no smartphone}

Tal como aprender a usar a internet pela primeira vez no desktop/laptop, o ambiente móvel também trouxe seus próprios desafios: novas variáveis foram introduzidas, na experiência móvel deve-se levar em conta a operadora, o tipo de dispositivo, o sistema operacional e o tamanho da tela, a soma desses fatores são o que o Mendoza (2014) denomina de "equação móvel". O autor defende que o modo de usar um dispositivo móvel não é o mesmo que de um desktop/laptop. Um usuário quando utiliza um computador de mesa normalmente encontra-se em uma situação em que pode e pretende dedicar sua atenção àquela interação. Em contraste, ao utilizar um dispositivo móvel, o usuário pode estar na fila de um banco, esperando para ser atendido ou em um consultório médico. O tempo médio por interação é menor e a atenção do usuário está sendo normalmente dividida com fatores externos. Portanto, a sua sessão está sempre na iminência de ser interrompida. Wroblewski (2011) denomina essa atenção dividida com fatores externos de "um polegar e um olho", referindo-se ao modo como se opera um smartphone (com um polegar), a estar-se sempre com um olho na tela e com o outro no que está acontecendo ao redor.

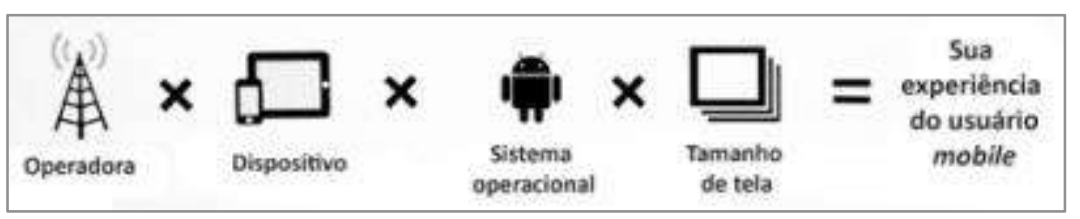

Figura 2.4 - Equação móvel. Fonte: Adaptado de (MENDOZA, 2014, p. 8).

Usuários utilizam um sistema com um objetivo em mente e os designers e desenvolvedores devem entender qual é esse objetivo e assisti-los para que aquele seja atingido (JOHNSON, JEFF, 2010).

Desenvolvedores costumam ser centrados em suas próprias habilidades e conhecimentos e acabam por subestimar as diferenças entre seu modelo mental e o do usuário (CHAMMAS; QUARESMA; MONT’ALVÃO, 2013, p. 166).

Segundo Clark (2010), existem basicamente 4 tipos de comportamento do usuário de dispositivos móveis, cada qual com objetivos diferentes são eles: quem 
está procurando informações urgentes, locais e precisa de uma resposta imediata; quem está explorando e jogando para "matar o tempo"; aquele que está conferindo o status de algo importante e em constante mudança; e aquele que precisa executar uma tarefa urgente como responder a um e-mail de trabalho. Usuários de smartphones tendem a ser orientados à tarefa e preferem interfaces mais simples e intuitivas que os ajudem a cumprir os seus objetivos com facilidade e rapidez (YU; KONG, 2016).

Além das diferenças no comportamento do usuário ao utilizar dispositivos móveis em relação aos fixos, também existem motivos diversos que levam o usuário a optar por uma modalidade ou a outra. O relatório Global Digital Future in Focus, da ComScore (2016) aponta as diferenças de uso entre um smartphone e um desktop. O smartphone é utilizado majoritariamente para acessar mídias sociais. O pico de uso do desktop acontece no período de 10:00 às 17:00, indicando que seu uso se passa mais no horário em que as pessoas estão trabalhando. O relatório também indica que a maioria dos usuários que usa exclusivamente dispositivos móveis (smartphones e tablets) tem entre 25 e 35 anos, enquanto aqueles usuários que usam exclusivamente o desktop a sua maioria tem mais de 55 anos.

\subsection{4.}

Diferenças de performance e desempenho no desktop/laptop e no smartphone

Apesar da ubiquidade dos smartphones nem sempre há sinal de internet de qualidade para acompanhá-los. Isso pode ocorrer em decorrência de uma rede sobrecarregada ou pela mera ausência de sinal. As redes sem fio estão longe de serem onipresentes, quando a velocidade é baixa a carga de cada página é importante, pois há sempre uma chance de queda. A velocidade é um dos motivos que contribuem para o fraco desempenho dos usuários nos smartphones (NIELSEN; BUDIU, 2014). Mesmo com a introdução de velocidades mais rápidas de conexão, com os serviços de $3 \mathrm{G}$ ou $4 \mathrm{G}$, e de dispositivos com processadores de alto desempenho, acessar a próxima tela pode igualar-se ao tempo de resposta que se obtinha com conexões discadas. Projetar sítios móveis (projetados para dispositivos móveis) pensando no desempenho irá beneficiar 
também a eficiência do seu sítio completo (projetados para dispositivos desktops) (WROBLEWSKI, 2011).

A navegação em um browser (navegador) móvel não é como em um desktop. A cada nova aba aberta equivale a uma janela e a navegação entre janelas não é tão fácil, alguns recursos não funcionam tão bem no browser móvel quanto no de um desktop (MENDOZA, 2014). Nielsen e Budiu (2014) sugerem: simplificar a interação, de forma que envolva a carga do menor número possível de páginas, incluir somente as informações úteis para os seus usuários, não utilizar imagens desnecessárias. E, por último, fornecer ao usuário um retorno sobre o andamento do download.

\section{6.}

\section{Observações sobre o Capítulo 2}

A usabilidade de um produto é essencial para oferecer-se uma experiência do usuário positiva. A primeira é um conceito mais consolidado nos estudos da interação humano-computador; a última é um conceito mais recente e, por sua natureza subjetiva torna-se difícil de definir e medir.

Além de preocupar-se com a usabilidade, o designer deve preocupar-se também com o tipo de dispositivo para o qual está projetando e, acima de tudo, com o usuário para o qual está projetando. No caso desta pesquisa serão comparadas as experiências do usuário ao interagir com sítios de e-commerce de vestuário feminino acessados por meio de um desktop e de um smartphone. Neste capítulo foi listado e categorizado um conjunto de princípios usabilidade que posteriormente servirão como base para o teste de usabilidade.

Este capítulo também abordou as principais diferenças ao projetar-se para desktops e smartphones e enfatizou a importância de considerar-se o diálogo entre dispositivo, usuário e ambiente de uso, como prevê a ISO 9241. Os princípios para ambas as modalidades, desktops e smartphones são os mesmos, mas a avaliação do designer de como usá-los deve ser mais rígida para os smartphones (NIELSEN; BUDIU, 2014).

No capítulo seguinte, será traçado um panorama do cenário de e-commerce no Brasil principalmente no que refere-se ao segmento de moda e acessórios, objeto de estudo desta pesquisa. Serão abordadas algumas questões sobre o 
comportamento do consumidor e seus modelos mentais no processo decisório de compras e os problemas mais comuns em sítios de e-commerce de vestuário feminino. 


\section{E-commerce, seus conceitos, aspectos ergonômicos e o consumo on-line}

O capítulo 2 discutiu a respeito de alguns conceitos de usabilidade e experiência do usuário, os dois principais pilares sobre os quais se baseia esta pesquisa. No capítulo a seguir serão discutidos e apresentados conceitos sobre o e-commerce; seus principais tipos, um panorama dos cenários global e brasileiro, além dos aspectos ergonômicos e de usabilidade relacionados ao $e$ commerce.

Embora os termos internet e web ou rede sejam com frequência usados indistintamente, eles são na verdade diferentes. A internet é uma rede mundial de computadores, e a web é um dos serviços mais populares da internet, proporcionando acesso a uma enorme quantidade de páginas (LAUDON; TRAVER, 2016).

O comércio eletrônico, ou e-commerce, refere-se ao uso da internet e intranets para comprar, vender, transportar ou comercializar dados, bens ou serviços (TURBAN et al., 2015). De acordo com Laudon e Traver (2016) ecommerce é o uso da internet, da web e de aplicativos e navegadores móveis em execução em dispositivos móveis para realizar negócios. Mais formalmente: são transações comerciais habilitadas digitalmente entre organizações e indivíduos, incluem todas as transações mediadas pela tecnologia digital. De uma forma geral, isso significa operações realizadas por meio da internet, da web e/ou de dispositivos móveis. Vale ressaltar que transações comerciais envolvem uma troca de valor entre organizações ou indivíduos para a obtenção de produtos e serviços. A troca de valor é importante para a compreensão dos limites do $e$ commerce, sem esta, não há a caracterização de comércio (LAUDON; TRAVER, 2016). 


\section{1.}

\section{E-business e e-commerce}

O termo e-business, foi cunhado pela IBM, em 1996 (GERSTNER, 2002), define-se como:

O processo de usar a tecnologia da web para ajudar as empresas a agilizarem processos, melhorar a produtividade e aumentar a eficiência. Permite que as empresas comuniquem-se facilmente com parceiros, fornecedores e clientes; para conectar sistemas de dados back-end; e realizar transações comerciais de forma segura (SMITH; CHATFIELD; UEMURA, 2001, p. 1).

Para Turban et al. (2015) o termo eletronic business ou e-business (negócio eletrônico) refere-se a uma definição mais ampla de $e$-commerce, não apenas à compra e venda de bens e serviços, como também à realização de todos os tipos de negócios on-line, atendimento a clientes, colaboração com parceiros de negócios, e-learning (aprendizado on-line) e realização de transações eletrônicas dentro de uma organização. Alguns estudiosos como Rayport e Jaworski (2003, apud SCHNEIDER, 2011) argumentam que o e-commerce engloba todo o universo de atividades organizacionais baseadas eletronicamente que dão suporte às negociações de uma empresa, incluindo a infraestrutura do sistema de informação. Por outro lado, há quem defenda que o e-business engloba todo o mundo de atividades internas e externas baseadas eletronicamente, incluindo o $e$ commerce (KALAKOTA; ROBINSON, 2003 apud SCHNEIDER, 2011).

Frequentemente, e-business e e-commerce são tratados como sinônimos, porém são conceitos diferentes. O termo commerce, comércio, em português, está relacionado com a troca de mercadorias e de valores financeiros. O termo business, negócio, em português, por outro lado, denota procedimentos ou atividades comerciais mais gerais, e está relacionado ao negócio como um todo. Em suma, e-commerce é o conjunto de atividades comerciais que acontecem online. O e-business, por sua vez, é uma negociação feita digitalmente, que não envolve necessariamente uma transação comercial. O e-business compreende um complexo sistema de integração, envolvendo o e-commerce (MIRANDA, 2004). $\mathrm{O}$ e-commerce é o ato de vender produtos e serviços na internet, é um elemento do e-business. Preocupa-se com a venda de produtos e serviços entre empresas, de empresas a consumidores (SMITH; CHATFIELD; UEMURA, 2001) e mais recentemente de consumidores para consumidores. Para fins de esclarecimento, o 
usuário é a pessoa que interage com um produto/sistema (ABNT, 2002). Este termo será utilizado em referência a um indivíduo que não esteja inserido em um âmbito de compras. Consumidor é uma pessoa que tem uma necessidade ou um desejo, faz uma compra e depois descarta o produto durante as três fases do processo de compra (SOLOMON, 2011). Este termo será adotado, quando for feito uma referência ao sujeito em um âmbito de consumo.

\section{2.}

\section{Principais conceitos do e-commerce}

Vários outros conceitos são frequentemente usados em conjunto com o $e$ commerce. Os principais são os seguintes:

a) e-Commerce puro e parcial: o e-commerce pode ser puro ou parcial, dependendo da natureza de suas três principais atividades: pedidos e pagamentos, cumprimento dos pedidos e entrega aos clientes. Cada atividade pode ser física ou digital. Se todas as atividades são digitais, é um e-commerce puro, se nenhuma é digital não é um e-commerce. Se existe pelo menos uma etapa digital no processo de venda, considera-se um e-commerce parcial. A título de exemplo: comprar um computador no sítio Dell.com ou um livro na Amazon.com é parcial, porque a mercadoria é entregue fisicamente. Entretanto, comprar um livro eletrônico na Amazon.com ou um software na Buy.com é um e-commerce puro, pois requisitar, processar e entregar ao comprador são ações feitas digitalmente (TURBAN et al., 2015).

\section{b) Organizações de e-commerce}

As organizações que não possuem presença digital são chamadas de físicas (brick-and-mortar, em inglês), enquanto as empresas que estão envolvidas apenas no e-commerce são consideradas organizações virtuais (pureplay). Organizações virtuais e físicas (click-and-mortar ou click-and-brick, em inglês) são as que conduzem algumas atividades do e-commerce. Gradualmente, muitas empresas físicas estão mudando para um modelo parcial.

\section{c) Tipos de e-commerce}

Os diferentes tipos de e-commerce são diferenciados pela natureza da relação de mercado, quem está vendendo a quem. Abaixo descreve-se algumas 
das principais categorias de e-commerce. Alguns termos serão mantidos em inglês ao longo desta dissertação pois tornaram-se conhecidos naquela língua.

\section{- Business-to-Consumer: B2C (Da empresa para o consumidor):}

A categoria de e-commerce mais discutida é a business-to-consumer, ou B2C (do negócio para o consumidor), na qual as empresas on-line objetivam alcançar os consumidores individuais. O comércio B2C inclui a venda de produtos, serviços e conteúdo on-line ao consumidor final (LAUDON; TRAVER, 2016; SCHNEIDER, 2011).

\section{- Business-to-Business: B2B (De empresa para empresa):}

É a categoria do e-commerce entre empresas, B2B, como é chamada. Nesta modalidade as empresas concentram-se em vender a outras empresas (LAUDON; TRAVER, 2016). De acordo com Qin (2009) desempenha um papel central e será a principal categoria de e-commerce.

\section{- Consumer-to-Consumer: C2C (Do consumidor para o consumidor):}

Esta forma de e-commerce, o $\mathrm{C} 2 \mathrm{C}$, é uma maneira dos consumidores venderem produtos e serviços uns aos outros, com a ajuda de um criador de mercado on-line (também chamado de provedor de plataforma), como a OLX ou o Mercado Livre. No C2C, o consumidor prepara o produto para o mercado, coloca-o à venda utilizando algum provedor de serviços de venda on-line (LAUDON; TRAVER, 2016). O consumidor vendedor atua como um negócio e pode ser considerado uma parte do e-commerce B2C (SCHNEIDER, 2011).

\section{- Mobile commerce: m-commerce (E-commerce móvel):}

O e-commerce móvel, ou m-commerce, refere-se ao uso da tecnologia sem fio para conectar dispositivos móveis portáteis à internet. Uma vez conectados, os consumidores móveis podem realizar transações, que incluem: comparações de preços entre lojas, serviços bancários, reservas de viagens, entre outros, sejam eles empresas ou consumidores individuais. (CHAN, SUSY; FANG, 2001; LAUDON; TRAVER, 2016). Essas atividades são geralmente agrupadas sob o termo $\mathrm{m}$ business. (SIAU; LIM; SEN, 2003).

\section{- Social e-commerce (E-commerce social):}


O e-commerce social, o social e-commerce, é realizado por intermédio de redes sociais on-line. Às vezes também refere-se-lhe como Facebook commerce, mas estende-se além do Facebook. O crescimento do e-commerce social está sendo impulsionado por uma série de fatores, incluindo a crescente popularidade do sign-on social (o registro em sítios usando sua identidade do Facebook ou outra identidade de alguma rede social), notificação de rede (o compartilhamento de aprovação ou desaprovação de produtos, serviços e conteúdo por meio do botão de Like do Facebook ou de tweets do Twitter), ferramentas de compras online colaborativas e pesquisa social (recomendações de amigos on-line confiáveis) (LAUDON; TRAVER, 2016).

- Local e-commerce (E-commerce local):

O e-commerce local, como o próprio nome sugere, é uma forma de $e$ commerce que concentra-se em envolver o consumidor com base em sua localização geográfica atual. Comerciantes locais usam uma variedade de técnicas de marketing on-line para conduzir os consumidores para suas lojas. O ecommerce local é a terceira parte da onda móvel, social e local de e-commerce e é alimentada por uma explosão de interesse em serviços locais por demanda como o aplicativo de serviço de motoristas particulares, por exemplo: o Über (LAUDON; TRAVER, 2016).

\section{3.}

\section{Panorama mundial e nacional do e-commerce}

De acordo como o relatório da The Nielsen Company (2017), em 2016 existiam 3.5 bilhões de pessoas utilizando a internet mundialmente. Em 2015, 1.436.500.000 de usuários de internet eram e-shoppers (pessoas que compram online) (ECOMMERCE FOUNDATION, 2016b). Dentre as categorias de bens duráveis, a de artigos de vestuário ocupa o primeiro lugar de vendas, 58\% dos consumidores declararam já terem comprado pelo menos um produto desta categoria, seguido de $55 \%$ de serviços de viagens e $50 \%$ de livros/música/papelaria.

Os avanços em tecnologia, logística e formas de pagamento, juntamente com o acesso crescente à internet móvel e à demanda do consumidor por 
conveniência criaram um cenário mundial de compras on-line que movimenta atualmente U\$1,9 trilhão (KPMG, 2017).

A Figura 3.1 ilustra alguns números do e-commerce no País. Existem atualmente 101.5 milhões de pessoas, $63.7 \%$ da população, com acesso à internet, destas 38.1 milhões, ou 38\%, são e-shoppers (ECOMMERCE FOUNDATION, 2016a). No primeiro semestre de 2017, foi registrado um faturamento de $R \$ 21$ bilhões no e-commerce e 50,3 milhões de pedidos, $24,6 \%$ foram realizados por meio de dispositivos móveis. A categoria de Moda e Acessórios foi a líder em volume de pedidos, representando $14 \%$ do total. O Sudeste é a Região com o maior número de pedidos feitos on-line, responsável 62,8\% (Figura 3.1 e 3.2) (E-BIT, 2017b).

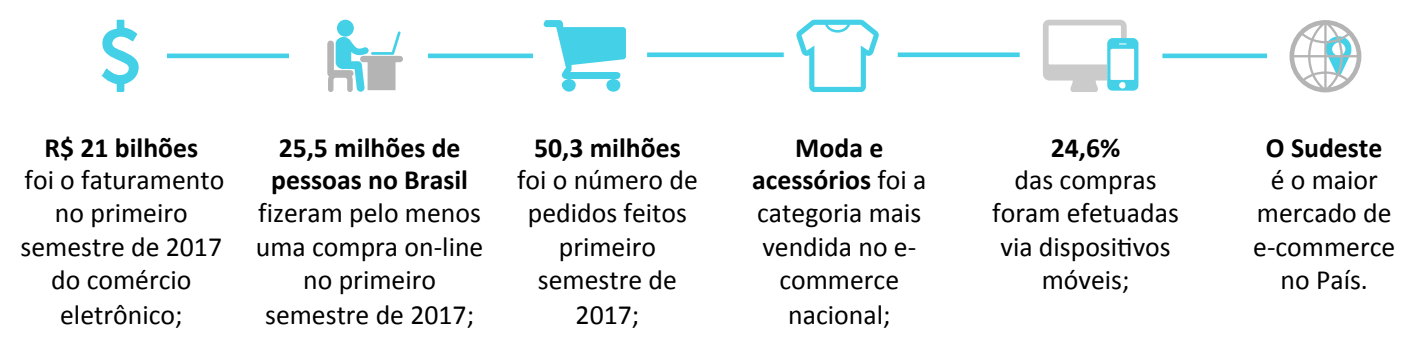

Figura 3.1 - Números do e-commerce. Fonte: adaptado de (SEBRAE-RJ, 2015).

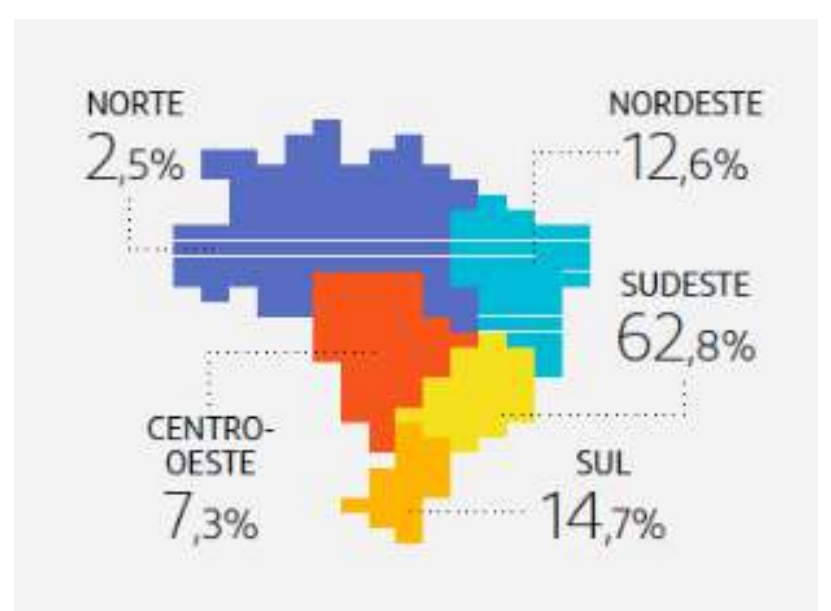

Figura 3.2 - Distribuição da compras feitas por meio da internet pelas Regiões do País no primeiro semestre de 2017. Fonte: E-BIT, 2017, p. 14.

O perfil dos e-shoppers no Brasil é formado por 50,4\% mulheres e 49,6\% homens, uma distribuição bem equilibrada, e tem uma idade média de 43 anos (Figura 3.3). 

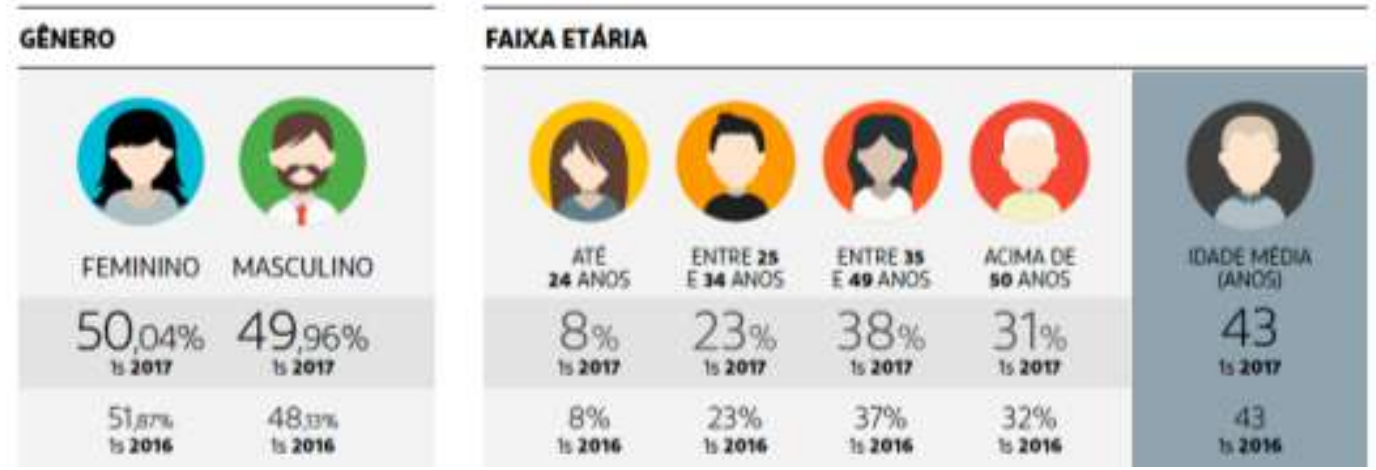

Figura 3.3 - Perfil dos compradores no primeiro semestre de 2017. Fonte: E-BIT, 2017, p. 13.

\section{4 .}

O m-commerce

$\mathrm{O}$ mobile commerce, ou o m-commerce, é o e-commerce com o uso de dispositivos móveis, mais popularmente os telefones móveis. Dois eventos contribuíram para tornar os telefones móveis mais viáveis como dispositivos para navegar na web. Primeiro, as redes de telefonia móvel de alta velocidade tornaram-se dramaticamente mais disponíveis para a população e os fabricantes começaram a oferecer uma grande variedade de telefones que incluem um navegador, uma tela grande o suficiente para torná-lo utilizável, um sistema operacional e a capacidade de executar aplicativos neste sistema operacional.

Há duas vertentes que discutem o potencial e as oportunidades do $m$ commerce (Waters, 2000 apud CHAN; FANG, 2003). Uma delas argumenta que o canal móvel sem fio deve ser visto como uma extensão do atual canal de $e$ commerce ou parte das estratégias multicanal de uma empresa para atingir clientes, funcionários e parceiros. Outra, sugere que o comércio móvel pode criar novos mercados e novos modelos de negócios (CHAN, SUSY S.; FANG, 2003).

As transações comerciais efetuadas por meio de dispositivos móveis tornam-se mais populares a cada ano, porém alinhado ao que Chan e Fang (2003) sugerem, o desktop/laptop ainda é o dispositivo mais utilizado globalmente entre indivíduos de idades diferentes, como aponta um relatório da KPMG (2017) (Figura 3.4). Porém, os dispositivos móveis, em especial o smartphone, têm um papel fundamental na jornada do usuário on-line. Globalmente, mais da metade dos usuários começam o processo de compra utilizando um smartphone (GOOGLE, 2012). No Brasil, em 2016, 55\% dos acessos a sítios de e-commerce 
iniciaram-se em tablets ou smartphones, porém, como sítios adaptados a dispositivos móveis ainda não são uma realidade, apenas $26 \%$ das compras são concretizadas nesses dispositivos (CONVERSION, 2016).

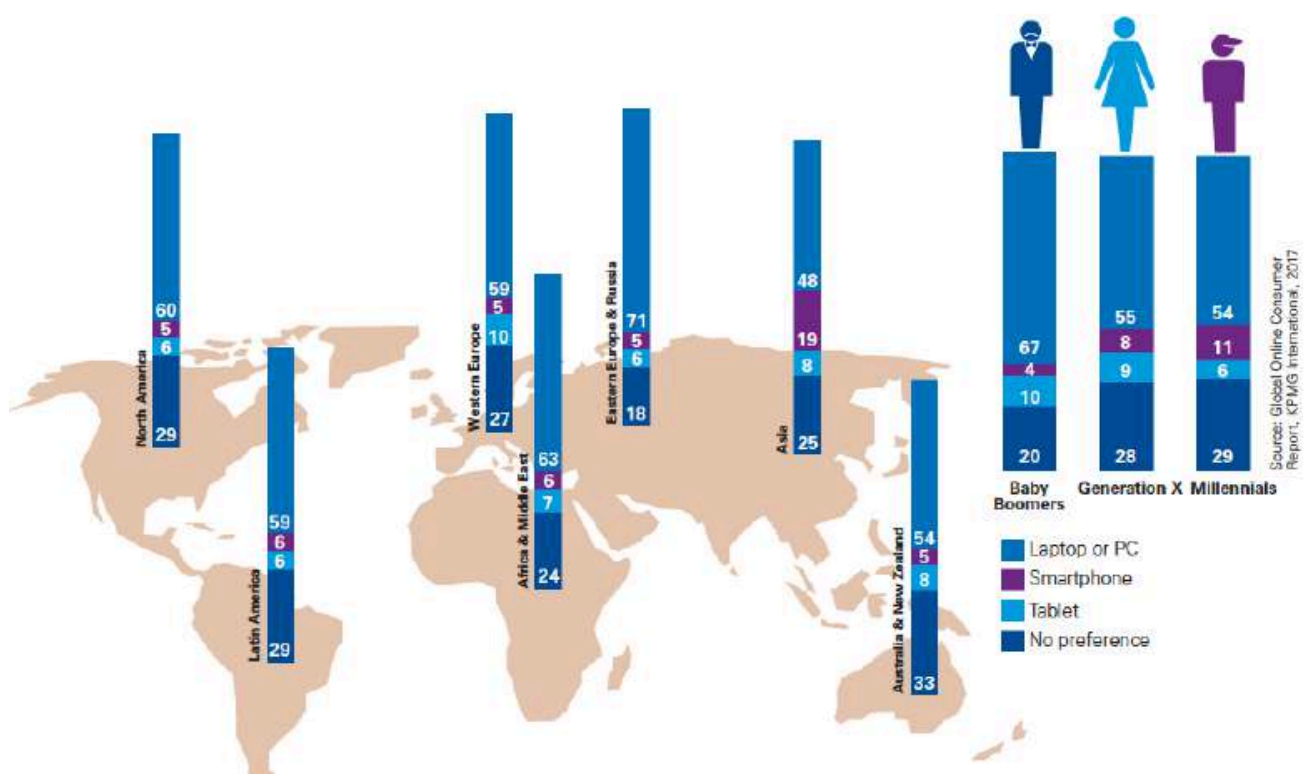

Figura 3.4 - Dispositivo preferido para comprar on-line. Fonte: (KPMG, 2017, p. 11).

\section{5 .}

\section{Ergonomia e usabilidade no e-commerce}

Como apresentado no capítulo 2, a usabilidade mede o quanto um produto pode ser usado com eficácia, eficiência e satisfação em um contexto específico de uso por um determinado usuário, seja um sítio, um aplicativo ou qualquer dispositivo operado por eles. Os princípios de usabilidade desenvolvidos por Nielsen (1993) orientaram o desenvolvimento de aplicativos de e-commerce, são eles:

1. Facilidade de aprendizagem: o quão rápido um usuário novato pode aprender a usar uma interface suficientemente bem para executar tarefas básicas?

2. Eficiência de uso: uma vez que um usuário experiente aprendeu a usar o sistema, quão rápido ele pode realizar tarefas?

3. Facilidade de memorização: Um usuário pode lembrar o suficiente para usar o sistema de forma mais eficaz na próxima vez? 
4. Frequência e gravidade do erro: com que frequência os usuários cometem erros, o quão sérios são esses erros e o quão fácil será para ele recuperar-se de um erro?

5. Satisfação subjetiva: o quanto o usuário gosta de usar o sistema?

A usabilidade ganhou uma crescente atenção no desenvolvimento de sítios. Um grupo de estudiosos da área transformaram esses princípios em um conjunto de diretrizes para serem aplicados no projeto de sítios de e-commerce que resultou em um relatório intitulado e-commerce User Experience. escrito por especialistas do NNGroup em 2000 (CHAN; FANG, 2003 apud Nielsen, Farrell, Snyder e Molich, 2000a, 2000b, 2000c, 2000d). As diretrizes desenvolvidas concentram-se no design das páginas de categoria de produtos, do processo de check-out e registro, das páginas de produtos e na confiança do usuário. As diretrizes estão listadas a seguir:

- Página inicial (homepage) - as páginas da web devem ser limpas e sem excesso de texto e gráficos. A rolagem horizontal deve ser evitada;

- Navegação - o texto nos links ou botões deve ser descritivo e autoexplicativo. Os links para outro sítio, ou página relacionados ao produto devem ser diretos;

- Categorização - os produtos devem ser categorizados de forma significativa com apenas três níveis de profundidade;

- Informação do produto - devem ser fornecidas descrições precisas, consistentes e pormenorizadas de produtos, juntamente com imagens completas. As informações de inventário e as tarifas relacionadas devem ser apresentadas na frente. $\mathrm{O}$ tamanho dos produtos deve ser mostrado de forma mensurável e comparável;

- Carrinho de compras - deveria haver um link direcionando o cliente de volta à página que ele encontrava-se anteriormente para retomar a compra;

- Checkout e registro - a empresa vendedora só deve pedir informações necessárias e significativas, como nome e endereço, e não fazer 
perguntas de marketing. Os clientes devem poder navegar no site sem fazer login;

- Serviço de atendimento ao cliente - os clientes devem ter acesso fácil a um número de telefone de atendimento em cada página do sítio.

O relatório foi atualizado e as diretrizes elaboradas em 2000 provaram-se relevantes até a data da segunda versão publicada em 2011. Apesar de ter registrado melhoras no cumprimento de tarefas por parte dos usuários, um dos autores, Jakob Nielsen, (2011), comenta em um artigo sobre o relatório que a primeira regra do e-commerce permanece: se o usuário não consegue encontrar o seu produto ele não pode comprá-lo. Porém, a nova pesquisa revelou que o problema principal é encontrar informação sobre o produto. É essencial para os usuários terem informações suficientes para sentirem-se confortáveis para fazer um investimento financeiro na compra de um produto ou serviço no sítio de sua escolha. A desvantagem do e-commerce é a de que os usuários não têm um contato físico com o produto, é uma experiência baseada puramente na informação. E para Nielsen (2011) este é mais um motivo para investir-se em conteúdo relevante e de alta qualidade. $\mathrm{O}$ autor também chamou a atenção para o uso de fotos maiores dos produtos.

No seu livro Designing Web Usability, Nielsen (2000) aborda mais questões sobre a usabilidade de sítios on-line. Apesar de ter sido escrito em 2000 a maioria das diretrizes discutidas no livro, assim como no relatório escrito à mesma época, ainda são usadas por muitos especialistas. No quadro 3.1, abaixo, lista-se os itens que são pertinentes para o entendimento desta pesquisa.

\begin{tabular}{|l|l|}
\hline $\begin{array}{l}\text { Design de } \\
\text { página }\end{array}$ & $\begin{array}{l}\text { - O conteúdo de interesse do usuário deve dominar as suas páginas } \\
\text { na web; } \\
\text { - Permitir aos browsers otimizar as telas para as circunstâncias de } \\
\text { cada usuário; } \\
\text { - Deve-se criar uma interface tendo em mente todas as resoluções } \\
\text { de tela e que se adaptem a qualquer tamanho de tela. }\end{array}$ \\
\hline $\begin{array}{l}\text { Tempos de } \\
\text { resposta }\end{array}$ & $\begin{array}{l}\text { Um tempo de resposta rápido é um dos critérios mais } \\
\text { importantes para o design de uma página na web. }\end{array}$ \\
\hline Links & $\begin{array}{l}\text { - Use descrições de links curtas; } \\
\text { - Não usar 'clique' e 'aqui', e sim sublinhe e transforme em link } \\
\text { as palavras com as informações adicionais; } \\
\text { - Inclua títulos de link para explicar para onde o usuário está indo; } \\
\text { - Como colorir os links: não use cores de links atípicas, podem }\end{array}$ \\
\hline
\end{tabular}




\begin{tabular}{|c|c|}
\hline & $\begin{array}{l}\text { Confundir o usuário e aumentar o tempo de resposta dele; } \\
\text { - Marque como lido links que se repetem na página e que o } \\
\text { usuário já tenha visitado, para ele não visitar novamente; } \\
\text { - Explique ao usuário o que ele ganhará ao clicar no link; } \\
\text { - Situe claramente o usuário na página de chegada (landing page); } \\
\text { - Não abra novas janelas no browser, isso desativa o botão voltar. }\end{array}$ \\
\hline Credibilidade & - Um design limpo e bonito passa credibilidade ao usuário. \\
\hline $\begin{array}{l}\text { Escrevendo } \\
\text { para a web }\end{array}$ & $\begin{array}{l}\text { - Seja sucinto, facilite a leitura use parágrafos curtos, tópicos, } \\
\text { listas, subtítulos; } \\
\text { - Mantenha os textos breves; } \\
\text { - Coloque os links mais importantes acima da dobra } \\
\text { - Comece o texto pela conclusão. }\end{array}$ \\
\hline Legibilidade & $\begin{array}{l}\text { - Use cores com alto contraste entre o texto e o fundo; } \\
\text { - Use fundos lisos ou padrões extremamente sutis; } \\
\text { - Use fontes de tamanho suficiente para que as pessoas possam ler } \\
\text { o texto; } \\
\text { - Justifique o texto à esquerda. }\end{array}$ \\
\hline $\begin{array}{l}\text { Imagens e } \\
\text { fotografias }\end{array}$ & $\begin{array}{l}\text { - Somente usar elementos gráficos relevantes; } \\
\text { - O usuários querem ver fotos dos produtos que estão comprando. }\end{array}$ \\
\hline Vídeo & - São bons para mostrar produtos que se movem. \\
\hline A homepage & $\begin{array}{l}\text { Sua homepage deve oferecer estas três características: } \\
\text { - Navegação - diretório com as principais áreas de conteúdo; } \\
\text { - Um resumo das notícias ou promoções mais importantes; } \\
\text { - Um recurso de busca. }\end{array}$ \\
\hline $\begin{array}{l}\text { A homepage } \\
\text { vs. as } \\
\text { páginas } \\
\text { internas }\end{array}$ & $\begin{array}{l}\text { - O objetivo da homepage deve ser promover uma mensagem de } \\
\text { boas vindas ou uma visão geral do sítio e as interiores devem ser } \\
\text { mais específicas; } \\
\text { - Coloque a logo marca e o nome do sítio no canto superior } \\
\text { esquerdo de todas as páginas - pode ser um link para voltar para } \\
\text { a home de qualquer página e para o usuário saber em que sítio } \\
\text { ele está se chegar à página por meio de um mecanismo de busca. }\end{array}$ \\
\hline Navegação & $\begin{array}{l}\text { - A navegação deve responder } 3 \text { perguntas: } \\
\text { - Onde estou? } \\
\text { - Onde estive? } \\
\text { - Aonde eu posso ir? } \\
\text { 1. É de suma importância identificar o sítio em todas as páginas; } \\
\text { 2. A navegação deve ser visualizada do ponto atual do usuário; } \\
\text { 3. É importante a estrutura ser centrada no usuário e não na forma } \\
\text { como a empresa é organizada; } \\
\text { 4. Incluir um esquema de suporte à navegação indicando onde o } \\
\text { usuário está, no topo da página usualmente chamado de } \\
\text { breadcrumbs } 5\end{array}$ \\
\hline
\end{tabular}

\footnotetext{
${ }^{4}$ Parte visível de uma página de um sítio on-line na janela de um browser ao acessá-la.

${ }^{5}$ Breadcrumbs: migalhas em português, expressão utilizada para nomear um recurso utilizado para localizar o usuário em um sítio on-line, normalmente localizado na parte superior da página, por exemplo: home $>$ feminino $>$ blusas (NIELSEN, 2000).
} 


\begin{tabular}{|c|c|}
\hline $\begin{array}{l}\text { O usuário } \\
\text { controla a } \\
\text { navegação }\end{array}$ & $\begin{array}{l}\text { - Criar projetos que visem à liberdade de movimento e à } \\
\text { navegação flexível; } \\
\text { - Projete de acordo com as convenções já existentes na web; } \\
\text { - Filtragem - mostrar somente o que é útil. }\end{array}$ \\
\hline Subsítios & $\begin{array}{l}\text { - Os usuários precisam entender os vários espaços informacionais } \\
\text { que navegam; } \\
\text { - Utilizar breadcrumbs para situar o usuário; } \\
\text { - Cada subsítio deve conter um link para voltar à homepage do } \\
\text { subsítio, bem como para a homepage principal. }\end{array}$ \\
\hline Busca & $\begin{array}{l}\text { - Cite explicitamente em qual parte do sítio a busca está sendo } \\
\text { realizada; } \\
\text { - Ofereça uma busca avançada se for diferente da busca simples; } \\
\text { - Inclua verificações ortográficas e expansão de sinônimos. } \\
\text { - Na página de resultados de busca: } \\
\text { Apresente os resultados mais relevantes primeiro; } \\
\text { Eliminar duplicidades; } \\
\text { Agrupar por relevância. } \\
\text { - Encoraje buscas mais precisas. }\end{array}$ \\
\hline
\end{tabular}

Quadro 3.1: Diretrizes para sítios on-line. Fonte: (NIELSEN, 2000).

Em suma, Nielsen (2000) aponta que a simplicidade deve ser a meta ao projetar sítios. Os usuários raramente acessam um sítio para desfrutar do design; mas sim para desfrutarem do conteúdo. Assim como Nielsen, o autor do livro Content is King, Mill (2005) enfatiza a importância do conteúdo ser relevante para os usuários, as informações mais importantes devem vir no começo, os textos devem ser concisos e fáceis de ler. Os usuários raramente leem palavra por palavra quando estão on-line.

Deve-se garantir que todas as páginas funcionem em navegadores e versões diferentes. Além disso, certificar-se que o design da página funciona em monitores pequenos e tenha tempos de resposta aceitáveis. A navegação deve ser simples, ter poucas distrações e obedecer à uma arquitetura da informação clara baseada nas necessidades do usuário e não da empresa.

A homepage de um sítio deve informar ao usuário sobre quais tipos de tarefas ele poderá realizar e deve conter o nome da empresa e seu logotipo.

Metáforas são excessivamente usada no webdesign, estas são uma analogia empregada no design para comunicar e explicar conceitos desconhecidos usando conhecimento familiar convencional (HARTSON; PYLA, 2012). As metáforas controlam a complexidade ao permitir que os usuários adaptem o que já sabem ao usarem novos recursos do sistema e facilitam o aprendizado. As metáforas do 
carrinho, ou da sacola de compras assim como a da lata de lixo, fazem com que os usuários entendam imediatamente quais são as suas funcionalidades básicas (NORMAN, DONALD A., 2004).

\section{6.}

\section{Usabilidade para o $\mathrm{m}$-commerce}

No capítulo 2, abordou-se as questões primordiais sobre as diferenças de experiência de uso entre os laptops/desktops e dispositivos móveis. Tratando-se especificamente o e-commerce em ambas as mídias, Ajibola e Goosen, (2014) resumem bem a questão: o erro mais comum dos projetistas desta categoria de sítios é achar que o m-commerce iguala-se ao e-commerce. Idealmente deve-se projetar sítios diferentes para serem acessados de laptops/desktops e dispositivos móveis. No entanto, por questões financeiras, nem sempre é possível desenvolver sítios ou até mesmo aplicativos dedicados exclusivamente ao acesso em dispositivos móveis. Basicamente, cada tamanho de tela demanda um projeto diferente. Nielsen e Budiu (2014) recomendam: eliminar funcionalidades que não sejam fundamentais, reduzir a quantidade de palavras e transferir informações secundárias para páginas secundárias e aumentar os elementos da interface para amenizar o problema do "dedo gordo" (Capítulo 2). O reduzido espaço da tela dos dispositivos móveis e sua natureza portátil demandam do designer uma cautela muito maior.

A pesquisa de usabilidade em dispositivos móveis tem geralmente como objetivo resolver as questões impostas por limitações de velocidade de navegação e pelo tamanho das telas dos dispositivos (CHAN, SUSY S.; FANG, 2003). Com base na revisão da literatura realizada pelos autores eles identificaram que diversos estudos também abordam questões relacionadas com a entrada de dados utilizando os teclados dos dispositivos móveis.

Chan et al. (2002) realizaram uma análise de diversos sítios móveis e concluíram que alguns problemas de usabilidade são recorrentes tais como: downloads demasiadamente longos, conexão interrompida, sobrecarga de informação e rolagem de tela excessiva. Eles sugerem 8 diretrizes:

1. Evitar a rolagem de página, 
2. Usar uma hierarquia plana,

3. Criar um sistema de navegação consistente com um navegador da web regular;

4. Projetar um botão "voltar";

5. Fornecer o histórico de navegação,

6. Fornecer uma indicação da intensidade do sinal,

7. Reduzir a carga de memória do usuário e

8. Limitar o escopo da busca para melhorar sua eficiência.

(CHAN, SUSY S.; FANG, 2003)

A adoção de dispositivos móveis, especialmente os smartphones, é cada vez maior, 65\% dos usuários iniciam o processo de compras on-line em um smartphone (GOOGLE, 2012). Por este motivo, a Google desde 2016, vem testando algoritmos para suportar a grande quantidade de pessoas que utilizam smartphones para realizar buscas na web (PHAN, 2016). A usabilidade e a experiência do usuário móvel torna-se de forma exponencial cada vez mais relevante.

\section{7.}

\section{Modelos mentais}

Como forma de conhecer melhor os usuários de sistemas digitais é importante entender os seus modelos mentais. Carroll e Olson (1987) os definem como uma representação mental que um usuário tem de um sistema e das associações que ele faz entre as entradas e saídas (inputs e outputs) de informação. É uma estrutura rica e elaborada que reflete a compreensão do usuário sobre o conteúdo de um sistema, como ele funciona e por que funciona daquela forma. É este processo que permite ao usuário não só construir ações para novas tarefas como também explicar por que uma determinada ação produz um determinado resultado.

De acordo com a definição de Norman (2013) modelos mentais são um modelo conceitual presente na mente das pessoas que representa seu entendimento de como as coisas funcionam. Ao projetarem, os designers utilizam as informações acerca de um sistema já existente (artigos, sítios, publicidade, manual de instruções, 
etc.), ou o que o autor denomina de "imagem do sistema". Quando esta imagem é incoerente ou inapropriada resultam em sistemas de difícil compreensão e uso.

Cooper et al. (2014) explicam que existem três formas de visualização de um sistema. A primeira refere-se a representação de como um sistema realmente funciona chamado de "modelo de implementação". A maneira como os usuários percebem o que eles precisam fazer para realizar uma tarefa e como o sistema os ajuda nisto é o seu "modelo mental". Baseiam-se nas suas noções de como eles executam suas tarefas diárias e como eles imaginam que os computadores possam funcionar. A forma como os designers escolhem representar o funcionamento do sistema por meio de uma interface para o usuário interagir é chamado de "modelo representado". Ao contrário dos outros dois modelos, trata-se de um aspecto do sistema sobre o qual os designers exercem grande controle. Um dos objetivos mais importantes do designer deve ser fazer com que o modelo representado aproxime-se o quanto possível do modelo mental de um usuário. Portanto, é fundamental que os designers entendam minuciosamente como os usuários executam suas tarefas, ele deve compreender o modelo mental do usuário e como este interage com o sistema.

Sítios de e-commerce não são diferentes, ao serem projetados devem ser guiados pela maneira como os usuários entendem aquele sistema e de acordo com os seus modelos mentais. Os usuários buscam relações de causa e efeito para explicar o que observam e por quê. Desta forma, orientam suas ações ao realizarem uma tarefa (HARTSON; PYLA, 2012).

Conforme mencionado acima, a imagem que o usuário faz da interface, influencia o seu comportamento assim como sua experiência com sistemas com os quais já interagiu, além de fatores culturais. A qualidade da decisão tomada depende da qualidade de seu modelo estrutural. A título de exemplo, um usuário novato, desconhecendo certas funções de um sistema, poderá tomar uma decisão que demande realizar novamente, ou parcialmente, uma tarefa ao deparar-se com um erro ou ao cometê-lo (CYBIS; HOLTZ; FAUST, 2010).

Uma interface digital pode considerar quatro modelos mentais genéricos:

a) O modo pelo qual os usuários percebem a interface;

b) O modo pelo qual os projetistas percebem a interface e sua relação com o usuário; 
c) O que a interface efetivamente mostra ao usuário, de modo que possa usá-la intuitivamente; e

d) O modelo conceitual (ou psicológico) que o usuário elabora a partir do que vê (CARROLL; OLSON, 1987; JORDAN, 2001; NIELSEN, 1993, 2009).

Para que os consumidores tomem decisões ao navegarem na web, eles precisam ser capazes de recuperarem, compreenderem, manipularem e usarem facilmente informações relevantes para o processo de tomada de decisão (STIBEL, 2005). Isto posto, os modelos mentais devem ser constantemente reavaliados para garantir que sejam sempre coerentes. Para fornecer uma interface mais intuitiva, é preciso precaver-se para não explorar modelos mentais incorretos. Apresentar ao usuário uma interface que não seja intuitiva poderá leválo a tomar decisões incorretas e a cometer erros de navegação (STIBEL, 2005).

\section{8.}

\section{Comportamento do consumidor: on-line e off-line}

$\mathrm{Na}$ fase da pesquisa descritiva desta dissertação (discutida no capítulo 6 e 7), as voluntárias participantes do teste de usabilidade foram solicitadas a cumprirem algumas tarefas em um sítio de e-commerce, o https://dafiti.com.br/ (referido nesta dissertação apenas como dafiti.com.br). A fim de compreender alguns aspectos da jornada do usuário ao adquirir um produto é importante abordar-se as etapas básicas nas quais consiste o processo decisório de compra.

Os processos de tomada de decisão do consumidor on-line e off-line assemelham-se. O modelo tradicional (Figura 3.5) normalmente começa com o reconhecimento de uma necessidade, seguido da busca de informações acerca de um produto ou serviço, avaliação de alternativas, a decisão de compra ou não daquele produto ou serviço e por fim, o comportamento pós-compra (KATAWETAWARAKS; WANG, 2011; KOTLER, 2000; SOLOMON, 2011). 


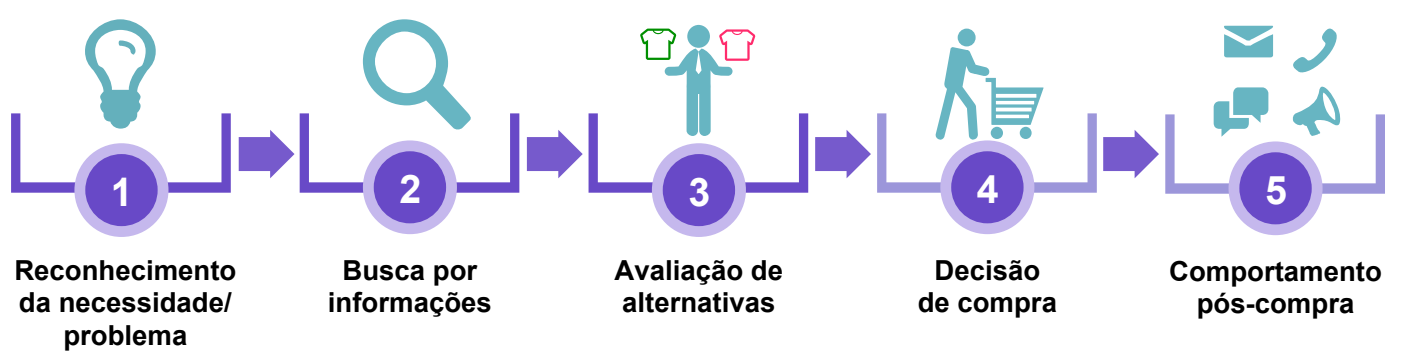

Figura 3.5 - Fases do processo decisório de compra. Fonte: elaborado pela autora, baseado em (KATAWETAWARAKS; WANG, 2011; KOTLER, 2000; SOLOMON, 2011).

Kotler, Keller (2016) e Solomon (2011) explicam as diferentes etapas do processo decisório de compra:

1. O processo de compra começa quando o comprador reconhece um problema ou necessidade desencadeada por estímulos internos ou externos. Estímulos internos podem ser uma tradução das necessidades humanas habituais como fome ou sede. Uma necessidade também pode ser despertada por um fator externo por meio de um estímulo visual vindo de um anúncio em uma mídia social que desencadeia pensamentos sobre a possibilidade de fazer uma compra.

2. A busca por informações é o processo pelo qual os consumidores procuram por dados apropriados para tomar uma decisão. Classifica-se dois níveis de engajamento na busca. O estado de pesquisa mais suave é chamado de atenção aumentada. Neste nível, um sujeito torna-se mais receptivo às informações sobre um produto. No segundo nível, o sujeito realiza uma pesquisa de informações ativa: procura materiais escritos, como artigos e manuais, pede informações para amigos, acessa sítios na web e visita lojas para saber mais sobre o produto. As principais fontes de informação procuradas por consumidores são divididas em quatro grupos:

1) Pessoal: família, amigos, vizinhos, conhecidos;

2) Comercial: publicidade, sites, e-mails, vendedores, revendedores, embalagens, displays;

3) Público: meios de comunicação social, redes sociais, organizações de avaliação do consumidor; e

3) Experiencial: manipulação, exame, uso do produto.

A quantidade de informação e influência destas fontes varia com a categoria do produto e as características do comprador. Mesmo no ambiente on-line, onde não existe contato tátil com o produto antes da compra, o consumidor pode dirigir-se à 
loja física antes de realizar uma compra digitalmente e isto ser um fator determinante no seu processo decisório. Outra característica dos sítios de ecommerce é a forma em que os produtos são apresentados para o consumidor. Podem estar destacados os itens em promoção, ou baseados em um histórico de compras e caso o consumidor não faça uma busca extensiva possivelmente não verá todos os produtos compatíveis com a sua necessidade.

3. Avaliação das alternativas - uma vez reunidas e avaliadas as opções de uma categoria de produto ou serviço, eventualmente tem de se escolher uma. As regras de decisão que orientam as escolhas variam de estratégias muito simples e rápidas a processos complicados que exigem muita atenção e processamento cognitivo. Nenhum processo único é usado por todos os consumidores, existem vários, o consumidor está tentando satisfazer uma necessidade. Em segundo lugar, o consumidor está procurando por certos benefícios no produto. Em terceiro lugar, o consumidor vê cada produto como um conjunto de atributos com diferentes habilidades para oferecer estes benefícios. Os atributos de interesse para os compradores variam de acordo com o produto, por exemplo:

1) Hotéis - localização, limpeza, atmosfera, preço;

2) Lavagem bucal - cor, eficácia, capacidade de matar os germes, sabor, preço;

3) Pneus - segurança, vida do piso, qualidade do passeio, preço.

E aplicando este racional para compras de vestuário, pode considerar-se: a ocasião de uso, conforto, tipo de tecido, preço.

Os consumidores prestarão mais atenção aos atributos que oferecem os benefícios procurados. No teste de usabilidade aplicado na fase da pesquisa descritiva desta dissertação, os usuários foram induzidos a procurar atributos listados nas tarefas a serem cumpridas.

\section{Crenças e atitudes}

Por meio da experiência e do aprendizado, as pessoas adquirem crenças e atitudes. Estas, por sua vez, influenciam o comportamento de compra. A crença é um pensamento descritivo que uma pessoa detém sobre alguma coisa. Tão importantes como as atitudes, avaliações duradouras favoráveis ou desfavoráveis de uma pessoa, sentimentos emocionais e tendências de 
ação em relação a algum objeto ou ideia. As pessoas têm atitudes em quase tudo: religião, política, roupas, música ou comida. As atitudes nos colocam em um estado de espírito: gostar ou não de um objeto, movendo-se para ou afastando-o. Eles nos levam a comportar-se de maneira bastante consistente em direção a objetos semelhantes. Porque as atitudes economizam energia e pensamento, elas podem ser muito difíceis de mudar.

Modelo de Expectativa-Valor

O consumidor chega a atitudes em relação a várias marcas por meio de um procedimento de avaliação de atributos, desenvolvendo um conjunto de crenças sobre a relação de cada marca/produto com cada atributo. O modelo de expectativa-valor da formação de atitude postula que os consumidores avaliem produtos e serviços combinando suas crenças de marca - os aspectos positivos e negativos - de acordo com a importância. Uma produto pode ter as melhor relação de atributos para suprir cada necessidade do consumidor mas a forma como ele enxerga aquela marca pode ser determinante principalmente quando uma marca desconhecida compete com uma conhecida. Ao comprar roupas, um consumidor pode escolher uma marca conhecida por já conhecer seus produtos e saber o que lhe serve, mesmo que seja mais cara.

\section{Decisão de compra}

$\mathrm{Na}$ fase de avaliação, o consumidor escolhe entre diversas marcas as de sua preferência e pode formar a intenção de comprar sua marca favorita. Ao executar uma intenção de compra, o consumidor pode fazer até cinco decisões complementares: marca (marca A), revendedor (revendedor 2), quantidade (um, dois ou três), tempo (fim de semana) e método de pagamento (cartão de crédito).

\section{Comportamento pós-compra}

Após a compra o consumidor pode sentir-se satisfeito ou insatisfeito com a sua aquisição. No ambiente on-line ele só terá contato com o produto quando este for-lhe entregue. A satisfação é uma função da proximidade entre as expectativas e o desempenho percebido pelo produto. Se o desempenho não atende às expectativas, o consumidor está desapontado; 
Se atende às expectativas, o consumidor está satisfeito; se exceder as expectativas, o consumidor está encantado. Esses sentimentos fazem a diferença na experiência total do usuário. Quanto maior a lacuna entre as expectativas e o desempenho, maior a insatisfação.

O comportamento do consumidor é influenciado por três fatores: culturais (cultura, subcultura e classe social), sociais (grupos de referência, família e papéis sociais e status) e pessoais (idade, estágio no ciclo de vida, ocupação, circunstâncias econômicas, estilo de vida, personalidade e auto-concepção). A pesquisa sobre esses fatores pode fornecer pistas para alcançar e atender os consumidores de forma mais eficaz.

O acesso a fontes on-line está mudando a maneira como os usuários decidem o que comprar. A web mudou a forma de buscar informações. Sítios de pesquisa comparativos como o Buscapé.com ou o Zoom.com ajudam a filtrar e orientar o processo de busca. Os consumidores não passarão necessariamente pelo processo de compra de forma ordenada, pularão etapas repetirão outras e alternarão entre canais on-line e off-line, como ilustra a Figura 3.6. Uma estrutura que compara a decisão do consumidor on-line com a tomada de decisão off-line (Figura 3.7) foi desenvolvida por Laudon e Traver, (2016). Os autores sugerem que o modelo geral usado para retratar o comportamento do consumidor ao tomar decisões de compra requer algumas modificações para levar em consideração novos fatores relativos ao âmbito digital.
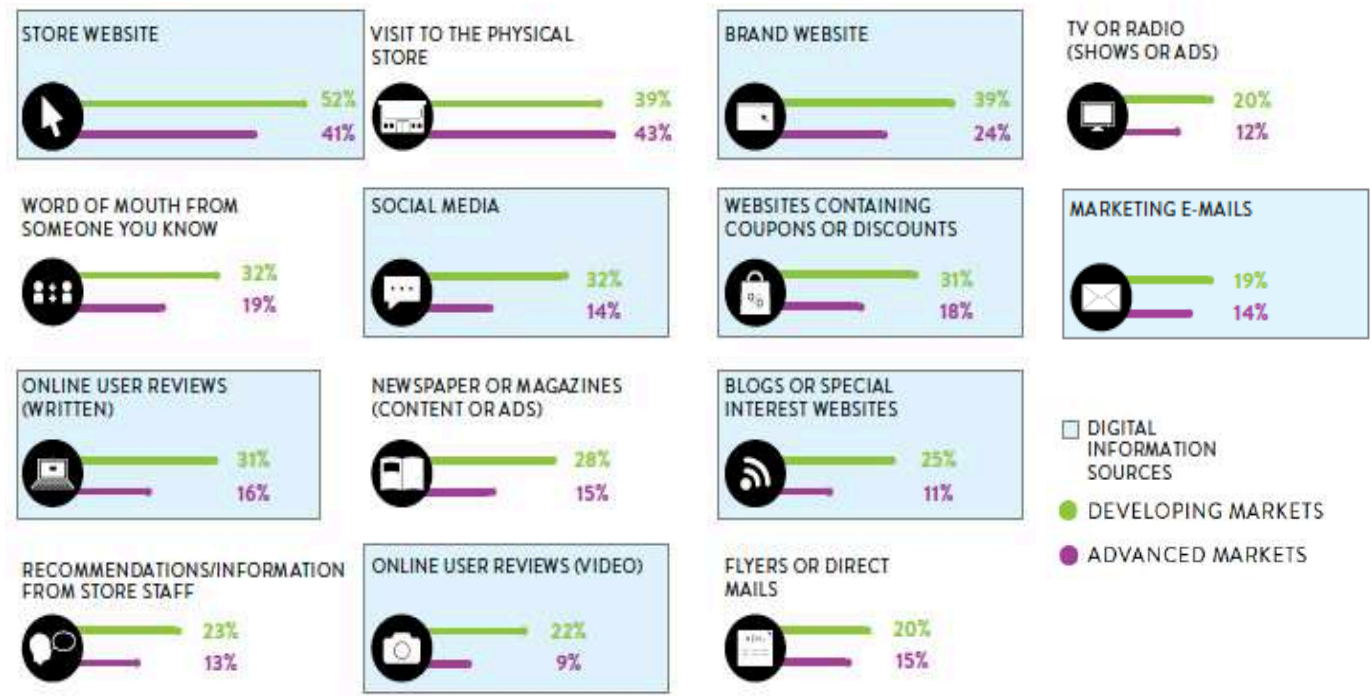

INFORMATION SOURCES

- DEVELOPING MARKETS

FLYERS OR DIRECT

- ADVANCED MARKETS RECOMMENDATION SII MAILS

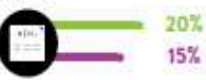

Figura 3.6 - Fontes de informação para tomada de decisão de compra. Fonte: (THE NIELSEN COMPANY, 2017, p. 27). 
$\mathrm{Na}$ fase de avaliação de alternativas, a maneira como a pessoa mentalmente agrupa produtos influencia as alternativas que ela considerará assim como a forma na qual um sítio categoriza e apresenta seus produtos pode ser fundamental nesta etapa.

\begin{tabular}{|c|c|c|c|c|}
\hline $\begin{array}{l}\text { Reconhecimento } \\
\text { da necessidade }\end{array}$ & Busca & $\begin{array}{l}\text { Avaliação de } \\
\text { alternativas }\end{array}$ & Compra & $\begin{array}{c}\text { Comportamento } \\
\text { pós compra - } \\
\text { Fidelidade }\end{array}$ \\
\hline \multicolumn{5}{|c|}{ Comunicação de marketing on-line } \\
\hline $\begin{array}{l}\text { Anúncios } \\
\text { direcionados • E- } \\
\text { mail marketing } \\
\text { Mídias sociais }\end{array}$ & $\begin{array}{l}\text { Buscadores } \bullet \\
\text { Catálogos on- } \\
\text { line } \bullet \text { E-mail } \\
\text { marketing } \bullet \\
\text { Redes sociais }\end{array}$ & $\begin{array}{c}\text { Buscadores } \bullet \\
\text { Catálogos on- } \\
\text { line } \bullet \text { Visitas a } \\
\text { sítios } \bullet \\
\text { Avaliações de } \\
\text { usuários } \bullet \\
\text { Redes sociais }\end{array}$ & $\begin{array}{c}\text { Promoções } \\
\text { on-line • } \\
\text { Descontos • E- } \\
\text { mails } \\
\text { direcionados • } \\
\text { Promoções } \\
\text { instantâneas }\end{array}$ & $\begin{array}{c}\text { Comunidades } \\
\text { on-line } \bullet \\
\text { Newsletters } \\
\text { Atualizações on- } \\
\text { line } \bullet \text { Redes } \\
\text { sociais }\end{array}$ \\
\hline \multicolumn{5}{|c|}{ Comunicação de marketing off-line } \\
\hline $\begin{array}{l}\text { Mídia de massa } \bullet \\
\text { Rádio } \bullet \text { Mídia } \\
\text { impressa } \bullet \text { Redes } \\
\text { sociais }\end{array}$ & $\begin{array}{c}\text { Catálogos • } \\
\text { Anúncios } \\
\text { impressos • } \\
\text { Vendedores • } \\
\text { Visitas às lojas • } \\
\text { Redes sociais }\end{array}$ & $\begin{array}{c}\text { Formadores de } \\
\text { opinião } \bullet \text { Mídia } \\
\text { de massa } \bullet \\
\text { Avaliadores de } \\
\text { produtos } \bullet \\
\text { Visita às lojas } \\
\text { Redes sociais }\end{array}$ & $\begin{array}{c}\text { Promoções • } \\
\text { Descontos • } \\
\text { Correspondência } \\
\text { direcionada • } \\
\text { Mídia de massa } \\
\text { - Mídia impressa }\end{array}$ & $\begin{array}{c}\text { Garantias • } \\
\text { Reparos • } \\
\text { Serviço ao } \\
\text { usuário • Redes } \\
\text { sociais }\end{array}$ \\
\hline
\end{tabular}

Figura 3.7 - O processo decisório do consumidor e os modos de comunicação associados. Fonte: (LAUDON; TRAVER, 2016, p. 382).

\section{9.}

\section{Risco percebido}

As preferências e até as intenções não podem prever de forma completamente confiável o comportamento de compra do consumidor. Este pode modificar, adiar ou evitar uma decisão de compra que por conseguinte é fortemente influenciada por um ou mais tipos de risco percebido, listados abaixo:

- Risco funcional - o produto não é compatível com as expectativas;

- Risco físico - o produto representa uma ameaça para o bem-estar físico ou a saúde do usuário ou de outros;

- Risco financeiro - o produto não vale o preço pago; 
- Risco social - o produto resulta em constrangimento na frente dos outros;

- Risco psicológico - o produto afeta o bem-estar mental do usuário; e

- Risco de tempo - o fracasso do produto resulta em um custo de oportunidade para encontrar outro produto satisfatório.

O grau de risco percebido varia com a quantidade de dinheiro a ser investido, a incerteza acerca dos atributos do produto e o nível de autoconfiança. Os usuários desenvolvem mecanismos para reduzir a incerteza e as consequências negativas do risco, tais como: adiar decisões, reunir informações de amigos e desenvolver preferências por marcas que sejam acessíveis dentro do território nacional e ofereçam garantias. Deve-se entender quais são os fatores que provocam uma percepção de risco nos usuários e a partir desta compreensão fornecer informações e dar suporte para reduzi-la (KOTLER; KELLER, 2016).

Via de regra, as decisões de compra que envolvem uma busca extensiva também envolvem um risco percebido ou a crença de que pode haver consequências negativas se você usar ou não usar um produto ou serviço. Isso pode ocorrer quando o produto é caro ou complexo e difícil de entender como ilustrado na Figura 3.8 (SOLOMON, 2011).

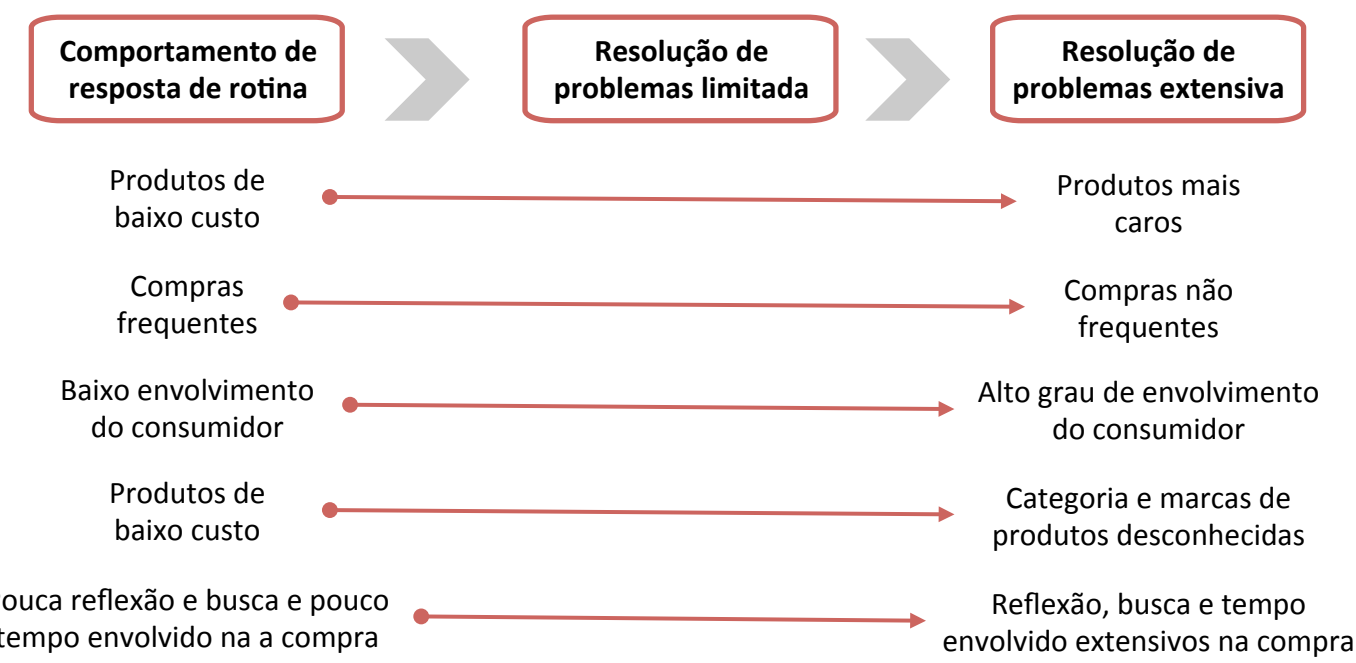

Figura 3.8 - Um contínuo do comportamento decisório de compra. Fonte: (SOLOMON, 2011, p. 298).

Quando os consumidores têm a intenção de comprar algo, analisarão a marca e as características do produto ou serviço. Alguns produtos podem ser comprados e enviados facilmente on-line, como, softwares ou livros. Por outro 
lado, alguns produtos apresentam mais dificuldades no processo de decisão de compra por meio do canal on-line. As características do sítio, a competência da empresa, os estímulos de comunicação de marketing e as habilidades do consumidor também são importantes (LAUDON; TRAVER, 2016).

Os varejistas on-line podem usar a tecnologia para melhorar seus sites, a fim de influenciar as percepções dos consumidores. Se o sítio for muito lento, afetando a navegação, ou não é seguro o suficiente, afetará negativamente a vontade do consumidor de comprar produtos ou serviços (NIELSEN, 2000). A experiência do consumidor com compras on-line, suas habilidades, o conhecimento que ele possui sobre o produto (LAUDON; TRAVER, 2016; NIELSEN, 2000) também influenciam os comportamentos de compras on-line.

Usuários experientes e os novatos adotam procedimentos diferentes durante o processo de tomada de decisão. Novatos sabem pouco sobre um determinado produto e podem ter motivação extra para descobrir mais a respeito. Por outro lado, os experientes são mais familiarizados com determinado produto e, portanto, pressupõe-se que sejam mais aptos a entender o significado das informações sobre o produto que têm a intenção de comprar (SOLOMON, 2011).

Katawetawaraks e Wang (2011) listam os principais motivos que estimulam e impedem o consumidor de efetuar compras on-line:

1. Fatores que motivam:
a) Conveniência;
b) Informação;
c) Produtos e serviços disponíveis; e
d) Eficiência de custo e tempo.

2. Fatores que impedem:

1. Segurança;

2. Intangibilidade do produto on-line;

3. Falta de contato social; e

4. Insatisfação com as compras on-line.

Um relatório elaborado pela KPMG (2017), The truth about the online consumer, mostra que os principais motivos que levam o consumidor a comprar 
em lojas físicas (Figura 3.9) estão ligados à necessidade de tocar e/ou experimentar o produto.

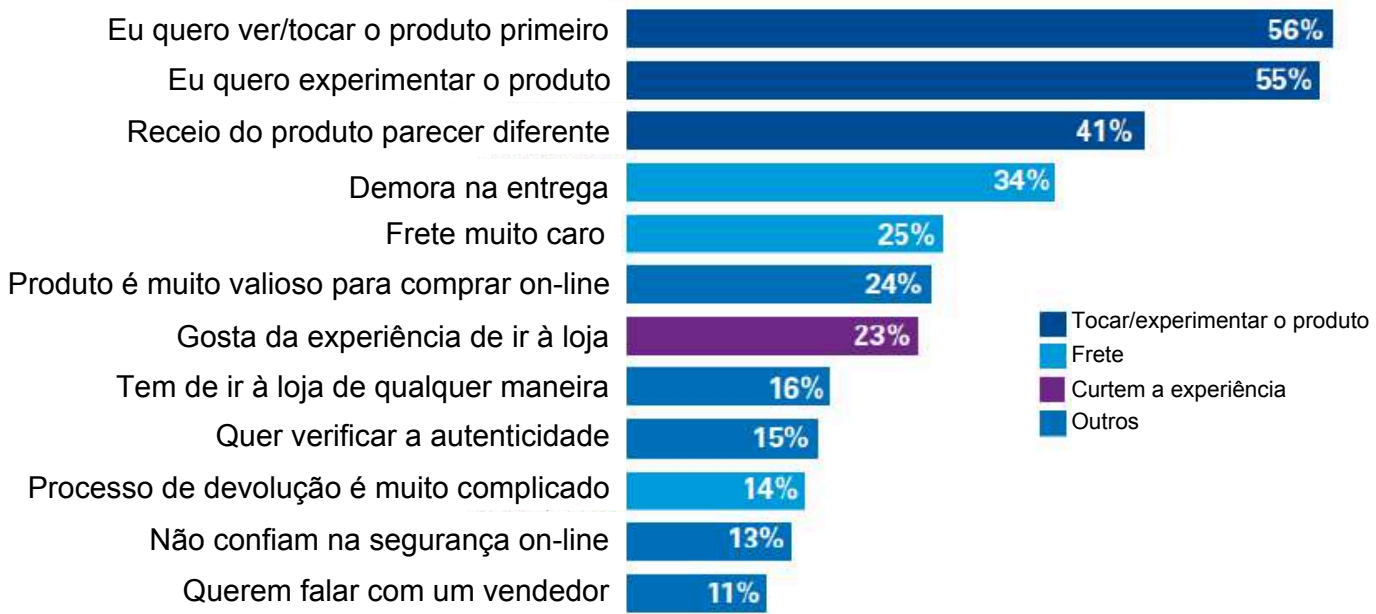

Figura 3.9 - Motivos para consumidores comprarem em lojas físicas. Fonte: (KPMG, 2017, p. 29)

3.10.

\section{Dificuldades ao comprar em sítios de e-commerce de vestuário}

Apesar de ser a categoria líder em número de pedidos, $84 \%$ dos usuários ficam desmotivados a comprar peças de vestuário on-line por não poderem experimentá-las ou vê-las fisicamente, aponta um relatório do SEBRAE-RJ ("Relatório de Inteligência", 2015, p. 2).

Lal e Sarvary (1999) argumentam que existam duas categorias de atributos de produtos: os digitais e os não-digitais. Os digitais são facilmente comunicados por meio da internet como o preço de um produto ou o tamanho de um livro, não há perda de informações quando comunicados desta forma. Estes atributos também podem incluir informações adquiridas previamente pelos usuários ao terem contato direto com o produto em alguma visita à loja física.

A segunda categoria, a de atributos não-digitais, são aqueles que só podem ser avaliados por meio do contato físico com o produto. No âmbito do vestuário, a textura e o fit, ajuste/tamanho em português, são características chaves que só podem ser verificadas por meio de um contato tátil e físico com o produto. Outros atributos não-digitais são o cheiro e o paladar de um vinho ou de flores, por exemplo. Portanto, o fit de uma camisa ou a aparência de um par de óculos, quando apresentados ou descritos on-line, podem introduzir incertezas significativas para determinados consumidores. 
Logo, dependendo do canal utilizado, os consumidores podem não ter informações completas antes de realizarem uma compra. Anderson, Hansen e Simester (2009, p. 406), por exemplo, percebem que “[...] o fit não é totalmente observado pelo cliente antes da compra ... [nas] configurações de varejo onde os clientes escolhem de um catálogo ou de um sítio na internet sem poder inspecionar completamente o produto". "Uma inspeção completa" é, naturalmente, muito importante para alguns clientes quando o produto possui atributos não-digitais. Consequentemente, a incapacidade dos consumidores de tocar e sentir produtos com atributos não-digitais antes de comprar por meio de catálogos ou on-line pode:

1. Atuar como dissuasor para a compra; e

2. Aumentar os custos operacionais se eles devolverem os produtos depois de experimentar uma discrepância entre a expectativa e a realidade (LAL; SARVARY, 1999).

Do ponto de vista do design, quando um produto não atende às expectativas de um usuário contribui para uma UX negativa. A falta de informação e da interação física com o produto é uma das principais barreiras à compra de moda on-line. Como peças de vestuário requerem um contato multissensorial, verificase que essa falta de contato direta pode levar a um menor satisfação do consumidor no processo de compras e a uma maior percepção de risco (BLÁZQUEZ, 2014).

\subsection{1 .}

\section{Omnichannel}

Por causa do crescente uso de novas tecnologias no varejo, os hábitos e expectativas de compra também estão sofrendo mudanças. Surge um novo consumidor usuário de múltiplos dispositivos e telas, ele está mais bem informado e demanda marcas que adotem uma estratégia omnichannel (JUANEDAAYENSA; MOSQUERA; MURILLO, 2016), ou seja, que ofereça diversos canais de contato com uma marca, tanto on-line quanto off-line. Talvez a estratégia omnichannel seja uma forma de oferecer aos usuários as vantagens tanto dos canais on-line quanto dos canais off-line, uma vez que os mundos real e o virtual 
concorrem entre si e ao mesmo tempo se complementam, torna-se lógico entrelaçá-los, onde um for mais fraco, o outro será mais forte (BELL, 2016).

A ISO-9241-210 determina que UX é uma consequência da imagem da marca, apresentação, funcionalidade, desempenho do sistema, comportamento interativo e capacidades de atendimento do sistema interativo, o estado interno e físico do usuário resultante de experiências anteriores, habilidades e personalidade e o contexto de uso. A UX omnichannel aborda a jornada do usuário como um todo: sua transição entre os diferentes canais (loja física, sítio on-line, telefone, etc.) e sua habilidade de transitar suavemente entre eles (FLAHERTY, 2017). Os novos consumidores esperam que um serviço ou experiência, seja consistente, uniforme e integrado, independente do canal que eles usam; estão dispostos a alternar os canais - loja tradicional, on-line e móvel - dependendo de suas preferências, necessidades, da hora do dia ou da categoria do produto ou serviço (JUANEDA-AYENSA; MOSQUERA; MURILLO, 2016). A Google (2012) publicou um relatório sobre o comportamento dos usuários que utilizam múltiplos canais para realizar tarefas, eles podem começar uma compra em um desktop/laptop e concluí-la em um celular, por exemplo (Figura 3.10).

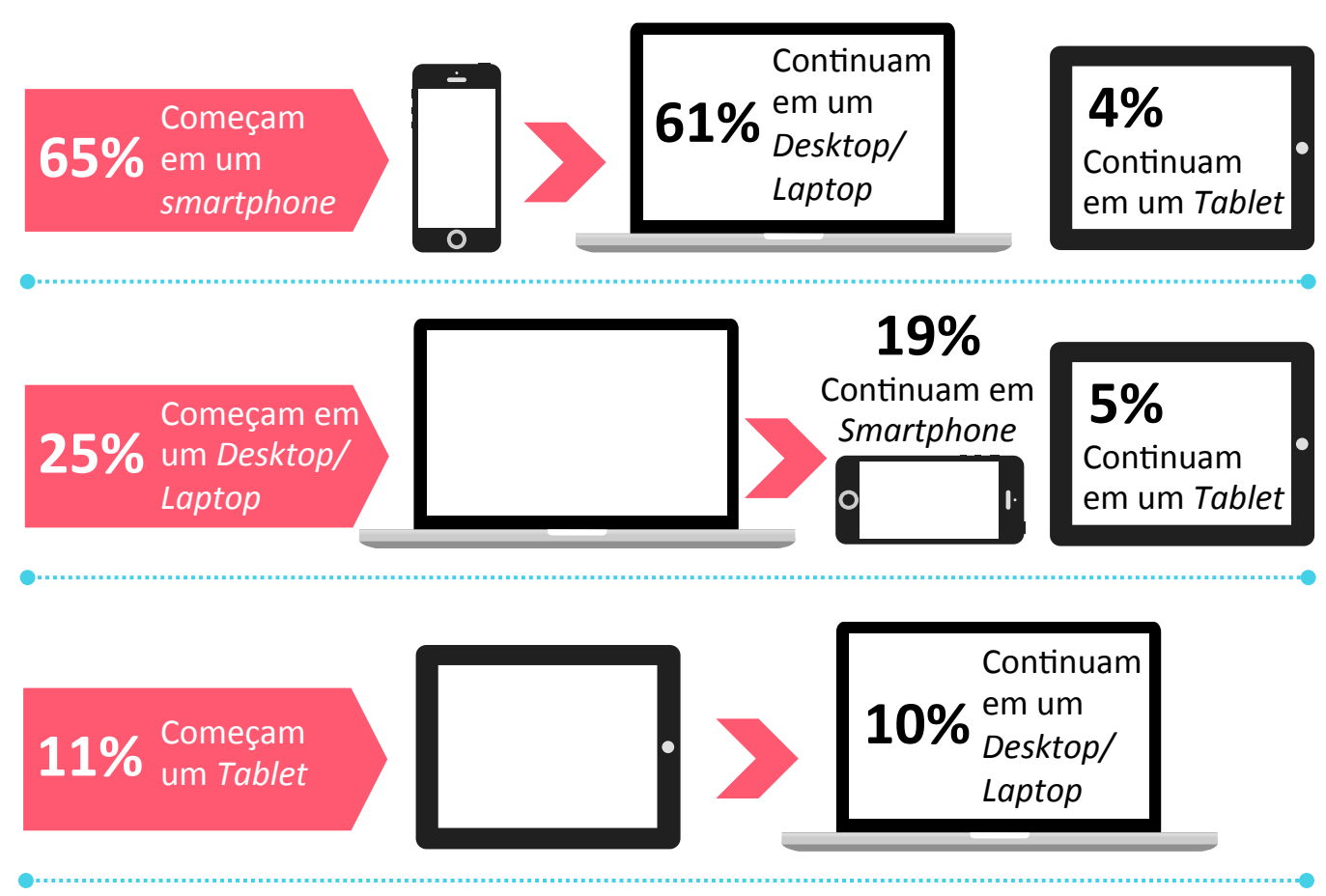

Figura 3.10 - Dispositivos usados para efetuar uma compra. Fonte: Adaptado de (GOOGLE, 2012, p. 43). 
Flaherty, (2017) cita cinco componentes que juntos criam uma estratégia de UX omnichannel bem-sucedida, ela deve ser:

1. Consistente: proporcionar uma experiência consistente, coesa e familiar em todos os canais

2. Otimizada: Criando experiências de canais individuais mais adequadas para esse dispositivo específico, restrições de canal e contextos de uso;

3. Seamless (sem emendas): tornar as transições entre os canais fácil e auxiliar os usuários a retomar uma tarefa do mesmo ponto onde eles pararam quando mudaram de um canal para outro;

4. Orquestrada: liderando com os clientes por meio das suas viagens individuais como interações e mensagens personalizadas corretas no momento certo;

5. Colaborativa: Enriquecendo a jornada do cliente, permitindo que os clientes aproveitem múltiplos canais ao mesmo tempo para melhorar a experiência geral do usuário (como permitir que os usuários façam login em um sistema bancário usando a autenticação de impressão digital em seus smartphones).

Muitas vezes, não é possível aos usuários completarem uma atividade em uma única sessão ou por meio de um único canal. Algumas das razões mais comuns pelas quais os usuários alternam entre canais incluem:

1. Quando existe uma interrupção ou mudança externa no contexto. Em algumas situações, os usuários não conseguem completar uma atividade porque são interrompidos. Por exemplo: ao realizar a compra de uma nova apólice de seguro de carro em um desktop um usuário pode perceber que é hora de buscar seu filho na escola. Ele pode continuar o processo de registro em seu smartphone enquanto espera no estacionamento.

2. A tarefa é mais adequada para outro canal. Os usuários geralmente mudarão de canal porque sua atividade tornou-se muito trabalhosa para o canal atual e mudar parece mais eficaz ou eficiente. Discutir uma cobrança na conta do celular em bate-papo on-line pode tornar-se um tanto trabalhosa à medida que tem de digitar-se todos os pormenores do ocorrido, talvez optar por ligar para a operadora para continuar a discussão por telefone, seja a opção mais adequada.

3. A atividade exige a mudança de canal. Algumas atividades por natureza exigem que os usuários utilizem diversos canais para completá-las. Por 
exemplo, preparar uma refeição de uma receita on-line pode exigir múltiplos canais. Um usuário pode começar a tarefa no desktop para escolher a receita, em seguida, ir para o aplicativo móvel enquanto compra a lista de ingredientes no mercado e terminar na cozinha em um tablet para que possa consultar a receita enquanto a prepara (FLAHERTY, 2017).

O contexto omnichannel pode afetar o grau de influência que a necessidade de segurança exerce nos consumidores, um fator importante no e-commerce, oferecer a opção de pagamento tradicional diminui o efeito do risco percebido. As lojas que adotam este tipo de estratégia têm a oportunidade de atrair consumidores mais conservadores que têm uma percepção de risco mais acentuada (JUANEDAAYENSA; MOSQUERA; MURILLO, 2016).

\subsection{2 .}

\section{Observações sobre o capítulo 3}

Este capítulo tratou de esclarecer as diferenças entre e-business e ecommerce, apresentou as diferentes modalidades existentes no e-commerce. Ademais abordou questões acerca da usabilidade e experiência do usuário neste canal on-line. E finalmente, discutiu-se a tendência mais popular entre os varejistas atualmente, a estratégia omnichannel.

O capítulo a seguir irá expor tópicos a respeito da moda e vestuário necessários para a compreensão de alguns aspectos acerca das etapas práticas desta dissertação (Capítulos 5, 6 e 7). 


\section{Moda, modelagem, medidas e corpo: uma apresentação}

O capítulo 3 abordou alguns aspectos sobre o e-commerce relevantes para este estudo, assim como: os principais conceitos, panoramas mundial e nacional, entre outros. No capítulo a seguir serão discutidos e apresentados, de maneira genérica e não aprofundada, conceitos de moda e indumentária e também aspectos do e-commerce de vestuário para a melhor compreensão e análise dos resultados dos métodos e técnicas de pesquisa que serão discutidos nos capítulos 5, 6 e 7 .

\section{1.}

\section{A moda como uma forma de comunicação}

A palavra fashion em inglês segundo o Oxford English Dictionary (2012), remete a palavra factio, que significa fazendo ou fabricando, e mesmo ao verbo facere, que significa fazer fabricar; também etimologicamente à palavra fetiche, uma vez que facere é a sua raiz. E nesse sentido pode afirmar-se que os produtos de moda e da indumentária são os produtos mais alçados à categoria de 'fetiche' entre os fabricados e consumidos pela sociedade capitalista (BARNARD, 2003).

Sobre a palavra moda, Oliveira (2002, p. 127) conceitua:

O sentido inicial do termo latino modus permaneceu no vocábulo francês mode, que aparece no século XV. Esse vocábulo - moda em português -, define as maneiras de conduta, o jeito de fazer, o estilo, a adoção de um uso vestimentar ou de uma outra voga proclamada como a do momento, quer essa seja a de um modo de fazer política, a do esporte da onda, a do que comer, quer a de onde fazer plástica turismo, divertir-se, uma vez que, na atualidade, quase nada escapa de ser tomado pelas indústrias de imposição de modos, ou de modismos, preestabelecidos para vigorar em determinado setor da sociedade, em dadas circunstâncias espaçotemporais.

O vestuário ocupa um espaço que, por sua importância econômica e social, foi ampliando o seu domínio para muito além das fronteiras da vestimenta. A moda envolve globalmente modos de conduta, estilos de vida, formas de gosto, correntes de ideias e de opiniões que caracterizam grupos, definindo-os e 
localizando-os em determinado período histórico e contexto, marcando-os em termos sociais, econômicos e culturais (OLIVEIRA, 2002). No contexto desta pesquisa a moda é abordada como uma forma de comunicação, seja no aspecto pessoal ou coletiva, tal como discutida nos livros de Barnard (2003) e Davis (1992). Por ela os indivíduos buscam distinguir-se na sociedade, uma vez que por meio da roupa comunicam seu estilo de vida, modo de viver, constroem sua imagem e identidade (ROBERTO; AVELAR, 2015) . “[...] embora o que as pessoas usem e como elas as usam pode, de fato, revelar muito quanto à sua posição social, esta não é a coisa mais importante comunicada" (DAVIS, 1992, p. 60)

Barnard (2003 p.64) esclarece:

[...] a moda, o vestuário e as roupas são artefatos, práticas e instituições que constituem as crenças, os valores as ideias e as experiências de uma sociedade. De acordo com esse ponto de vista, moda, roupa e indumentária são meios pelos quais as pessoas comunicam não só coisas, tais como sentimentos e humores, mas também valores, esperanças e crenças dos grupos sociais a que pertencem.

$\mathrm{O}$ autor lista entre as funções da moda: proteção, pudor e encobrimento, impudor e atração, comunicação (expressão individual, indicação de importância social ou status, definição do papel social, definição da importância econômica ou status, manifestação de símbolo político, condição mágico-religiosa, comunicação ritos sociais, lazer) (BARNARD, 2003). Com base nestas funções é possível considerar-se o vestuário como elemento fundamental em uma cultura, por exibirse como linguagem e por caracterizar-se pelas particularidade que assume em determinados contextos (CASTILHO, 2002).

Ademais, destaca-se a importância do ambiente para a interpretação da moda, deve ser observada quando inserida em um determinado meio social, no qual se manifesta como uma das mais espetaculares e significativas formas de expressão presentes no processo cultural, configurando-se plenamente como meio de manipulação, persuasão, sanção, ação ou performance e, por conseguinte, articulador de diferentes tipos de discursos: políticos, poético, amoroso, agregador, hierárquico, etc. (CASTILHO, 2002, p. 71).

Davis (1992, p. 9 ) esclarece:

[...] estilos de roupa e modas não significam as mesmas coisas para todos os membros de uma sociedade ao mesmo tempo e que, por isso, o que é usado se presta facilmente a uma confirmação simbólica dos limites de classe e status na sociedade. 
O significado de certas tendências manifestadas por meio do vestuário depende inteiramente da identidade de quem o usa, assim como da ocasião, o lugar, a companhia e ainda do ponto de vista e do humor do usuário. Os significados da roupa são dependentes da cultura na qual estão inseridos (DAVIS, 1992).

Por meio da roupa comunica-se algumas coisas sobre o indivíduo, e em um nível coletivo isso o posiciona simbolicamente em um determinado universo de reivindicações de status e estilos de vida (DAVIS, 1992). Já identificado por Simmel (2005, apud ROBERTO; AVELAR, 2015) em seu estudo sobre a psicologia da moda, quando aponta duas necessidades contraditórias no homem; a de integração que o faz ser igual aos outros, e a de singularidade. A maneira como nos vestimos ou nos adornamos está vinculada à necessidade do sujeito edificar uma imagem que corresponda aos seus anseios pessoais assim como à maneira como é percebido socialmente (CASTILHO, 2002).

Em suma, a moda é um modo de comunicação e a maneira como a consumimos é subjetiva, por vezes não somos capazes de expressar exatamente o significado por detrás do que vestimos. Estamos tão intimamente ligados às roupas que por vezes "as colocamos por algumas mesmas razões por que falamos" (BARNARD, 2003, p. 80). Logo, o processo de compra de uma peça de roupa, envolve diversos elementos subjetivos e intrínsecos relacionados ao conceito de vestir-se.

Para fins desta pesquisa, será abordado o segmento da moda que diz respeito ao vestuário ready-to-wear ${ }^{6}$ feminino.

\subsection{1.}

\section{Mercado de moda no Brasil}

O Brasil é um dos principais produtores mundiais de artigos confeccionados (COSTA; ROCHA, 2009). Devido à competitividade nacional e internacional a indústria de confecções teve de reestruturar-se, este processo resultou na terceirização da produção como meio de agilizar-se (ROSA, 2011).

\footnotetext{
6 Ready-to-wear: (masculino e feminino) Período: meio do século 20 em diante. O termo em inglês para prèt-âa-porter (francês); as coleções baratas desenhadas por marcas de moda em todo o mundo. No entanto, o termo é frequentemente aplicado a todas as roupas compradas prontas (CUMMING; CUNNINGTON; CUNNINGTON, 2010). O segundo significado será adotado nesta dissertação.
} 
A Região Sudeste é a maior produtora de itens provenientes da cadeia têxtil e de confecção do vestuário, com destaque para o Estado de São Paulo que ocupa o primeiro lugar do país (ROSA, 2011).

No Sul, Santa Catarina é um dos polos têxteis mais avançados da América Latina e, nacionalmente, possui a maior inserção de artigos de malha e linha lar no mercado internacional (ABRAVEST, 2016).

O Nordeste, em especial o Ceará, tem se desenvolvido em consequência do deslocamento de grandes empresas que receberam incentivos fiscais e benefícios de infraestrutura por causa do interesse governamental de estabelecê-las em seu território, resultando em um aumento de sua relevância no cenário internacional de produção e consumo da cadeia têxtil e de confecção do vestuário (ROSA, 2011).

Segundo o Relatório Setorial da Industria Têxtil Brasileira - Brasil Têxtil 2016, o setor de vestuário e têxteis produziram cerca de R\$ 131 bilhões em 2015. Este montante representa uma participação da cadeia têxtil brasileira na indústria de transformação de $5,8 \%$ do faturamento nacional. O Sudeste representa $48,7 \%$ e o Sul 28,5\%, deste faturamento (ABRAVEST, 2016).

Após dois anos seguidos de recessão, a indústria têxtil e de confecção dá sinais de recuperação em 2017. Dados mostram uma alta de 1\% na produção de vestuário contra queda de 6,7\% em 2016. A produção de têxteis também indica um crescimento de $1 \%$ contra $-5,3 \%$ no ano anterior. A perspectiva é a de que o faturamento do setor têxtil e de confecção brasileiro seja de R $\$ 135$ bilhões (US\$ 40,2 bilhões), o que significa um aumento de 4,6\% em relação a 2016 (ABIT, 2017b).

De acordo com o SINTEX (2017) (Sindicato da indústria de fiação, tecelagem e vestuário de Blumenau), o Brasil exportou um total de U\$ 1.358.007.590 em produtos têxteis, entre janeiro e setembro de 2017. A perspectiva do setor têxtil e de confecção para 2017 é a geração de 10 mil postos de trabalho, ante a perda de 125 mil empregos nos anos de 2016 e 2015, sendo 25 mil e 100 mil, respectivamente (ABIT, 2017b). Em 2014 o setor têxtil no Brasil era responsável por 1.6 milhões de empregos (SINTEX, 2015) em 2016 por 1,5 milhão de empregados diretos. É $2^{\circ}$ maior empregador da indústria de transformação $(16,7 \%)$, perdendo apenas para o setor de alimentos e bebidas (ABIT, 2017a).

Segundo dados da ABIT (2017b) o setor têxtil teve uma produção média de confecção de 5,4 bilhões de peças; (vestuário/meias e acessórios/cama, mesa e banho) em 2016 com um número de 29 mil empresas formais em todo o País. 
Estes dados posicionam o Brasil como o quarto maior parque produtivo de confecção do mundo e o quinto maior produtor têxtil. Também é o segundo maior produtor e terceiro maior consumidor de denim, além de ser o quarto maior produtor de malhas do mundo. O Brasil é, ainda, a última cadeia têxtil completa do Ocidente, desde a produção das fibras, como plantação de algodão, até os desfiles de moda, passando por fiações, tecelagens, beneficiadoras, confecções e varejo (ABIT, 2017a).

\subsection{2.}

\section{Panorama do e-commerce de vestuário brasileiro}

Como apresentado no capítulo 3, o segmento de moda e acessórios no Brasil foi o $1^{\mathrm{o}}$ colocado em volume de pedidos realizados por meio da internet, $14,8 \%$ do total, e $6^{\circ}$ em volume de faturamento, representa $6,4 \%$ dos $\mathrm{R} \$ 21$ bilhões movimentados por transações on-line de vendas de bens de consumo no primeiro semestre de 2017 (E-BIT, 2017b).

De acordo com o último relatório Webshoppers (E-BIT, 2017b), no Brasil, 25,5 milhões de consumidores fizeram pelo menos uma compra virtual no primeiro semestre de 2017. Segundo o mesmo relatório, a participação feminina e masculina (Figura 4.1) foi praticamente igual 50,04\% e 49,96\% respectivamente. Porém, no segmento de moda e acessórios esta distribuição é diferente, o público feminino é maioria, representa $66,4 \%$ do total de compradores (ATLAS, 2017).

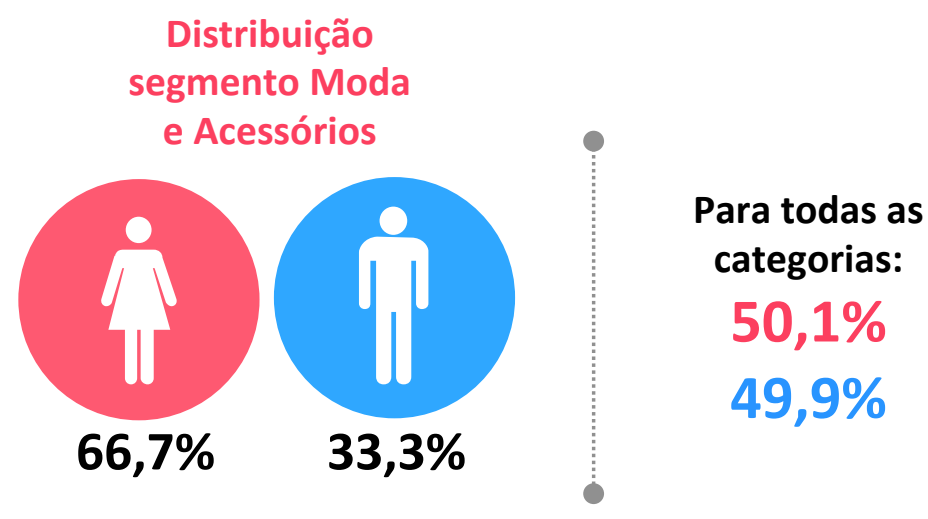

Figura 4.1 - Distribuição por gênero. Fonte: adaptado de (ATLAS, 2017). 


\section{2.}

\section{Modelagem}

O processo de produção industrial de peças do vestuário envolve diversas etapas, da concepção até a finalização do produto e a comercialização ao usuário final. Dentre estes estágios encontra-se a modelagem, que exige do profissional, o modelista, conhecimento das medidas e das proporções do corpo humano. A aplicação dessas medidas e da padronização de numerações são fatores fundamentais para o sucesso comercial de um produto de moda (ALVES; GRUBER, 2011).

A modelagem pode ser definida como a "transposição de medidas de uma realidade tridimensional (3D do corpo humano) para uma realidade bidimensional (2D para cortar o tecido)" (ROSA, 2011: p. 52). Refere-se ao desenvolvimento do modelo da peça de vestuário sobre uma base, adicionando detalhes e efeitos que são transformados em moldes (ROSA, 2011); estes são diagramas geométricos que representam as partes do modelo da roupa, oriundos da modelagem, que servirão como gabarito de orientação para o corte do tecido (SILVEIRA, 2003, 2011). A modelagem tem como objetivo, adaptar a coleção à produção, por meio do desenvolvimento dos moldes.

A elaboração da base é a primeira etapa no processo da modelagem e é definida a partir da ficha e do desenho técnico que são elaborados fundados na criação do estilista, nesta etapa é escolhida a base que melhor se adapta ao modelo que será desenvolvido. No âmbito da modelagem industrial, a base é traçada usando como referência medidas padronizadas, de acordo com a anatomia do corpo humano. Na Figura 4.2, a título de exemplo, a linha 6-7 é a medida de busto e a 3-4 a de cintura, foram traçadas utilizando as medidas do tamanho 40 tendo como referência uma tabela pré-determinada. Estas devem ser exatas aos contornos do corpo, pois sobre ela será desenvolvida a modelagem, que dará origem aos moldes que servirão para a posterior reprodução do modelo (ROSA, 2011).

Já na modelagem sob medida, a base será traçada utilizando as medidas tiradas da pessoa para a qual está desenvolvendo-se o modelo. Nesta dissertação serão abordados aspectos relativos à modelagem plana e à produção industriais. 


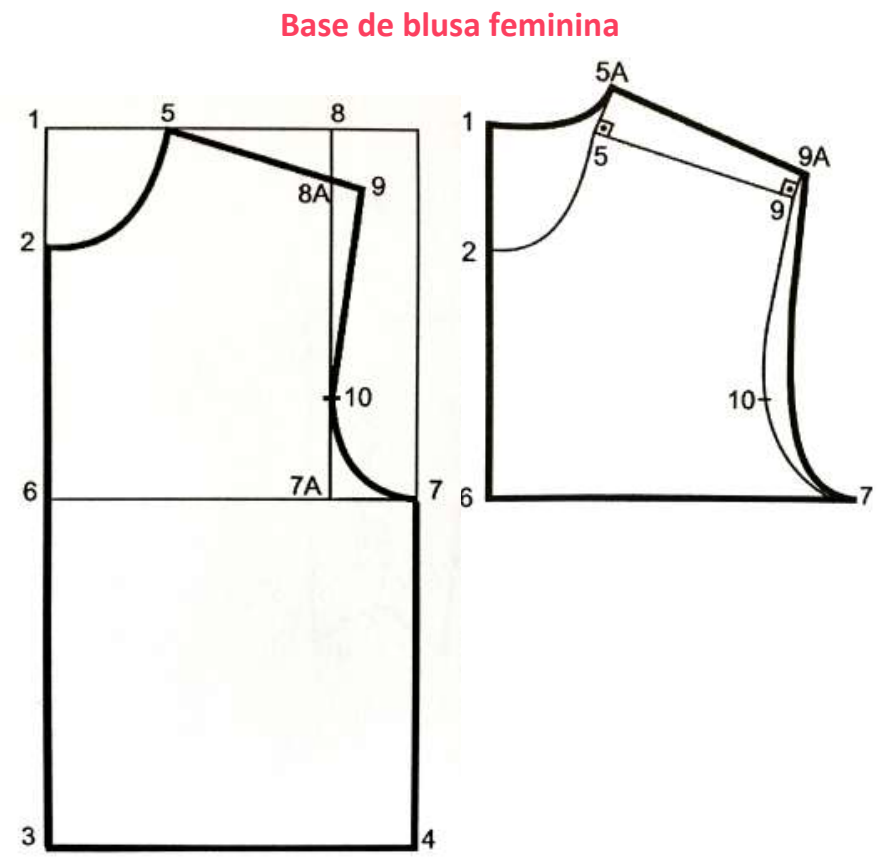

Figura 4.2 - Exemplo de base de blusa feminina. Fonte: (CAVALHEIRO; SILVA, 2003, p. 24-25).

Ampliando essa definição, a modelagem é a técnica responsável pelo desenvolvimento das formas da vestimenta, transformando materiais têxteis em produtos do vestuário (SILVEIRA, 2011).

Cabe ao modelista, por sua imaginação e capacidade de observação, ser capaz de adaptar, transformar e criar moldes utilizando como ponto de partida uma família ou bloco de moldes base (ARAÚJO, 1996).

$\mathrm{Na}$ modelagem, a segunda etapa do processo de construção da roupa (LEITE; VELLOSO, 2004), torna-se necessária a adoção de uma tabela de medidas para o desenvolvimento dos moldes do modelo. Uma vez utilizada, ela permeará por todo o processo da construção das peças. Caso esta tabela não obedeça um padrão, ou que não seja adotada uma única tabela, haverá uma diferença entre tamanhos equivalentes de uma mesma coleção.

Heinrich (2007, p. 12), alerta:

Se você terceiriza o processo de modelagem, é importante fornecer ao modelista freelancer a sua tabela de medidas padrão ou suas caixas de modelagem.

Em seu livro, Modelagem \& Técnicas de Interpretação para Confecção Industrial (HEINRICH, 2007b), a autora supracitada comenta: a modelagem plana possui como ponto de partida, a definição das medidas, que devem ser retiradas das tabelas de medidas e o traçado dos moldes básicos, já aprovado, e 
revisado, produzindo a forma anatômica das dimensões do corpo humano, com base nas linhas e nas regiões do busto e do quadril.

A falta de uma referência padrão de medidas a serem seguidas pela indústria têxtil, leva a um problema que afeta a cadeia de produção das peças de vestuário: denominado nesta dissertação como a disparidade das medidas, conceito abordado no item 4.4.2 mais adiante neste capítulo.

\section{3.}

\section{Caimento e vestibilidade}

A fim de esclarecimento deve-se definir os termos vestibilidade e caimento para melhor compreensão dos critérios adotados para a elaboração das tarefas do teste de usabilidade descritos no capítulo 6 desta dissertação. O primeiro, vestibilidade, wearability, vem sendo usado por diferentes autores, inclusive os citados nesta dissertação, ao se referirem ao uso ergonômico da roupa, segundo Pereira e Bezerra, (2011). As autoras advertem que a menção ao termo vestibilidade nem sempre vem acompanhada de uma definição esclarecedora por parte dos autores. Em vez disto, há uma interpretação individualizada sobre o efeito da modelagem, da antropometria e dos problemas identificados em testes com peças piloto.

As autoras citadas comentam que uma associação próxima da ergonomia relacionada a este termo foi encontrada no trabalho de Gersak (2014), para a qual:

Um critério principal de vestibilidade pode ser definido como a capacidade de se mover com a roupa sem esforço, a roupa deve levar em conta as atividades do corpo humano, e não interferir em movimentos como caminhar, sentar, ficar em pé, flexionar, alongar. Deve ainda permitir que o corpo desempenhe atividade fisiológica normal o sangue deve circular, o corpo deve suar e respirar (GERSAK, 2014, p. $323)$.

A ABNT NBR 15800 (2009) e a ABNT NBR 16010 (2012) também adotaram o termo vestibilidade para tratar das referências e medidas dos corpos de bebês e dos corpos masculinos, respectivamente (PEREIRA, ROSIANE; BEZERRA, 2011).

Portanto, para um maior entendimento conceitual a presente pesquisa, adotou o termo vestibilidade com base na definição de Gersak (2014).

O termo caimento está associado, como o nome sugere, à forma como o tecido 'cai' proporcionada pelo grau de flexibilidade, maleabilidade ou 
consistência do material têxtil (CHATAIGNIER, 2006). O caimento de um tecido interfere diretamente na silhueta configurada pelo produto (PALMIERI; RODRIGUES; SOUZA, 2017).

Convém afirmar que o caimento pode ser percebido visualmente e sofre alterações que estão ligadas especialmente a determinadas características dos materiais, como o peso, a espessura, a distorção, a elasticidade e a própria drapeabilidade $^{7}$. Tais características são consideradas por Aldrich (2013) como as que mais afetam o caimento e alteram a forma dos produtos. Acrescenta-se à estas características a maneira como o tecido é cortado, em viés ou reto (Figura 4.3) (DINIS; VASCONCELOS, 2014).

Especula-se que o caimento da roupa para os usuários não está somente associado às propriedades do tecido mas também, com à maneira em que a roupa "cai" no corpo.
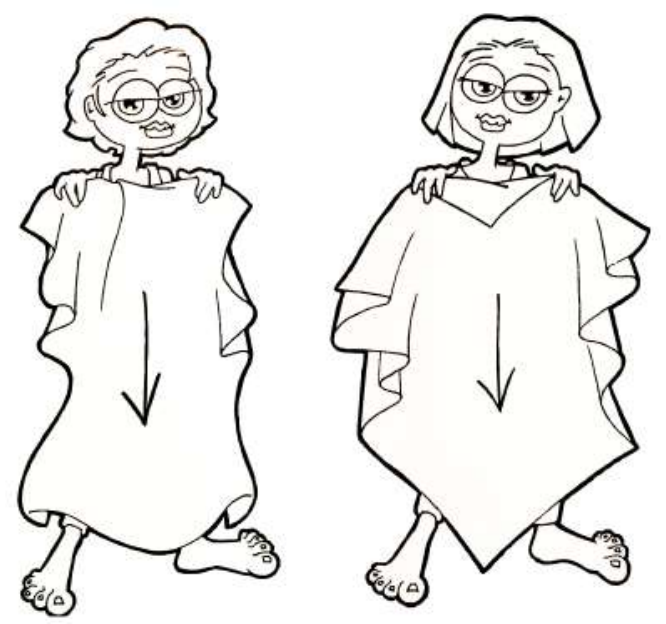

Figura 4.3 - Fio em linha reta (esq.) e fio em viés (dir.). Fonte: (DINIS; VASCONCELOS, 2014, p. 93).

\section{4.}

\section{Medidas}

\subsection{1.}

\section{Tabela de Medidas}

\footnotetext{
${ }^{7}$ a capacidade de formar curvas com dobras flexíveis (BREHM, 2011). O conjunto de características de uma superfície que inclui maciez, maleabilidade e flexibilidade (BREHM, 2011, apud Dicionário de Definições do Ramo têxtil, 2007).
} 
A tabela de medidas é um conjunto de medidas necessárias para a construção das bases de modelagem, são baseadas em médias calculadas a partir de medidas tiradas em um determinado número de pessoas (HEINRICH, 2007a). Ela é composta de valores que retratam medidas essenciais do corpo humano (ROLLIM; RADICETTI, 2009). A Tabela 4.1 é um exemplo de uma tabela de medidas elaborada a partir de um estudo antropométrico com pessoas da região do Sudeste do Brasil onde existe uma vasta variedade de corpos em consequência da migração para esta área do País.

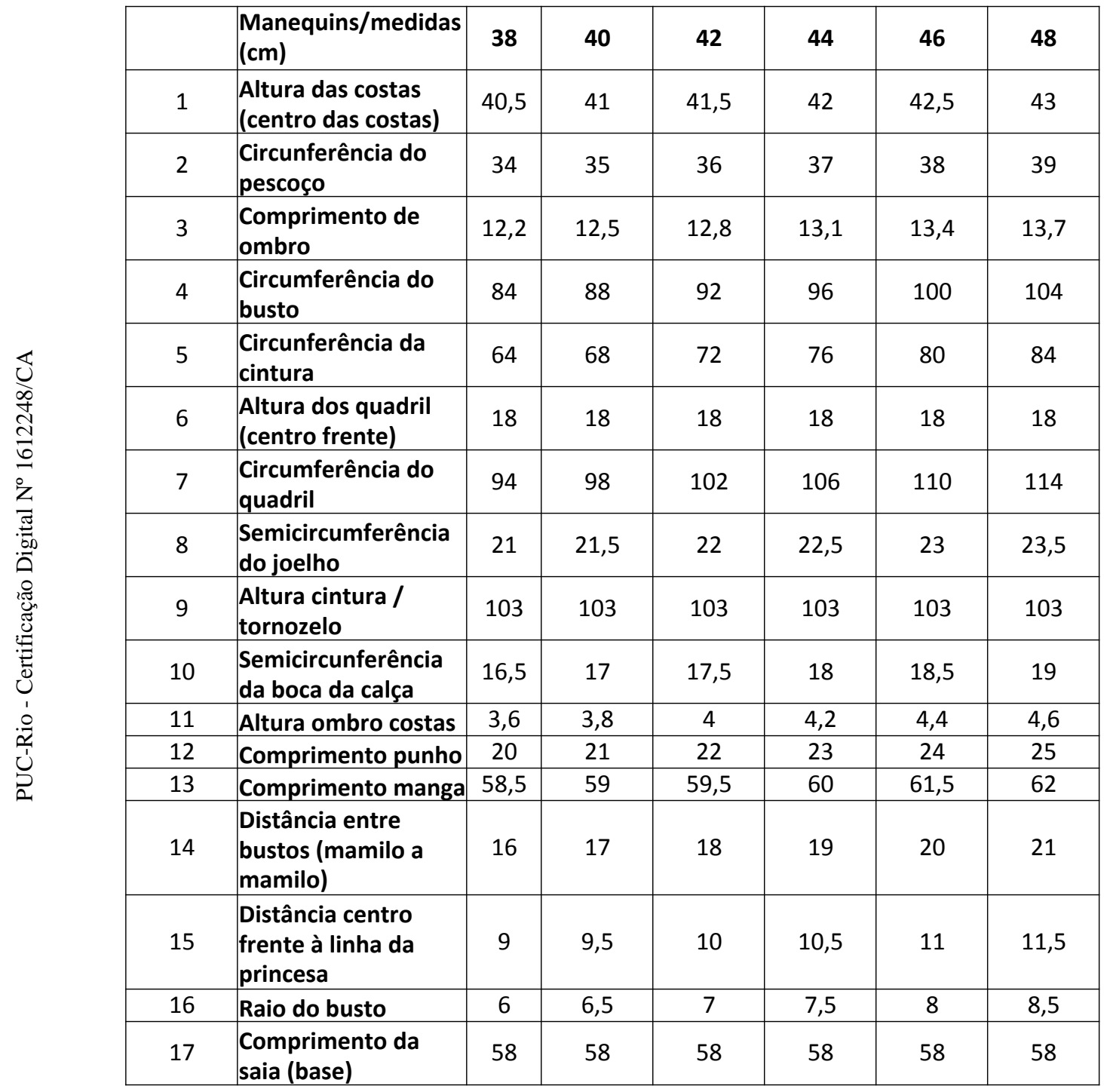

Tabela 4.1 - Exemplo de tabela de medidas. Fonte: (ROLLIM; RADICETTI, 2009, p. 9-10)

Encontra-se diferentes tabelas de medidas, elas variam de país para país e podem variar de acordo com o tipo físico da população. No Brasil, não existe um padrão de tamanho obrigatório para o vestuário, consequentemente, existem 
diferenças de tamanho entre as confecções, causando o que é denominado nesta dissertação como 'disparidade de medidas', discutida no próximo item. Por conseguinte, as grifes determinam suas próprias tabelas de tamanho, direcionadas ao seu público-alvo. Labat (2007) em seu artigo Sizing standardization discute que padronização pode contribuir ao fornecer informações confiáveis com base científica sobre as formas e tamanhos corporais que podem ser usados por confecções para o desenvolvimento de padrões de medidas para a fabricação de roupas. A autora cita que teoricamente as roupas elaboradas usando um sistema de dimensionamento com base em dados antropométricos produzidos cientificamente fornecerão aos consumidores um produto em que possam confiar. Esta consistência pode reduzir a insatisfação com o ajuste, aumentar as compras, reduzir os retornos e aumentar os lucros dos produtores. Segundo uma revisão da literatura da autora, a incapacidade de muitos consumidores de encontrar um bom ajuste tem sido reconhecida como um grande problema na indústria de vestuário. Muitos estudos indicam que os consumidores estão insatisfeitos com o ajuste da roupa. Na verdade, é a maior reclamação acerca das roupas ready-to-wear.

O ideal seria estabelecer uma tabela-padrão oficial para as medidas fundamentais e auxiliares e outra da empresa, de acordo com sua segmentação de mercado (com características de seu público-alvo, adaptando as medidas complementares ao seu próprio padrão) (HEINRICH, 2007a). Porém, parafraseando Araújo (1996, p. 125): “Este assunto é controverso, sendo difícil obter o consenso dos confeccionadores no que respeita à normalização das medidas".

$\mathrm{Na}$ ausência de uma obrigatoriedade e de uma normatização as empresas de vestuário, considerando o público com as quais trabalham, vão determinar uma tabela de medidas-padrão, que utilizará para confeccionar suas peças. Da mesma forma, também determinará as medidas de aumento e diminuição entre os tamanhos (graduação).

As medidas básicas consideradas para determinar o código de variação são: busto, cintura e quadril. A constância entre esses três valores deve sempre ser mantida. O código da variação pode ser definido, considerando:

Tamanho geral do corpo: comumente usada em roupas amplas, a nomenclatura é: pequeno, médio e grande $(\mathrm{P}, \mathrm{M}, \mathrm{G})$. Nesse caso, o código de variação tem valor de $6 \mathrm{~cm}$; 
Relação proporcional do corpo: geralmente usada em roupas mais ajustadas ao corpo, a nomenclatura é pela numeração de $34,36,38,40,42,44$, 46, etc. Nesse caso, o valor do código é de $4 \mathrm{~cm}$;

Idade: no Brasil, é largamente usada para roupas infantis e infanto-juvenis. Usase a idade $2,4,6,8$, ou então $2,3,4,5$, etc., como nomenclatura. Para o infantil, a estrutura segue outros valores diferentes das do adulto, considerando-se o crescimento da criança nas diferentes faixas etárias;

Tamanho dimensional das partes do corpo: Geralmente usado em roupas, pode-se optar por um valor de 4cm (HEINRICH, 2007a).

\subsection{2.}

\section{Disparidade das medidas}

Os problemas relacionados aos tamanhos dos artigos de vestuário no Brasil oferecem uma série de fatores a considerar-se (DINIS; VASCONCELOS, 2014). A falta de padronização do processo de desenvolvimento de modelagem pode ser percebido claramente em produtos de uma mesma empresa. Gera-se confusão no estabelecimento de tamanhos das peças refletindo-se diretamente no processo de decisão de compra do consumidor. Existem casos de consumidores que adquirem produtos na mesma loja com variações de até três manequins (DINIS; VASCONCELOS, 2014). De uma forma geral existe a percepção que essa disparidade acontece mais no vestuário feminino. Segundo Chun (2007) as mulheres, relatam mais problemas que os homens, a autora argumenta que isto deve-se em parte à uma grande variedade de formas e de estilos disponíveis no vestuário feminino. Um outro motivo pode estar relacionado ao fato das roupas femininas serem mais ajustadas ao corpo e demandarem mais exatidão nas medidas no desenvolvimento das modelagens (ALDRICH, 2007).

Este cenário agravou-se com o processo de terceirização da produção de peças de roupas. É comum no Brasil as marcas entregarem sua produção a pequenas confecções que por sua vez não têm necessariamente um processo de padronização no desenvolvimento dos produtos (DINIS; VASCONCELOS, 2014). A falta de um padrão de medidas adotado entre marcas não é um problema nacional, em seu artigo Communication of sizing and fit, Chun (2007) discute a adoção de tabelas de medidas individuais advindas de diferentes modelos de prova e consequentemente cada marca 
tem roupas com tamanhos diferentes mesmo que na etiqueta esteja o mesmo número. A autora menciona o vanity sizing (medidas da vaidade) (CHUN, 2007) como uma fonte de problemas no setor de vestuário. Este refere-se à troca da etiqueta de tamanho dos artigos, desta forma o consumidor tem uma falsa impressão de que veste um manequim menor (DINIS; VASCONCELOS, 2014). É uma estratégia largamente utilizada para aumentar vendas, pois muitos consumidores não admitem usar certa numeração (BASTOS et al., 2010). Esta pode ser uma estratégia bem sucedida e ajudar a aumentar a fidelidade à marca, mas contribui diretamente para a confusão acerca das medidas (CHUN, 2007). Foi um ponto bastante discutido pelos especialistas nas entrevistas descritas no capítulo 5, referido como o 'fator psicológico das medidas'.

A antropometria é a área base para o estudo do homem com o objetivo de estabelecer padrões de proporcionalidade necessários para definir as medidas do vestuário (SILVEIRA, 2003). Quanto maior a precisão das medidas antropométricas utilizadas, tanto melhor será a vestibilidade da roupa, a adequação ao corpo e mobilidade dos membros (VITOR; NERY; MOREIRA, 2016). Por possuírem uma cartela de clientes variados, consequentemente, a variação de tamanhos entre indústrias também é variado. Consequentemente, sem um padrão antropométrico para a construção das bases de modelagem, as indústrias de confecção adaptam suas peças de acordo com o tipo físico do seu público-alvo (VITOR; NERY; MOREIRA, 2016). Na Figura 4.4, pode verificarse a disparidade das medidas de uma camisa tamanho P (pequeno) em 5 lojas diferentes: Ellus, Lança Perfume, Wee, Mandi e Cantão, mostrando diferenças de até 15 centímetros no comprimento de manga, por exemplo. A Figura 4.5 ilustra as diferenças entre as medidas contidas em 3 referências de modelagem existentes no Brasil; nos livros Modelagem Industrial Brasileira, Modelagem Plana Brasileira e da revista Figurino Moldes, assim como as de 4 empresas de vestuário; as malharias Malwee e Hering e dos sítios Dafiti e Privalia. No exemplo, tomou-se como base o tamanho 40, a medida da circunferência da cintura e a medida da largura das costas. Esta última, no livro de Modelagem Industrial Brasileira, é 15 centímetros menor do que no livro Modelagem Plana Brasileira. A Dafiti considera que uma circunferência de quadril entre 102-105 centímetros seja equivalente ao tamanho 40, enquanto a Privalia considera que uma circunferência entre 98-102 centímetros equivale ao mesmo tamanho. 


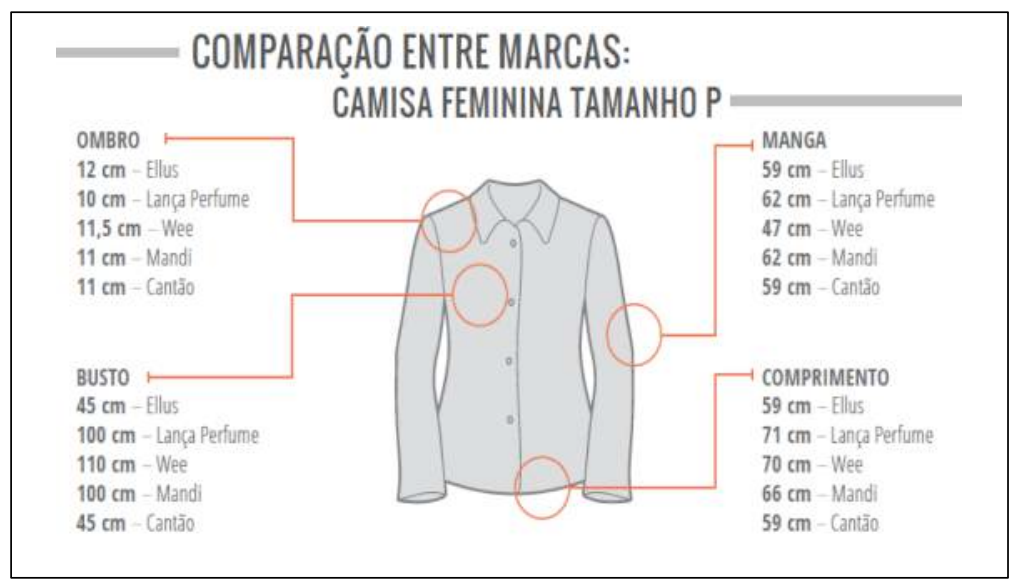

Figura 4.4 - Comparação entre marcas: camisa feminina tamanho P. Fonte: (SEBRAE, 2015, p. 2)

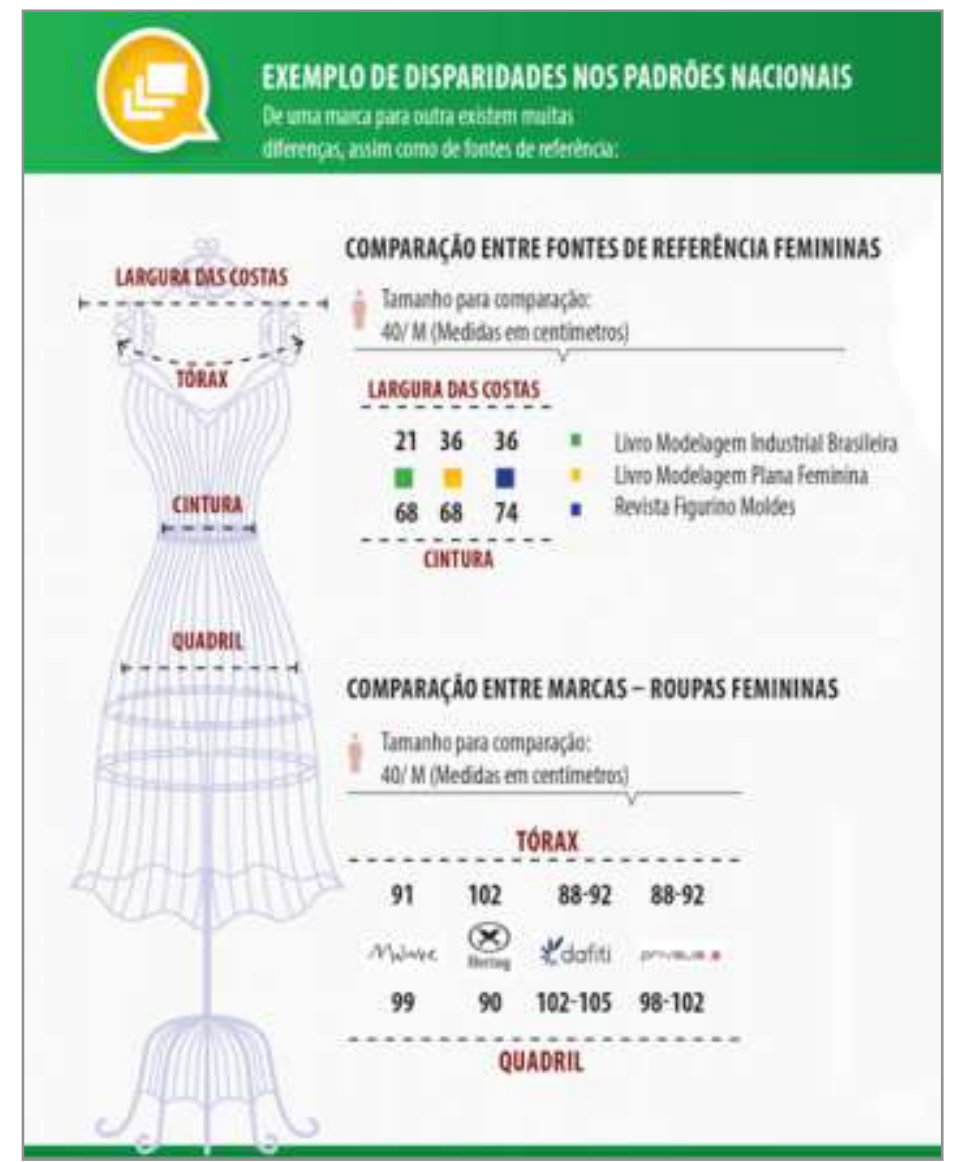

Figura 4.5 - Comparação de tamanhos entre referências e entre marcas. Fonte: (SEBRAE-RJ, 2014, p. 1)

Uma das maiores barreiras para a compra on-line de produtos relacionados à moda, é a falta de contato físico com o produto, as roupas têm textura, caimento, atributos difíceis de serem transmitidos por uma tela (BELL, 2016), são atributos não-digitais de um produto (LAL; SARVARY, 1999). Assim, o e-commerce deve 
assegurar no mínimo a mesma segurança que um consumidor possui ao comprar em um estabelecimento comercial tradicional (VITOR; NERY; MOREIRA, 2016).

\subsection{3.}

\section{NBR 13377 e NBR15127}

A falta de padronização de medidas no Brasil começa a ser abordada. A padronização de medidas e variáveis de tamanhos na indústria do vestuário torna-se importante para o processo de comercialização, refletindo-se no processo produtivo, pois facilita a definição precisa dos parâmetros técnicos que garantem o desempenho dos produtos, visando ao conforto antropométrico e melhor vestibilidade da roupa (DELFINO, 2014).

Com o intuito de fortalecer a cadeia de produção e comercialização dos produtos de moda, a ABNT - Associação Brasileira de Normas Técnicas propôs a NBR 13377 em maio de 1995, que visava padronizar os tamanhos de artigos do vestuário em função das medidas do corpo humano com objetivo de orientar os consumidores de artigo do vestuário na escolha dos tamanhos e assim normatizar algumas medidas referenciais do corpo humano para o vestuário (vide Apêndice 5 para uma lista de medidas referencias do corpo humano). Em decorrência da necessidade de atualizar as medidas de referência para produtos do vestuário de forma mais eficiente iniciou-se em 2006 uma revisão da norma citada e foi eventualmente cancelada em 2012 (ALVES; GRUBER, 2011).

Em 2004, a ABNT propôs a NBR 15127 com o objetivo de estabelecer procedimentos para definir medidas do corpo humano que pudessem ser utilizadas como base na elaboração de projetos tecnológicos, considerando diversas aplicações, dentre elas o vestuário (ALVES; GRUBER, 2011). Atualmente, as normas são de caráter voluntário, permitindo a cada empresa desenvolver ou adotar uma tabela voltada para o público que quer atingir.

Em seu artigo, Alves e Gruber, (2011) comparam as medidas propostas pela NBR15127 com referências de medidas adotadas por autores em seus livros de modelagem. A Tabela 4.2, baseada nos resultados da pesquisa das autoras, expõe este comparativo entre as medidas propostas pelos quarto autores selecionados por elas e pela NBR 13377 (as medidas que estavam divididas por 2 foram multiplicadas para facilitar a comparação). A última coluna apresenta a diferença 
entre a maior e a menor medida. Em alguns casos há uma diferença significativa entre as medidas, como observado no "Comprimento do tronco anterior à cintura", em que a variação chega a 6,5 centímetros. Aproximadamente metade das medidas mantém uma diferença igual ou menor que 2 centímetros.

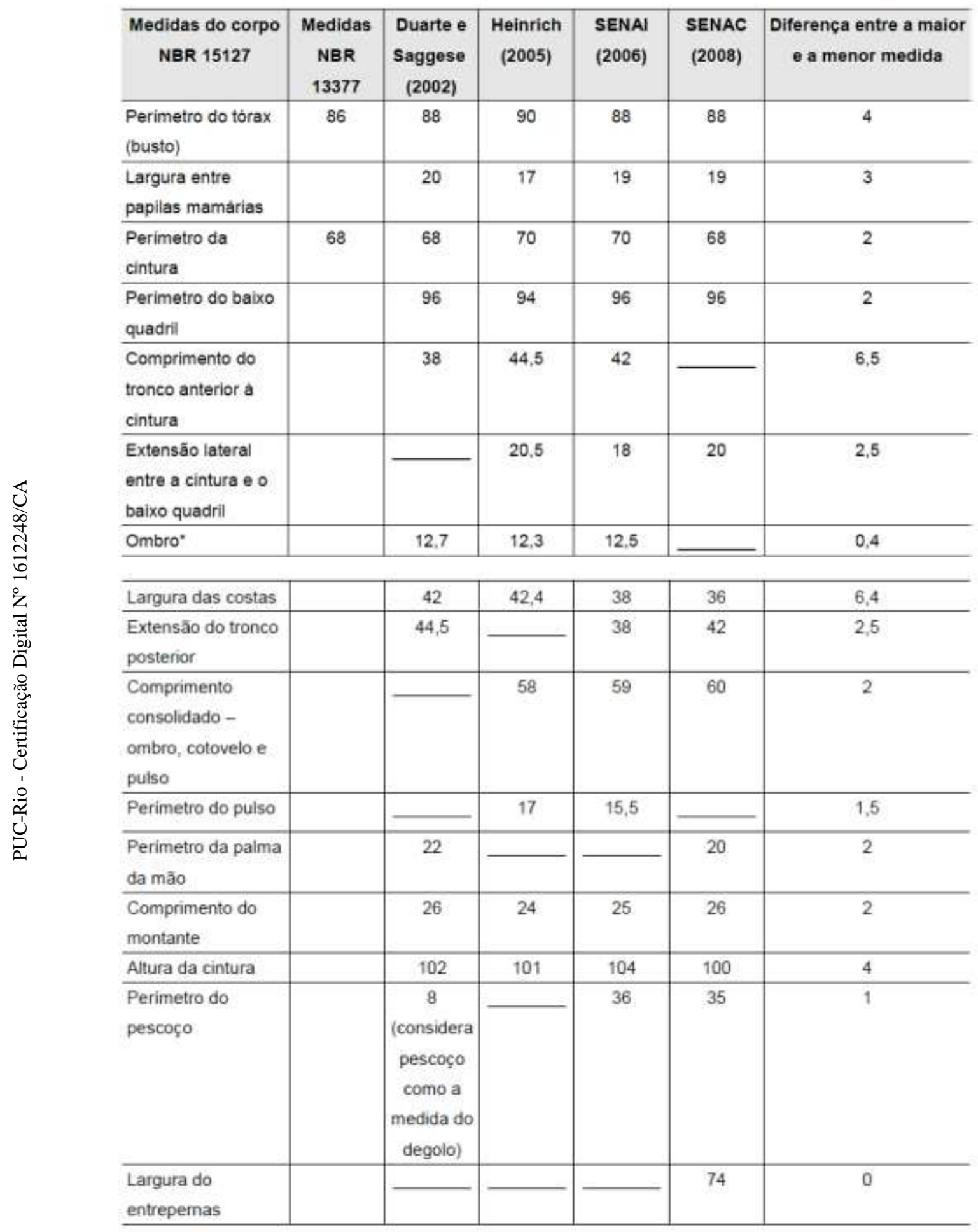

Tabela 4.2 - Comparativo de medidas. Fonte: (ALVES; GRUBER, 2011, p. 8-9). 
Em um outro estudo comparativo, entre os tamanhos de calças jeans, os autores Vitor, Nery e Moreira, (2016) encontraram uma diferença de até $14 \mathrm{~cm}$ entre o maior e menor comprimento de calças do tamanho 36 que foi usado como base da pesquisa.

Outra consequência da ausência de padronização no setor de vestuário, além das diferenças nas referências de tamanhos, é o uso de nomenclaturas diversas para descrever os mesmos tamanhos e termos técnicos para descrever medidas (ALVES; GRUBER, 2011; DINIS; VASCONCELOS, 2014).

Esta ausência de padronização pode causar interferências na comunicação entre os atores da indústria de vestuário, assim como entre eles e o usuário final.

\subsection{4.}

\section{Levantamento antropométrico SENAI-CETIQT}

O SENAI-CETIQT (Centro de Tecnologia da Indústria Química e Têxtil) concluiu em maio de 2017 um levantamento antropométrico denominado Pesquisa de Caracterização Antropométrica Brasileira, o SizeBR que teve inicio em 2009 (SENAI-CETIQT, [S.d.]; ZARUR; LUQUES, 2017). O intuito foi construir uma base de dados por meio da coleta das medidas e mapeamento das formas do corpo brasileiro utilizando um aparelho capaz de escanear o corpo humano, o bodyscanner. Segundo uma matéria do jornal O Globo ${ }^{8}$ (ZARUR; LUQUES, 2017) foram medidos 10 mil voluntários nas cinco regiões brasileiras, englobando 16 estados e 27 cidades. Destes, 64\% eram mulheres e 36\%, homens. Aproximadamente, 25 medidas foram estabelecidas para a construção de bases de modelagem. Esta base de dados poderá beneficiar diversos segmentos industriais entre eles o de vestuário. Estudos similares já foram feitos em diversos outros países como o SizeUSA, o SizeUK, acredita-se que o primeiro foi feito na década dos 1930 nos Estados Unidos (LABAT, 2007).

O estudo do SENAI-CETQT buscou responder as seguintes perguntas: Qual é a forma do corpo da população brasileira? Quantos são da mesma forma? Qual é a melhor segmentação da população para o desenvolvimento de um sistema de

\footnotetext{
${ }^{8}$ Ao ter conhecimento da material do jornal O Globo não havia disponível o documento oficial sobre o SizeBr.
} 
tamanhos? Como relacionar a forma do corpo com o sistema de tamanhos? Como ajustar os corpos padrão na modelagem do vestuário? O que pode ser feito para que os confeccionistas passem a utilizar um mesmo sistema de tamanhos? (BASTOS et al., 2010).

Para responder estas perguntas o SizeBr propôs:

- Mapear os diferentes biótipos masculinos e femininos, gerando manequins e tabelas de medidas atualizadas;

- Definir uma metodologia para aplicação dos resultados de medição do corpo humano, obtidos em pesquisa por amostragem;

- Sistematizar as informações coletadas;

- Estabelecer critérios técnicos para aplicação dos resultados;

- Estruturar uma metodologia de construção de bases de modelagem, utilizando os dados coletados;

- Criar um Laboratório experimental de vestibilidade;

- Desenvolver manequins com padrões brasileiros, que serão testados em empresas de confecção, e poderão ser utilizados na calibração de bodyscanners;

- Desenvolver Normas para construção das bases de modelagem;

- Desenvolver Normas para definição dos conceitos de funcionalidade e vestibilidade; $\mathrm{e}$

- Disponibilizar a base de dados obtidos no projeto para outros estudos (BASTOS et al., 2010).

Conforme o artigo do jornal O Globo (ZARUR; LUQUES, 2017), o SizeBR definiu tabelas de medidas masculinas e femininas para as cinco regiões brasileiras, divididas por biótipos.

Acredita-se que esta disparidade de medidas se dá pelo fato do Brasil não ter uma base de dados antropométricos. Apesar de as empresas trabalharem com públicos alvos diferentes, se houvesse alguma padronização e sistematização de manequins estes poderiam corresponder a algum nível mínimo. A inconformidade de tamanhos disponíveis no mercado nacional é um dos fatores que mais abalam a segurança do consumidor em adquirir um produto de vestuário (DINIS; VASCONCELOS, 2014), especialmente em sítios de e-commerce. 
Antes de comprar uma peça de vestuário, os consumidores determinam se esta atende às suas necessidades ao ler a etiqueta de tamanho ou os dados disponíveis em um catálogo ou em um sítio de e-commerce. A etiqueta fornece um código que deve se relacionar com as dimensões físicas do vestuário ou com as dimensões do corpo que são a base para dimensionar o vestuário. A etiqueta deve comunicar informações úteis ao consumidor, o auxiliando na seleção de uma peça de vestuário que se ajuste bem. O objetivo da padronização das designações de tamanho é consistência e precisão na rotulagem para que o consumidor seja poupado da frustração de experimentar muitas roupas para encontrar uma que se encaixe. Isto é especialmente importante para vendas de on-line (LABAT, 2007).

\section{5.}

\section{Tipos de corpos femininos}

Os corpos humanos são assimétricos, e nem sempre homens e mulheres vestem o mesmo manequim na parte superior e inferior do corpo, em outras palavras algumas pessoas pode vestir uma blusa M e uma saia G ou GG. Algumas pessoas têm a cintura mais marcada, outras menos, e isto é mais um fator a ser considerado no desenvolvimento de tabelas de medidas para uma população (a diversidade das formas dos corpos humanos foi um dos assuntos mais citados pelos especialistas de moda entrevistados e abordado no capítulo 5). Um dos objetivos do projeto SizeBR foi identificar os formatos dos corpos das mulheres brasileiras, por idade e região geográfica. Buscou-se como parâmetro de qualidade do estudo da forma do corpo da mulher brasileira a comparação com corpos de outras mulheres de outras nacionalidades (BASTOS; SABRÁ, 2014).

Para as mulheres, os biótipos existentes são: ampulheta (hourglass), ampulheta inferior (bottom hourglass), ampulheta superior (top hourglass), colher (spoon), triângulo (triangle), triângulo invertido (inverted triangle) e retângulo (rectangle). Esta categorização tem base em pesquisas norte-americanas realizadas para a caracterização de tipos físicos considerando a proporção entre busto, cintura, quadril e altura do quadril (BASTOS; SABRÁ, 2014). O SizeBR utilizou os mesmos critérios utilizados por Lee e outros autores (LEE et al., 2007). A Figura 4.6 ilustra os 7 biótipos. 


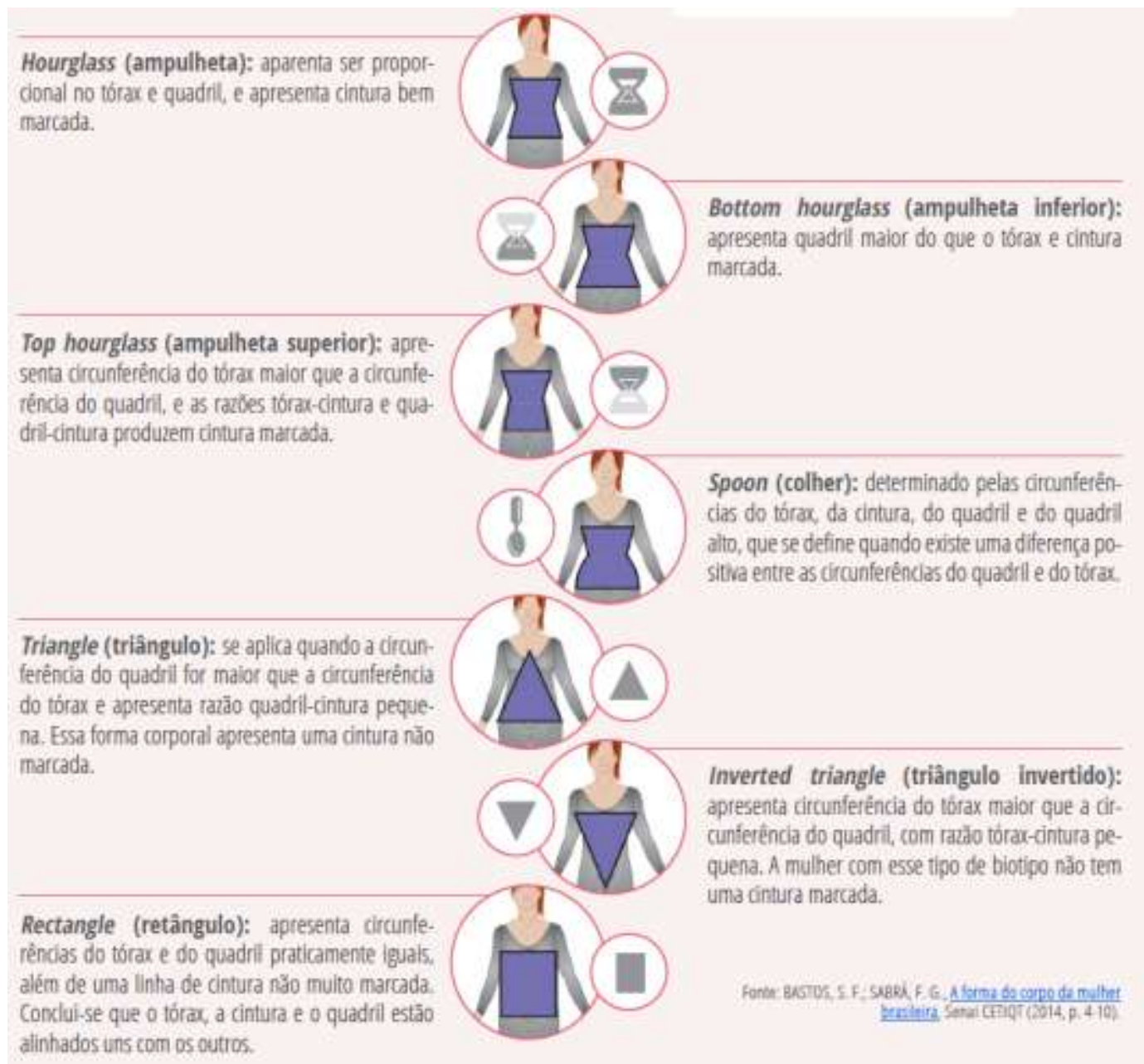

Figura 4.6 - Biótipos do corpo feminino. Fonte: (SEBRAE, 2015, p. 3) baseado em (BASTOS; SABRÁ, 2014).

No estudo do SENAI-CETIQT as mulheres de biótipo retângulo foram maioria, representando $76 \%$ da amostra, em seguida de biótipo triângulo (8\%), ampulheta $(6 \%)$, colher $(5 \%)$ e por fim de biótipo triângulo invertido (5\%). A Figura 4.7 mostra os biótipos mais comuns na Região Sudeste do Brasil, local onde foram realizados os testes de usabilidade descritos no capítulo 5 desta dissertação. 


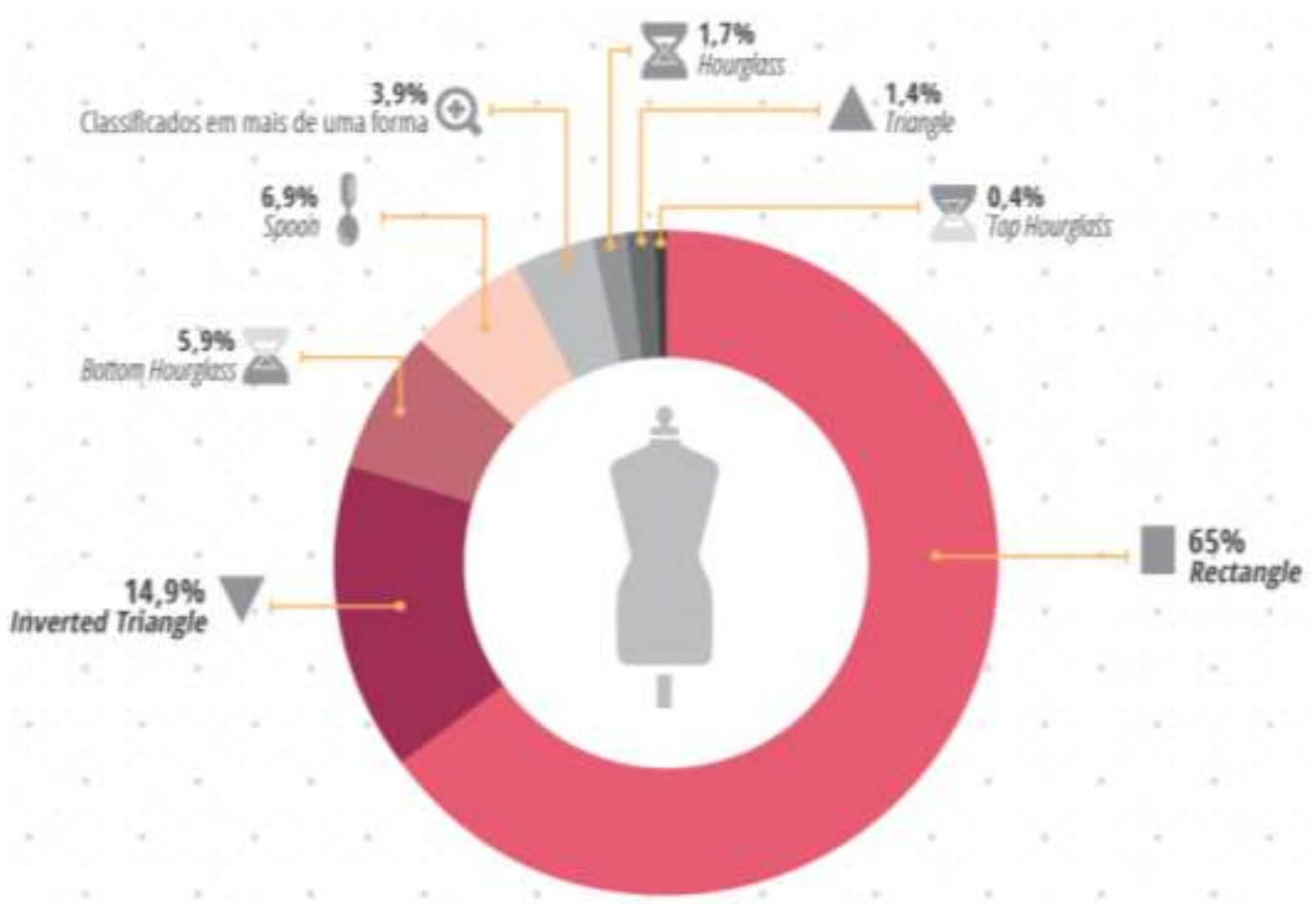

Figura 4.7: Distribuição da forma corporal das mulheres da Região Sudeste. Fonte: (SEBRAE, 2015, p.

4) baseado em: (BASTOS; SABRÁ, 2014).

\section{6.}

\section{Materiais têxteis}

Para entender a modelagem é preciso compreender a importância do papel dos materiais utilizados para a produção do vestuário, que combinados com o tipo de corpo e o caimento configuram a peça. Esta informação foi fundamental para o planejamento do Teste de Usabilidade (capítulo 6) e análise de seus resultados. O tipo de tecido tem ligação direta com a folga, tipo de corpo e modelagem, discutidos a seguir.

O processo têxtil inicia-se com o consumo de fibras têxteis para a fabricação de fios que posteriormente são transformados em tecidos. Existem dois tipos de fibras: as naturais, encontradas na natureza (a seda, o linho, o algodão, a lã, etc.) e as artificiais (a viscose, o acetato, o liocel, o modal) e sintéticas (poliéster, poliamida, elastano, etc.) fabricadas por processos químicos (MARTINS; LOPES, 2014).

Martins e Lopes (2014) explicam: uma vez pronto, o fio pode ser utilizado na fabricação de tecidos, que podem apresentar basicamente duas formas, a primeira empregando-se dois grupos de fios, um na vertical (fios de urdume) e outra na horizontal (fios de trama), formando um angulo de $90^{\circ}$ (Figura 4.10), o 
que o qualifica a ser chamado de "tecido plano". Alguns exemplos de nomes comerciais de tecidos plano são: popeline, tricoline, cambraia, organza, jeans, brim, gabardine, cetim e acetinados, veludos, tecidos felpudos como a toalha de banho, dentre outros.

A segunda forma são os tecidos de malha. Estes se diferenciam dos tecidos planos em função da forma com que os fios são entrelaçados (Figura 4.8), a forma de ligação entre os fios define as características das malhas:

- malhas formadas na largura do tecido (malhas de trama);

- malhas formadas no comprimento do tecido (malhas de urdume) (ABIT, 2011).

A laçada é o elemento fundamental dos tecidos de malha. Sua forma arredondada garante o excesso de fio, que proporciona a elasticidade, o bom caimento e a sensação de conforto que normalmente caracteriza todo e qualquer tecido de malha (MARTINS; LOPES, 2014). Na malharia de trama, basta um fio para alimentar o tear, onde são produzidos os tecidos de malharia circular (meiamalha, moletom, piquet e ribana) e de malharia retilínea (malhas de lã). Na malharia de urdume cada agulha do tear é alimentada por um fio colocado lado a lado para dar origem, como exemplo, aos tecidos de renda e para lingerie (ROSA, 2011).

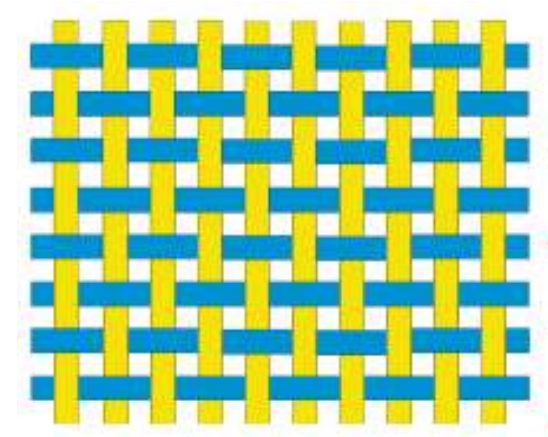

a) tecido Plano

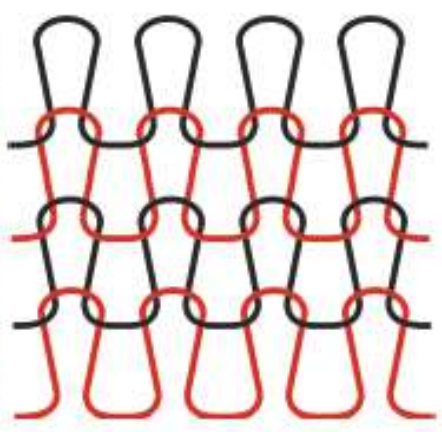

b) Tecido de Malha

Figura 4.8: Configuração das estruturas dos tecidos. Fonte: (PEREIRA, 2008, p. 34).

Não é possível utilizar os mesmos moldes para os tecidos planos e de malha. Os tecidos de malhas requerem moldes de forma e tamanho diferentes que os tecidos planos, mesmo que os desenhos do estilista sejam idênticos. Os tecidos de malha adaptam-se facilmente as partes salientes do corpo, não sendo necessária a utilização de pences ou folgas (ARAÚJO, 1996), o estiramento dos tecidos de 
malha pode compensar as variações corporais individuais que exigiriam uma modelagem mais precisa se o projeto fosse executado em um tecido plano (BRANSON; NAM, 2007). No entanto, é errado assumir que uma peça de vestuário produzida em tecido de malha irá automaticamente se adaptar aos contornos do corpo e aos seus movimentos. Por causa de sua capacidade elástica os moldes para os tecidos malha são um pouco menores que os equivalentes para tecido plano, exceto nas costuras de ombros e no comprimento (ARAÚJO, 1996).

As pences são um recurso para incorporar a profundidade aos moldes e tecidos que são bidimensionais (planos), constituídos apenas de comprimento e largura. São incluídas para controlar o volume ao longo do contorno de uma parte da peça, permitindo que ela acomode as saliências do corpo e/ou articulações. O abdômen e o peito são saliências, enquanto que um ponto de articulação é uma saliência que ocorre por causa da articulação de duas partes, tais como cotovelo, o ombro ou o joelho (ARAÚJO, 1996).

A folga (Figura 4.9) pode ser entendida como a diferença de medidas entre o utilizador e a peça de vestuário, é a distância que a roupa ficará do corpo (ARAÚJO, 1996; HEINRICH, 2007a). As medidas das peças de vestuário devem ser maiores do que as medidas do corpo do usuário, com exceção para as peças feitas de tecido elástico, tal como artigos de praia, ginástica, dança e outros. $\mathrm{O}$ tecido extra utilizado em qualquer peça de vestuário evita a restrição do corpo e seus movimentos. A quantidade de folga varia de acordo com a atividade para a qual a peça se destina, com a moda, com a estrutura do tecido, a textura, o toque e a massa. Os moldes para peças de tecido de malha não são tão folgados como os utilizados para artigo idêntico, produzido com tecido plano (ARAÚJO, 1996).

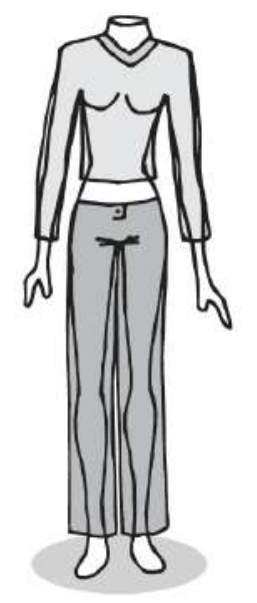

Figura 4.9: Ilustração das folgas de uma roupa. Fonte: (HEINRICH, 2007a, p. 24). 
Vale lembrar que a determinação da grade de tamanhos, a graduação, também depende do tipo de roupa e do tipo de material utilizado. Chama-se de graduação ou escala de tamanhos em modelagem o processo de aumento e diminuição de moldes, partindo-se do molde do protótipo ou da peça-piloto já aprovada. Roupas amplas não necessitam de tantos tamanhos quanto as ajustadas, e tecidos planos requerem mais tolerância do que um tecido com elastano (HEINRICH, 2007a).

\section{7.}

\section{Observações sobre o capítulo 4}

Neste capítulo foram definidos alguns termos pertinentes à moda e ao vestuário e propostas discussões acerca dos sistemas de tamanhos e medidas de artigos de vestuário. A falta de padronização dos tamanhos entre marcas e entre peças da mesma marca causa insegurança no consumidor principalmente ao comprar on-line. Este foi um tópico recorrente em todas as fases desta pesquisa e motivo pelo qual os consumidores ainda prefiram recorrer às lojas físicas em detrimento das on-line.

O capítulo seguinte irá descrever a da pesquisa exploratória. Por meio das técnicas de pesquisa selecionadas foram levantados os pontos mais relevantes para os usuários relativos à compra de roupas on-line. 


\section{Métodos e técnicas: pesquisa exploratória}

Para atingir os objetivos desta pesquisa foram utilizados métodos e técnicas divididos em: pesquisa exploratória e descritiva. A primeira fase, da pesquisa exploratória, descrita e justificada ao longo deste capítulo consistiu em: levantamento bibliográfico; revisão de literatura narrativa e sistemática; uma entrevista exploratória com uma amostra da população estudada; uma entrevista semiestruturada com especialistas de moda; um questionário on-line e o levantamento do sítio a ser usado para o estudo de caso. Uma pesquisa exploratória normalmente ocorre quando há pouco conhecimento sobre o tema a ser abordado. Por meio do estudo exploratório busca-se conhecer ou construir questões importantes para a conclusão da pesquisa (RAUPP; BEUREN, 2006). Portanto, esta forma de abordagem foi adotada para compreender como se dá a interação entre o o usuário e os sítios de e-commerce.

A segunda fase, a de pesquisa descritiva, consistiu na aplicação de um teste de usabilidade seguido de um debriefing e aplicação do questionário AttrakDiff2т ${ }^{\mathrm{TM}}$. A pesquisa descritiva define-se como um estudo intermediário entre a pesquisa exploratória e a explicativa, ou seja, não é tão preliminar quanto a primeira nem tão aprofundada quanto a segunda. Nesse contexto, descrever significa identificar, relatar comparar, entre outros aspectos. Andrade (2002) destaca que a pesquisa descritiva objetiva observar os fatos, registrá-los, analisálos, classificá-los e interpretá-los, e o sem a interferência do pesquisador. Esta etapa será pormenorizada no capítulo 6 desta dissertação.

A entrevista exploratória auxiliou na elaboração do questionário ao suscitar pontos críticos que impactam o processo decisório dos usuários ao comprar roupas on-line. Para apreender a opinião de especialistas da área foi realizada uma entrevista semiestruturada com a intenção de elucidar questões acerca do tema da pesquisa e utilizar essa informação para posteriormente elaborar um teste de usabilidade com os usuários. 
A partir das informações recolhidas nessa primeira fase da pesquisa exploratória, foi possível chegar-se aos problemas desta pesquisa. São eles:

1 Quais são as dificuldades que um usuário enfrenta ao tentar comprar uma peça de roupa?

2 Quais são as informações de um produto que necessariamente precisam ser apresentadas em um sítio para ultrapassar a barreira da falta de contato físico?

3 Até que ponto a usabilidade está sendo considerada como diretriz, levando em conta as características e singularidades dos dispositivos?

4 Como a usabilidade impacta na experiência do usuário?

\section{1.}

\section{Levantamento bibliográfico}

Em uma primeira etapa, realizou-se um levantamento bibliográfico. Este consistiu em mapear todas as referências encontradas acerca de um determinado tema, com o objetivo de compreender, analisar e avaliar as contribuições teóricas sobre o tema da pesquisa. Foi de fundamental importância para a formulação do problema de pesquisa (GIL, 2002) .

O levantamento bibliográfico dá o seu primeiro passo na escolha do tema. Marconi e Lakatos (2003) alertam que o tema não pode ser muito amplo ou inviável, uma vez determinado, deve delimitar-se o assunto. O tema desta pesquisa foi definido como: a experiência do usuário em sítios de e-commerce, com ênfase no mercado de vestuário feminino.

Com base no tema e nos problemas de pesquisa formulados, elabora-se um plano de trabalho. Trata-se de uma primeira estruturação, ideias que nortearão a leitura e a pesquisa (SEVERINO, 2000), a partir daí é possível iniciar-se a identificação das fontes capazes de fornecer a solução dos problemas propostos (GIL, 2002).

Após o levantamento do referencial teórico foi feita uma revisão da literatura. Existem três formas definidas de acordo com o método de elaboração: narrativa, sistemática e integrativa. Esta pesquisa utilizou-se dos dois primeiros tipos que serão descritos nos itens a seguir. 


\subsection{1.}

\section{Revisão narrativa da literatura}

A revisão narrativa ou assistemática, não utiliza critérios explícitos nem sistemáticos para a procura e análise da literatura. A busca não precisa esgotar as fontes, não se aplicam estratégias sofisticadas e exaustivas. É adequada para a fundamentação teórica de dissertações e teses (BIBLIOTECA DANTE MOREIRA LEITE, [S.d.]; BIBLIOTECA PROF. PAULO DE CARVALHO MATTOS, 2015).

Não foi delimitada uma data para a realização da revisão narrativa.

Para esta dissertação foram consultados: livros; artigos; artigos científicos; referências citadas por autores; periódicos; anais de congressos; sítios da internet; teses e dissertações de pessoas com conhecimento em ergonomia, usabilidade, experiência do usuário, moda e marketing.

\subsection{2.}

\section{Revisão sistemática da literatura}

A revisão sistemática é uma revisão planejada, cujo objetivo é responder a uma pergunta específica e utiliza métodos sistemáticos para identificar, selecionar e avaliar criticamente os estudos e para coletar e analisar os dados (CASTRO, 2001; PAI et al., 2004). Para esta dissertação as perguntas a serem respondidas são aquelas referentes aos problemas de pesquisa, descritas na abertura deste capítulo. Os métodos estatísticos (meta-análise), que são opcionais, não foram utilizados na análise dos resultados desta pesquisa.

Por meio do uso de palavras-chaves ao presente estudo, a busca foi realizada no sítio da biblioteca da PUC-Rio que, por sua vez, consulta as principais fontes de literatura dedicadas à pesquisa científica. Também foi feita uma busca utilizando-se as mesmas palavras-chaves no Google Scholar.

As palavras-chaves estão listadas abaixo:

comércio eletrônico; comércio eletrônico móvel; usabilidade, usabilidade móvel; usabilidade no comércio eletrônico de varejo; experiência do usuário; experiência do usuário no comércio eletrônico.

Seus correspondentes na língua inglesa: 
e-commerce; m-commerce; usability; mobile usability; user experience; ecommerce user experience; $m$-commerce e user experience.

Algumas variações das palavras-chave:

UX; ecommerce; mcommerce.

A data foi delimitada a partir de 2010, por tratar-se de um tema da área de tecnologia, artigos muito antigos podem conter informações, cuja validade não se aplica. Os artigos encontrados foram selecionados usando-se o critério de relevância com o assunto; os demais foram descartados.

\section{2.}

\section{Entrevista da pesquisa exploratória}

Uma entrevista aberta e não estruturada foi conduzida a fim de entender as percepções dos usuários ao comprar peças de vestuário em sítios de e-commerce. De acordo com Jordan, (2001), uma pesquisa não estruturada é ideal em situações em que o entrevistador tem pouca informação a priori sobre quais são os problemas ou questões que preocupam os usuários; do mesmo modo é uma maneira de explorar mais amplamente uma questão (MARCONI; LAKATOS, 1999); ou tem o objetivo de coletar dados (GIL, 2002). Entrevistas realizadas em um estágio preliminar são exploratórias por natureza e têm como objetivo colher dados do ponto de vista do usuário, perguntas amplas e abertas são comuns nestes casos (COOPER et al., 2014). A entrevista também foi realizada para servir de base para a elaboração de um questionário on-line.

As entrevistas foram realizadas utilizando o aplicativo WhatsApp, as perguntas eram feitas pela pesquisadora e imediatamente respondidas pelos entrevistados.

A entrevista foi dividida em 2 partes: as primeiras perguntas foram de cunho demográfico, informações como idade e gênero têm um enorme efeito sobre as prioridades e gostos dos consumidores (SOLOMON, 2011). A segunda parte foi formada por perguntas qualitativas.

No item a seguir, será justificada a escolha das perguntas feitas aos participantes com o intuito de levantarem-se dados e obterem-se informações acerca do tema escolhido. 


\subsection{1.}

\section{Dados demográficos}

\section{Gênero}

De acordo com o Relatório de Inteligência do Sebrae, homens representam $42 \%$ dos consumidores on-line; eles levam em média 10 minutos para finalizar uma compra on-line e $65 \%$ olham os produtos na loja física antes de adquiri-los em lojas de e-commerce. As mulheres, por sua vez, representam os outros 58\% dos consumidores on-line e demoram em média 4 minutos a mais para realizar uma compra.

Homens e mulheres têm comportamentos de consumo diferentes bem como são diferentes entre os sexos a interação com interfaces digitais. Nessa etapa da pesquisa ainda não havia sido definido qual o público seria selecionado para a realização do teste de usabilidade, por isso foram ouvidos homens e mulheres com o intuito de listar palavras e expressões que contribuíssem para identificar a relação entre o comportamento de consumo e o gênero.

2. Idade

O empresa Proxxima publicou em seu sírio um artigo sobre o estudo " $M M A$ Mobile Report 2015", realizado pela Mobile Marketing Association (PARDO, 2016). Nessa pesquisa foram entrevistadas 1.200 pessoas e foram categorizadas por faixa geracional: Millenials 14 à 24 anos; Gen Y 25 à 34 anos; Gen X 35 à 44 anos e os Boomer 45 à 55 anos. Entre os resultados, como era esperado, o grupo dos Millenials é o mais 'móvel', utilizando a rede por meio de celulares em média 4,31 horas por dia contra 3,08 dos Boomers. Assim como os hábitos de consumo on-line também são diferentes em cada faixa etária. Resultados de um estudo realizado por Sonderegger et al., 2016, revelam que o tempo levado para completar uma tarefa varia de acordo com a idade, afetando a sua eficiência. Os autores especulam que essa variação não está apenas associada à diminuição das habilidades mentais, como também a mudanças de comportamento. $\mathrm{O}$ individuo torna-se mais cauteloso e mais preocupado com acurácia da realização da tarefa do que com a velocidade para cumpri-la. É essencial ter ciência da faixa etária do usuário para possivelmente estabelecer relações dos problemas de interação humano-computador com sua idade, identificando-se o surgimento de alguma influência causada por ela. 


\section{Localização}

O $36^{\circ}$ relatório Webshoppers (E-BIT, 2017b) aponta os estados de São Paulo, Rio de Janeiro e Minas Gerais como responsáveis por $62,8 \%$ do total de compras em sítios de e-commerce no Brasil, no primeiro semestre de 2017. Outro fator que é fortemente influenciado pela região é o tíquete médio (valor total de vendas dividido pelo número total de clientes atendidos). De acordo com Bell (2016), o comportamento do consumidor on-line é diretamente influenciado pelo local onde ele vive, ou seja, o comportamento on-line é consequência das escolhas off-line.

A maior parte das compras on-line é realizada na região Sudeste do país. Obtendo-se a informação do local de origem dos respondentes, é possível equilibrar a amostra de acordo com essa proporção. Além do mais, é possível identificar diferenças nos padrões de comportamento do consumidor on-line por região, assim como na experiência do usuário e satisfação percebida.

4. Escolaridade/Atividade exercida.

O comportamento do consumidor é afetado por algumas premissas; a ocupação e as circunstâncias econômicas são dois exemplos. A escolha de um produto é extremamente afetada por suas circunstâncias econômicas: renda disponível, economias e bens, débitos e capacidade de endividamento e atitude em relação a gastar versus economizar (KOTLER, 2000). Portanto, as atividades/escolaridade podem estar relacionadas com o modo como o usuário interage com interfaces digitais, bem como com os seus hábitos de consumo. Pessoas com um nível maior de escolaridade, tendem a ter um padrão econômico mais elevado. Estudos macroeconômicos e, mesmo, do mercado consumidor demonstram que: universitários formados ganham cerca de $50 \%$ mais do que as pessoas que só cursaram o ensino médio. As mulheres sem diploma do ensino médio ganham apenas $40 \%$ do que recebem as que concluíram o ensino superior (SOLOMON, 2011).

\section{Frequência de compras on-line}

A confiança nos sistemas de compra pela internet vem aumentando consideravelmente. Sistemas criptografados contribuem para a segurança dos sites e incentivam as compras. A usabilidade tem papel importante pois será um definidor na navegação e nas conclusões de compra. De acordo com Jordan, (2001) a experiência prévia com um produto provavelmente irá afetar o quão fácil 
ou difícil será para completar uma tarefa. As compras pela internet dependem da objetividade do comprador, conhecer o usuário e seus hábitos também contribui para o design de páginas com um maior grau de usabilidade (HANSEN apud SANTA ROSA; MORAES, 2012 ).

As perguntas descritas nos itens anteriores tiveram o intuito de identificar a frequência de compra do público usuário de e-commerce, perfilar a amostra a ser estudada e, consequentemente, criar grupos equilibrados de participantes que têm mais ou menos experiência de compra on-line e compreender os impactos na usabilidade, os participantes foram questionados .

\subsection{2.}

\section{Perguntas qualitativas}

1. Nível da experiência do usuário

A imagem que o usuário faz da interface influencia o seu comportamento assim como sua experiência anterior de programas que já utilizou, além de fatores culturais. Uma interface digital pode considerar quatro modelos mentais genéricos:

1) O modo através do qual os usuários percebem a interface;

2) O modo através do qual os projetistas percebem a interface e sua relação com o usuário;

3) O que a interface efetivamente mostra ao usuário, de modo que possa usá-la intuitivamente;

4) O modelo conceitual (ou psicológico) que o usuário elabora a partir do que vê.

(CARROLL; OLSON, 1987; JORDAN, 2001; NIELSEN, 1993, 2009).

A experiência de compra on-line é dependente do background do comprador assim como do grau de usabilidade e confiabilidade do site.

Os entrevistados foram solicitados a descrever a sua última experiência de compra on-line, a fim de compreender e listar os problemas e obstáculos percebidos por consumidores ao comprarem on-line e poder listar pontos positivos, negativos e interessantes (PNI) e identificar características do modelo mental do compradores de vestuário on-line. 
2. Confiança

O Relatório de Inteligência Sebrae aponta que 56\% (SEBRAE-RJ, 2014) das pessoas não compram on-line por medo de não receber o que foi comprado. McKnight e Choudhury (2006) argumentam que comprar on-line envolve ao menos três perigos: o de não receber a mercadoria adquirida; ser vítima de fraude; e, aumento de risco percebido por não ter contato direto com o produto. Ter de compartilhar informações, como o número de cartão de crédito, também contribuem para a falta de confiança para realizar compras on-line. Sítios devem ser confiáveis e ter uma apresentação que transmita credibilidade aos usuários; devem ter um design de qualidade, transparência nas informações; fornecer informações atuais e corretas; e devem estar conectados com o restante da web (BEDFORD, 2016). Portanto, sítios com baixa usabilidade afastam os clientes e podem proporcionar uma experiência do usuário negativa. As variáveis que mais impactam nas atividades de compras são a usabilidade e a segurança do sistema.

Com base em um dos pressupostos desta pesquisa - "as informações fornecidas sobre o produto são insuficientes ou superficiais dificultando a tomada de decisão do consumidor" - os usuários foram solicitados a responder a seguinte pergunta: "O que um sitio de compras precisa ter para lhe transmitir alguma confiança para a realização de compras?”. A boa usabilidade está diretamente ligada ao conhecimento do seu usuário e como ele interage com uma interface digital (LEVY, 2015). Ao identificar os pontos positivos que contribuem para que ele concretize a compra e retorne, futuramente, à mesma loja, é possível conhecêlo melhor e seus modelos mentais e assim contribuir para o projeto de sítios com um maior nível de usabilidade e para uma experiência do usuário positiva.

\subsection{3.}

\section{Análise dos resultados da entrevista exploratória}

Essa série de entrevistas com cunho exploratório, foi realizada com o intuito de elaborar posteriormente um questionário on-line. A seguir serão apresentados os resultados organizados por tópicos:

a) Perfil dos entrevistados: gênero, idade e escolaridade 
Foram entrevistadas 19 pessoas, estavam parcialmente divididos por gênero, com homens e mulheres de 23 a 77 anos (Figura 5.1). A maioria com ensino superior completo (Figura 5.2).

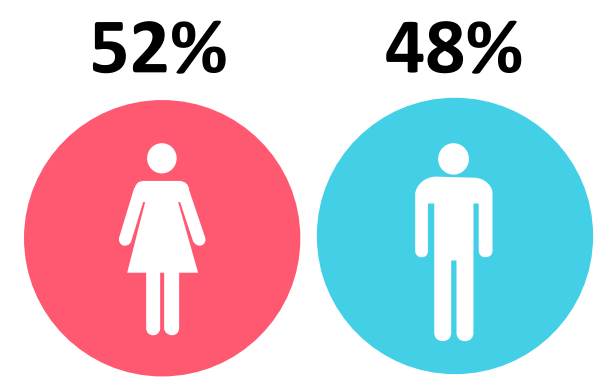

\section{3-77 anos}

Figura 5.1 - Idade e gênero dos entrevistados. Fonte: elaborado pela autora

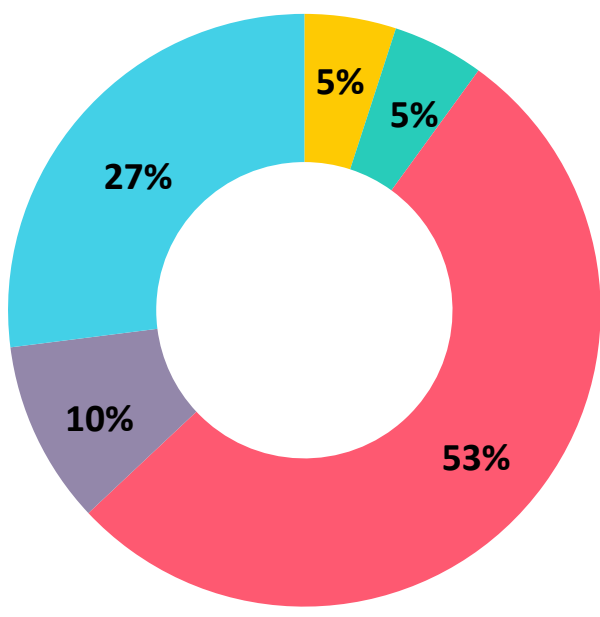

Segundo grau completo

Superior incompleto

Superior completo

Pós-graduação incompleta

Pós-graduação completa

Figura 5.2 - Escolaridade dos entrevistados. Fonte: elaborado pela autora.

b) Frequência de compras on-line

Dos entrevistados, $42 \%$ declararam comprar on-line 2 vezes ao mês, $26 \%$ a cada 2 meses, $16 \%$ a cada 3 meses, 11\% não fazem compras on-line e 5\% fazem compras on-line semanalmente (Figura 5.3). 


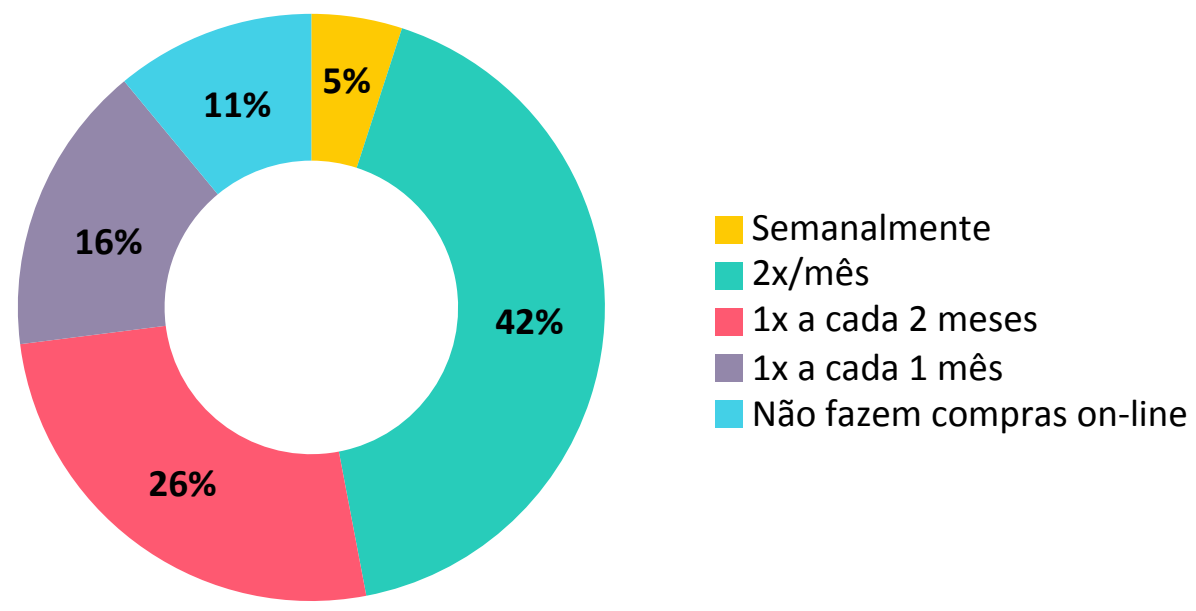

Figura 5.3 - Frequência de compras on-line dos entrevistados. Fonte: elaborado pela autora.

c) Distribuição geográfica dos respondentes

A grande maioria dos respondentes (79\%) são da região Sudeste do país, $11 \%$ da região Nordeste e 10\% residem nos Estados Unidos (Figura 5.4).

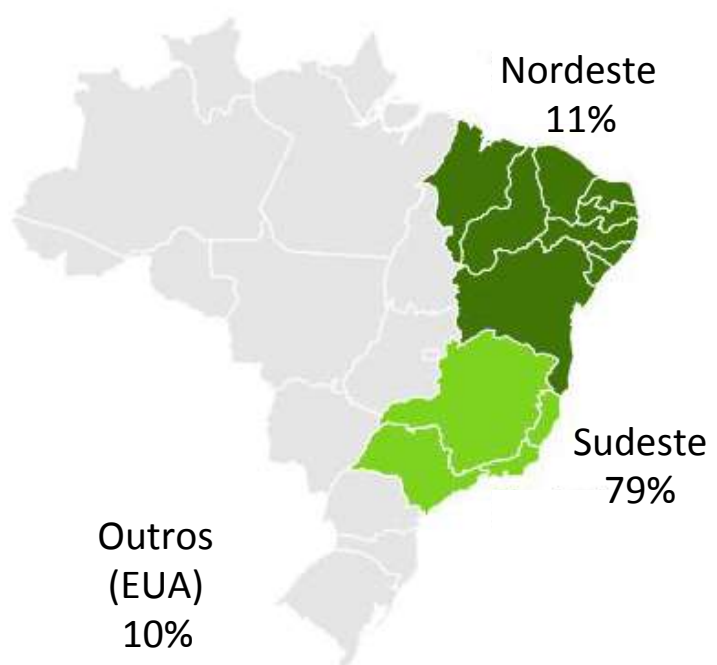

Figura 5.4 - Distribuição dos entrevistados. Fonte: elaborado pela autora.

As respostas às duas perguntas de cunho qualitativo ("Relate sua experiência ao comprar on-line" e "O que um sítio de compras precisa ter para lhe transmitir alguma confiança para a realização de compras?”) foram agrupadas em 3 itens: Confiança, Preço e Entrega. 3 fatores cujo o impacto é determinante para proporcionar uma boa experiência ao usuário. Abaixo estão destacadas as principais respostas: 


\section{1) Confiança}

Apesar dos números indicarem um alto número de consumidores que efetuam compras on-line, 25,5 milhões de consumidores ativos somente no primeiro semestre de 2017 (E-BIT, 2017b), ainda há quem não confie no ambiente digital “...não acho confiável essas compras.” A falta de informações claras, também resulta em uma baixo nível de confiança (BEDFORD, 2016), "Eu não sabia que podia arrepender e devolver. Mas, se tratando de Brasil, não confio. Acho que seria um parto para devolver e ter o reembolso integral..." (sobre a Lei de Arrependimento - Lei 8078/9099).

Para Cybis et. al. (2010) uma barreira é um problema de usabilidade em que o usuário esbarra sucessivas vezes e não aprende a suplantá-la sem ajuda externa. A disparidade nas medidas das roupas brasileiras é uma barreira para alguns usuários na hora de comprar peças de vestuário em sítios de e-commerce. Um dos entrevistados declarou comprar roupas em sítios internacionais e solicitar a entrega na casa de parentes que residem no exterior para burlar a inconsistência nos tamanhos de roupas brasileiras. "Compro em sites brasileiros, tipo Oppa, wine.com, Saraiva, Pão de Açúcar mas não roupa. Aqui (no Brasil) os tamanhos variam muito. Já na Zara e Gap (o tamanho) é padronizado e não tem erro”. A inconsistência nos tamanhos e a distância entre o digital e o físico foram mencionadas em outras respostas: "O que não compro é roupa pessoal para mim. Por não ter um corpo fácil e padrão fico insegura se vai ficar bom ou não". "Já comprei várias outras coisas, mas roupas eu não gosto. Porque só compro depois de experimentar".

Os entrevistados que moram nos Estados Unidos mencionaram as excelentes políticas de troca. Receber um produto que não caiba ou não esteja de

\footnotetext{
${ }^{9}$ CDC - Lei n ${ }^{\circ} 8.078$ de 11 de Setembro de 1990_Dispõe sobre a proteção do consumidor e dá outras providências.
}

Art. 49. O consumidor pode desistir do contrato, no prazo de 7 dias a contar de sua assinatura ou do ato de recebimento do produto ou serviço, sempre que a contratação de fornecimento de produtos e serviços ocorrer fora do estabelecimento comercial, especialmente por telefone ou a domicílio.

Parágrafo único. Se o consumidor exercitar o direito de arrependimento previsto neste artigo, os valores eventualmente pagos, a qualquer título, durante o prazo de reflexão, serão devolvidos, de imediato, monetariamente atualizados. 
acordo com as fotos nos sítios não é uma barreira para a compra pois a troca é facilitada e garantida.

2) Preço

Quanto maior for o preço do produto mais o conteúdo de um sítio precisa despertar a confiança do usuário (KIM; BENBASAT, 2009), sendo então a prática de preços menores um contraponto para a confiança em ambientes digitais. "As vezes, mesmo pagando frete, sai mais barato que comprar nas multimarcas aqui em São Luís”. “...eu experimento um óculos de sol na loja e procuro por um preço melhor ." "Comprei uma bolsa de marca por um terço do preço”. "Apesar de estar morando numa capital agora, continuamos com esse hábito, seja por questão de preço ou por falta de lojas fisicas das marcas que consumimos, como a Farm, Nespresso, etc."

3) Entrega

Outro dado interessante, levantado durante a pesquisa exploratória, foram as barreiras para a entrega do produto. Alguns indivíduos não compram on-line por não terem quem receba a encomenda, ou por morarem em áreas consideradas de risco, onde os Correios não atuam. Em algumas cidades do interior, os Correios não fazem entregas todos os dias e, portanto, torna-se um impedimento para a compra em sítios de e-commerce, tornando a ida à uma loja física mais conveniente. "É que o pessoal prefere comprar nas lojas mesmo. Porque os donos compram em Fortaleza. E aqui não tem correio todo dia por isso o pessoal não compra". Por outro lado, o fato de alguns usuários de e-commerce residirem em lugares mais remotos, os faz mais tolerantes à demora no recebimento do produto. Esta situação não é percebida como um obstáculo para a compra.. "Tive um pacote devolvido. Comprei mais duas (calças) para receber as 4 juntas".

Pode concluir-se com base nas verbalizações dos entrevistados que a confiança é a principal barreira enfrentada pelos consumidores, principalmente no que se refere a sítios de e-commerce de vestuário. Este é um fator subjetivo na interação do usuário com o sítio e nos remete às qualidades hedônicas de um produto, descritas no capítulo 2. A falta de confiança, nos caso relatados nos itens anteriores, está ligada à ausência de informações suficientes sobre os produtos que, em alguns casos, impede o cumprimento da tarefa e proporciona uma experiência do usuário negativa. 
Existe uma disparidade nas medidas do vestuário brasileiro, (capítulo 3), e por causa da impossibilidade de experimentar a peça para verificar o caimento e o tamanho, os consumidores ficam temerosos quanto à sua satisfação em relação ao produto recebido.

Contudo, estudos mostram que os usuários demonstram-se dispostos a transpor esse problema para a aquisição de produtos com um baixo valor monetário (KIM; BENBASAT, 2009), essa questão deve ser considerada posteriormente.

\section{3. \\ Questionário ${ }^{10}$ on-line}

Um questionário é um instrumento de coleta de dados constituído por uma série ordenada de perguntas, que devem ser respondidas por escrito e sem a presença do entrevistador. É vantajoso por economizar tempo, atingir um número grande de pessoas, abranger uma área geográfica mais ampla, obter respostas rápidas e precisas e dar mais liberdade para os respondentes em razão do anonimato (MARCONI; LAKATOS, 1999).

Com o intuito de recrutar participantes para um teste de usabilidade a ser realizado posteriormente, foi elaborado um questionário on-line. A ferramenta utilizada foi Google Formulários, software desenvolvido pela Google especialmente para a criação de formulários e questionários. $\mathrm{O}$ questionário continha perguntas qualitativas com a finalidade de adquirir mais informações de como os usuários interagem com interfaces de sítios de e-commerce de vestuário. Os critérios para a elaboração das perguntas de perfil foram os mesmos utilizados na entrevista exploratória, explicitados nos itens 5.2.1. e 5.2.2. deste capítulo. As demais perguntas foram baseadas nos questionamentos e dúvidas dos entrevistados.

É essencial testar o questionário antes de enviá-lo a um grande número de pessoas (CYBIS; HOLTZ; FAUST, 2010). Segundo Gil, (2002), um pré-teste deve ser enviado para 10 a 20 indivíduos pertencentes ao grupo avaliado. Além de realizar um pré-teste, é igualmente importante fazê-lo utilizando os mesmos meios do questionário real. Em outras palavras, se for um questionário por meio

${ }^{10} \mathrm{O}$ questionário está disponível em: https://goo.gl/forms/wKqHbwGizdhMcZc02 
telefônico, deverá ser feito por telefone, se for utilizar uma ferramenta on-line, deverá utilizar a mesma ferramenta para o teste e assim por diante (RUBIN; CHISNELL, 2008). Verificadas as falhas, deve-se reformular o questionário, fazendo as alterações necessárias (MARCONI; LAKATOS, 1999).

O primeiro questionário piloto foi enviado no dia 23/03/16 para 12 pessoas (5 homens e 7 mulheres) e encerrado no dia 04/04/2016. A ferramenta utilizada foi o GoogleForms, software desenvolvido pela Google especialmente para a criação de formulários e questionários. 10 pessoas responderam. O questionário consistia de perguntas divididas em 8 seções:

1. Apresentação;

2. Informações pessoais;

3. Compras on-line;

4. Pessoas que não compram on-line;

5. Pessoas que não compram roupas on-line;

6. Pessoas que não usam o celular para comprar on-line;

7. Disponibilidade; e

8. Comentários.

Algumas modificações foram necessárias para melhorar o grau de entendimento de certos itens. Um dos respondentes não entendeu os objetivos da seção "Disponibilidade", portanto, incluiu-se um texto introdutório esclarecendo sua finalidade. O texto de apresentação foi encurtado, em decorrência de alguns comentários referindo-se ao seu conteúdo demasiadamente longo. A pergunta: "Houve algum problema ou obstáculo durante o processo de escolha e compra de produto(s)?" foi substituída por: "Relate sua experiência durante o processo de escolha e compra de produto(s)?”. Deve evitar-se sugerir respostas (MUCCHIELLI, 1979), a reformulação da questão a tornou mais neutra evitando que fosse tendenciosa, induzindo o respondente a relatar problemas ou obstáculos e não lhe oferecendo a oportunidade de citar experiências positivas em processos de compras on-line.

Foram incluídas as seguintes questões: “Qual celular possui?” e "Há quanto tempo é usuário de internet móvel?”. Além disso, A solicitação do e-mail foi transferida para a seção de comentários e o "Termo de Consentimento e Livre Esclarecimento" foi incluído na introdução. Em razão da inclusão dessas novas 
perguntas foi realizado um segundo pré-teste, enviado no dia 9/4/16 para mais 5 pessoas.

O questionário definitivo foi disponibilizado no dia 4/05/16. Na seção de perguntas de cunho demográfico foi incluída uma questão acerca da ocupação dos respondentes. Em consequência do mal entendimento de um dos respondentes do segundo piloto, a pergunta “Qual celular possui?” foi alterada para: “Qual modelo e marca de celular possui?"”. O questionário foi encerrado no dia $02 / 07 / 2016$, ao atingir a marca de 205 respondentes seguindo a distribuição por região do Brasil de acordo com os dados dos seguintes relatórios de e-commerce: ComScore, Conversion, $32^{\circ}$ Webshoppers e $33^{\circ}$ Webshoppers (Tabela 5.1).

\begin{tabular}{lcccc}
\hline & Com Score & Conversion & 32\% Webshoppers & Nossa distribuição \\
\hline Centro oeste & $8,30 \%$ & $6,17 \%$ & $6,10 \%$ & $7,50 \%$ \\
Nordeste & $17,50 \%$ & $9,26 \%$ & $12,90 \%$ & $9,00 \%$ \\
Norte & $3,70 \%$ & $4,02 \%$ & $2,80 \%$ & $5,50 \%$ \\
Sudeste & $50,70 \%$ & $69,44 \%$ & $64,50 \%$ & $59,00 \%$ \\
Sul & $19,80 \%$ & $11,07 \%$ & $13,70 \%$ & $15,00 \%$ \\
Outros & & & & $4,00 \%$
\end{tabular}

Tabela 5.1 - Distribuição de volume de compras por região no Brasil. Fonte: Elaborado pela autora.

\subsection{1.}

\section{Estrutura do questionário on-line}

O questionário on-line iniciava-se com uma apresentação explicando os seus objetivos e com o Termo de Consentimento e Livre Esclarecimento. As perguntas foram separadas em 7 seções:

1. Informações pessoais - Os participantes eram solicitados a informar: o sexo; grau de escolaridade; ocupação e local de moradia;

2. Compras on-line - Nesta seção os participantes eram solicitados a responder perguntas sobre seu comportamento de compras utilizando a internet; se já haviam feito compras on-line; os motivos que o levou a comprar on-line; quais os tipos de produtos que tinham hábito de comprar; se já haviam comprado roupas on-line; como havia sido sua última experiência de compra on-line; os 3 sítios onde costumavam efetuar compras; o modelo e a marca do celular; há quanto tempo eram usuários de internet móvel e se já haviam realizado compras utilizando um smartphone; 
3. Pessoas que não compram on-line - As pessoas que respondiam negativamente a pergunta: "Você já fez compras on-line?" eram encaminhas para esta seção. Elas eram solicitadas a responder por que não compravam online;

4. Pessoas que não compram roupas on-line - As pessoas que respondiam negativamente a pergunta: "Você já comprou roupas on-line?" eram solicitadas a escolher uma das opções do por quê de não comprarem on-line;

5. Pessoas que não usam o celular para comprar on-line - As pessoas que respondiam negativamente a pergunta: "Você já utilizou ou utiliza um telefone celular para comprar online?" eram solicitadas a eram solicitadas a escolher uma das opções do por quê de não comprarem on-line;

6. Disponibilidade - Os participantes eram solicitados a fornecer dados sobre sua disponibilidade para participar de um posterior teste de usabilidade; os dias e horários e um e-mail para contato; e

7. Comentários - Nesta seção os participantes podiam deixar comentários sobre o questionário.

\subsection{2.}

\section{Resultados do questionário on-line}

\section{Perfil da amostra de respondentes}

O questionário teve por objetivo compreender mais profundamente o comportamento do usuário quanto à compra on-line. Por isso, a amostra foi aleatória, sem um perfil específico pré-determinado.

A maioria dos respondentes foi mulher (68,5\%), 205 pessoas responderam o questionário, com idades entre 18 e 69 anos (Figura 5.5). Do total de respondentes $48 \%$ possuíam pós-graduação completa, na Figura 5.6 é possível conferir os demais níveis de escolaridade. 


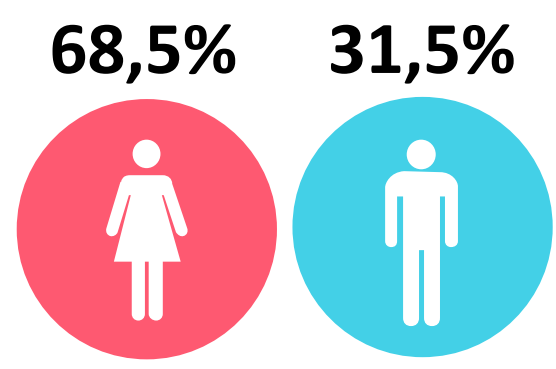

\section{8-69 anos}

Figura 5.5 - Idade e gênero dos participantes do questionário. Fonte: elaborado pela autora. $2,5 \%$

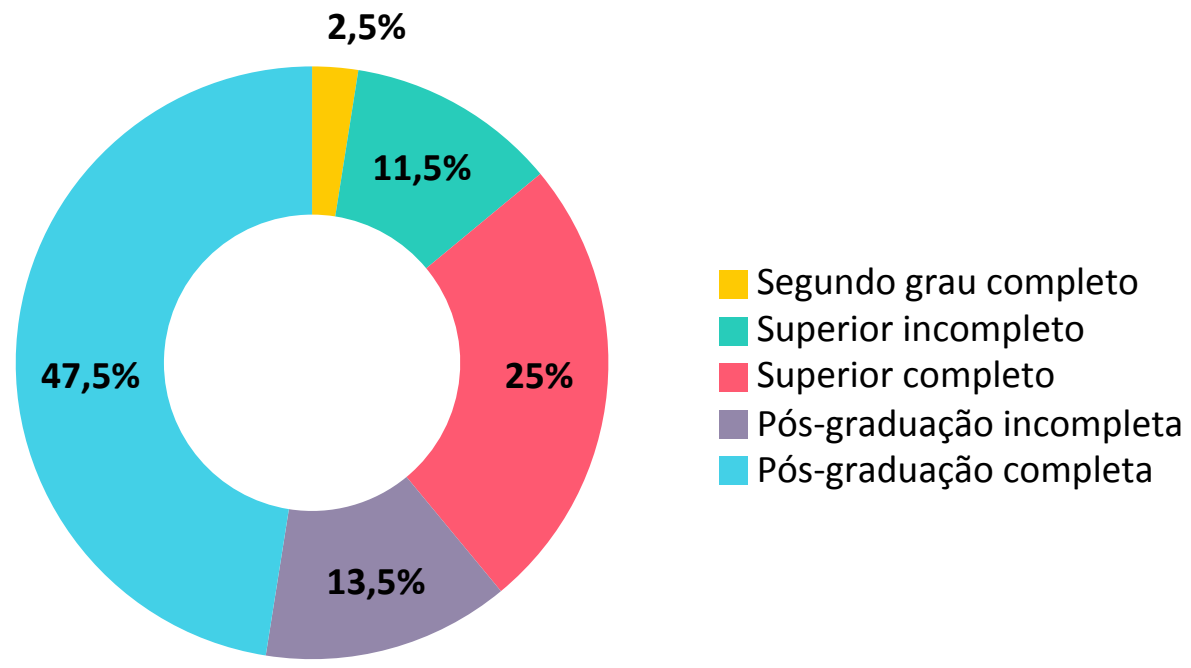

Figura 5.6 - Escolaridade dos participantes do questionário. Fonte: elaborado pela autora.

Dos entrevistados, 99,5\% \% declararam já terem comprado on-line, $(51 \%$ mulheres e $49 \%$ homens), e $0,5 \%$ nunca comprou on-line.

\begin{tabular}{lll} 
Compro on-line porque... & Brasil & $\%$ \\
\hline É prático & 165 & $83 \%$ \\
É fácil comparar preços & 150 & $75 \%$ \\
É mais barato & 104 & $52 \%$ \\
Não preciso ir até a loja & 95 & $48 \%$ \\
Por causa da facilidade de entrega & 59 & $30 \%$ \\
Não tenho acesso à muitas lojas & 13 & $7 \%$ \\
Outros & 9 & $5 \%$ \\
É mais seguro do que ir à loja & 6 & $3 \%$ \\
\hline
\end{tabular}

Tabela 5.2 - Razões para comprar on-line. Fonte: Elaborado pela autora. 
Em relação ao motivo para as pessoas comprarem on-line, destaca-se a praticidade e a facilidade de comparar preços, $83 \%$ e $75 \%$, respectivamente, $52 \%$ compram por causa dos preços mais baixos (Tabela 5.2).

Diferente do Webshoppers (E-BIT, 2017b), a categoria mais comprada pelos respondentes do questionário é a de livros/assinaturas e revistas, com 66\%, a categoria de moda e acessórios apareceu em $3^{\circ}$ lugar com $52 \%$.

Mais da metade dos respondentes (65\%) declararam já terem comprado roupas on-line e $75 \%$ já efetuaram compras on-line utilizando um telefone celular.

Dos $45 \%$ que não compram roupas on-line os principais motivos que os impedem de comprar são: não saber se a roupa vai caber $(81 \%)$ e insegurança quanto ao caimento (87\%). Na tabela 5.3 é possível verificar todos os motivos e seus resultados.

\begin{tabular}{ll} 
Não compro roupas on-line porque... & Brasil \\
Insegurança quanto ao caimento da roupa & $87 \%$ \\
Não sei se a roupa vai caber em mim & $81 \%$ \\
Insegurança quanto ao material de que é feito a roupa & $61 \%$ \\
Dificuldade para trocar caso a roupa não caiba em mim & $51 \%$ \\
Acho mais fácil ir até a loja & $43 \%$ \\
Não há informações suficientes sobre o produto & $12 \%$ \\
As informações expostas são confusas & $10 \%$ \\
Nunca encontro o que eu quero & $1 \%$ \\
\hline
\end{tabular}

Tabela 5.3 - Razões para não comprar roupas on-line. Fonte: Elaborado pela autora.

\section{4 .}

\section{Entrevista com especialistas}

Com a intenção de obter a visão de especialistas da área de moda acerca das questões abordadas nessa pesquisa foram realizadas entrevistas semiestruturadas com 6 profissionais de modelagem. Uma entrevista tem como principal objetivo a obtenção de informações do entrevistado, sobre determinado assunto ou problema (MARCONI; LAKATOS, 1999).

Os especialistas possuíam os seguintes perfis profissionais (aqui resumidos):

E1 - Doutor em Design, PUC-Rio e professor de diversas disciplinas de moda.

E2 - Pós graduação em Tecnologia da Modelagem, FIT/NY. Professor de Modelagem Tridimensional e Ergonomia do Vestuário. 
E3 - Especialista em Moda, Cultura de Moda e Arte; tecnólogo em Produção do Vestuário, Professor de modelagem.

E4 - Estilista, figurinista, professor, com formação em Moda pelo Surrey Institute of Art and Design, Londres.

E5 - Especializado em Design de Moda (lato sensu), e graduado em Design de Moda.

E6 - Graduado em Desenho Industrial com habilitação em moda; graduado em Tecnologia em Produção de Vestuário pelo Senai-CETIQT.

As entrevistas foram realizadas entre os dias 7 de abril e 24 de maio de 2016, gravadas utilizando um smartphone e posteriormente transcritas e analisadas, utilizando-se do método Análise de Conteúdo.

\subsection{1.}

\section{Análise de conteúdo da entrevista com especialistas}

Segundo Bardin (2011), a análise de conteúdo é um conjunto de instrumentos metodológicos que se aplicam a "discursos" extremamente diversificados. Para Weber (1990), é um método de pesquisa que utiliza um conjunto de procedimentos para fazer inferências válidas sobre um texto. Seu objetivo é compreender criticamente o sentido das comunicações, seu conteúdo explicito ou latente (CHIZZOTTI, 2000).

A decodificação de um documento pode utilizar-se de diversos procedimentos, sua escolha depende do material a ser analisado e dos objetivos do pesquisador (CHIZZOTTI, 2000). As diferentes fases da análise de conteúdo organizam-se em três etapas: a pré-análise, a exploração do material e o tratamento dos resultados, a inferência e a interpretação (BARDIN, 2011).

1) Pré-análise - É a fase de organização propriamente dita. Geralmente, esta primeira fase possui três objetivos: a escolha dos documentos a serem submetidos à análise, a formulação das hipóteses e dos objetivos e a elaboração de indicadores que fundamentem a interpretação final;

2) A exploração do material - Esta fase consiste em operações de codificação, decomposição ou enumeração, em função de regras previamente formuladas; e 
3) Tratamento dos resultados obtidos e interpretação - Nesta terceira e última fase os resultados são tratados de modo a serem significativos. São utilizadas operações estatísticas simples ou mais complexas. São estabelecidos quadros de resultados e demais formas de apresentação de resultados.

Após a leitura exaustiva das transcrições, ordena-se e classifica-se o seu conteúdo, considerando-se os objetivos do estudo e as questões teóricas apontadas. O produto deste processo é a emersão de temas que ao serem submetidos a uma análise cuidadosa resultam um elenco final.

Como apoio para melhor entendimento da técnica foram usados os seguintes trabalhos: (MIRANDA, 2004) e (BEZERRA, 2009).

\subsection{2.}

\section{Execução da análise de conteúdo}

Como descrito no item anterior, a análise de conteúdo possui três fases apresentadas a seguir:

$\underline{1 .}$ A Pré-Análise

Nesta etapa organizou-se o material a ser analisado com o objetivo de tornálo operacional e sistematizar as ideias iniciais. Foram feitas as transcrições das entrevistas e, em seguida, uma leitura minuciosa do material produzido.

O segundo passo foi selecionar o material a ser analisado, formando-se o corpus de análise. A partir da leitura das transcrições, listou-se o referencial de codificação. Cada especialista recebeu uma identificação (E1 à E6). Foram consideradas somente as verbalizações relevantes aos objetivos deste estudo, as demais foram desconsideradas. Compilou-se as verbalizações selecionadas em um novo documento nomeado: "Análise entrevista com especialistas".

\section{A Exploração do Material}

Todas as informações relevantes para esta pesquisa originaram as unidades de registro do referencial de codificação. As unidades de registro são as unidades de significação codificadas e correspondem ao segmento de conteúdo considerado como base. A unidade de contexto, por sua vez, serve de unidade de compreensão para codificar a unidade de registro. 
As informações contidas nas transcrições foram agrupadas em 9 unidades de contexto e suas respectivas unidades de registro, listadas abaixo. Vale, ressaltar que os títulos de cada unidade foram determinados pela autora.

- $\quad$ Padronização:

○ Referências base para a construção do vestuário;

○ O que é padronização?;

○ Impossibilidade de padronização devido a grande diversidade de corpos;

○ Diversidade nos tamanhos;

- Respeito a individualidade de cada marca;

○ Normatização;

○ Demanda do consumidor por uma padronização;

○ Necessidade de padronização;

○ Padronização fundamental para comercialização e manutenção das marcas no mercado;

○ Padronização;

○ Possiblidade de padronização;

- Desnecessário um padrão; e

○ Revisão da qualificação dos profissionais de modelagem

- Informação:

- Conhecer o público / Conhecer melhor o consumidor;

- Feedback constante dos consumidores;

- Informação e transparência para o consumidor;

- Falta de conhecimento do cliente para se medir;

- Pesquisas na área; $\mathrm{e}$

- Colocar em prática a pesquisa.

- Indústria:

○ Impacto na indústria;

○ Produção em massa;

- Retorno para a marca;

- Aumento da rentabilidade;

○ Economia de material;

- Benefício para a indústria;

○ Diminuição do número de devoluções;

○ Ineficiência da modelagem dificultando a exportação; e 
○ Atraso do Brasil em relação ao desenvolvimento do mercado.

- $\quad$ On-line e off-line:

○ Compra de peças maiores para não errar;

- Tecnologia para diminuir a barreira;

- Tecnologia ajudando a moda;

○ Caimento da roupa, além da modelagem;

○ Diminuição do medo de comprar online;

- Aumento de lojas online por causa do custo da loja física;

○ Problemas com devolução e troca; e

- Diversidade nos tamanhos e a impossibilidade de experimentar.

- $\quad$ Diversidade brasileira:

- Diversidade dos corpos das brasileiras;

- Mudança do corpo do brasileiro;

- Tabelas mais atuais para acompanhar mudança nos corpos dos brasileiros; e

○ Tabela para interferências estéticas.

- $\quad$ Grau de acerto:

- Melhora do grau de assertividade; e

- Melhora do grau de assertividade usando moulage.

- Confiança:

- Aumentar a confiança do consumidor;

- Confiança no produto que está comprando;

- Satisfação do usuário/consumidor;

- Apoio ao consumidor para ele se sentir mais seguro, mesmo que seja online.

- $\quad$ Fator psicológico das medidas:

○ Influência do fator psicológico das medidas.

- $\quad$ Estudo SENAI Cetiqt.

○ Complexidade do estudo; e

○ Não conhecia o estudo.

Com isso foi determinada a frequência em que cada especialista citou as unidade de registro para cada unidade de contexto. 


\section{O Tratamento dos Resultados Obtidos e Interpretação}

Nesta terceira e última etapa foi elaborada uma tabela com as unidades de contexto e as unidades de registro e a frequência com que cada especialista citou cada uma das unidades de registro e a frequência total por unidade de contexto (Tabela 5.4). Desta forma, conseguiu-se um tratamento estatístico simples para a interpretação das verbalizações dos especialistas durante a entrevista (Apêndice 2).

Também foi gerada uma nuvem de palavras (Figura 5.7) com o intuito de obter-se uma visualização gráfica da frequência dos termos mais usados pelos especialistas. Para isso foi utilizado o aplicativo on-line Wordle (wordle.com). Para a geração da nuvem o documento com a extração das verbalizações mais relevantes foi utilizado, mas antes foram eliminadas todas as palavras comuns e somente utilizada as palavras-chaves, referentes ao estudo. Também foram agrupadas as palavras no plural com as no singular, assim como as palavras com significados muito próximos.

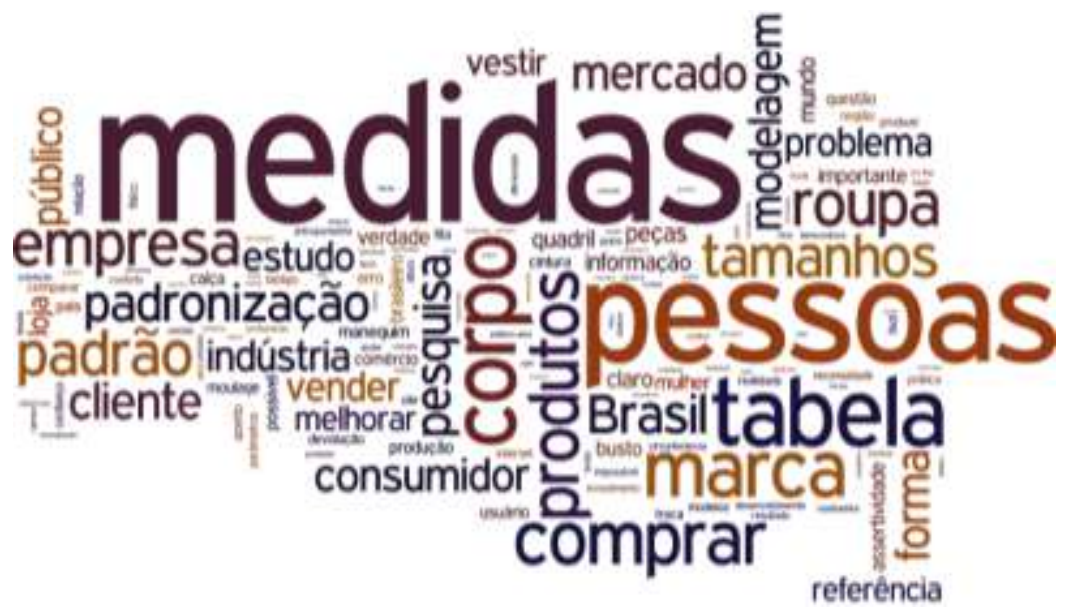

Figura 5.7 - Nuvem com frequência de palavras-chaves ditas pelos especialistas de moda nas entrevistas. Fonte: Elaborado pela autora.

\begin{tabular}{lcc}
\hline \multicolumn{1}{c}{ Unidade de contexto } & $\begin{array}{c}\text { Total de } \\
\text { ocorrências }\end{array}$ & $\begin{array}{c}\text { \% sobre o } \\
\text { total de }\end{array}$ \\
\hline Padronização & $\mathbf{4 1}$ & $25,79 \%$ \\
\hline Informação & $\mathbf{4 2}$ & $26,42 \%$ \\
\hline Indústria & $\mathbf{1 8}$ & $11,32 \%$ \\
\hline Online e offline & $\mathbf{1 1}$ & $6,92 \%$ \\
\hline Diversidade brasileira & $\mathbf{1 2}$ & $7,55 \%$ \\
\hline Grau de acerto & $\mathbf{1 3}$ & $8,18 \%$ \\
Confiança & $\mathbf{8}$ & $5,03 \%$ \\
Fator psicológico das medidas & $\mathbf{1 0}$ & $6,29 \%$ \\
\hline Estudo SENAI Cetiqt & $\mathbf{4}$ & $2,52 \%$ \\
\hline Total & 159 & $100 \%$ \\
\hline
\end{tabular}

Tabela 5.4 - Frequência das unidades de contexto nas entrevistas com os especialistas. Fonte: Elaborado pela autora. 


\section{5.}

\section{Resultados da entrevista com os especialistas}

Dentre as unidades de contexto mais mencionadas nas entrevistas com os especialistas estão "Padronização" e "Informação". Somadas são mais do que $50 \%$ do total de ocorrências registradas por meio da Análise de Conteúdo, das 6 demais unidades de contexto somente "Indústria" obteve mais do que $10 \%$ das ocorrências. Isto posto, somente as duas unidades de contexto de mais destaque serão pormenorizadas a seguir.

A unidade de contexto "Padronização" resultou em 13 unidades de registro, destacando-se duas: "Referências para a construção do vestuário" e "Necessidade de padronização". A primeira unidade está relacionada às diferentes referências nas quais as modelagens brasileiras foram baseadas. Nesse ponto houve quase consenso, segundo os especialistas, como os estudos antropométricos demoraram a serem desenvolvidos no Brasil, buscou-se diversas fontes estrangeiras resultando em inúmeras tabelas com diferentes medidas e sem considerar as especificidades dos corpos dos brasileiros. "Se você for ao mercado hoje buscar bibliografia de modelagem traduzida para o português você vai encontrar uma infinidade de livros em que já apresentação no material não é padronizada, tem diferenciais na apresentação dos nomes das medidas, na forma como se mede". "Das medidas, a gente aqui no Brasil, não tinha referencial, então o pessoal buscou referencial em vários lugares diferentes e acabou despadronizando mesmo isso".

A segunda unidade de registro, "Necessidade de padronização" revelou algumas opiniões bastante distintas entre os especialistas, alguns defendem a padronização das tabelas de medidas para que as marcas sigam a mesma numeração "Hoje a gente se depara com a parte do e-commerce, que sem a padronização não tem como comercializar e fidelizar, os clientes, na compra dos produtos pela internet”, “...na minha opinião, é totalmente possível, padronizar”.

Outros, não acham necessário um padrão de medidas “...hoje eu não acredito que seja mais necessário esse padrão”. E que cada marca deva criar a sua tabela de medidas "Eu acho muito legal cada marca criar o seu, a sua tabela, seus padrões que você segue ali assim, claro, ela só vai fazer isso observando o 
público dela”. E ainda há os que acreditam que padronizar não seja possível "Então eu acho que pensar numa, possibilidade de padronização que vá atender a todos esses corpos femininos do nosso país, eu acho que é impossível. Mas o que a gente tem que levar em conta, é tentar uma, uma possibilidade de tentar padronizar o mínimo possivel”.

A unidade de contexto "Informação" gerou 6 unidades de registro, destacando-se "Informação e transparência para o consumidor" com quase 55\% das ocorrências. Na visão de alguns especialistas, uma marca pode não ter uma tabela de medidas padrão, mas ela precisa informar aos seus usuários quais medidas está usando "Se a marca identifica que ela quer atender um público alvo específico, a única coisa que ela tem que ser, é clara”, “...cada empresa poderia fazer a sua (tabela), claro sendo sensato, transparente pra não vender algo que não condiz", "aí eu não estou seguindo nenhum tipo de tabela anterior, mas eu estou dizendo ali o que eu faço". "Conhecer o público" também revelou-se uma tema importante para os especialistas, $14,3 \%$ das ocorrências.

Dentre as outras unidades de registro, destacam-se também a importância de beneficiar a indústria e o que foi denominado "O fator psicológico das medidas", o vanity sizing (Capítulo 4) quando empresas de vestuário vendem um tamanho maior como se fosse um menor, "Mas na verdade é, ela (marca) sabe que ela tá vendendo 42, mas coloca 38 só pra conseguir vender, porque é uma característica de mulher se sentir bem quando tem uma numeração melhor".

\section{6.}

\section{Seleção do sítio de e-commerce para avaliação}

Para a condução do teste usabilidade, fez-se necessário levantar e selecionar um sítio de vestuário feminino para posterior avaliação. Os respondentes do questionário foram solicitados a citar os 3 sítios mais acessados para realizar compras de vestuário. O sítio www.dafiti.com.br foi o primeiro colocado com 25 citações, seguido do www.aliexpress.com e www.privalia.com.br. De acordo com o Alexa.com, empresa integrante do grupo Amazon.com, e com o relatório da ComScore (2016), o sítio da Dafiti é o mais acessado pelos internautas brasileiros no segmento de vestuário. Além deste critério, o sítio escolhido vende peças de vestuário de diversas marcas, explicitando assim a diversidade e disparidade das 
medidas adotadas por cada uma. Outro ponto importante é o modelo de negócios do sítio Dafiti.com.br, é uma empresa que não possui lojas físicas, portanto não há um local onde os usuários possam ter um contato físico com um produto anterior à compra.

\section{7.}

\section{Observações sobre o Capítulo 5}

Pode concluir-se com base nas verbalizações das entrevistas exploratórias que a confiança é a principal barreira enfrentada pelos consumidores, principalmente no que tange sítios de vestuário. Este é um fator na interação do usuário com o sítio e nos remete tanto às qualidades hedônicas que referem-se à habilidade percebida em dar suporte ao usuário em atingir metas de ser ou estar, relacionadas à UX, quanto às qualidades pragmáticas que referem-se à habilidade percebida do produto em atingir metas de fazer, por sua vez, relacionadas à usabilidade (HASSENZAHL, 2007).

O segmento de Moda e Acessórios apesar de ter sido o líder em volume de vendas ficou na $6^{\mathrm{a}}$ posição em volume financeiro (E-BIT, 2017a). Esse número sugere que os consumidores gastam menos por compra, corroborando as verbalizações da entrevista exploratória, indicando que o preço baixo dirime o risco percebido pelo usuário. Ademais, estudos revelam que os usuários demonstram-se dispostos a arriscarem-se mais ao adquirirem produtos com um baixo valor monetário (KIM; BENBASAT, 2009).

A percepção de risco deve-se principalmente a falta de confiança do usuário em relação ao referencial de medidas das roupas brasileiras que segundo os especialistas entrevistados não seguem o mesmo referencial de medidas e o resultado são peças que deveriam ter mesmo tamanho independente da marca. $\mathrm{O}$ receio de uma peça não ter as medidas adequadas é intensificado pela falta de contato tátil na compra feita por meio da internet e pela falta de informações complementares, tais como as dimensões do produto, material utilizado e políticas de troca, que poderiam trazer mais segurança ao usuário. Existe claramente uma lacuna entre as demandas do usuário por uma padronização dos tamanhos e as opiniões dos especialistas. Em geral, para estes, contanto que as marcas 
divulguem suas tabelas, não há problema em seguir um referencial de tamanhos diferente, pois é muito improvável que atinja-se uma padronização.

A falta de confiança, em alguns casos, impede o cumprimento da tarefa. Além de afetar a usabilidade - eficiência, eficácia e satisfação, a disparidade de medidas e a carência de informações sobre o produto, afetam a experiência do usuário. A UX, abreviação do termo, engloba todos os aspectos da percepção que o usuário final tem quando ele interage com uma empresa e seus produtos e/ou serviços (NORMAN, DONALD A.; NIELSEN, [S.d.]). Esta percepção inclui a eficácia, a eficiência, a satisfação emocional e a qualidade do relacionamento da empresa que criou o produto ou serviço (KUNIAVSKY, 2010).

Estes aspectos específicos de sítios de e-commerce de vestuário independem do dispositivo, ele extrapola a mídia por meio da qual o usuário está acessando o sítio. Não trata-se apenas de adaptações acríticas de sítios completos para sítios móveis, como inicialmente era um dos problemas de pesquisa. A pesquisa exploratória provou ser uma ferramenta investigativa extremamente valiosa para o levantamento de problemas enfrentados por usuários ao tentar comprar roupas online e esclarecedor quanto aos modelos mentais dos mesmos.

As decisões de compra envolvem a identificação correta das informações das peças de vestuário por parte do usuário. Para que as atividades humanas em seus sistemas sejam aperfeiçoadas é preciso observar essa interação (MEMÓRIA, 2005) e assim qualificar a experiência de compra de peças de vestuário do usuário. Para tal, um teste de usabilidade foi aplicado e seus resultados complementaram os dados obtidos na fase de pesquisa exploratória para entender a UX em um teste pessoal, onde o usuário é observado em ação. O teste de usabilidade será pormenorizado no capítulo 6 desta dissertação. 


\section{Práticas metodológicas: pesquisa descritiva}

No capítulo 5 foram apresentadas as práticas metodológicas da fase da pesquisa exploratória. Neste capítulo serão apresentadas as práticas metodológicas da pesquisa descritiva. Com base nos resultados da fase da pesquisa exploratória foi possível determinar as técnicas de pesquisa para alcançar os objetivos descritos no capítulo 1. Foram combinadas algumas técnicas, foi realizado um teste de usabilidade composto de três partes: perguntas de perfil, execução das tarefas desenvolvidas para o teste, um debriefing e a aplicação do questionário AttrakDiff2тM. Posteriormente à realização do teste foi feita uma análise de tarefas utilizando-se o resultado do teste. Todas estas etapas serão expostas em pormenores nos itens a seguir.

\section{1 .}

\section{Teste de usabilidade}

Fundamentado nos pressupostos desta pesquisa, foi realizada a pesquisa descritiva. Uma amostra da população de usuários de e-commerce de vestuário realizou um teste de usabilidade no sítio www.dafiti.com.br.

Para avaliar a experiência do usuário ao comprar uma peça de roupa em um sítio de vestuário feminino foram utilizadas algumas técnicas de pesquisa. Um teste de usabilidade foi realizado composto de três etapas, perguntas de perfil, execução de tarefas, um debriefing e um questionário pós tarefa foi aplicado, o AttrakDiff2 ${ }^{\mathrm{TM}}$.

Os testes de usabilidade têm como foco avaliar a qualidade das interações que se estabelecem entre usuários e sistemas. Seu objetivo é o de verificar possíveis problemas na interação, medir os seus prováveis impactos negativos e identificar suas causas na interface. Um teste de usabilidade envolve usuários reais da população-alvo do sistema interagindo com ele para realizar tarefas 
específicas em um contexto de operação real ou simulado (CYBIS; HOLTZ; FAUST, 2010).

As decisões de compra envolvem a identificação correta das informações das peças de vestuário por parte do usuário. Para que as atividades humanas em seus sistemas sejam aperfeiçoadas, é preciso observar essa interação (MEMÓRIA, 2005). Pesquisadores que observam múltiplos eventos e usuários aprendem a ver as estratégias comuns adotadas por eles para atingir seus objetivos ao trabalharem. Uma vez que as estratégias básicas são compreendidas, é possível começar a projetar um sistema que as apoie (BARBOSA; SILVA, 2010).

Um debriefing é um questionário aplicado pelo moderador do teste após o seu término. Por meio dele é possível entender as impressões dos usuários sobre o sistema, assim como o nível de satisfação com a experiência de uso (NIELSEN, 1993).

\subsection{1.}

\section{Escolha do site a ser avaliado - Pré-análise do dafiti.com.br}

O sítio escolhido para serem executadas as tarefas do teste de usabilidade foi o Dafiti.com.br, alguns motivos foram determinantes para isso. Primeiro sua popularidade, de acordo com os rankings da Alexa.com e da Conversion de junho de 2017 (época em que o sítio foi selecionado) o Dafiti.com.br é o líder em vendas no segmento de vestuário no Brasil. Também foi o sítio mais citado no questionário on-line aplicado na fase da pesquisa exploratória (Capítulo 05).

A Dafiti é um marketplace ${ }^{11}$ on-line brasileiro, líder na América Latina com filiais na Argentina, Chile e Colômbia. Só no Brasil, são comercializadas mais de mil marcas e por volta de 110 mil produtos divididos em seis categorias: roupas, sapatos, acessórios, beleza, cama/mesa/banho e decoração (DAFITI, 2017). Cada produto tem uma descrição textual com o seu nome, a descrição técnica (tipo de tecido, código do item, entre outras informações), identificação do vendedor e imagens que complementam esta descrição. Porém, verificou-se a ausência de um padrão para estas informações, alguns produtos não as apresentam de forma completa.

11 marketplace é um espaço destinado a realizar transações comerciais. O marketspace (ou marketplace online) é um marketplace estendido além das fronteiras tradicionais e removido de uma localização temporal e geográfica (LAUDON; TRAVER, 2016). 
Além de ser a líder de vendas, comercializa produtos de uma gama extensa de marcas - que oferecem uma extensa variação de estilos e modelos - o usuário é estimulado a refletir sobre a questão do tamanho da roupa. O usuário também precisa pensar refletir acerca das suas medidas ao utilizar O FIT FINDER, e ao consultar as diversas tabelas de medidas oferecidas pelo sítio. O FIT FINDER é um aplicativo inserido no sítio com a intenção de oferecer suporte aos usuários na escolha do tamanho adequado de roupas e acessórios. Os usuários são solicitados a responder perguntas como: idade, altura, peso e algumas sobre preferência de marcas e formas do corpo (cintura, quadril, busto), ao final, o aplicativo sugere um tamanho para o usuário utilizando as informações fornecidas. Diversos sítios de marcas nacionais e internacionais, como a Asos.com, utilizam ferramentas similares.

A Dafiti é uma empresa que não possui lojas físicas, consequentemente os usuários não têm acesso aos produtos comercializados antes de serem adquiridos (com exceção às marcas já conhecidas dos usuários).

\subsection{2.}

\section{A estrutura do sítio da Dafiti}

Com o objetivo de entender com mais clareza a execução e os resultados do teste de usabilidade, assim como, a análise de tarefas, a estrutura do sítio da Dafíti será ilustrada utilizando-se impressões de telas. Estas foram feitas por meio de um laptop MacBook Pro 13" e um smartphone iPhone 7 no dia 14/10/2017. Apesar dos testes de usabilidade terem sido executados entre abril e julho e as telas copiadas no mês de outubro, não houve mudanças significativas de navegação ou estruturais. A mesma versão do sítio é acessada tanto por laptops quanto por desktops. Portanto considerou-se necessário apenas apresentar uma destas versões; optou-se pela de um laptop. Só serão descritos os elementos do sítio relevantes para a compreensão do teste de usabilidade.

Os elementos principais da Homepage do sítio da Dafiti são: o Menu Superior, o Menu Lateral e os Banners de Categoria (feminino, masculino, infantil, esporte e casa) (Figura 6.1). Na prática, as categorias do sítio podem ser acessados por meio de uma destas três formas. 


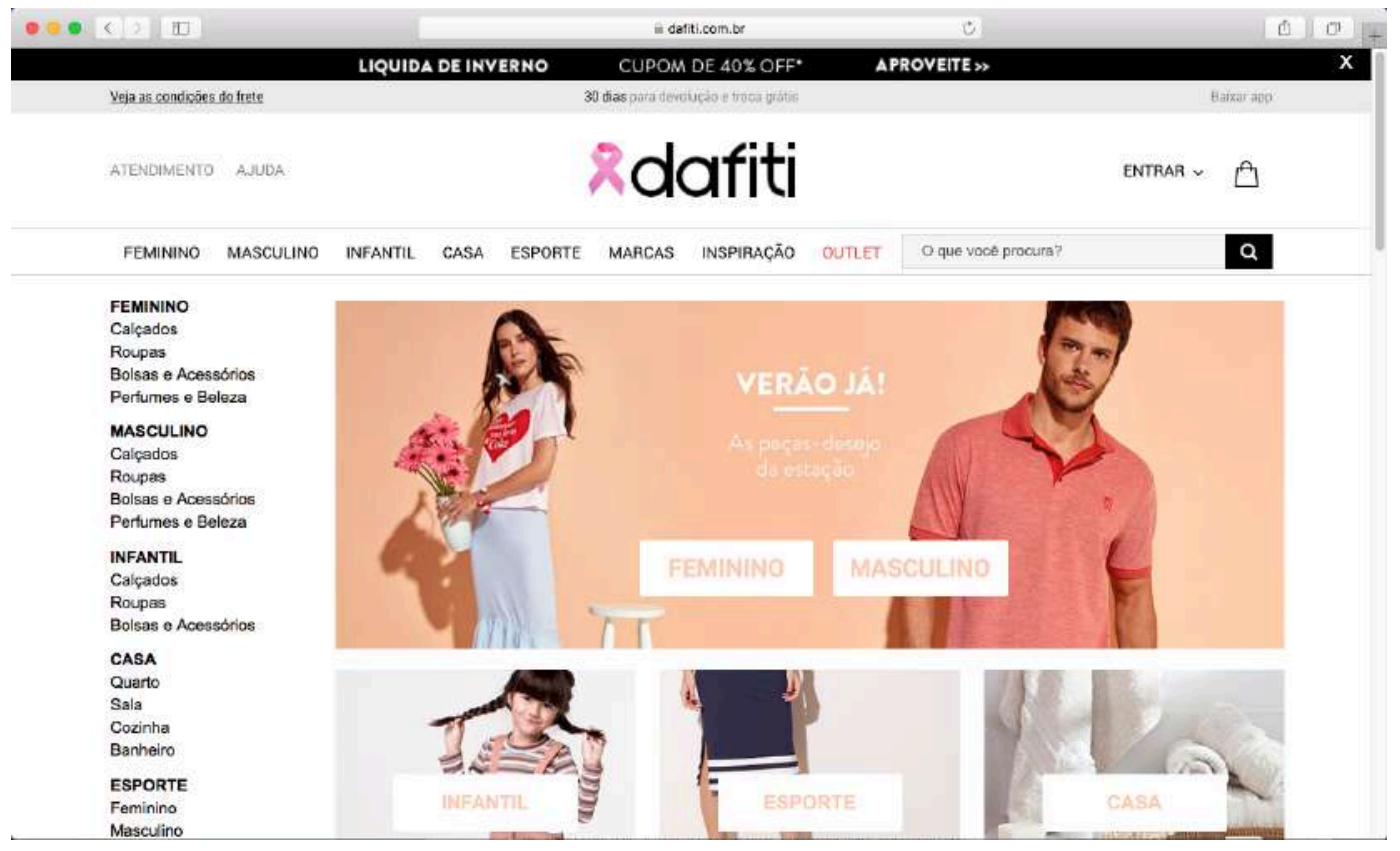

Figura 6.1 - Página home do sítio dafiti.com.br acessado por meio de um laptop. Fonte: https://www.dafiti.com.br.

O Menu Superior pode ser acessado clicando-se sobre as categorias (feminino, masculino, infantil, casa, esporte, marcas, inspiração e outlet) ou utilizando-se o recurso mouseover ${ }^{12}$. Ao passar o cursor do mouse sobre as categorias do Menu Superior um sub-menu é ativado, será referido nesta pesquisa como Menu Mouseover (Figura 6.2).

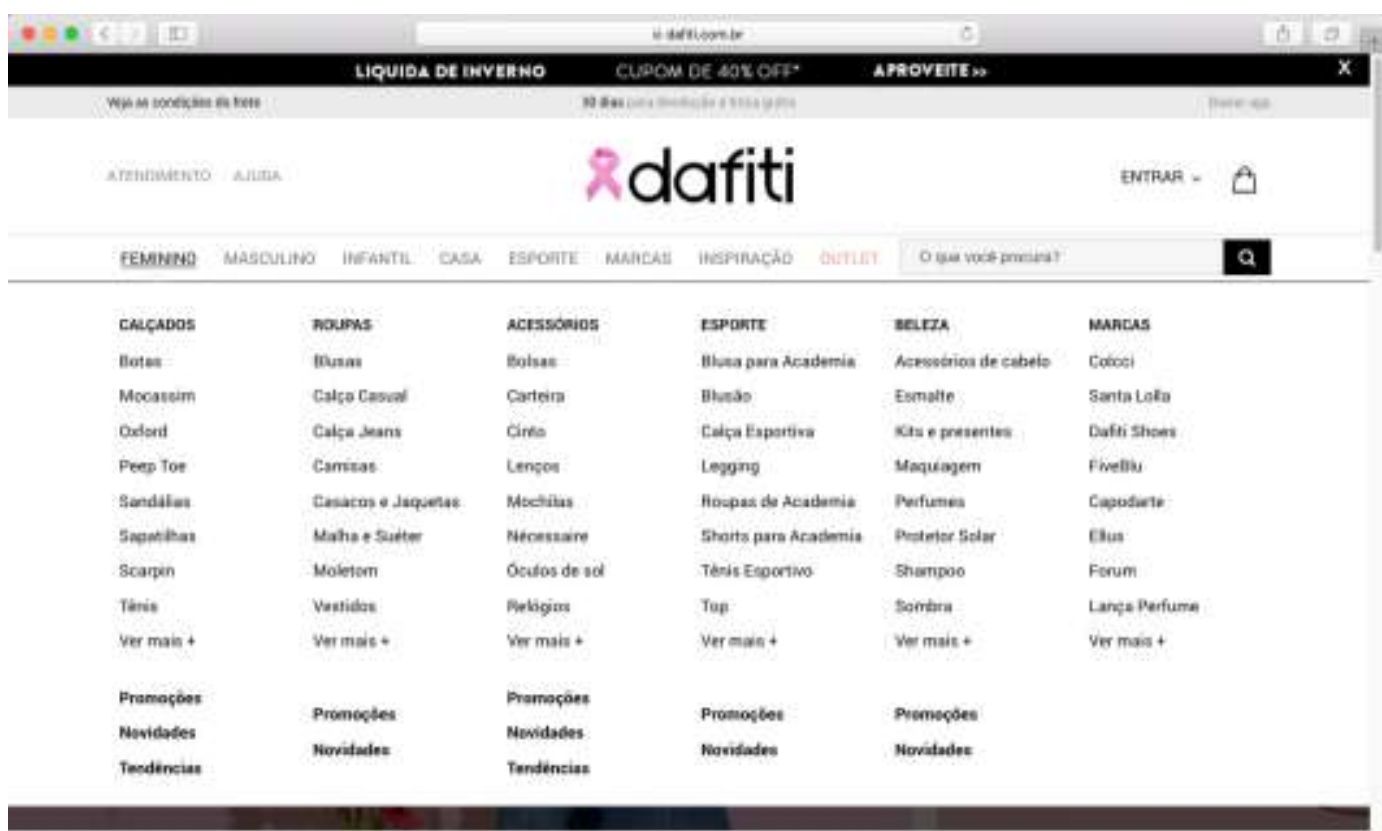

Figura 6.2 - Menu mouseover: um sub-menu ativado por mouseover. Fonte: https://www.dafiti.com.br

${ }^{12}$ Passar o cursor do mouse sobre uma imagem ou um hiperlink. 
Ao clicar na opção Feminino no menu superior, o usuário é levado para a Homepage da Categoria Feminino (Figura 6.3).

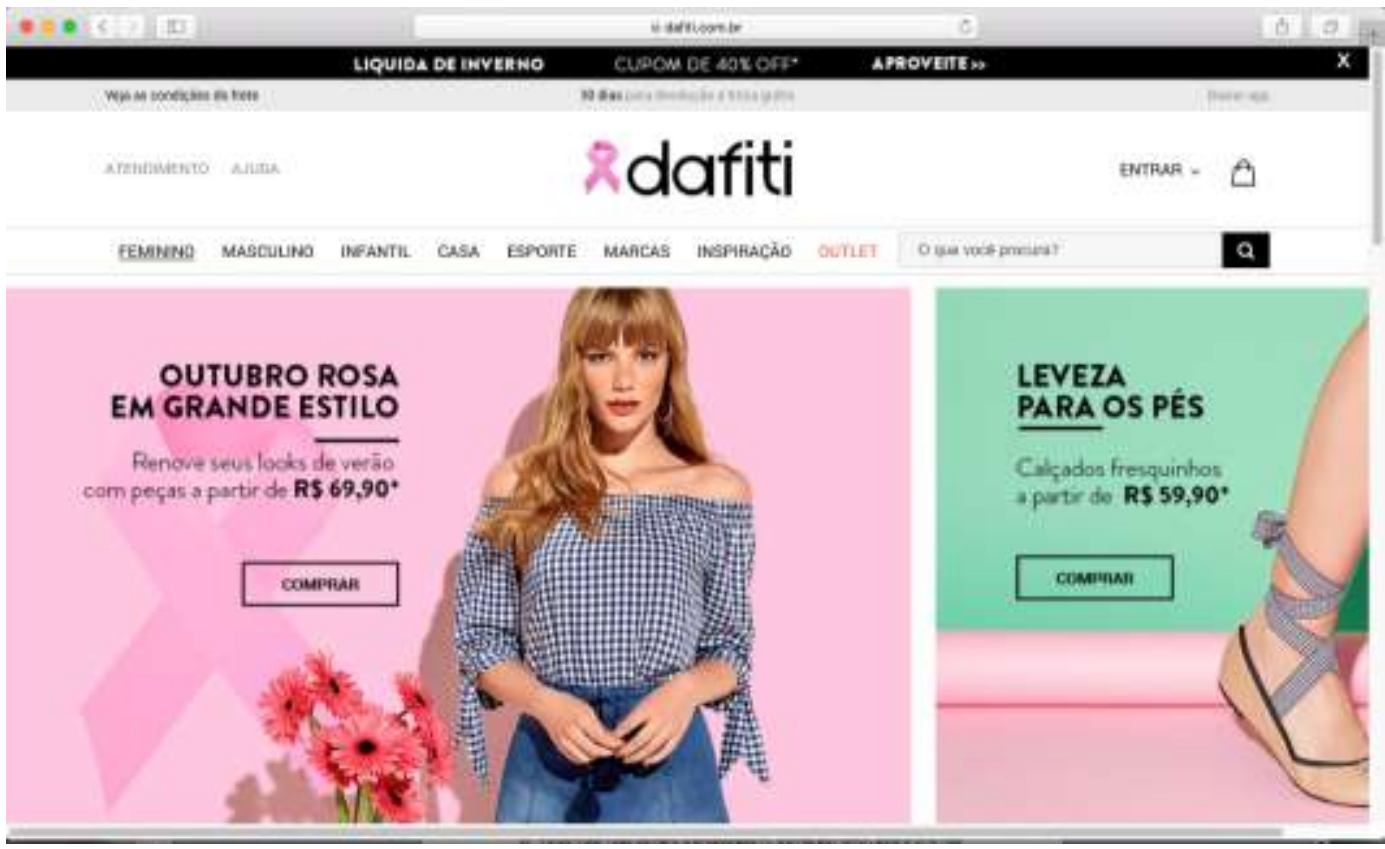

Figura 6.3 - Homepage da categoria feminino. Fonte: https://www.dafiti.com.br/feminino/

No rodapé do sítio da Dafiti existem alguns links úteis para os usuários cumprirem as tarefas do teste de usabilidade, entre eles estão: Políticas de Trocas e Devoluções e Dúvidas Frequentes (Figura 6.4).

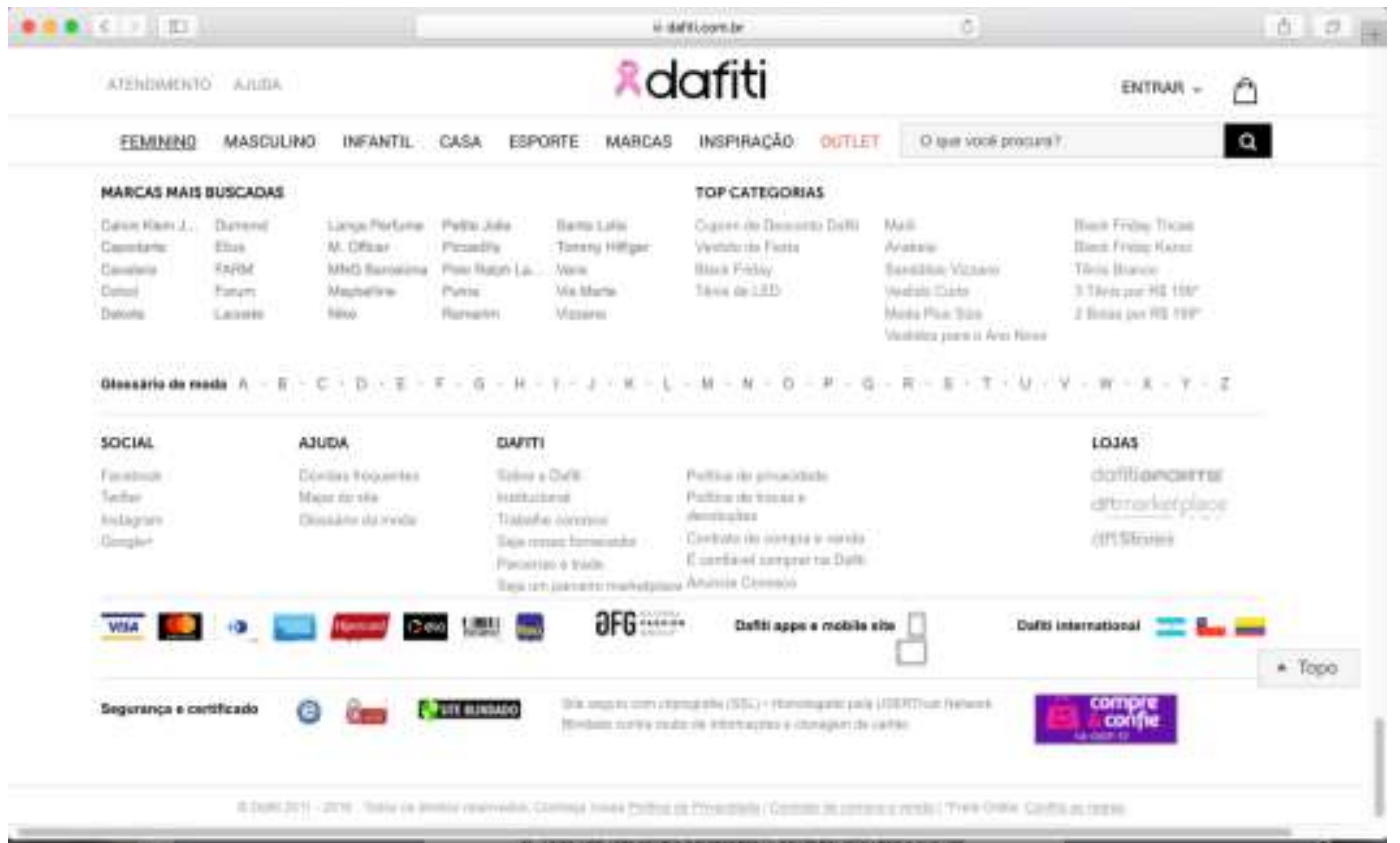

Figura 6.4 - Rodapé do sítio da Dafiti. Fonte: https://www.dafiti.com.br 
Ao selecionar uma categoria de produtos, o usuário é levado para a Página de Produtos (Figura 6.5), em que os produtos da categoria selecionada são exibidos para que sejam explorados e eventualmente selecionados para a visualização dos pormenores. Na lateral esquerda, estão os Filtros de Busca. O usuário pode refinar a sua pesquisa filtrando-os por: tipo da peça (blusa de manga curta, blusa de manga longa, etc.), tamanho, marca, cores, preços, lojas, tipo de decote, tipo de lavagem, frete adicional, ocasião e tendências. Também é possível ordenar os produtos por: popularidade, ordem alfabética, marca e preço utilizando-se do filtro no topo da página do lado direito. Ambos os filtros estão sinalizados com uma caixa vermelha na Figura 6.5.

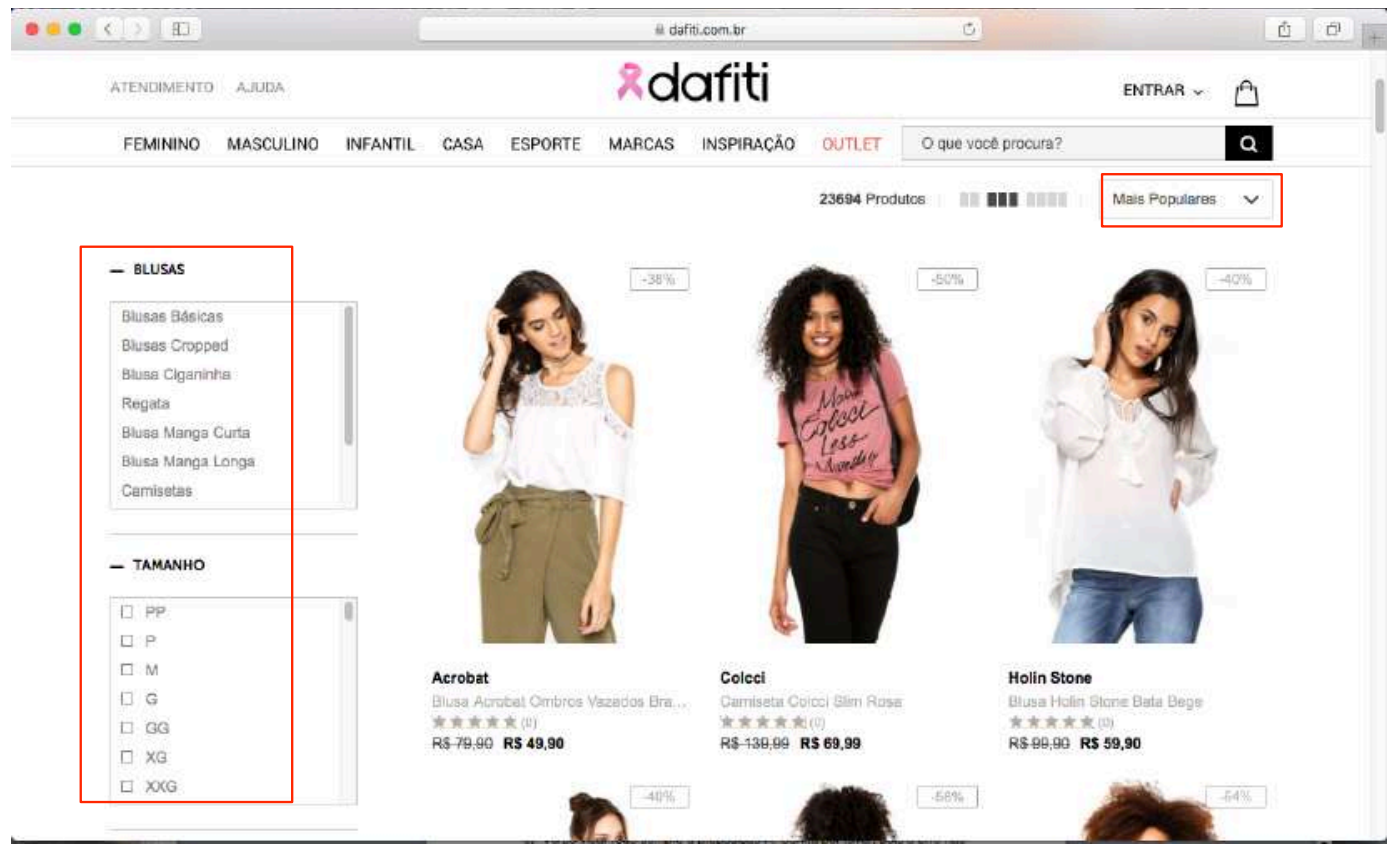

Figura 6.5 - Página de Produtos do sítio da Dafiti. Fonte: https://www.dafiti.com.br

Ao clicar sobre a imagem de um produto, na Página de Produtos, o usuário é levado à Página do Produto (Figura 6.6). Lá é possível acessar sua descrição, e especificidades da peça, tais como: tipo de tecido, composição do tecido, medidas da peça entre outros. Como já mencionado anteriormente, não há um padrão, alguns produtos apresentam informações bastante completas como na Figura 6.7, porém outros não fornecem tantos dados.

Na Página do Produto também seleciona-se o tamanho e opta-se por comprá-lo ao clicar no botão "comprar". 


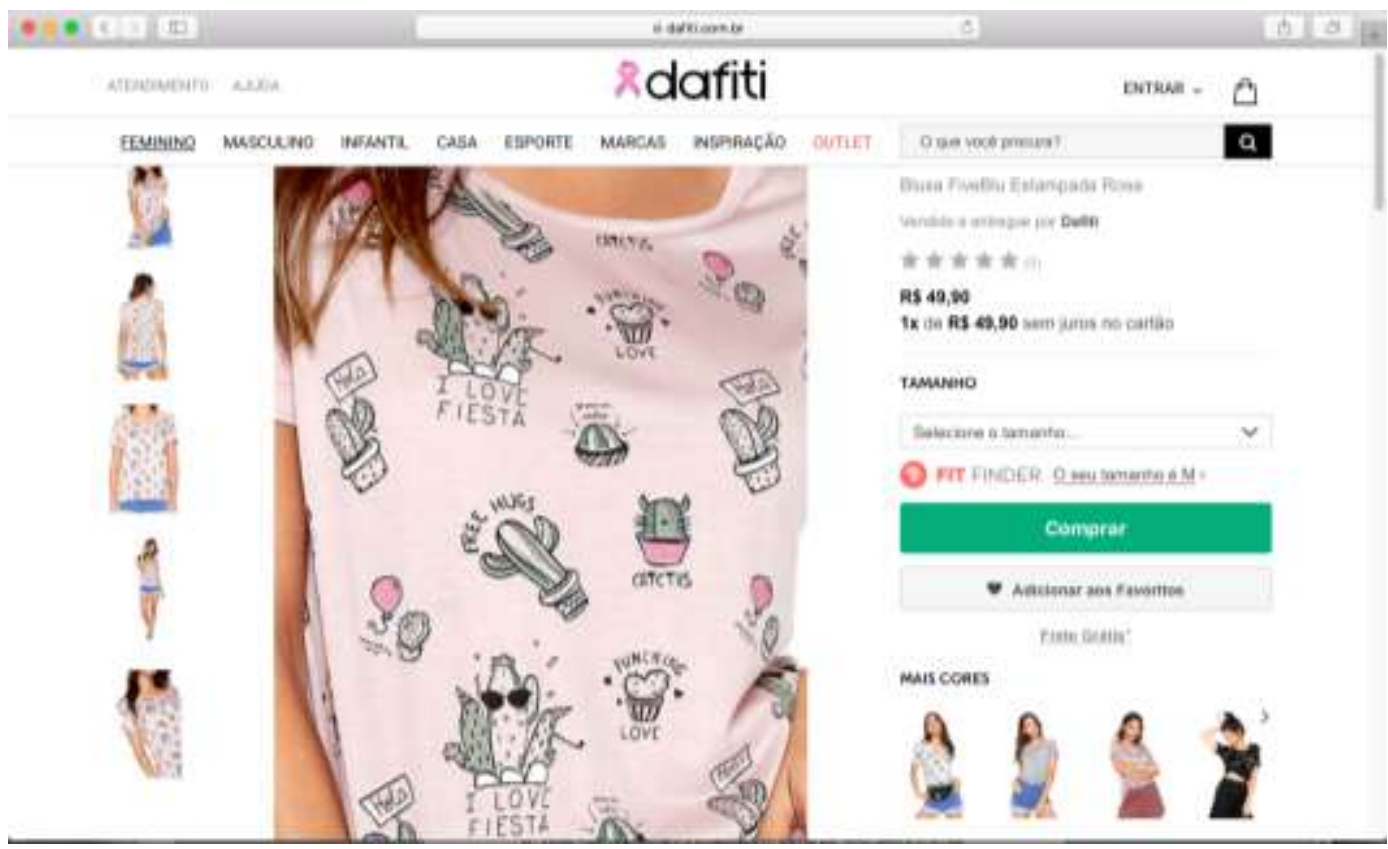

Figura 6.6 - Página do Produto do sítio da Dafiti. Fonte: https://www.dafiti.com.br

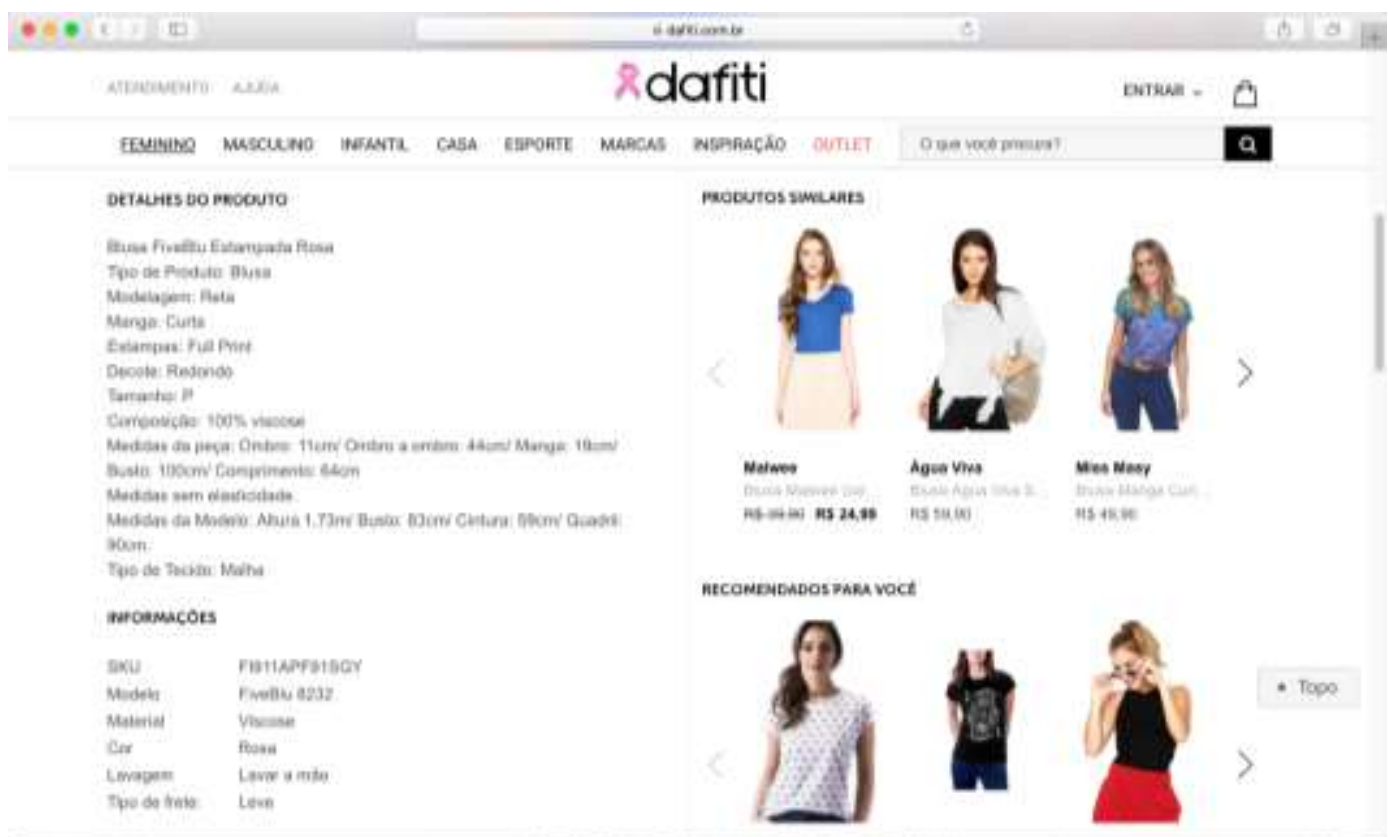

Figura 6.7 - Detalhes do produto na Página do Produto no sítio da Dafiti. Fonte: https://www.dafiti.com.br

O sítio da Dafiti não é responsivo, existe uma versão elaborada especialmente para ser acessada por dispositivos móveis, esta é considerada a melhor solução por Nielsen e Budiu (2014), os autores sugerem criar um sítio separado otimizado para os dispositivos móveis.

A seguir, será apresentada a estrutura do sítio móvel. Adota-se a mesma programação visual, mas existem diferenças na navegação das duas versões. $\mathrm{Na}$ Homepage do sítio móvel (Figura 6.8) pode acessar-se as categorias dos produtos clicando nos banners ou por meio do menu hambúrguer. 

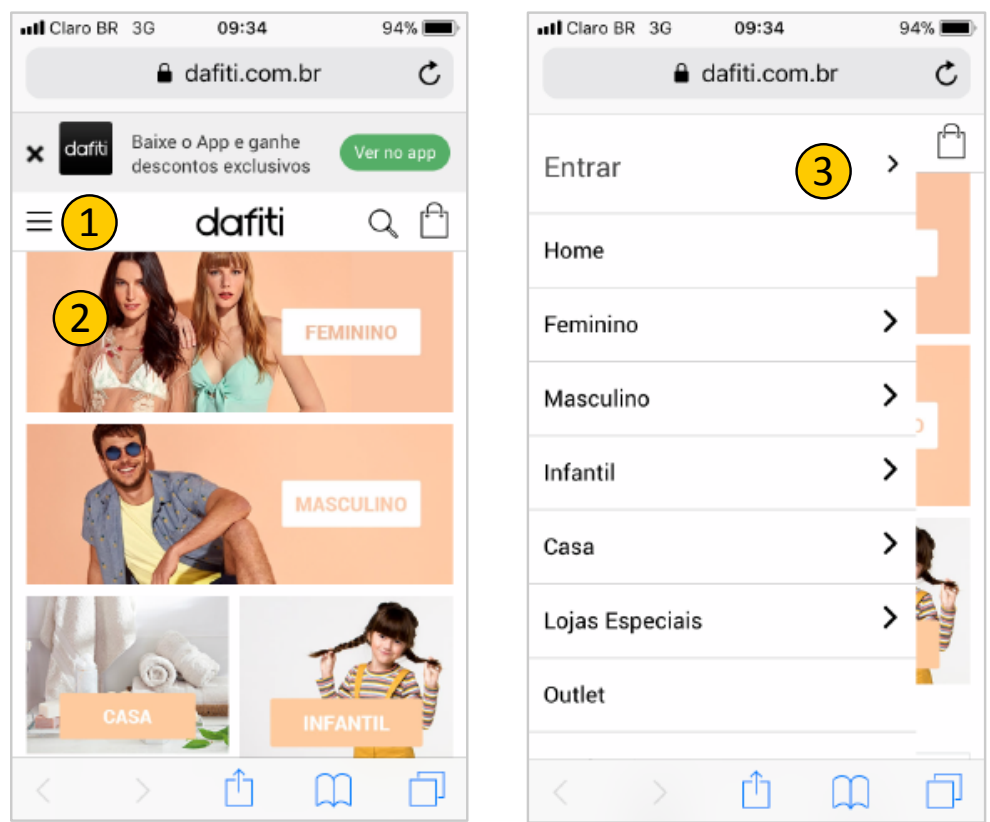

1 - Menu hambúrguer

2 - Banner feminino

3 - Menu hambúrguer estendido

Figura 6.8 - Homepage do sítio móvel da Dafiti. Fonte: Fonte: https://www.dafiti.com.br

Após selecionar uma categoria (feminino, masculino, casa, infantil, outlet ou esporte) o usuário é levado à Página dos Produtos (Figura 6.9). O usuário pode refinar a busca clicando no botão Filtrar na parte superior da Página dos Produtos, (Figura 6.9). Como na versão completa (para desktop e laptops), os produtos podem ser ordenados por preço, popularidade, ordem alfabética e marca, clicando-se no botão ao lado do botão "Filtrar".
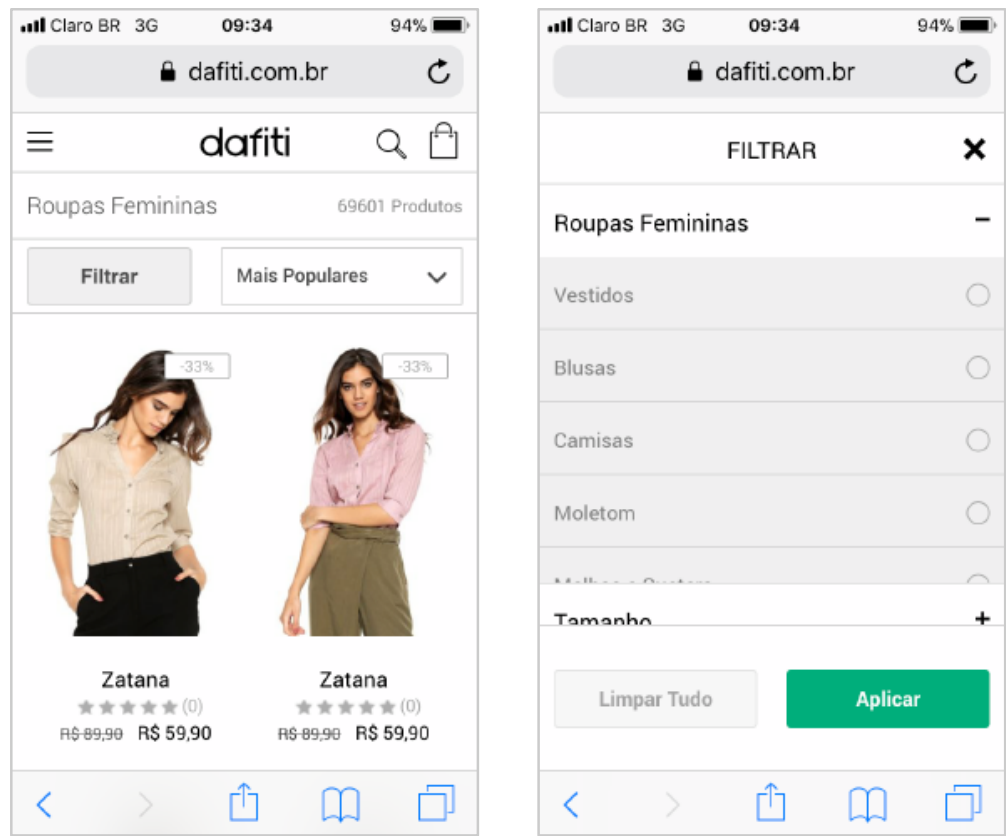

Imagem à esquerda: página de produtos Imagem à direita: filtros

Figura 6.9 - Página de Produtos (esq.) e Página de Filtros do sítio móvel da Dafiti. Fonte: www.dafiti.com.br. 
Ao clicar-se sobre a imagem de um produto, na Página de Produtos, o usuário é levado à Página do Produto (Figura 6.10). Como na versão completa, é possível acessar sua descrição e detalhes tais como: tipo de tecido, composição do tecido, medidas da peça, entre outros. Os detalhes de produto, assim como as avaliações, estão ocultos, o usuário precisa clicar na opção "Detalhes do Produto" para que a caixa se expanda e se tenha acesso as informações do produto (Figura 6.10).
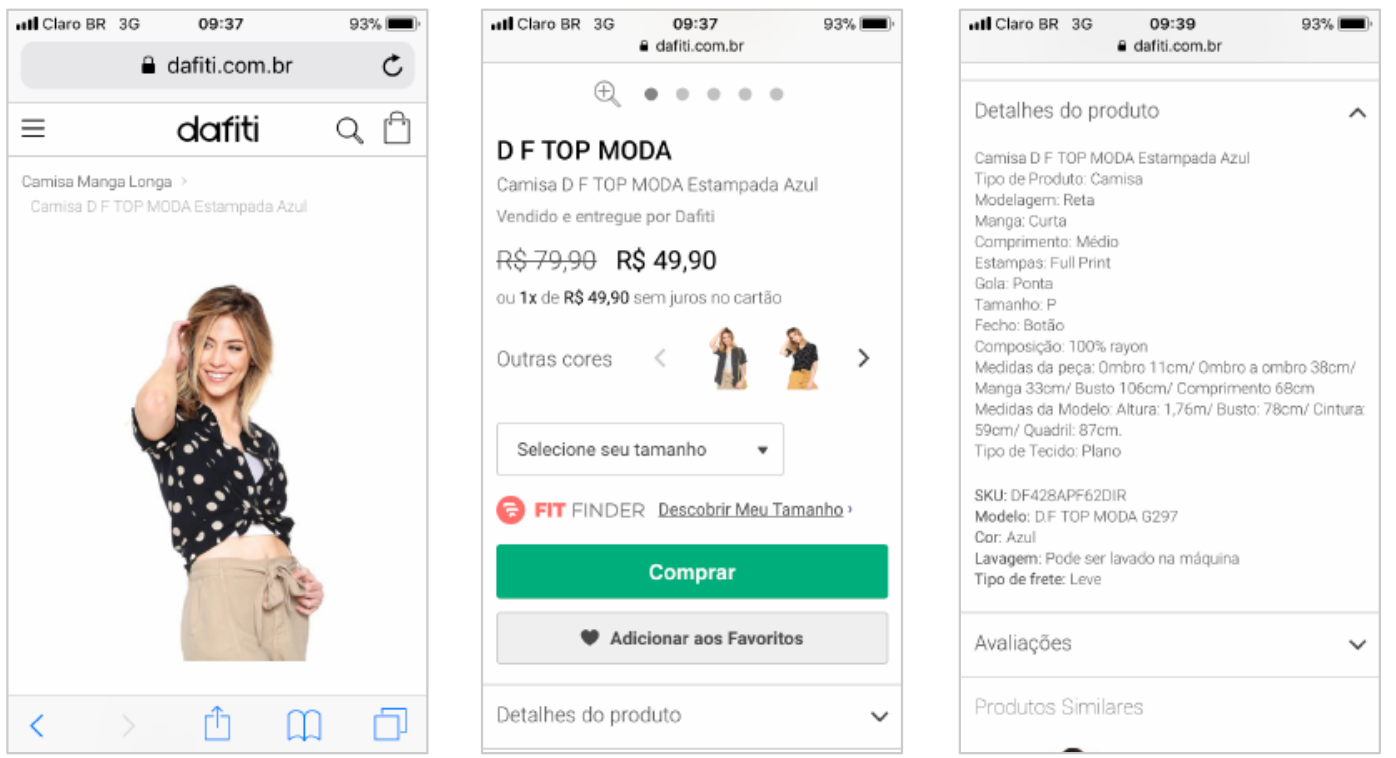

Da esquerda para a direita: página do produto, continuação da página do produto e detalhes do produto expandido.

Figura 6.10 - Página de apresentação do produto do sítio móvel da Dafiti. Fonte: www.dafiti.com.br.

No rodapé da versão móvel do sítio da Dafiti também existem alguns links úteis para os usuários, entre eles estão: "Dúvidas" e "30 dias para troca e devolução grátis", os dois links levam o usuário à página de "Dúvidas Frequentes" (Figura 6.11). Na versão móvel, existem menos opções de links no rodapé do que na versão completa, obedecendo as sugestões de simplificar as versões de páginas para serem acessadas por dispositivos móveis feitas por Nielsen e Budiu (2014) (Capítulo 3). 


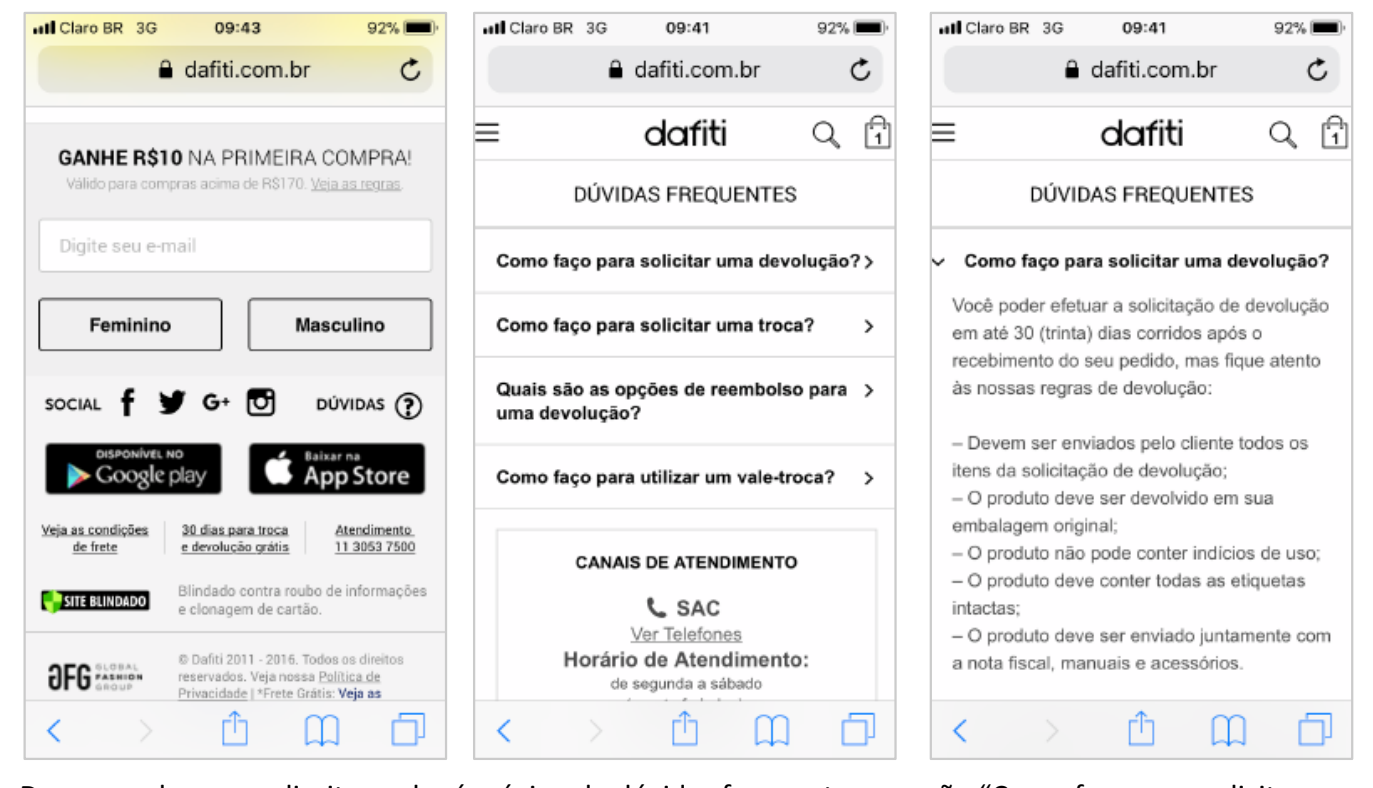

Da esquerda para a direita: rodapé, página de dúvidas frequentes e opção "Como faço para solicitar uma devolução" expandida.

Figura 6.11 - Rodapé e página de dúvidas frequentes do sítio dafiti.com.br acessado por meio de um smartphone. Fonte: Elaborado pela autora.

\subsection{3.}

\section{Tarefas do teste de usabilidade}

Com base nos resultados do questionário on-line e nas questões abordadas pela literatura sobre os problemas vivenciados por usuários ao interagir com sítios de e-commerce, (Capítulo 3), chegou-se aos objetivos do teste de usabilidade. Eles serão expostos a seguir.

\section{Avaliar a clareza das informações expostas na(s) tabela(s) de medidas}

Os resultados da entrevista exploratória (Capítulo 5) mostraram que a confiança nas informações apresentadas e representadas por sítios de e-commerce são a razão fundamental que impede os consumidores de realizar compras de vestuário on-line. $\mathrm{O}$ receio de que uma peça não caiba ou que não tenha um bom caimento e a dificuldade percebida para realizar trocas e devoluções são fatores impeditivos. A questão das medidas também foi intensamente abordada pelos respondentes do questionário on-line (Capítulo 5), 81\% declararam que não compram on-line, pois não sabem se a roupa irá caber-lhe e $87 \%$ por terem dúvida quanto ao caimento da peça. Conforme foi abordado no Capítulo 4, a questão das medidas é uma das principais reclamações dos e-shoppers e dos consumidores de vestuário em geral 
e faz-se essencial investigar a maneira como os usuários lidam com esta informação e como são lhes apresentadas.

2. Avaliar o findability (facilidade de encontrar) da(s) tabela(s) de medidas e;

3. Examinar como a descrição do produto (ou sua ausência) influenciam na decisão de compra do usuário (Os objetivos 2 e 3 foram agrupados, pois ambos tratam da busca de informações sobre o produto).

A busca por informações é parte do processo decisório de compra, (KOTLER; KELLER, 2016; SOLOMON, 2011), quando os consumidores têm a intenção de comprar algo, analisarão a marca e as características do produto (LAUDON; TRAVER, 2016). O grau de conhecimento que o consumidor tem sobre um produto influencia diretamente o seu comportamento de compra (LAUDON; TRAVER, 2016; NIELSEN, 2000) assim como a intangibilidade do produto on-line e a falta de segurança podem desestimulá-los. Por outro lado, se estiverem bem informados a respeito do produto sentem-se mais propensos à efetuar uma compra conforme Katawetawaraks e Wang (2011).

O conteúdo informativo de um sítio de moda a respeito de um produto pode ser classificado em 5 grupos (MAGRATH; MCCORMICK, 2013):

1. Informações práticas do produto - são a cor, preço, cuidados especiais, tamanho, etc. Elas descrevem o produto e são essenciais para o entendimento do consumidor e contribuem para sua satisfação com a interação e para que haja uma percepção de confiança mais elevada;

2. Informações práticas sobre serviços - entre elas estão os endereços das lojas físicas (quando existem), preço do frete, política de trocas e devoluções;

3. Informações de tendências - atualizam o consumidor sobre as últimas tendências de moda;

4. Dicas de estilo - dicas e conselhos de combinações de peças de roupas e acessórios; e

5. Mídias sociais - informações que são integradas às mídias sociais e podem ser compartilhadas.

As informações a serem consideradas no teste de usabilidade são aquelas referentes ao produto (e aos serviços oferecidos pelo sítio no objetivo 6), são elas:

d) o tipo e a composição do(s) tecido(s);

e) caimento; 
f) $\operatorname{cor}(\mathrm{es})$,

g) dimensões;

h) elementos que dão mais informação acerca do produto como: as fotos dos produtos, o tamanho da modelo nas fotos e o tamanho da peça que a modelo.

\section{Compreender a influência do preço do produto na decisão de compra}

Por causa da falta de contato tátil com o produto anterior à compra, os consumidores têm uma sensação maior de risco ao adquirir produtos e serviços on-line. Kim e Benbasat (2009) relacionam o risco ao investimento financeiro, ou seja, quanto maior for o investimento financeiro mais o conteúdo de um sítio precisa despertar a confiança do usuário, este pressuposto é reforçado pelos resultados da entrevista exploratória e do questionário on-line (Capítulo 5).

\section{Compreender a influência do modelo da peça na decisão de compra}

A modelagem de uma peça de vestuário e o tipo de peça (blusa, camisa, calça, etc.) afetarão como a roupa ajusta-se ao corpo. Uma peça pode ser baseada em uma modelagem mais justa ao corpo que requer um grande número de tamanhos para atender à toda a gama de medidas corporais e tipos de corpos dos consumidores; ou mais solta, podendo atender satisfatoriamente ao mesmo grupo de consumidores com uma quantidade menor de opções de tamanhos (CHUN, 2007).

Para fins de esclarecimento, de acordo com a Encyclopedia of Clothing and Fashion (STEELE, 2005) uma camisa é uma peça de vestuário usada na parte superior do corpo, geralmente consiste em uma frente abotoada, gola, punho e pode ter mangas longas ou curtas. Muitos estilos de camisa, anteriormente exclusivamente masculinos, foram adotados essencialmente inalterados para o uso feminino ao final do século XX. O The Dictionary of fashion history (CUMMING; CUNNINGTON; CUNNINGTON, 2010) define uma blusa como uma peça separada usada na parte de cima do corpo de tecido diferente da saia, originalmente era sempre usada com um cinto, e com ou sem uma jaqueta sobre ela. Sua forma inicial foi a camisa Garibaldi criada em 1863. Originalmente voltada para o uso diurno, mas em 1895 as blusas para noite foram introduzidas. No século XX, as blusas começaram a serem confeccionadas em vários estilos diferentes, soltos ou apertados, de manga comprida ou curta, com ou sem golas. Atualmente uma blusa é considerada qualquer parte de cima do vestuário 
feminino, excluindo casacos, blazers e camisas, estas têm uma definição mais específica como exposto acima.

Logo a seguir, com o intuito de ilustrar a complexidade de uma modelagem de camisa comparada a uma de uma blusa, encontram-se os exemplos de uma base de modelagem de cada qual (Figuras 6.12 e 6.13). Para o desenvolvimento de uma base de camisa são consideradas mais medidas do que para uma blusa. Somase a isso a falta de elasticidade comum aos tecidos planos normalmente utilizados para confeccionar camisas, ademais esta é uma peça que demanda serem as medidas utilizadas como referência exatas para obter-se um caimento e uma vestibilidade satisfatória aos consumidores.
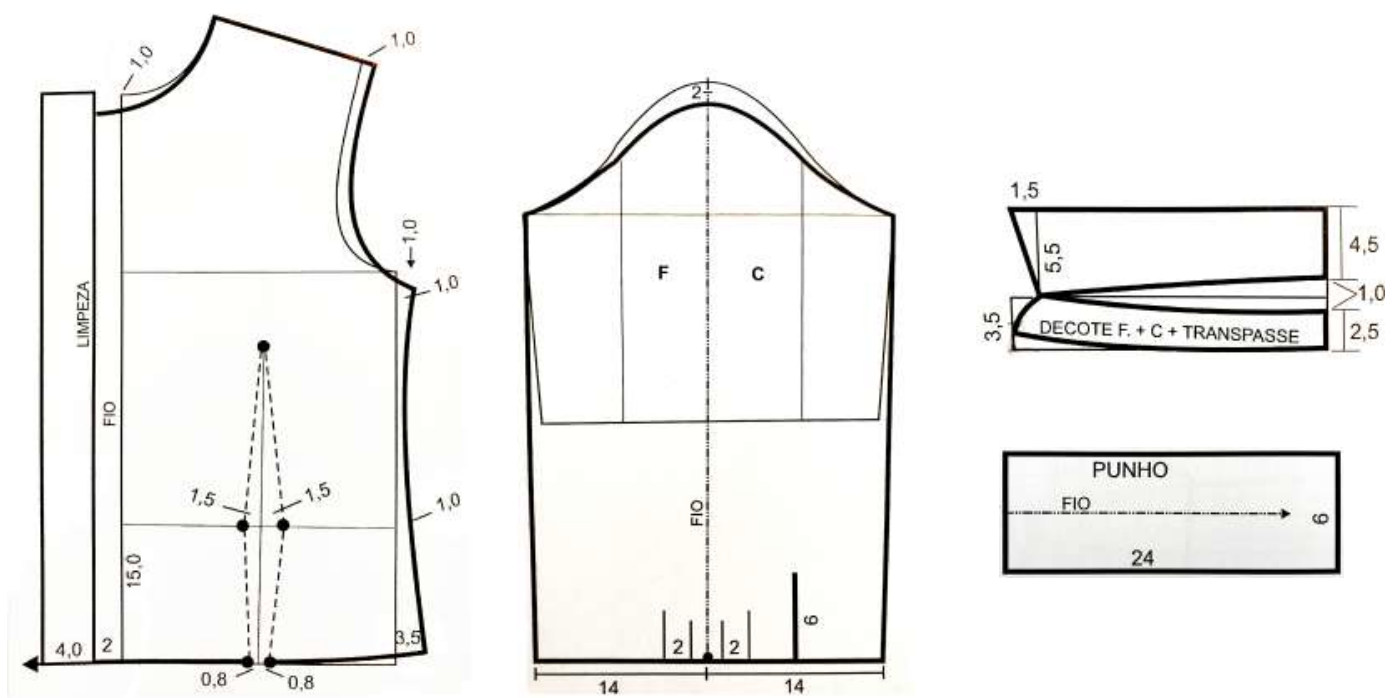

Figura 6.12 - Exemplo de base de camisa feminina. Fonte: (CAVALHEIRO; SILVA, 2003: p. 56-59).
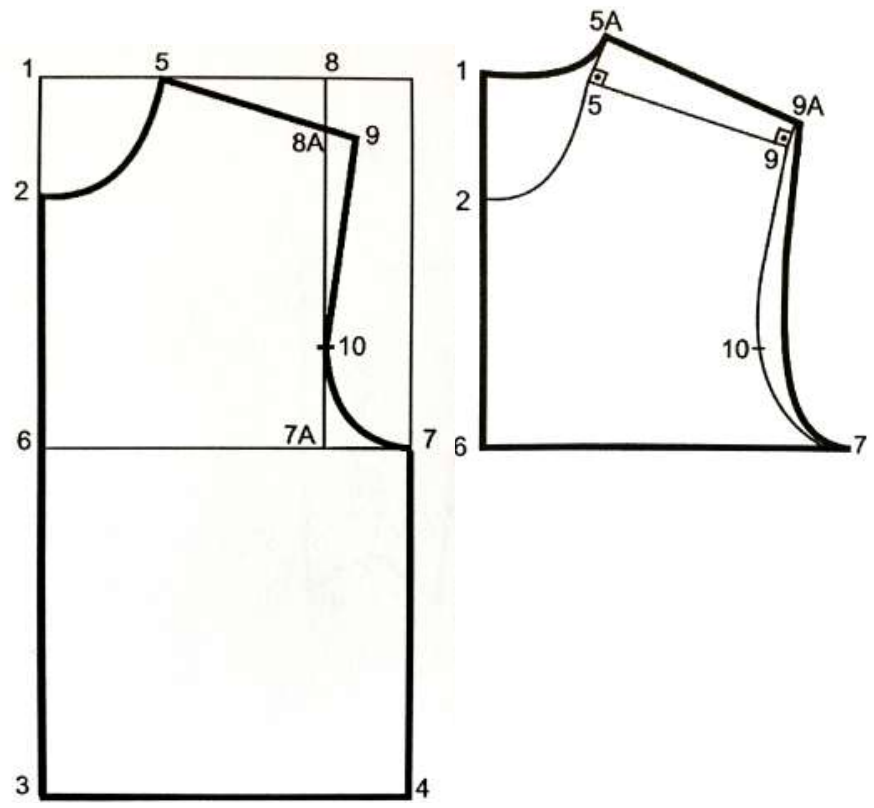

Figura 6.13 - Exemplo de base de blusa feminina. Fonte: (CAVALHEIRO; SILVA, 2003: p. $24-$ 25). 
O material com o qual a peça é confeccionada é um outro ponto a considerar-se: a forma como os tecidos de malha são confeccionados os torna mais elásticos, proporcionando o bom caimento e a sensação de conforto que normalmente os caracteriza (MARTINS; LOPES, 2014). Os tecidos de malha adaptam-se facilmente as partes salientes do corpo, não sendo necessária a utilização de pences ou folgas (ARAÚJO, 1996). Portanto, ao elaborar a tarefa do teste de usabilidade para cumprir este objetivo foi solicitado às usuárias a comprar uma blusa de malha e uma camisa de trabalho (social). As blusas de malha usualmente são mais soltas e adaptam-se com mais facilidade ao corpo, as camisas sociais são mais ajustadas e geralmente produzidas em tecido plano que requer uma gama maior de opções de tamanhos para que se os vista bem.

6. Avaliar o findability (facilidade de encontrar) da política de troca dos produtos e se a mesma é facilitada para o usuário

Características como a textura do tecido e caimento são dificilmente transmitidas digitalmente, estas características são classificadas por Lal e Sarvary (1999) como atributos não digitais de um produto, as peças de vestuário requerem um contato multissensorial, tátil e visual, para serem avaliadas completamente pelos consumidores. Verifica-se que essa falta de contato direta antes da aquisição pode levar a um menor grau de satisfação do consumidor no processo de compra e a uma maior percepção de risco (BLÁZQUEZ, 2014). Por conseguinte, os consumidores desenvolvem mecanismos para abrandar o impacto do risco percebido e suas consequências negativas, um deles é informar-se sobre as garantias oferecidas pelas marcas com as quais interagem (KOTLER; KELLER, 2016; SOLOMON, 2011). Uma política de trocas e devoluções clara e facilitada, por exemplo, pode contribuir para melhorar a experiência do usuário e aumentar a sua confiança.

Um grupo de tarefas foi desenvolvido com base nos objetivos supracitados. As tarefas do piloto do teste de usabilidade estão listadas abaixo (Tabela 6.1). 


\begin{tabular}{|c|c|c|}
\hline Cenário & Descrição da Tarefa & Objetivos \\
\hline 1 & $\begin{array}{l}\text { Em alguns dias você irá sair de férias e precisa } \\
\text { comprar uma blusa de malha para levar na } \\
\text { sua viagem à praia. Você opta por fazer essa } \\
\text { compra em um sítio de comércio eletrônico, o } \\
\text { www.dafiti.com. }\end{array}$ & $1,2,3$ e 5 \\
\hline 2 & $\begin{array}{l}\text { Você irá iniciar um novo trabalho e para } \\
\text { causar uma boa impressão quer comprar uma } \\
\text { camisa social nova. Para deixar tudo em dia } \\
\text { no seu emprego atual, você está sem tempo } \\
\text { de ir à uma loja física, então você opta por } \\
\text { fazer essa compra em um sítio de comércio } \\
\text { eletrônico, o www.dafiti.com }\end{array}$ & $1,2,3$ e 5 \\
\hline 3 & $\begin{array}{l}\text { Ao procurar uma blusa de malha para levar na } \\
\text { sua viagem de férias você fica em dúvida } \\
\text { entre dois produtos, a blusa A e a blusa B. } \\
\text { Escolha entre os dois produtos. }\end{array}$ & 4 \\
\hline 4 & $\begin{array}{l}\text { A blusa que comprou para sua viagem } \\
\text { chegou, porém ao experimentá-la, você não } \\
\text { gostou do caimento além de não ser do } \\
\text { tamanho ideal. Descubra como trocá-la. }\end{array}$ & 6 \\
\hline
\end{tabular}

Quadro 6.1 - Cenários utilizados no teste de usabilidade e seus objetivos. Fonte: elaborado pela autora.

\section{Testes piloto:}

Recrutar e agendar efetivamente participantes requer esforço, por este motivo é importante que as sessões de teste funcionem bem tanto para o pesquisador quanto para os participantes (BARNUM, 2011). Os testes pilotos são valiosos para certificar-se de que seus materiais são claros e compreensíveis, que nenhuma tarefa importante foi esquecida e que o material a ser usado está em ordem e pronto para ser utilizado. Durante os testes pilotos o objetivo ainda não é o de recolher informações sobre usabilidade (RUBIN; CHISNELL, 2008).

Foram realizados 6 testes pilotos entre os dias 20/01/17 e 20/03/2017, 3 em desktop/laptop e 3 em smartphones. A finalidade para realiza-los era a de verificar a duração do teste, refinar os métodos de coleta de dados e resolver quaisquer ambiguidades com as instruções e testar as ferramentas de coleta de dados. O primeiro piloto foi realizado utilizando-se da técnica de entrevista contextual. Percebeu-se que ao longo da execução dos testes as perguntas nem sempre eram pertinentes à tarefa sendo realizada e, portanto, haveria a necessidade de trocar as perguntas para cada usuário. Optou-se por realizar um debriefing ao final do cumprimento das tarefas. 
Uma simulação das tarefas foi realizada com a orientadora desta dissertação para fazer melhorias e ajustes ao teste de usabilidade. Desta forma, as tarefas puderam ser aperfeiçoadas e como consequência a terceira foi substituída. Foi necessário especificar mais a descrição das peças a serem "compradas" pelas voluntárias durante o teste de usabilidade. Notou-se no primeiro piloto que uma descrição muito vaga resultou em retardar em demasia o processo de escolha de peças para realizar as tarefas de simulação de compra no sítio.

Os cenários finais foram:

1. Em alguns dias você irá sair de férias e precisa comprar uma blusa de manga curta de malha, no valor de até $\mathrm{R} \$ 50,00$ (cinquenta reais) para levar na sua viagem à praia. Por comodidade, você opta por fazer essa compra em um sítio de e-commerce, o www.dafiti.com.br

2. Você irá iniciar um novo trabalho e para causar uma boa impressão quer comprar uma camisa manga longa nova, no valor de até R \$100,00 (cem reais). Para deixar tudo em dia no seu emprego atual, você está sem tempo de ir à uma loja física, então você opta por fazer essa compra em um sítio de e-commerce, o www.dafiti.com.

3. A blusa que comprou para sua viagem chegou, porém ao experimentá-la, você não gostou do caimento além de não ser do tamanho ideal. Descubra como devolvê-la.

4. Para ter certeza do seu tamanho, consulte o guia de tamanhos.

Algumas informações foram incluídas no debriefing:

a) Uma opção para sinalizar se o teste fora realizado em desktop/laptop ou smartphone,

b) Uma opção para identificar o modelo do smartphone utilizado no teste;

c) Uma opção para sinalizar se a voluntária já navegara no sítio da dafiti.com.br;

d) Uma escala tipo likert de 7 pontos foi incluída para a voluntária marcar se informações fornecidas pelo sítio foram suficientes (7) até insuficientes (1);

e) Foram incluídas as opções sim/não e por quê para as seguintes perguntas:

f) A tabela/guia de medidas contém informações claras? 
g) Você sente-se segura em relação as informações sobre o caimento da peça?

h) Com base nas informações disponíveis você tem segurança de que o tamanho escolhido está correto?

i) A pergunta: “O preço é um fator decisório de compra?” foi mudada para: "Geralmente, quando você compra on-line o preço é um fator decisório de compra?";

j) A pergunta: "Você finalizaria essa compra? Por quê?" foi retirada;

k) Foram incluídas opções para as voluntárias assinalarem a sua frequência de compra on-line;

1) Depois da realização dos 6 pilotos, foram incluídas as perguntas: "Você já comprou roupa on-line?" e "Como você escolheu o seu tamanho?"

Também foram incluídas perguntas para coleta de informações do perfil das voluntárias como o bairro, cidade e estado de residência das voluntárias.

\subsection{4.}

\section{Execução do teste de usabilidade}

Os testes foram todos realizados em campo; em locais familiares às voluntárias como por exemplo na PUC-Rio, em suas casas ou em seus locais de trabalho e foram gravados utilizando-se a câmera de um celular iPhone 6 Plus e um tablet iPad Mini 2. As voluntárias eram indagadas a respeito do seu dispositivo preferencial para realizar compras on-line, se era em um desktop/laptop ou em um smartphone. Elas realizavam o teste no próprio smartphone, ou em um desktop/laptop com o qual tivessem familiarizadas, poderia ser o do trabalho, o de casa. Esse critério foi adotado para que as voluntárias não tivessem que aprender a usar o dispositivo.

Antes de realizarem o teste, as voluntárias eram solicitadas a lerem e assinarem um Termo de Consentimento e Livre Esclarecimento (Apêndice 3), após sua assinatura, eram feitas algumas perguntas de perfil (Apêndice 3). Em seguida, eram apresentadas por escrito as quatro tarefas (Apêndice 3) a serem realizadas no sítio da empresa Dafiti. As voluntárias eram solicitadas a realizar uma tarefa de cada vez na ordem exposta. Elas podiam tirar dúvidas para 
esclarecer o conteúdo das tarefas mas não sobre como executá-las. Assim que as voluntárias terminavam as tarefas era realizado um debriefing para avaliar a sua percepção a respeito do teste de usabilidade e por fim era aplicado o questionário AttrakDiff2 ${ }^{\mathrm{TM}}$. A ordem das etapas do teste de usabilidade está ilustrada na Figura 6.14 .

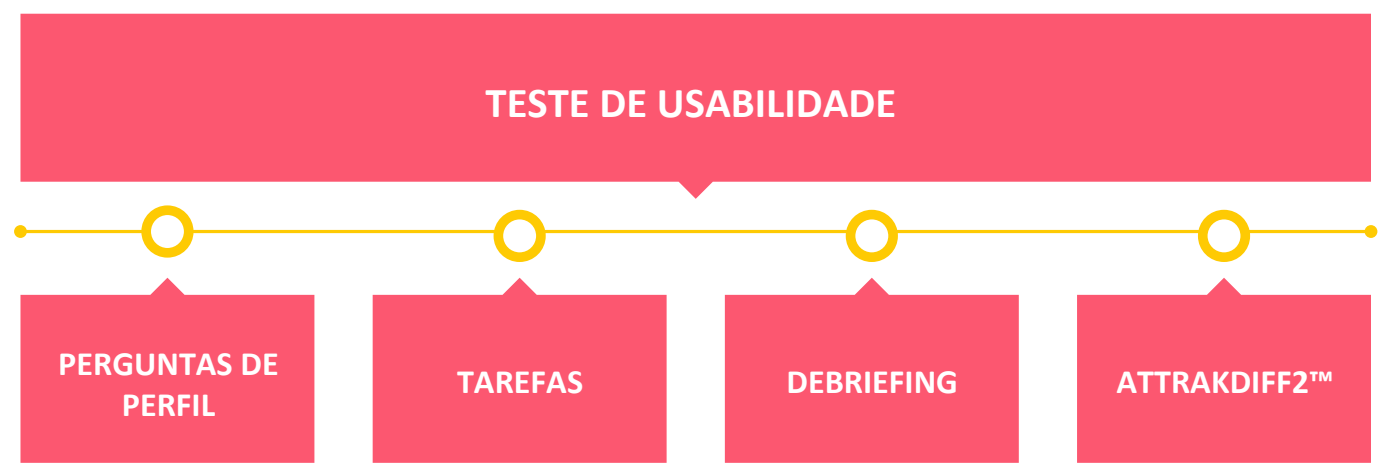

Figura 6.14 - Etapas da fase da pesquisa descritiva. Fonte: Elaborado pela autora.

\subsection{5.}

\section{Teste em laboratório versus teste em campo}

Para entender o comportamento do usuário é importante observá-lo no seu ambiente real de uso (BAXTER; COURAGE; CAINE, 2015). Ao observarmos os usuários em seu ambiente, podemos capturar informações que afetam o uso de um produto - incluindo interrupções e distrações — que não podem ser capturados ou replicados em um ambiente de laboratório. Coletam-se dados ricos e pormenorizados, permitindo obter-se uma visão holística do processo. Trata-se de uma investigação da realidade dos usuários, e não de suposições. O resultado é tornar explícitos os aspectos e os processos implícitos do ambiente do usuário (BARBOSA; SILVA, 2010).

Os testes em laboratório tentam descobrir a ação e a conduta de usuários em condições cuidadosamente dispostas e controladas. Porém, alguns aspectos importantes não podem ser observados pelas condições idealizadas no laboratório (MARCONI; LAKATOS, 2003). Os testes de campo são aqueles realizados no ambiente real de uso; eles permitem alcançar diferentes objetivos entre eles (BAXTER; COURAGE; CAINE, 2015):

1) desafiar ou verificar suposições que as partes interessadas tenham sobre os usuários, suas tarefas e seu ambiente; 
2) identificar uma falta de correspondência entre a forma como o usuário trabalha e pensa e a forma como as ferramentas e os procedimentos lhes obrigam a trabalhar;

3) entender os objetivos dos usuários;

4) definir uma hierarquia de tarefas;

5) coletar artefatos (i.e., objetos ou itens que os usuários utilizam para completar suas tarefas, ou que resultam de suas tarefas); e

6) verificar se os usuários correspondem aos perfis de usuários traçados inicialmente.

O ambiente de uso faz parte da composição da medida de usabilidade, ao considerar dispositivos móveis, a contextualização de uso de um produto é de suma importância, em razão de sua natureza portátil. Porém, é quase impossível prever todas as situações e reproduzi-las em um laboratório (DUH; TAN; CHEN, 2006). Por estes motivos, os métodos para o desenvolvimento de testes de usabilidade devem ser reformulados. Estes têm sido tradicionalmente conduzidos em um contexto fixo ou seja, com os usuários geralmente usando um computador desktop/laptop, para realizar tarefas (JOHNSON, PETER, 1998). O uso difundido de dispositivos móveis altera essa suposição. Os meios tradicionais de entrevistas de usuários ou testes de usabilidade em um ambiente de laboratório podem não revelar informações sobre as atividades dos usuários e a mobilidade em sua vida real (SUN; MAY, 2013).

Conceitos, metodologias e abordagens estabelecidas no HCI estão sendo desafiados pelo crescente foco em aplicativos móveis. (SUN; MAY, 2013) O contexto torna-se uma consideração crítica na obtenção de informações sobre os requisitos dos usuários. O método de pesquisa contextual (CI) pode tornar a observação do usuário, ao executar tarefas mais realista, levando-o a explorar a versatilidade dos padrões e do ambiente de uso (VÄÄNÄNEN-VAINIOMATTILA; RUUSKA, 1998).

Um estudo realizado por Duh, Tan e Chen, (2006), revelou que em testes realizados em campo foram descobertos um maior número de problemas críticos ${ }^{13}$ de usabilidade e outros que foram somente observáveis em campo. Este estudo

\footnotetext{
${ }^{13}$ Problemas críticos: previnem o cumprimento da tarefa e são recorrentes nos testes com todos os usuários (MOLICH, 2007)
} 
tinha como objetivo avaliar a eficácia dos testes de laboratório, principalmente no que tange os dispositivos móveis. Foi levado em conta a natureza portátil desses dispositivos e consequentemente a dificuldade de reproduzir o ambiente de uso e as diversas situações de uso em um laboratório.

Os testes de campo são vantajosos pois é possível observar o usuário interagindo com o produto em seu ambiente real de uso (BARNUM, 2011; RUBIN; CHISNELL, 2008). Para o caso dos testes com smartphones o campo pode ser a casa do usuário, seu trabalho ou o vagão do metrô. Nessas situações reais pode compreender-se qual o impacto de distrações e ruídos que "competem" pela atenção do usuário; assim como medir a influência da luz, ou a falta dela, por exemplo.

Embora a pesquisa contextual possa ajudar os desenvolvedores a garantir uma compreensão realista sobre os fatores que afetem o comportamento do usuário em movimento, a realização de observações e inquéritos não invasivos continua sendo um desafio (CHAN, SUSY S.; FANG, 2003). Conduzir testes em campo pode trazer uma série de desvantagens, tais como: a falta de controle sobre o ambiente, a logística, a falta de privacidade para testes como o Think Aloud Protocol, pois demandam que o usuário fale ao executar as tarefas solicitadas, entre outras exigências ou expectativas de comportamento (BARNUM, 2011; RUBIN; CHISNELL, 2008). Como o objetivo dessa pesquisa é medir a experiência do usuário ao comprar peças de roupas em sítios de vestuário feminino, tanto em desktop quanto em smartphones, essas situações adversas devem ser consideradas ao projetar-se uma interface. Assim sendo, as desvantagens mencionadas contribuem para o objetivo dessa pesquisa e seus testes de usabilidade foram conduzidos em campo, não em laboratório.

\section{2.}

\section{Questionário AttrakDiff2 ${ }^{\mathrm{TM}}$}

Como descrito no capítulo 2, desta dissertação, pode categorizar-se a qualidade de produtos em pragmática e hedônica. A primeira refere-se a um julgamento do potencial de um produto para suportar objetivos de 'fazer', comprar uma blusa, por exemplo. A qualidade hedônica é um julgamento em relação ao potencial de um produto ou serviço para sustentar o prazer no uso e 
propriedade, ou seja, diz respeito aos objetivos de 'ser', como ser admirado e estimulado (HASSENZAHL et al., 2015).

A interação humano-computador pode ser definida como uma disciplina que diz respeito ao design, avaliação e implementação de sistemas (produtos) interativos para uso do homem. (HASSENZAHL, 2006 apud Hewett et Al.) Avaliar um produto pressupõe estabelecer uma definição de sua qualidade, se é bom ou ruim. A usabilidade é uma definição amplamente aceita (HASSENZAHL, 2006), a ISO-9241-11 a define como: "medida na qual um produto pode ser usado por usuários específicos com eficácia, eficiência e satisfação em um contexto específico de uso". Por sua vez a eficácia é definida como a "acurácia e completude com as quais usuários alcançam objetivos específicos", "eficiência define-se como recursos gastos em relação à acurácia e à abrangência com as quais os usuários atingem objetivos" e satisfação é a "ausência do desconforto e atitudes positivas para com o uso de um produto". Apesar de muito difundida, essa definição concentra-se apenas em tarefas, objetivos e o processamento cognitivo de informações.

Desta perspectiva, as abordagens baseadas apenas na usabilidade são limitadas uma vez que tendem a ter uma visão dos produtos como ferramentas com as quais os usuários efetuam tarefas. Contudo, produtos não são meramente ferramentas: alguns deles podem ser considerados como objetos vivos com os quais as pessoas têm relacionamentos. Os produtos podem tornar as pessoas felizes ou irritadas, orgulhosas ou envergonhadas, seguras ou ansiosas. (MARZANO, 1998 apud JORDAN, 2000)

As pessoas têm personalidades, além de expectativas, medos, sonhos e aspirações e estes afetam a maneira como interagem com os produtos. A literatura e os estudos sobre a interação humano-computador tratam o usuário principalmente como um processador físico e cognitivo, estão preocupados somente com os níveis de eficácia, eficiência e satisfação com os quais concluem tarefas, não abordam suas respostas emocionais aos produtos que estão usando e experimentando. A satisfação, definida pelo campo de estudos da usabilidade, é tradicionalmente operacionalizada a limitar-se para evitar o desconforto físico e cognitivo (JORDAN, 2000).

A ISO-9241 (ISO 9241-210, 2010) define a experiência do usuário, ou UX, como as percepções e respostas dos usuários resultantes do uso e/ou antecipação 
do uso de um produto, sistema ou serviço. A UX é o resultado dessa interação, com um sistema que tem um começo e um fim, produzindo memórias dessa experiência (ROTO et al., 2010). Ressalte-se que o processo de compra nem sempre é racional, pode envolver questões subjetivas culturais e emocionais (JEDDI et al., 2013). Para medir a UX foi escolhida a ferramenta de avaliação AttrakDiff2 ${ }^{\mathrm{TM}}$. Trata-se de um questionário desenvolvido por Hassenzahl; Burmester; Koller, 2003, especialmente para abordar as percepções do impacto emocional de um usuário, causadas pela interação com um produto. Este questionário assume as duas categorias de percepção de um produto mencionadas acima: hedônica e pragmática.

AttrakDiff2 $^{\mathrm{TM}}$ é um questionário de diferencial semântico composto de 28 itens (Anexo 1). Sete itens capturam a qualidade pragmática (PQ), quatorze itens capturam a qualidade hedônica que é dividida em: identidade (HQ_I) e estímulo (HQ_S). A qualidade hedônica-identidade diz respeito a aspectos que possam auxiliar na maneira como um indivíduo quer ser percebido por outros, comunicando a identidade desejada. A qualidade hedônica-estímulo de um produto dá suporte ao desenvolvimento pessoal do usuário, ou seja, à melhoria do seu conhecimento e das suas habilidades. Os produtos podem dar suporte a esse desenvolvimento, produzindo um efeito estimulante. Funcionalidades inovadoras, interessantes e estimulantes, conteúdo, interações - e estilos de apresentação podem aumentar a atenção, diminuir os problemas de motivação ou simplificar a busca de novas soluções para os problemas existentes e, indiretamente, auxiliar na estimulação da conclusão da tarefa. Sete itens capturam o apelo (ATT) (HASSENZAHL et al., 2015; HASSENZAHL; BURMESTER; KOLLER, 2003a). Utiliza-se uma escala tipo Likert de 7 pontos para avaliar as impressões causadas pela interação do usuário com o produto.

Razões para usar-se AttrakDiff2 ${ }^{\mathrm{TM}}$ :

- AttrakDiff2 ${ }^{\mathrm{TM}}$ está disponível gratuitamente;

- AttrakDiff2 ${ }^{\text {TM }}$ é curto e fácil de administrar, e a escala verbal é fácil de entender;

- AttrakDiff2 ${ }^{\mathrm{TM}}$ é fundamentado com pesquisa e validação estatística; e

- AttrakDiff2тM tem um histórico de aplicações bem sucedidas (HARTSON; PYLA, 2012). 
Por fim, no que refere-se a métodos e técnicas sendo aplicados especificamente para análise de UX, o AttrakDiff2 ${ }^{\mathrm{TM}}$ está entre os mais citados (PADOVANI; SCHLEMMER; SCARIOT, 2012).

O questionário foi desenvolvido em alemão e possui uma versão oficial em inglês. Existem versões traduzidas para o Português, como o utilizado por Lira e Tavares (2015) para medir a experiência do usuário ao interagir com um instrumento de visualização de bacias hidrográficas. O Attrakdiff2 ${ }^{\mathrm{TM}}$ também foi traduzido para o português e aplicado por Cardoso (2013) para medir a experiência do usuário durante as etapas de desenvolvimento de um aplicativo social móvel (Vide Anexo 2 para verficição dos dois exemplos).

Alguns problemas de tradução foram encontrados nas versões existentes em português, então o Attrakdiff2 ${ }^{\mathrm{TM}}$ foi traduzido do inglês pela autora e validado por dois especialistas em tradução português-inglês inglês-português. Uma vez validadas, foram geradas 3 versões do questionário e foram submetidas a um painel com pesquisadores do LEUI (Laboratório de Ergonomia e Usabilidade de Interfaces - PUC-Rio), para a definição da versão final (Apêndice 2).

\section{É importante entender a experiência do usuário}

Em muitos dos primeiros trabalhos na indústria, a usabilidade era operacionalizada primariamente relacionada à performance do usuário (eficiência e eficácia), sendo considerada a questão primordial para os muitos problemas que eram vivenciados por usuários de sistemas comerciais. Porém, à medida que o uso de produtos complexos e o uso da World Wide Web popularizaram-se, houve um crescimento da importância da conscientização das reações subjetivas e a experiência emocional do usuário. Isso levou alguns autores a considerar a usabilidade como sendo restrita a "facilidade de uso" e relegar seu papel ao "fator de higiene", por exemplo: usabilidade “...é o termômetro que determina o nível de 'higiene' de um produto. Os usuários, atualmente, não enxergam o conceito de 'facilidade de uso' de um produto e não irão valorizar o fato de um produto ou serviço ter uma boa usabilidade.” (HELLMAN; RÖNKKÖ, 2008). Similarmente, (HASSENZAHL; DIEFENBACH; GÖRITZ, 2010) diferenciam a facilidade de uso como uma “qualidade pragmática como sendo um 'fator de higiene', possibilitando a realização das necessidades, retirando barreiras, mas não é uma fonte de experiências positivas, por si só", da "qualidade hedônica, esta sendo um 
'motivador, capturando a habilidade percebida de um produto em criar experiências positivas por suprir necessidades". A ISO 9241-210:2010 "Design centrado no humano para sistemas interativos" define a experiência do usuário como as percepções e respostas dos usuários resultantes do uso e/ou antecipação do uso de um produto, sistema ou serviço. A experiência do usuário concentra-se na experiência de um indivíduo, contrastando com a visão de eficácia, eficiência e satisfação, representando uma coletânea de respostas de um grupo de usuários. (BEVAN; CARTER; HARKER, 2015).

\section{3.}

\section{Execução do questionário Attrakdiff2 ${ }^{\mathrm{TM}}$}

O questionário AttrakDiff2 ${ }^{\mathrm{TM}}$ era a última etapa do teste de usabilidade. Após a realização das tarefas e do debriefing, as voluntárias eram solicitadas a responderem o questionário. Primeiro eram instruídas a lerem as instruções, caso houvessem dúvidas, estas eram esclarecidas pela autora desta dissertação. Como o intuito de ser mais eficiente, as voluntárias eram solicitadas a responderem o questionário sem analisar nem pensar muito a respeito das perguntas.

\section{4 .}

\section{Análise de tarefas}

O processo de descrever as tarefas e seus relacionamentos é chamado de análise de tarefas e é usado para nortear um projeto e construir modelos que antecipam o desempenho da tarefa do usuário (HARTSON; PYLA, 2012). A análise de tarefas refere-se a uma série de técnicas que envolvem o uso de questionários ou entrevistas abertas para desenvolver uma compreensão detalhada de como as pessoas realizam tarefas específicas (COOPER et al., 2014).

A análise de tarefas decompõe as tarefas executadas advindas da interação com um produto em uma série de etapas. As técnicas podem ser usadas para fazer previsões sobre o quão difícil ou fácil são as tarefas e quanto esforço provavelmente será exigido. O resultado é uma lista das etapas físicas que o usuário deve executar para realizar uma tarefa específica. Análises de tarefas mais complexas também podem levar em conta os passos cognitivos envolvidos em 
uma tarefa. A medida básica da complexidade da tarefa é a quantidade de etapas necessárias para concluí-la, e as tarefas mais simples envolvem menos etapas.

Esta forma de estudo diz respeito aos seguintes itens:

a) Por que o usuário está executando a tarefa (ou seja, a meta subjacente);

b) A frequência e importância da tarefa;

c) Gatilhos - o que inicia ou solicita a execução da tarefa;

d) Dependências - o que deve estar em vigor para realizar a tarefa, bem como o que depende da conclusão da tarefa;

e) Pessoas envolvidas e seus papéis e responsabilidades;

f) Ações específicas que são executadas;

g) Decisões tomadas;

h) Informações que são usadas para apoiar as decisões;

i) O que dá errado - erros e casos de exceção; e

j) Como os erros e as exceções são corrigidos (COOPER et al., 2014).

Em IHC (interação humano-computador), a análise de tarefas pode ser utilizada para: analisar a situação atual de um sistema, redesenhar o seu projeto ou avaliar o resultado de uma intervenção. Quando visa a avaliar um sistema computacional existente, a análise de tarefas pode ser bem concreta, descrevendo o comportamento de forma pormenorizada (BARBOSA; SILVA, 2010). Segundo, Preece, Rogers e Sharp (2015) a análise de tarefas é usada principalmente para investigar uma situação existente, não para visualizar novos produtos. É usada para analisar o raciocínio subjacente e o propósito do que as pessoas estão fazendo: o que eles estão tentando alcançar, por que eles estão tentando alcançar, e como? Para esta pesquisa a análise de tarefas será utilizada para avaliar um sistema já existente.

Diaper (2008) ressalta que este tipo de análise é potencialmente o método mais poderoso de avaliação para quem trabalha com IHC e está focada na performance do trabalho. Performance no âmbito da análise de tarefa está relacionado ao trabalho com o objetivo de atingir metas. Jordan (2001) aponta as desvantagens da técnica, com exceção das análises de tarefas que analisam a consistência e a compatibilidade, a maioria pressupõe um desempenho "de especialista" com o sistema por parte do usuário. As regras listadas refletirão a maneira mais eficiente de executar uma tarefa. Assim como há problemas com a 
simples contagem do número de etapas, pois se não considera as suas intrínsecas complexidade, podendo afetar a usabilidade.

A análise de tarefas é uma maneira crítica de entender como os usuários fazem atualmente alguma coisa, bem como identificar obstáculos e oportunidades de melhoria. A maneira com a qual as pessoas executam tarefas usualmente tem pouca semelhança com a forma como elas gostariam de fazê-las ou como elas poderiam ser mais eficazes (COOPER et al., 2014). O modo por meio do qual os projetistas percebem a interface e sua relação com o usuário muitas vezes divergem (NIELSEN, 2008).

\subsection{1.}

\section{Análise de Tarefas Hierárquica}

A Análise de tarefas hierárquicas, HTA, (sigla em inglês de Hierarchical Task Analysis) trata-se de quebrar uma tarefa em sub-tarefas e, em seguida, em sub-sub-tarefas e assim por diante, como na Figura 6.15. Estas são então agrupadas como planos que especificam como as tarefas podem ser realizadas em uma situação real. A HTA concentra-se nas ações físicas e observáveis que são realizadas, e inclui observar as ações que não estão relacionadas ao software ou a um produto interativo. O ponto de partida é uma meta do usuário (PREECE; ROGERS; SHARP, 2015).
0. Para comprar um DVD
1. localizar DVD
2. Adicionar DVD ao carrinho de compras
3. introduzir detalhes de pagamento
4. endereço completo
5. confirmar a ordem

Plano 0: Se é um usuário regular execute os passos: 1-2-5. Se é um novo usuário execute os passos: 1-2-3-4-5.

Figura 6.15 Uma HTA para comprar um DVD (PREECE; ROGERS; SHARP, 2015: p.985) 
Uma expressão alternativa de uma HTA é uma notação gráfica, a Figura 6.16 mostra a versão gráfica da HTA, as sub-tarefas são representadas por caixas identificadas por números.

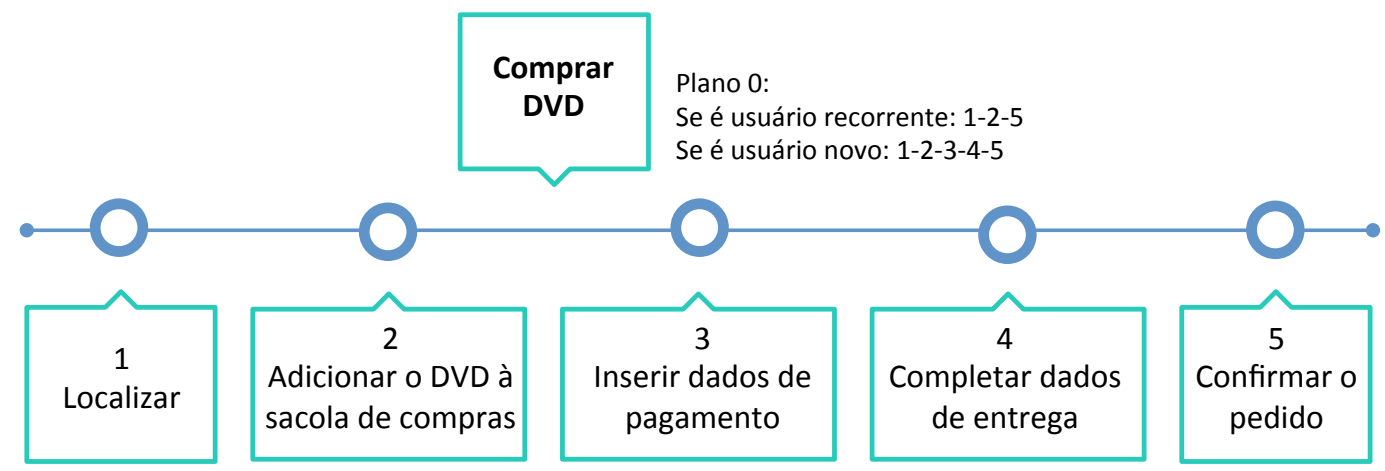

Figura 6.16 - Representação gráfica de uma análise de tarefas para comprar um DVD. Fonte: Elaborado pela autora baseado em (PREECE; ROGERS; SHARP, 2015, p. 986).

\subsection{2.}

\section{Execução da análise de tarefa}

Uma vez que os testes de usabilidade foram concluídos, as tarefas foram decompostas e analisadas. Normalmente, elas são incorporadas em um fluxograma que comunica as relações entre as ações e, muitas vezes, as relações entre as pessoas e os processos (COOPER et al., 2014). As informações obtidas a partir da análise de tarefas estabelecem um fundamento de práticas utilizadas nas quais pode construir-se novos requisitos ou projetar novas tarefas.

Após o término dos testes de usabilidade, todos os vídeos foram analisados e as tarefas executadas por cada voluntária foram decompostas em passos, este processo permitiu quantificar de passos necessários para cada uma das voluntárias atingir os objetivos das tarefas do teste de usabilidade. As Figuras 6.17 à 6.24 ilustram o número de caminhos possíveis e com o menor número de etapas necessárias para o cumprimento das tarefas. As Figuras 6.17 à 6.20 representam as tarefas realizadas em desktop/laptop e as Figuras 6.21 à 6.24 aquelas realizadas em smartphones. Estas figuras servirão de base para avaliar o desempenho das voluntárias ao executarem as tarefas do teste de usabilidade e serão classificadas como: cumpriu com facilidade, cumpriu ou cumpriu com dificuldade.

A tarefa 1 poderia ser executada de duas formas em um laptop/desktop (Figura 6.17); por meio do caminho A ou B, ambos opções levariam 5 passos para serem cumpridas. 


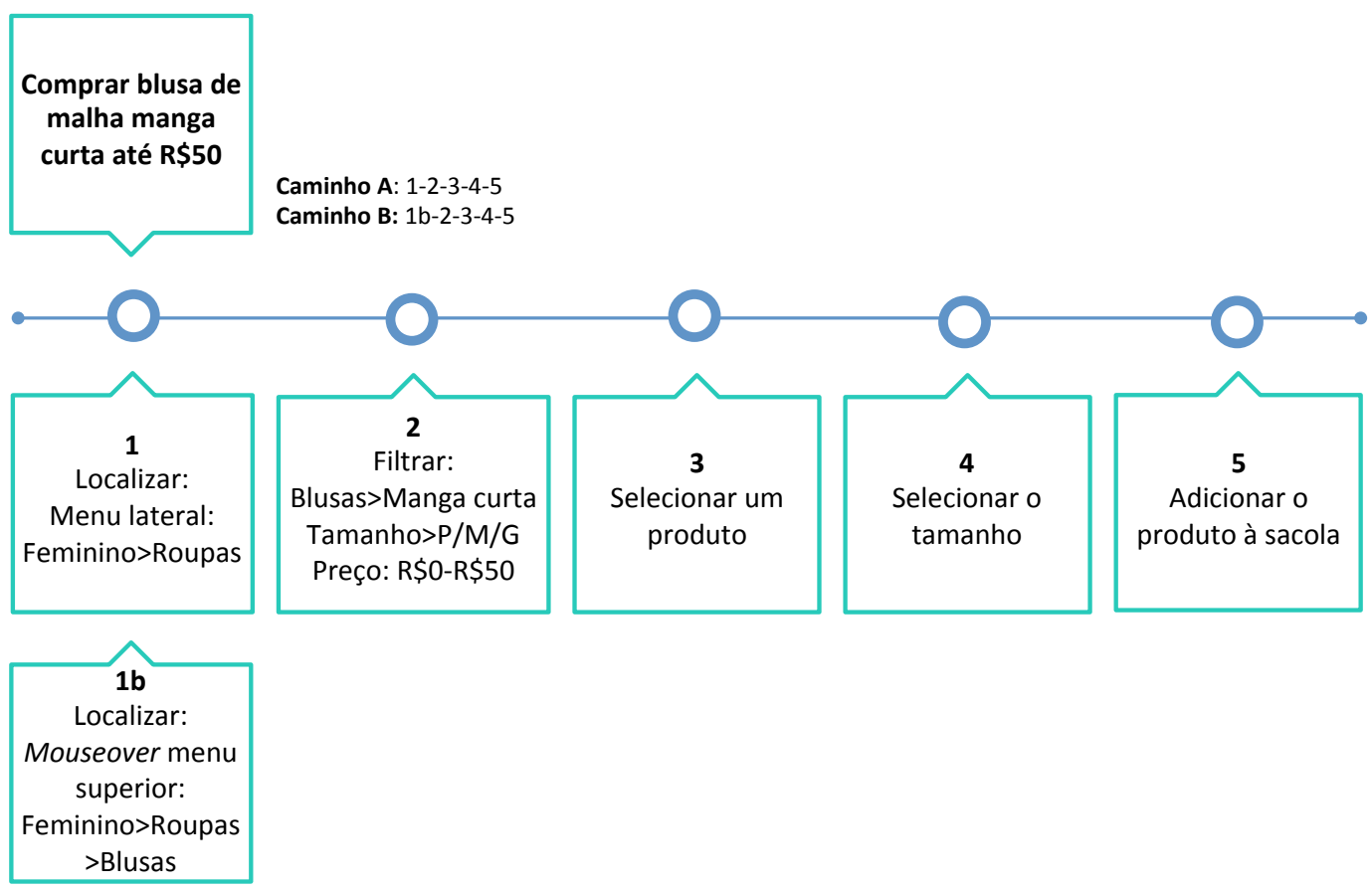

Figura 6.17 - Análise da Tarefa 1 no desktop/laptop. Fonte: Elaborado pela autora.

Há duas formas para executar a tarefa 2 quando executada de um desktop/laptop, por meio dos caminhos A e B, como ilustrado na Figura 6.18. E como na tarefa 1 , os dois caminhos possíveis eram compostos de 5 passos cada um.

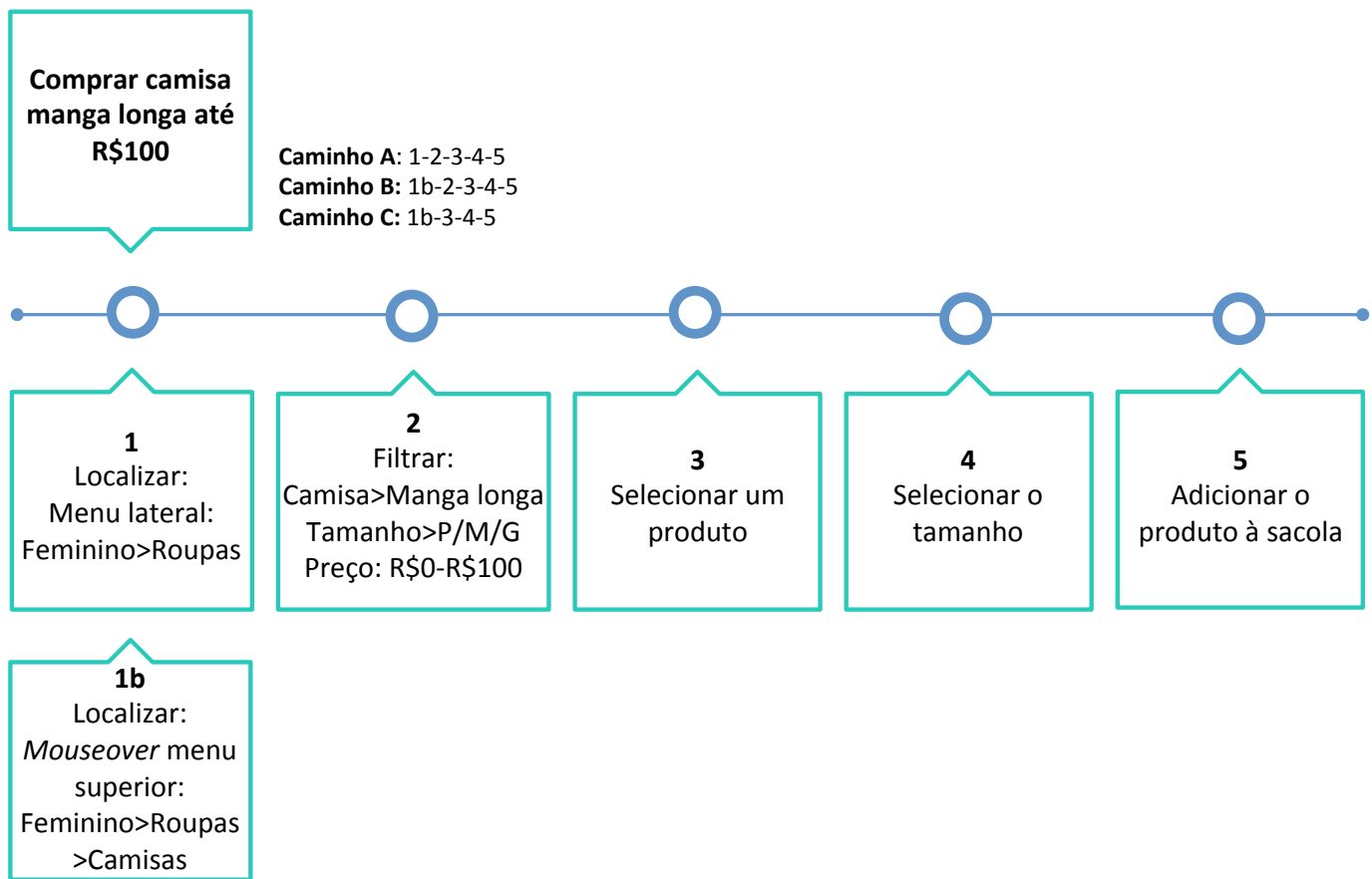

Figura 6.18 - Análise da Tarefa 2 no desktop/laptop. Fonte: Elaborado pela autora. 
A tarefa 3 executada de um desktop/laptop pode ser feita por 3 caminhos possíveis (Figura 6.19) Os caminhos A e B consistiam de 3 passos cada um e o caminho $\mathrm{C}$ de 4.

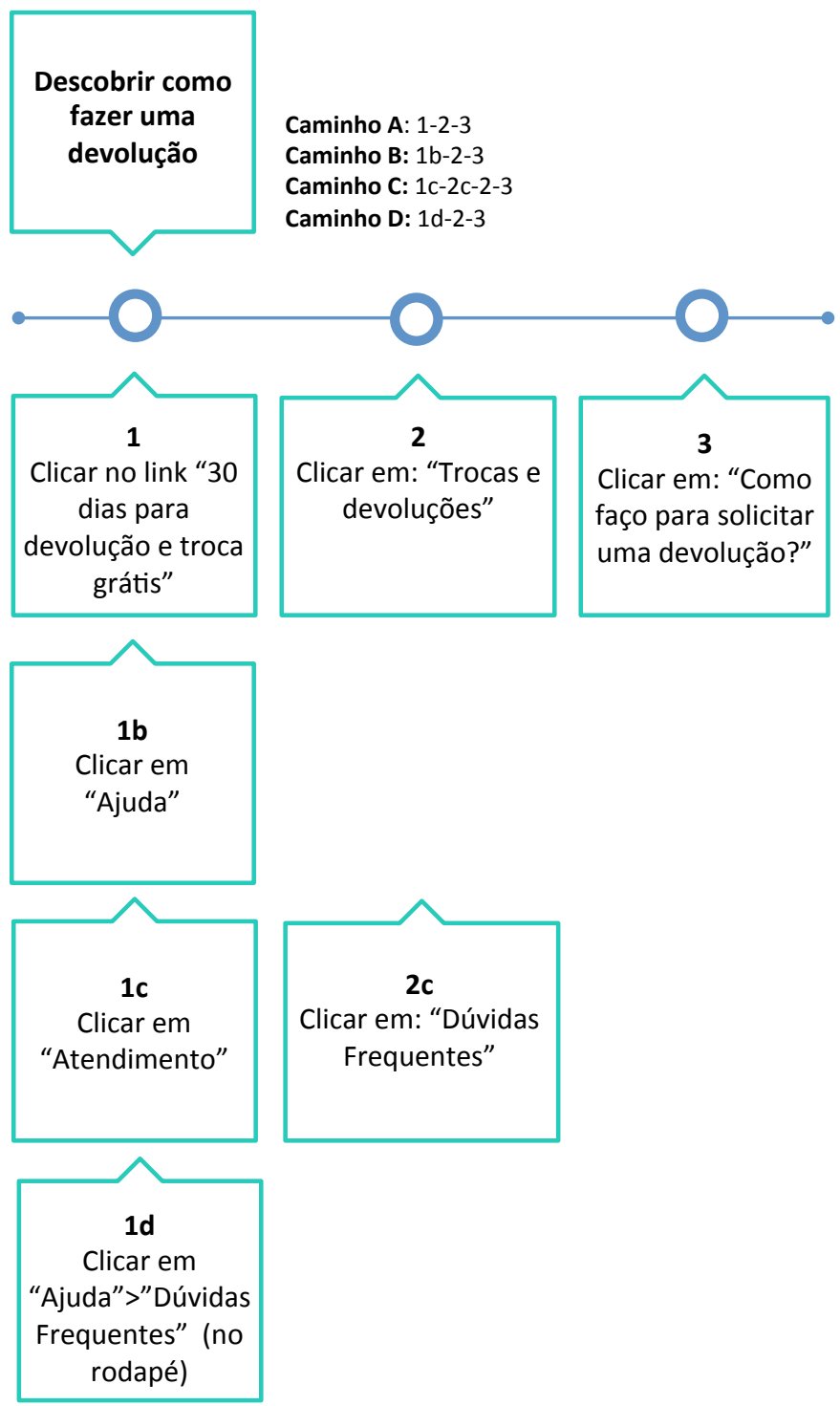

Figura 6.19 - Análise da Tarefa 3 no desktop/laptop. Fonte: Elaborado pela autora.

A última tarefa executada de um desktop/laptop era possível ser executada por 3 caminhos assim como a tarefa 3 (Figura 6.20). Os caminhos A e B consistiam de 3 passos e o caminho $\mathrm{C}$ de 4 passos. 


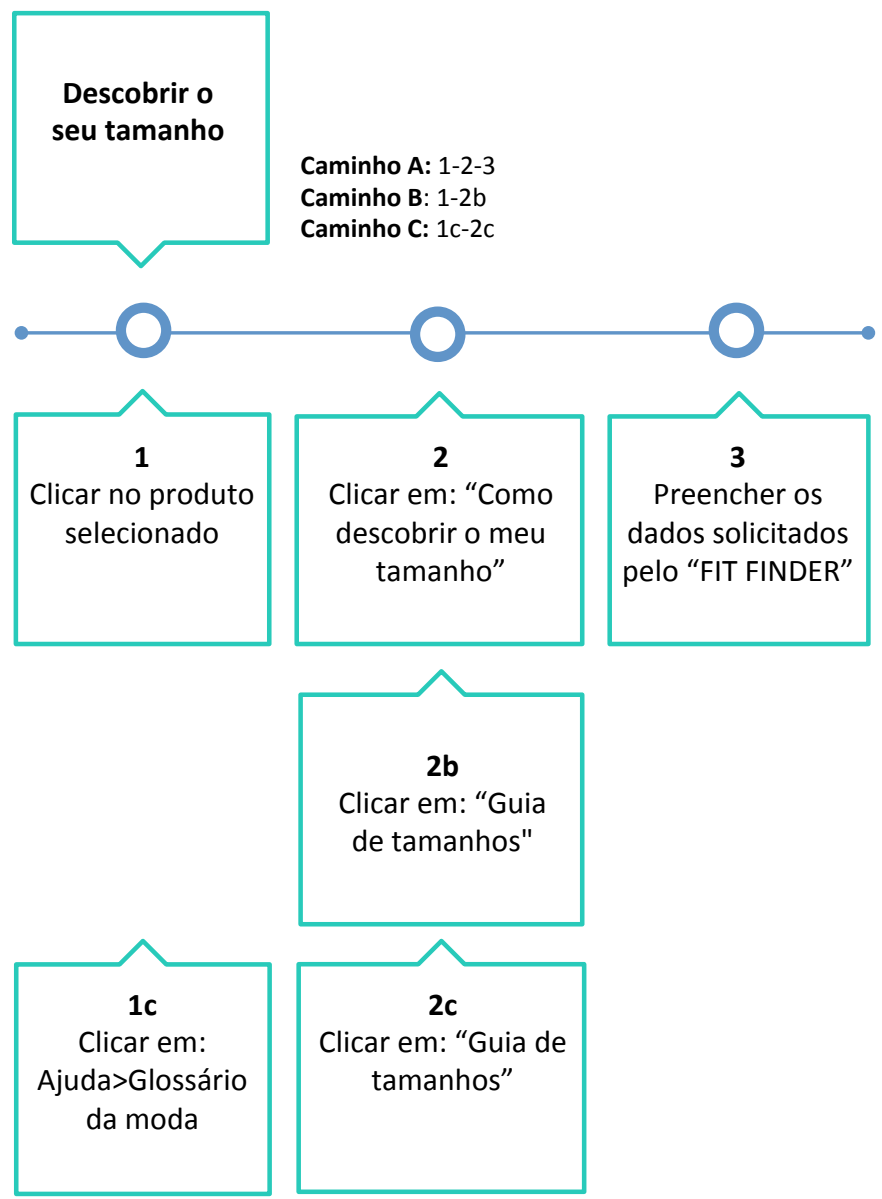

Figura 6.20 - Análise da Tarefa 4 no desktop/laptop. Fonte: Elaborado pela autora.

A primeira tarefa, quando executada de um smartphone, poderia ser cumprida tomando-se dois caminhos, o primeiro, o caminho A, era composto por 5 passos (Figura 6.21). O caminho B consistia de 6 passos. A tarefa 1 quando executada de um smartphone, demandava um pouco mais de esforço da usuária do que quando executada de um desktop/laptop.

A tarefa 2 tinha dois caminhos para ser executada de um smartphone (Figura 6.22). O caminho A tinha 5 passos e o caminho 6, novamente, as usuárias tinham de executar um passo a mais ao utilizar um smartphone. 


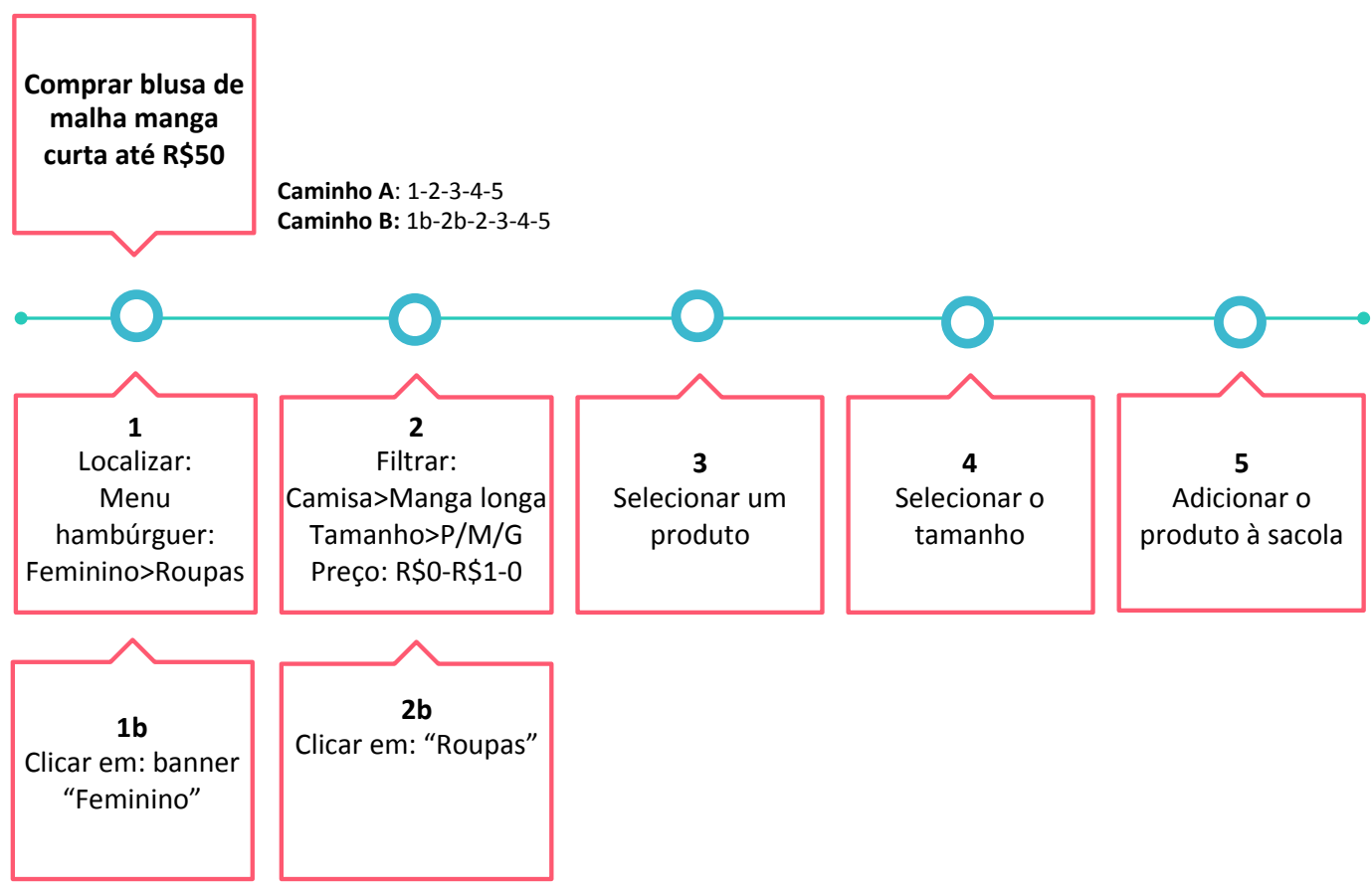

Figura 6.21 - Análise da Tarefa 1 no smartphone. Fonte: Elaborado pela autora.

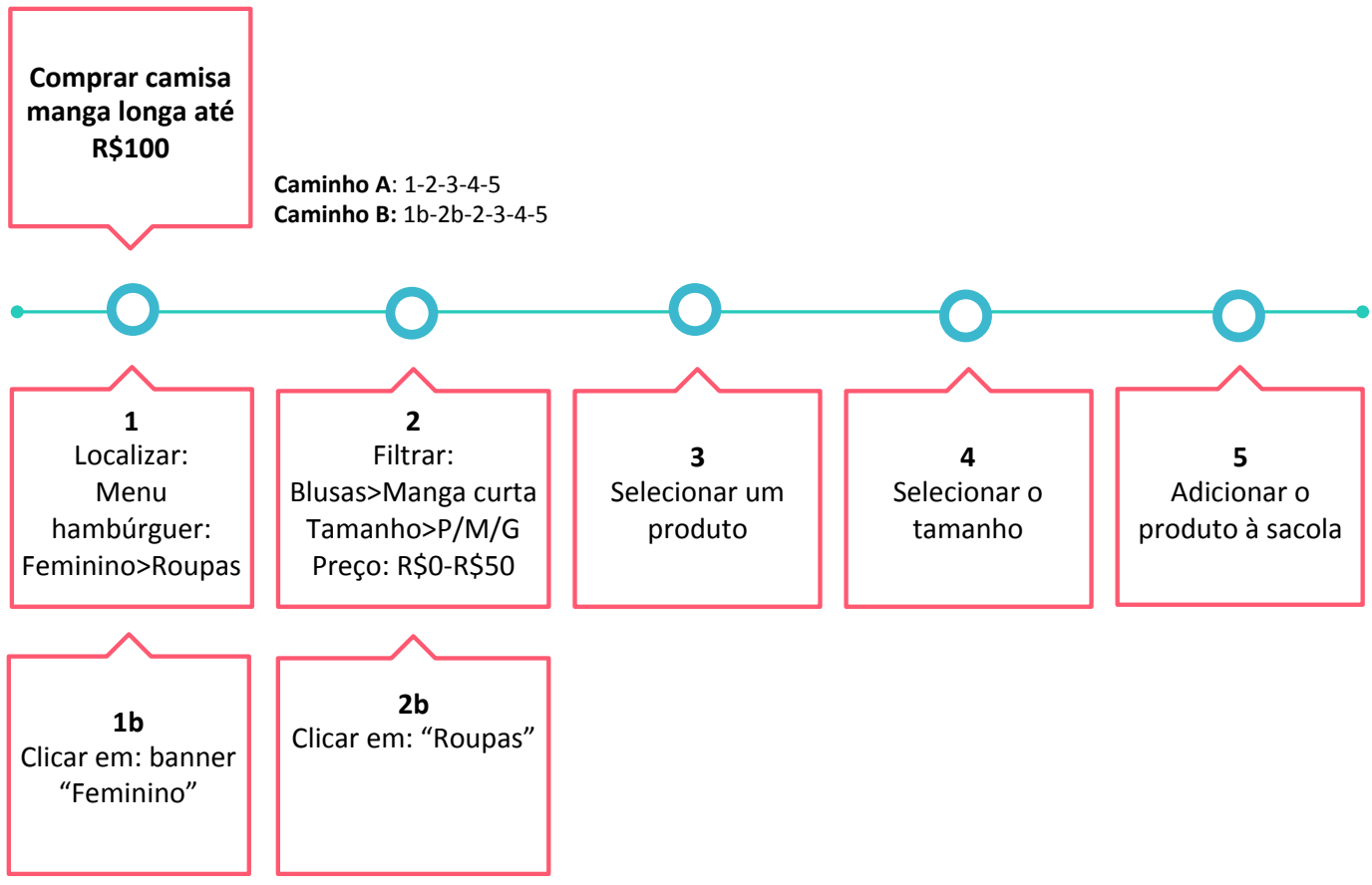

Figura 6.22 - Análise da Tarefa 2 no smartphone. Fonte: Elaborado pela autora.

A tarefa 3 era bem simplificada para ser feita utilizando um smartphone, as usuárias tinham dois caminhos possíveis para seguir, o caminho A poderia ser realizado em somente 2 passos e o caminho B em 3 (Figura 6.23).

Por fim, a tarefa 4 poderia ser realizada por dois caminhos, o A em 2 passos e o B em 3 passos (Figura 6.24). 


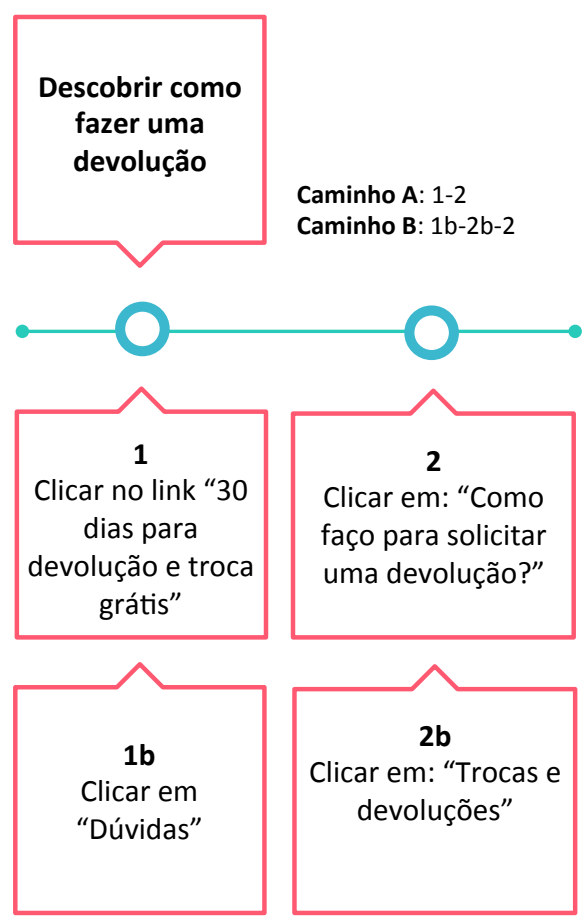

Figura 6.23 - Análise da Tarefa 3 no smartphone. Fonte: Elaborado pela autora.

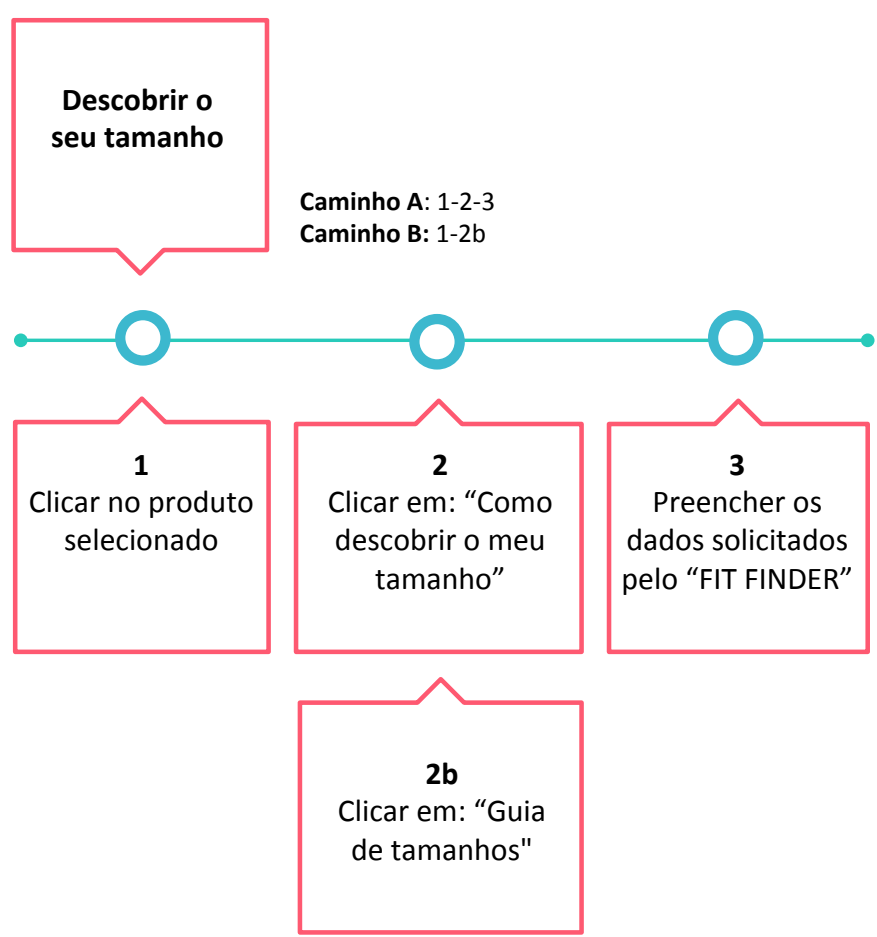

Figura 6.24 - Análise da Tarefa 4 no smartphone. Fonte: Elaborado pela autora. 


\section{5.}

\section{Observações sobre o capítulo 6}

Neste capítulo foram apresentadas as técnicas de pesquisa utilizadas na fase da pesquisa descritiva. Os conceitos por detrás de cada técnica foram expostos assim como os passos de sua execução. No capítulo seguinte, o último, serão apresentados e discutidos os resultados desta fase da pesquisa descritiva. Além disso, serão abordadas as considerações finais, as conclusões e sugestões de desdobramentos futuros. 


\section{Apresentação, análise e discussão dos resultados}

Os capítulos 2, 3 e 4 formaram a base da fundamentação teórica desta pesquisa. O capítulo 2 apresentou os principais conceitos teóricos sobre ergonomia, usabilidade e experiência do usuário que sustentam os argumentos desta dissertação. $\mathrm{O}$ capítulo 3 teve o objetivo de expor o cenário do e-commerce e alguns aspectos ergonômicos. No capítulo 4 termos importantes da moda e do vestuário foram introduzidos e, posteriormente, discutidos, além de serem expostos os números e o panorama do mercado de moda nacional. Os capítulos 5 e 6 apresentam as fases práticas da pesquisa. No capítulo 5 foi discutida a da pesquisa exploratória, as técnicas de pesquisa utilizadas foram expostas e conceituadas e os seus resultados apresentados e discutidos. O capítulo 6 foi elaborado em consequência das descobertas descritas no $5^{\circ}$ capítulo. As técnicas de pesquisa utilizadas no que foi denominada como fase da pesquisa descritiva, foram expostas e conceituadas. Por fim, no capítulo 7 serão apresentados os resultados da pesquisa descritiva, as conclusões e os possíveis desdobramentos futuros desta pesquisa.

\section{1.}

\section{Resultados da pesquisa descritiva}

Nos itens a seguir serão descritos os resultados da fase da pesquisa descritiva divididos em: perguntas de perfil, teste de usabilidade, debriefing, e AttrakDiff2 ${ }^{\text {TM }}$.

\subsection{1.}

\section{Resultados das perguntas de perfil}

Selecionando a amostra utilizada no teste de usabilidade

Deve-se definir a população que realizará o teste de usabilidade. É preciso buscar dados junto às pessoas que estão efetivamente utilizando o sítio avaliado, 
os sistemas e não junto a pessoas que gerenciam suas organizações ou que possuem uma visão estreita sobre o que os usuários realmente fazem. Adquire-se informações completamente díspares, quando se lida com os tomadores de decisão ou investidores, em relação àquelas informações fornecidas pelos usuários reais dos produtos de tecnologia da informação (MANDEL, 1997).

Portanto, é importante ouvir o que as pessoas têm a dizer. Há de levar-se em consideração tudo o que o usuário diz representa sua visão pessoal e preferência individual sobre o produto que está sendo desenhado ou avaliado (MANDEL, 1997).

Para participarem do teste de usabilidade foram recrutadas: mulheres, moradoras do Estado do Rio de Janeiro, com escolaridade mínima superior incompleto (Figura 7.1). Considerou-se que homens e mulheres têm impressões diferentes quanto aos processos de compras em geral (KOTLER; KELLER, 2016; SOLOMON, 2011) e consequentemente, das compras on-line. Elas tendem a ter uma percepção de risco maior do que os homens (BAE; LEE, 2011; PASCUAL-MIGUEL; AGUDOPEREGRINA; CHAPARRO-PELÁEZ, 2015) que pode ser mais acentuada quando adquirem peças de roupas.

A enorme variedade de modelos do vestuário feminino e as modelagens, que geralmente são mais ajustadas ao corpo, contribuem para o surgimento de dúvidas quanto ao ajuste e caimento (Capítulo 4). A impossibilidade de inspecionar o produto completamente antes da compra também é percebido como um fator de risco (Capítulo 4). As mulheres são a maioria dos consumidores de artigos de moda e acessórios (ATLAS, 2017).

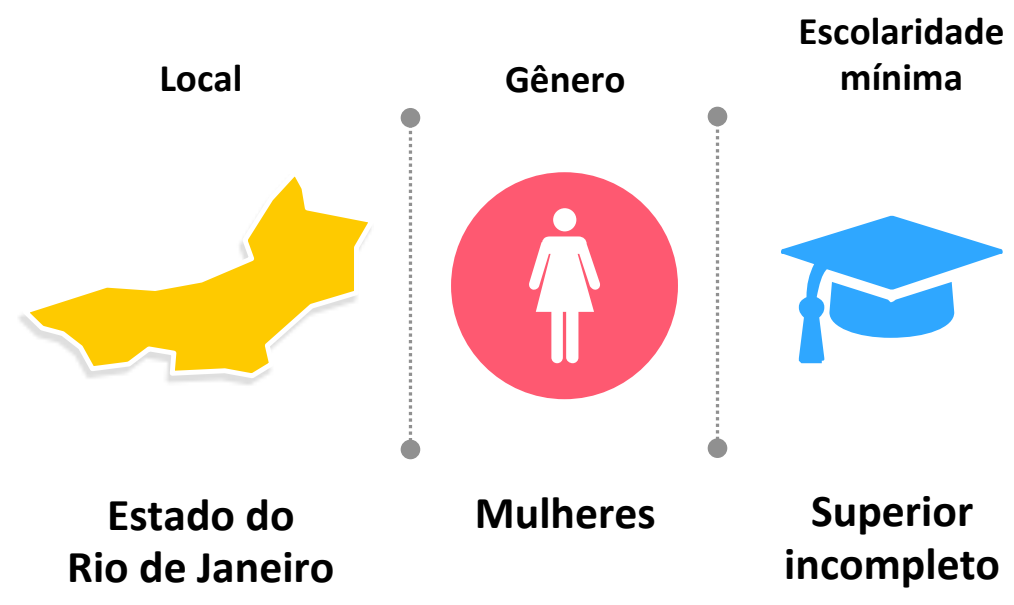

Figura 7.1 - Amostra escolhida para as participantes do teste de usabilidade. Fonte: Elaborado pela autora. 
Ao optar-se pelo critério da escolaridade mínima exigida, considerou-se que, ao ingressar na universidade, o sujeito tenha algum grau de independência financeira para tomar decisões de compra. A localidade: o Estado do Rio de Janeiro, parte do Sudeste do Brasil, região de maior relevância para o e-commerce (responsável por $62,8 \%$ das compras realizadas por meio da internet no $1^{\circ}$ semestre de 2017 (E-BIT, 2017b).

Antes de serem solicitadas à realizarem as tarefas do teste de usabilidade as voluntárias assinaram um Termo de Consentimento e Livre Esclarecimento (Apêndice 3), em seguida responderam à algumas perguntas de perfil, cujos resultados estão descritos a seguir.

Perfil da amostra das voluntárias

O teste de usabilidade teve por objetivo o observar comportamento do usuário quanto à compra on-line. Foram recrutadas 60 voluntárias pela autora desta dissertação, 30 realizaram o teste em um desktop/laptop (Grupo A) e 30 em um smartphone (Grupo B). Suas idades variaram de 19 a 68 anos, média de 33,3, $77 \%$ possuíam um smartphone com o sistema operacional Android e 23\% com o sistema operacional $i O S$ (Figura 7.2). Segundo o critério de recrutamento, todas as participantes deveriam ter ingressado no ensino superior, $30 \%$ das respondentes possuíam pós-graduação completa, tanto no grupo A quanto no grupo B. 17\% das respondentes do grupo A possuíam a escolaridade mínima exigida, superior incompleto, e no grupo $\mathrm{B}$ este número foi maior, 23\% (Tabela 7.1). Foram representadas diversas ocupações, incluindo designers, jornalistas, professores, empresárias e estudantes.
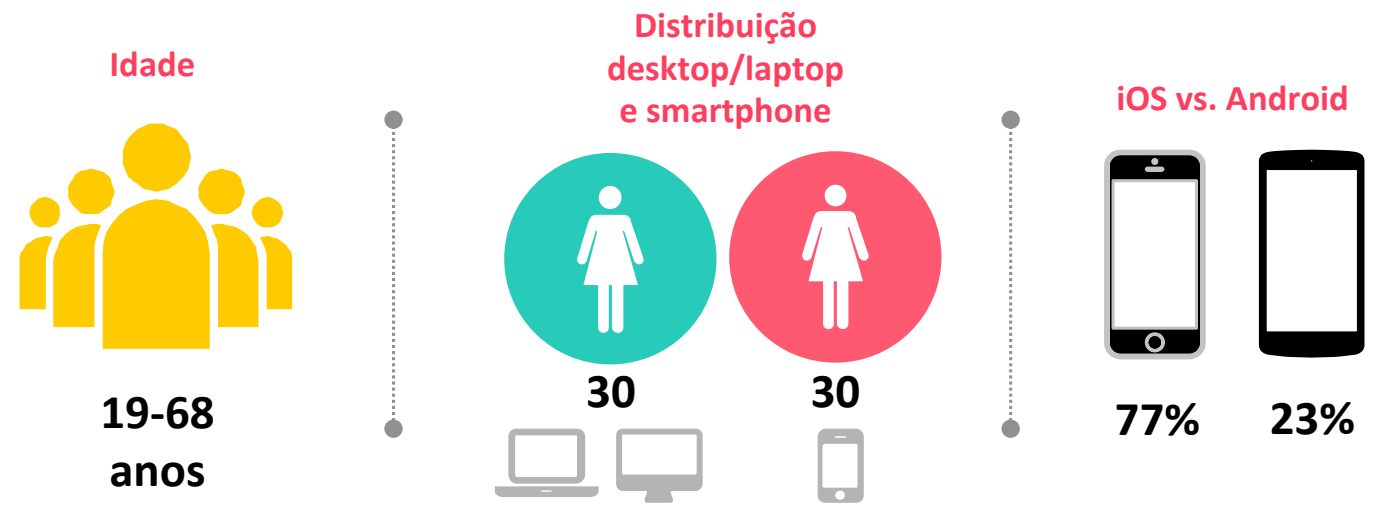

Figura 7.2 - Perfil das voluntárias participantes do teste de usabilidade. Fonte: Elaborado pela autora. 


\begin{tabular}{lcc}
\hline Grau de escolaridade & $\begin{array}{c}\text { Grupo A } \\
\text { (Desktop/ } \\
\text { laptop) }\end{array}$ & $\begin{array}{c}\text { Grupo B } \\
\text { (Smartphone) }\end{array}$ \\
\hline Superior incompleto & $17 \%$ & $23 \%$ \\
Superior completo & $20 \%$ & $23 \%$ \\
Pós-graduação incompleta & - & $10 \%$ \\
Pós-graduação completa & $30 \%$ & $30 \%$ \\
Mestrado incompleto & $23 \%$ & $3 \%$ \\
Mestrado completo & $3 \%$ & $3 \%$ \\
Doutorado incompleto & $3 \%$ & $7 \%$ \\
Doutorado completo & $3 \%$ & - \\
\hline
\end{tabular}

Tabela 7.1 - Escolaridade das voluntárias participantes do teste de usabilidade. Fonte: Elaborado pela autora.

Frequência de compras on-line

A Figura 7.3 mostra a frequência de compras on-line das voluntárias. $37 \%$ do grupo A declararam comprar on-line mais de 2 vezes ao mês, $23 \% 2$ vezes por mês, $17 \%$ uma vez por mês, $13 \%$ uma vez a cada 2 meses e $10 \%$ a cada 4 meses. Das voluntárias do grupo B: 30 \% declararam comprar on-line mais de 2 vezes ao mês, $23 \% 2$ vezes por mês, $23 \%$ uma vez por mês, $13 \%$ uma vez a cada 2 meses, $7 \%$ a cada 4 meses e 3\% a cada 6 meses. Nenhuma das voluntárias declarou não fazer compras on-line.

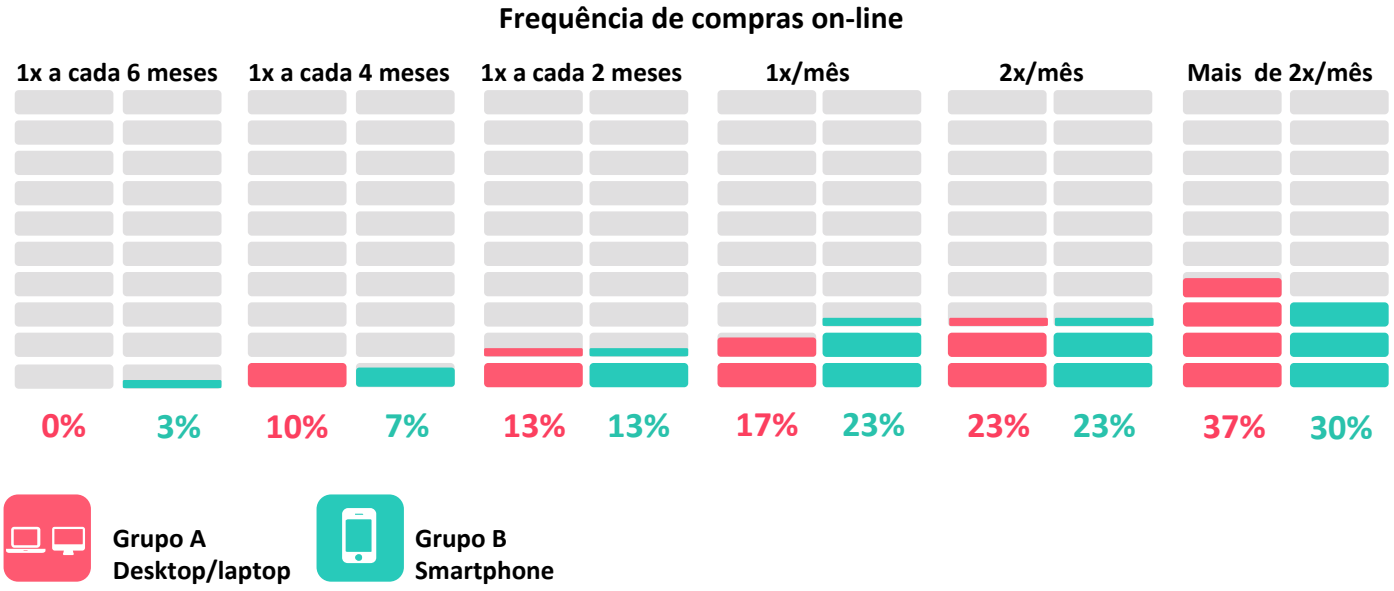

Figura 7.3 - Frequência de compras on-line, desktop/laptop vs. smartphone. Fonte: Elaborado pela autora.

No grupo A, 83\% das voluntárias já haviam comprado roupas por meio da internet e $67 \%$ navegado no sítio dafiti.com. No grupo B, $70 \%$ já haviam comprado roupas por meio da internet e 63\% navegado no sítio dafiti.com (Figura 7.4). 


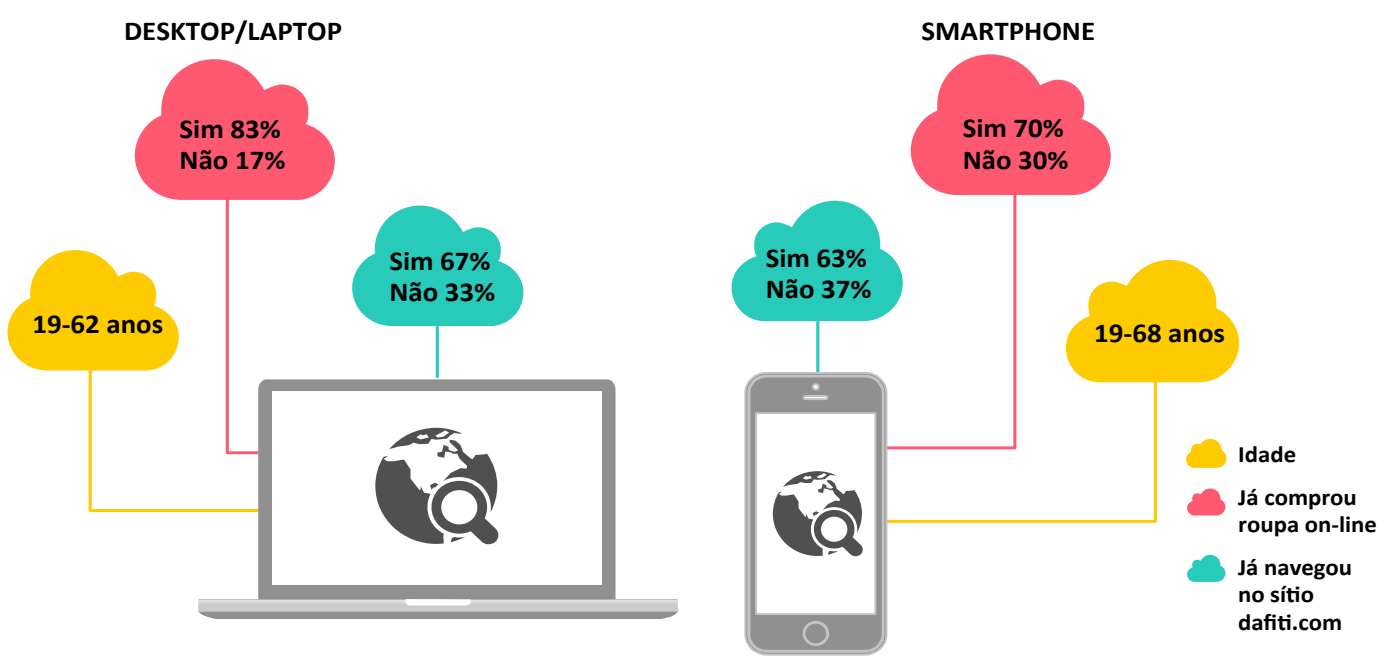

Figura 7.4 - Perfil das voluntárias participantes do teste de usabilidade, desktop/laptop vs. smartphone. Fonte: Elaborado pela autora.

\subsection{2.}

\section{Resultados do teste de usabilidade}

A execução das tarefas do teste de usabilidade resultou em dados tanto quantitativos quanto qualitativos. Entre os resultados quantitativos estão: o cumprimento ou não cumprimento das tarefas, o tempo para cumprir as tarefas, qual tipo de tabela de medidas foi consultada e o número de passos para executar uma tarefa. Durante os testes notou-se que o tempo de cumprimento das tarefas não era um indicativo de facilidade ou dificuldade, a demora para terminar as tarefas muitas vezes era em decorrência de uma navegação mais profunda e criteriosa ao escolher os produtos durante as tarefas 1 e 2 . O tempo médio de navegação em sítios de moda e acessórios é quase 4 vezes maior do que o em sítios das demais categorias (ATLAS, 2017).

Os resultados qualitativos derivaram dos comentários feitos pelas voluntárias durante a execução do teste e das justificativas às perguntas do debrifieng. As voluntárias não eram solicitadas a fazerem comentários mas eram encorajadas caso os julgassem necessários. Algumas verbalizações foram registradas em vídeo e as mais relevantes para os achados da pesquisa serão descritas nos resultados. A seguir serão expostos os resultados quantitativos da fase da pesquisa descritiva.

No grupo A, 27 pessoas cumpriram a tarefa 1, 26 a tarefa 2, 27 a tarefa 3 e 24 a tarefa 4 . A tarefa 4 teve o maior número de desistentes, 5, e uma pessoa não cumpriu 
a tarefa. A tarefa era considerada "não cumprida" quando a voluntária dava a tarefa como finalizada mas não havia atingido o objetivo previsto (Figura 7.5).

No grupo B, como no grupo A, a maioria cumpriu as 4 tarefas. 28 pessoas cumpriram a tarefa 1,27 a tarefa 2, 27 a tarefa 3 e 26 a tarefa 4 . O grupo B teve um número maior de pessoas que não cumpriram a tarefa. Os dois grupos, A e B tiveram números similares e não houve nenhuma grande diferença entre eles.
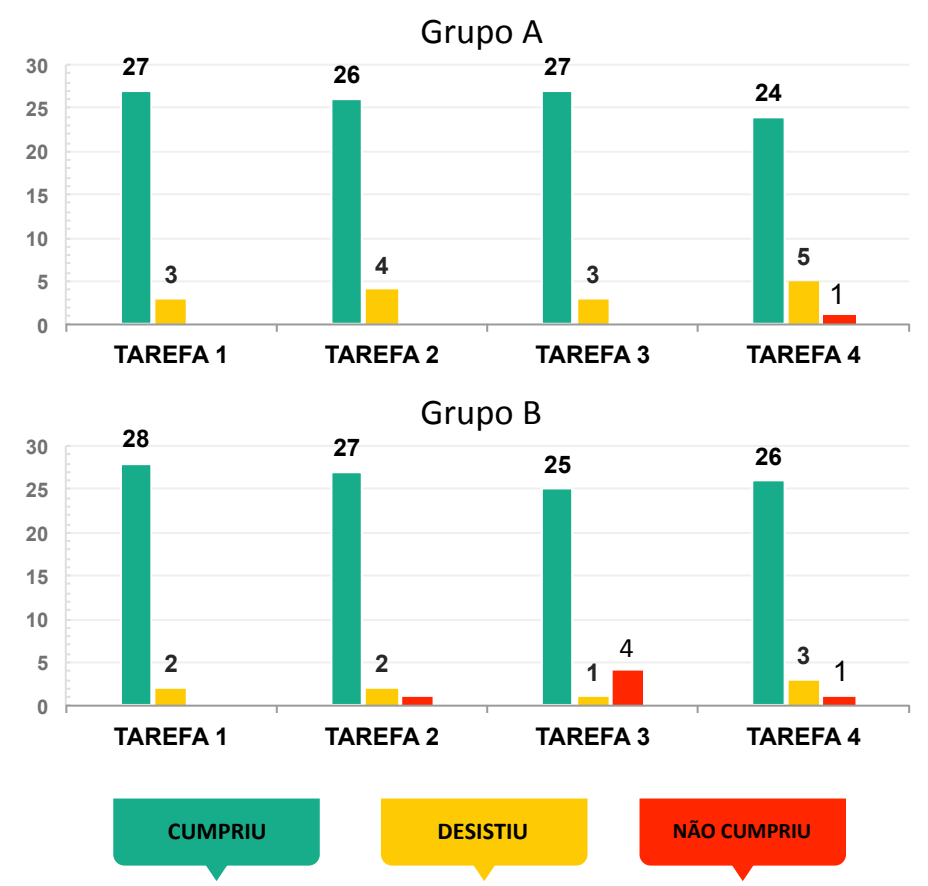

Figura 7.5 - Cumpriu/Não Cumpriu/Desistiu da tarefa no teste de usabilidade. Fonte: Elaborado pela autora.

$\mathrm{Na}$ tarefa 4, "Para ter certeza do seu tamanho, consulte o guia de tamanhos", as voluntárias eram solicitadas a procurar um guia de tamanhos para consultar suas medidas e verificar se haviam feito a escolha certa nas tarefas 1 e 2 . Havia três formas de verificar as medidas: FIT FINDER, o Guia de Tamanhos, e o Guia de Tamanhos Completo. O FIT FINDER foi o mais utilizado por $43 \%$ das voluntárias do Grupo A e B. Em alguns casos, ao acessar a Página do Produto, o link do Guia de Tamanhos estava visível, porém segundos depois, durante o carregamento da página, este link transformava-se no link para acesso ao FIT FINDER. Algumas voluntárias não perceberam esta mudança e outras ficaram um pouco confusas.

No sítio móvel e no completo, o Guia de Tamanhos Completo poderia ser acessado da página do Guia de Tamanhos. No sítio completo também poderia ser acessado por meio do link Glossário de Moda localizado no rodapé do sítio. 
Do grupo A, $13 \%$ das voluntárias e $20 \%$ do Grupo B não acharam nenhuma das três tabelas de medidas (Tabela 7.2).

\begin{tabular}{lcccc} 
& \multicolumn{2}{c}{$\begin{array}{c}\text { Grupo A } \\
\text { (Desktop/laptop) }\end{array}$} & \multicolumn{2}{c}{$\begin{array}{c}\text { Grupo B } \\
\text { (Smartphone) }\end{array}$} \\
\hline Qual tipo de tabela de medidas achou? & No. & $\%$ & No. & \% \\
\hline FIT FINDER & 12 & $40 \%$ & 13 & $43 \%$ \\
FIT FINDER e Guia de Tamanhos & 1 & $3 \%$ & - & - \\
Guia de tamanhos e Guia de tamanhos completo & 1 & $3 \%$ & 3 & $10 \%$ \\
Guia de tamanhos completo & 4 & $13 \%$ & - & - \\
Guia de tamanhos & 8 & $27 \%$ & 8 & $27 \%$ \\
Não usou porque não achou & 4 & $13 \%$ & 6 & $20 \%$ \\
\hline
\end{tabular}

Tabela 7.2 - Tipo de tabela de medidas que encontrou. Fonte: Elaborado pela autora.

No capítulo 6, foi realizada uma análise de tarefas para levantar-se os caminhos possíveis para a realização de cada tarefa, tanto no desktop/laptop quanto no smartphone. Com isso foi possível quantificar o número mínimo de passos necessários para cumpri-las, seguindo a lógica proposta pelo sítio da Dafiti.

Utilizando as gravações dos testes de usabilidade foram contados o número de passos necessários para as voluntárias cumprirem as tarefas. Na Figura 7.6 estão listados: a média, o menor e o maior número de passos realizados pelas voluntárias por tarefa e separado por dispositivo. Na mesma figura está listada a quantidade de caminhos possíveis para realizar as quatro tarefas e os passos mínimos necessários para fins de comparação.

Para evitar distorções acerca da dificuldade percebida de cada tarefa, a Tabela 7.3 mostra quantas voluntárias realizaram-na utilizando determinado número de passos. A título de exemplo, a Tarefa 1, no Grupo A, foi cumprida em 6 a 31 passos, metade das voluntárias precisou de até 11 passos (mais que o dobro do mínimo necessário que são 5) e somente uma voluntária conseguiu realizar a tarefa com o mínimo de passos necessários do caminho B, que são 6 passos. 


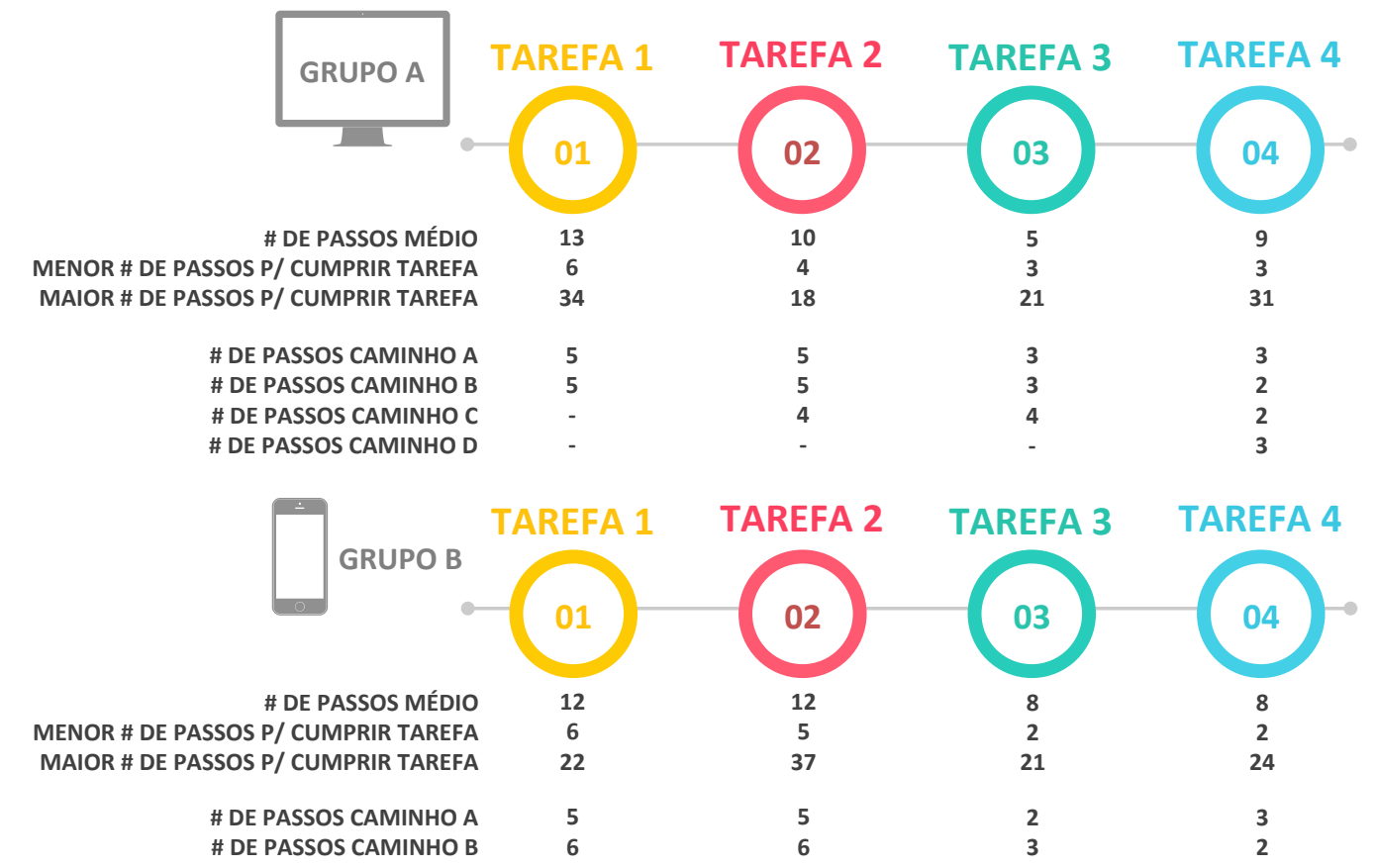

Figura 7.6 - Número de passos necessários para cumprir as tarefas. Fonte: Elaborado pela autora.

\begin{tabular}{|c|c|c|c|c|c|c|c|c|}
\hline \multirow[b]{2}{*}{ \# de passos } & \multicolumn{2}{|c|}{$\begin{array}{c}\text { Tarefa } 1 \\
\text { \# de pessoas }\end{array}$} & \multicolumn{2}{|c|}{$\begin{array}{c}\text { Tarefa } 2 \\
\text { \# de pessoas }\end{array}$} & \multicolumn{2}{|c|}{$\begin{array}{c}\text { Tarefa } 3 \\
\text { \# de pessoas }\end{array}$} & \multicolumn{2}{|c|}{$\begin{array}{c}\text { Tarefa } 4 \\
\text { \# de pessoas }\end{array}$} \\
\hline & Grupo A & Grupo B & Grupo A & Grupo B & Grupo A & Grupo B & Grupo A & Grupo B \\
\hline 2 & - & - & - & - & - & 1 & - & 1 \\
\hline 3 & - & - & - & - & 10 & 2 & 2 & 5 \\
\hline 4 & - & - & 1 & - & 5 & 2 & 4 & 2 \\
\hline 5 & - & - & - & 2 & 7 & 5 & 7 & 5 \\
\hline 6 & 1 & 1 & 2 & 2 & 1 & 4 & 1 & 2 \\
\hline 7 & 2 & 2 & 2 & 3 & 3 & 4 & 2 & 3 \\
\hline 8 & 4 & 1 & 5 & 5 & 1 & 3 & 2 & 4 \\
\hline 9 & 5 & 7 & 5 & 4 & 2 & 1 & 1 & 1 \\
\hline 10 & 2 & 4 & 5 & 3 & - & 2 & 4 & - \\
\hline 11 & 2 & 2 & 3 & - & - & 1 & - & 1 \\
\hline 12 & 2 & 3 & 1 & 1 & - & 1 & 3 & 1 \\
\hline 13 & 3 & 1 & - & 1 & - & 1 & 1 & - \\
\hline 14 & 2 & 1 & - & 2 & - & - & - & - \\
\hline 15 & 2 & 3 & 1 & 3 & - & - & - & 1 \\
\hline 16 & 1 & 1 & 1 & 1 & - & - & - & 1 \\
\hline 17 & - & 1 & 2 & - & - & 1 & 2 & - \\
\hline 18 & - & - & - & - & - & - & - & - \\
\hline 19 & - & 1 & - & - & - & 1 & - & - \\
\hline 20 & - & - & - & - & - & - & - & 1 \\
\hline 21 & - & 1 & 1 & - & 1 & 1 & - & - \\
\hline 22 & - & 1 & 1 & 1 & - & - & - & 1 \\
\hline 23 & 1 & - & - & - & - & - & - & - \\
\hline 24 & - & - & - & - & - & - & - & 1 \\
\hline 25 & - & - & - & - & - & - & - & - \\
\hline 26 & 2 & - & - & - & - & - & - & - \\
\hline 27 & - & - & - & 1 & - & - & - & - \\
\hline 28 & - & - & - & - & - & - & - & - \\
\hline 29 & - & - & - & - & - & - & - & - \\
\hline 30 & - & - & - & - & - & - & - & - \\
\hline 31 & - & - & - & - & - & - & 1 & - \\
\hline 32 & - & - & - & - & - & - & - & - \\
\hline 33 & - & - & - & - & - & - & - & - \\
\hline 34 & 1 & - & - & - & - & - & - & - \\
\hline 35 & - & - & - & - & - & - & - & - \\
\hline 36 & - & - & - & - & - & - & - & - \\
\hline 37 & - & - & - & 1 & - & - & - & - \\
\hline
\end{tabular}

Tabela 7.3 - Número de passos necessários para cumprir as tarefas. Fonte: Elaborado pela autora. 


\subsection{3.}

\section{Resultados do questionário AttrakDiff2 ${ }^{\mathrm{TM}}$}

A última etapa do teste de usabilidade foi a aplicação do questionário AttrakDiff2тM ${ }^{\mathrm{TM}}$ Cada par de palavras tinha o objetivo de medir a percepção das voluntárias em relação à certas qualidades do produto, dividias em: pragmática, hedônica (identidade), hedônica (estímulo) e atração. As respostas foram agrupadas de acordo com a qualidade medida, uma média para cada dupla de palavras foi calculada e então uma média para cada qualidade avaliada (Figura 7.7). Os cálculos foram feitos utilizando os números de todos os teste, em desktop/laptop e smartphone. Os resultados dos dois grupos também foram analisados separadamente para verificar se houve diferença na experiência de interação em desktop/laptop e smartphone.
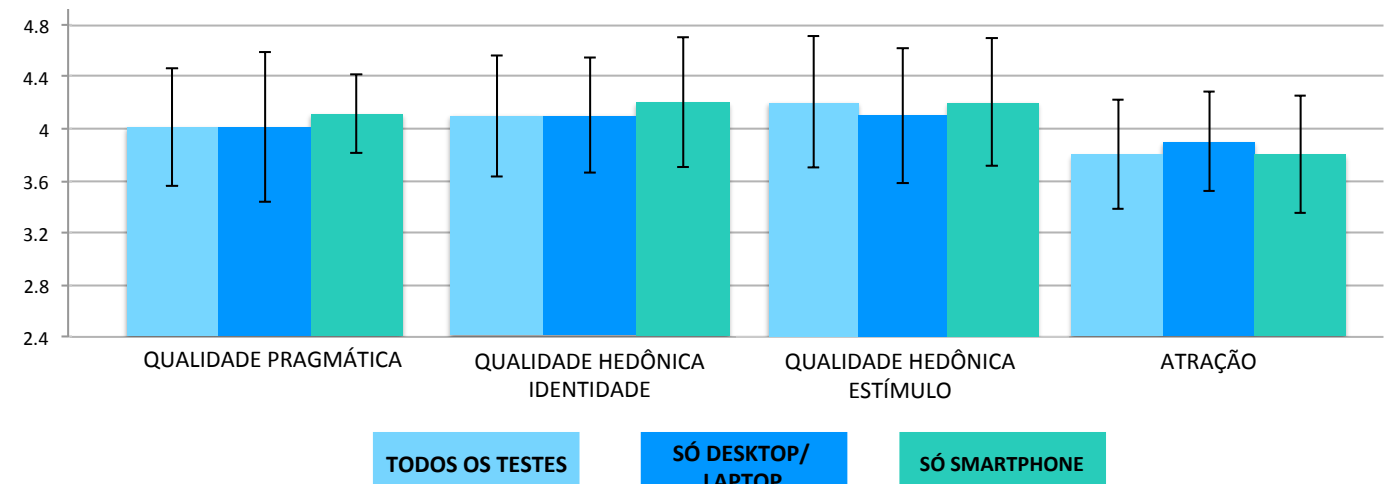
LAPTOP

SÓ SMARTPHONE

\begin{tabular}{lcccccccc}
\hline & QUALIDADE PRAGMÁTICA QUALIDADE HEDÔNICA ID & QUALIDADE HEDÔNICA EST & \multicolumn{2}{c}{ ATRAÇÃO } \\
\hline & Média & DevPad & Média & DevPad & Média & DevPad & Média & DevPad \\
TODOS OS TESTES & 4,0 & 0,45 & 4,1 & 0,47 & 4,2 & 0,50 & 3,8 & 0,42 \\
SÓ DESKTOP/LAPTOP & 4,0 & 0,57 & 4,1 & 0,44 & 4,1 & 0,52 & 3,9 & 0,39 \\
SÓ SMARTPHONE & 4,1 & 0,30 & 4,2 & 0,50 & 4,2 & 0,49 & 3,8 & 0,45 \\
\hline
\end{tabular}

Figura 7.7 - Resultados AttrakDiff2 ${ }^{\mathrm{TM}}$. Fonte: Elaborado pela autora.

Os resultados foram bem similares, não houve diferença considerável entre os testes realizados em desktop/laptop e aqueles realizado em um smartphone. As notas mais baixas foram atribuídas ao item atração. 


\subsection{4.}

\section{Resultados do debriefing}

Após a realização das tarefas no sítio da Dafiti as voluntárias responderam ao debriefing. Dentre as perguntas, 3 eram fechadas e as voluntárias foram solicitadas a justificar suas respostas. Foram elas:

a) A tabela de medidas contém informações claras? Sim/Não. Por quê?

b) Você sente-se segura em relação as informações sobre o caimento da roupa? Sim/Não. Por quê?

c) Com base nas informações disponíveis você tem segurança de que o tamanho escolhido está correto? Sim/Não. Por quê?

As justificativas foram analisadas utilizando-se o método de Análise de Conteúdo (BARDIN, 2011). Nos itens seguintes estão destacadas as principais respostas.

A tabela de medidas continha informações claras? No grupo A, 40\% responderam que as informações expostas na tabela de medidas não eram apresentadas com clareza, no grupo B a porcentagem cai para $33 \%$. Dentre os motivos para as respostas negativas, $25 \%$ das pessoas do grupo A e $50 \%$ do $\mathrm{B}$ não acharam as tabelas (Tabela 7.4). Entre outros motivos listados estava a falta de informações necessárias, ou esperadas nas tabelas. "Poderia indicar como tirar as medidas, talvez com um desenho do corpo, porque essa parte das medidas sempre me deixa confusa", "Eu acho que peso e altura são fatores que podem variar bastante, não indicam necessariamente o tamanho. Prefiro quando tem as medidas em $\mathrm{cm} "$.

Entre outros motivos está a percepção subjetiva das medidas "Porque são medidas subjetivas e o que o outro vê é diferente da minha imagem no espelho", uma voluntária que não conseguiu usar o sistema de medidas por causa da sua altura, não havia tamanho disponível para ela, "Não sei. Não consegui acessar. Talvez pela minha altura $(1,83 \mathrm{~m})$ '”. E ainda houve as que ficaram confusas quanto ao uso do sistema FIT FINDER: “As opções de marca de referência são poucas e não muito acessiveis" e "Achei o input de informação. Além da parte de interação que falta um feedback visual no que eu já marquei”. 
As voluntárias tiveram experiências diferentes, pois dependendo da peça escolhida era oferecido um método para a conferência das medidas, ora o FIT FINDER, ora o link para o Guia de Tamanhos.

FREQUÊNCIA (\# MENÇÕES)

\begin{tabular}{|c|c|c|c|c|}
\hline $\begin{array}{l}\text { A tabela de medidas continha informações } \\
\text { claras? Não. }\end{array}$ & $\begin{array}{c}\text { GRUPO A } \\
\text { DESKTOP/LAPTOP }\end{array}$ & $\%$ & $\begin{array}{c}\text { GRUPO B } \\
\text { SMARTPHONE }\end{array}$ & $\%$ \\
\hline NÃO FOI LOCALIZADA & 3 & $25 \%$ & 5 & $50 \%$ \\
\hline NÃO TEM AS INFORMAÇÕES NECESSÁRIAS & 6 & $50 \%$ & 3 & $30 \%$ \\
\hline OUTROS & 3 & $25 \%$ & 2 & $20 \%$ \\
\hline Total & 12 & $100 \%$ & 10 & $100 \%$ \\
\hline
\end{tabular}

Tabela 7.4 - Respostas negativas à pergunta: “A tabela de medidas continha informações claras?”. Fonte: Elaborado pela autora.

Do grupo A $60 \%$ das voluntárias e $67 \%$ do grupo B responderam positivamente à pergunta: A tabela de medidas continha informações claras? (Tabela 7.5). Para os dois grupos o principal motivo da percepção positiva foi a adequação das informações expostas pelo sítio, "Porque tinha os dados necessários", "Porque as medidas informadas são suficientes para saber o tamanho da roupa" "Porque tinha as medidas de busto e cintura e ainda uma opção de 'como medir'”.

Entre os demais motivos destacam-se as respostas das voluntárias que acharam as informações claras, porém ficaram com dúvidas acerca das suas medidas: "Mas o resultado do tamanho deu errado", "Os dados estavam claros, as informações de medidas, porém senti insegurança se os dados estavam corretos. Não percebi se tinha a informação do tamanho da modelo, isso me ajuda a entender a modelagem”. E também as respostas das voluntárias que não acharam as informações das tabelas práticas: "Porém acredito que a opção por medida em fita métrica pode não ser tão prático visto que necessito de disponibilidade e tempo e fita métrica". 
FREQUÊNCIA (\# MENÇÕES)

\begin{tabular}{lcccc}
\hline $\begin{array}{l}\text { A tabela de medidas continha informações } \\
\text { claras? Sim. }\end{array}$ & $\begin{array}{c}\text { GRUPO A } \\
\text { DESKTOP/LAPTOP }\end{array}$ & $\mathbf{\%}$ & $\begin{array}{c}\text { GRUPO B } \\
\text { SMARTPHONE }\end{array}$ & $\mathbf{\%}$ \\
$\begin{array}{l}\text { INFORMAÇÕES CLARAS MAS QUE DEIXAM } \\
\text { DÚVIDAS }\end{array}$ & 1 & $6 \%$ & 2 & $10 \%$ \\
FACILIDADE & - & - & 3 & $15 \%$ \\
\hline OFERECIA INFORMAÇÕES ADEQUADAS & 13 & $72 \%$ & 12 & $60 \%$ \\
INFORMAÇÕES CLARAS MAS NÃO SÃO & 1 & $6 \%$ & 1 & $5 \%$ \\
PRÁTICAS & 1 & $6 \%$ & 1 & $5 \%$ \\
SEGURANÇA NAS INFORMAÇÕES & 0 & $0 \%$ & 1 & $5 \%$ \\
FAMILIARIDADE & 1 & $6 \%$ & - & - \\
\hline DIFICULDADE PARA ACESSAR & 1 & $6 \%$ & - & - \\
\hline GOSTOU DO SISTEMA & $\mathbf{1 8}$ & $\mathbf{1 0 0 \%}$ & $\mathbf{2 0}$ & $\mathbf{1 0 0 \%}$ \\
\hline Total & & &
\end{tabular}

Tabela 7.5 - Respostas afirmativas à pergunta: "A tabela de medidas continha informações claras?" Fonte: Elaborado pela autora.

\section{Você sente-se segura em relação às informações sobre o caimento da} roupa? Do grupo A, 60\% das voluntárias e $83 \%$ do grupo B responderam negativamente à pergunta (Tabela 7.6). O motivo principal do grupo $\mathrm{B}$ para a resposta negativa foi a falta de identificação com as fotos, com $40 \%$ das respostas, "Porque as imagens são feitas em modelos de um estereótipo bem diferente dos compradores", "Não muito, porque em geral as fotos das modelos não se assemelham com meu tipo físico", "Porque eu sei que o caimento pode não ser o que está na foto, podem ter ajustes na peça”, "Não consegui visualizar as opções sobre caimento da peça", "Nas fotos não consegui ver pois só tinha 1 foto tirada de 1 ângulo", "Porque o que vemos na tela nem sempre é o que a peça representa”.

\section{FREQUÊNCIA (\# MENÇÕES)}

\begin{tabular}{|c|c|c|c|c|}
\hline $\begin{array}{l}\text { Você sente-se segura em relação às } \\
\text { informações sobre o caimento da roupa? } \\
\text { Não }\end{array}$ & $\begin{array}{c}\text { GRUPO A } \\
\text { DESKTOP/LAPTOP }\end{array}$ & $\%$ & $\begin{array}{l}\text { GRUPO B } \\
\text { SMARTPHONE }\end{array}$ & $\%$ \\
\hline NÃO IDENTIFICOU-SE COM AS FOTOS & 4 & $22 \%$ & 10 & $40 \%$ \\
\hline $\begin{array}{l}\text { TERIA QUE EXPERIMENTAR A PEÇA PARA } \\
\text { TER CERTEZA }\end{array}$ & 2 & $11 \%$ & 5 & $20 \%$ \\
\hline NÃO HAVIA INFORMAÇÕES SUFICIENTES & 4 & $22 \%$ & 7 & $28 \%$ \\
\hline INSEGURANÇA A RESPEITO DO FIT FINDER & 1 & $6 \%$ & 1 & $4 \%$ \\
\hline $\begin{array}{l}\text { INSEGURANÇA A RESPEITO DAS MEDIDAS } \\
\text { FORNECIDAS }\end{array}$ & 1 & $6 \%$ & 1 & $4 \%$ \\
\hline RISCO PERCEBIDO & 2 & $11 \%$ & 1 & $4 \%$ \\
\hline $\begin{array}{l}\text { FALTA DE CONHECIMENTO TÉCNICO SOBRE } \\
\text { O ASSUNTO }\end{array}$ & 2 & $11 \%$ & - & - \\
\hline NÃO GOSTOU DO SITE & 1 & $6 \%$ & - & - \\
\hline OUTROS & 1 & $6 \%$ & - & - \\
\hline Total & 18 & $100 \%$ & 25 & $100 \%$ \\
\hline
\end{tabular}

Tabela 7.6 - Respostas negativas à pergunta: "Você sente-se segura em relação às informações sobre o caimento da roupa?" Fonte: Elaborado pela autora. 
Do grupo A, 40\% das voluntárias e 17\% do grupo B sentiram-se satisfeitas quanto às informações sobre o caimento das peças de roupas apresentadas pelo sítio (Tabela 7.7). Entre os motivos que as deixaram seguras em relação ao caimento da roupa está a identificação com as fotos, "Porque as fotos são muito informativas sobre o material e caimento", "Com a imagem disponibilizada foi possível ter ideia mas seria melhor ter a roupa vestida numa pessoa. Os comentários (de outros usuários) ajudaram" , "Por causa das fotos em modelo. Pra mim o caimento não está ligado ao guia de tamanhos", "A foto com a modelo vestida me transmitiu segurança".

Destacaram-se também as respostas das voluntárias que se sentiram-se seguras com relação as informações de caimento fornecidas pelo sítio, "Me conheço e me senti segura nas informações dadas pelo site", "Por ter mais detalhes no FIT FINDER e informações da peça consigo ter uma ideia melhor", "Porque o tamanho sugerido em geral faz sentido com os tamanhos que eu geralmente compro e servem”.

FREQUÊNCIA (\# MENÇÕES)

\begin{tabular}{lcccc}
\hline $\begin{array}{l}\text { Você sente-se segura em relação às } \\
\text { informações sobre o caimento da roupa? } \\
\text { Sim. }\end{array}$ & $\begin{array}{c}\text { GRUPO A } \\
\text { DESKTOP/LAPTOP }\end{array}$ & $\mathbf{\%}$ & $\begin{array}{c}\text { GRUPO B } \\
\text { SMARTPHONE }\end{array}$ & $\%$ \\
$\begin{array}{l}\text { IDENTIFICOU-SE COM AS FOTOS } \\
\text { SEGURANÇA A RESPEITO DAS }\end{array}$ & 5 & $42 \%$ & 2 & $40 \%$ \\
$\begin{array}{l}\text { INFORMAÇÕES FORNECIDAS PELO SITE } \\
\text { BASEOU-SE EM EXPERIÊNCIAS PRÉVIAS DE } \\
\text { COMPRAS }\end{array}$ & 2 & $17 \%$ & 3 & $60 \%$ \\
$\begin{array}{l}\text { SENTIU-SE SEGURA COM AS INFORMAÇÕES } \\
\text { MAS AINDA SENTE NECESSIDADE DE }\end{array}$ & 2 & $17 \%$ & - & - \\
$\begin{array}{l}\text { EXPERIMENTAR } \\
\text { O TAMANHO NÃO REPRESENTOU UM }\end{array}$ & 1 & $8 \%$ & - & - \\
RISCO AO COMPRAR & 1 & $8 \%$ & - & - \\
PODE COMPRAR E TROCAR & 1 & $8 \%$ & - & - \\
Total & $\mathbf{1 2}$ & $\mathbf{1 0 0 \%}$ & $\mathbf{5}$ & $100 \%$ \\
\hline
\end{tabular}

Tabela 7.7 - Respostas afirmativas à pergunta: "Você sente-se segura em relação às informações sobre o caimento da roupa?" Fonte: Elaborado pela autora.

\section{Com base nas informações disponíveis você tem segurança de que o} tamanho escolhido está correto? Do grupo A, 47\% das voluntárias e $60 \%$ do grupo $\mathrm{B}$ deram respostas negativas à pergunta (Tabela 7.8). As voluntárias não tiveram informações suficientes para terem certeza que a peça escolhida caberialhes-ia, quando a recebesse em casa, "Porque não tem como saber como veste no 
corpo pelas informações dadas", "Não exatamente. Porque já realizei compras no site que deram errado, justamente porque não tinham informações completas sobre o material/tecido da roupa etc. ”.

Além de não ter informação suficiente, outras voluntárias não confiaram nas que foram fornecidas pelo sítio, "Por mais que ache as minhas medidas na tabela sempre tenho dúvida quanto às variações de fabricação. Dependendo da peça, se a minha medida ficar no limite. Para cima eu peço o número maior". "Porque as medidas podem estar erradas, ou está faltando informação”.

Dos outros motivos mencionados com menor frequência pelas voluntárias destacam-se: a percepção da disparidade das medidas praticadas pelos fabricantes e a necessidade de terem de experimentar a peça para certificarem-se do tamanho. "Porque modelagem varia muito de marca para marca", "Porque o P de uma marca pode ser do tamanho de um $M$ da outra", "Na verdade não sei dizer já que não tenho como experimentar e saber como ficaria o caimento da peça", "Só teria certeza após comprovar com a chegada da peça”.

FREQUÊNCIA (\# MENÇõES)

\begin{tabular}{|c|c|c|c|c|}
\hline $\begin{array}{l}\text { Com base nas informações disponíveis } \\
\text { você tem segurança de que o tamanho } \\
\text { escolhido está correto? Não. }\end{array}$ & $\begin{array}{c}\text { GRUPO A } \\
\text { DESKTOP/LAPTOP }\end{array}$ & $\%$ & $\begin{array}{c}\text { GRUPO B } \\
\text { SMARTPHONE }\end{array}$ & $\%$ \\
\hline $\begin{array}{l}\text { NÃO CONFIA NAS INFORMAÇÕES } \\
\text { FORNECIDAS PELO SITE }\end{array}$ & 2 & $14 \%$ & 4 & $22 \%$ \\
\hline INFORMAÇÕES INSUFICIENTES & 4 & $29 \%$ & 7 & $39 \%$ \\
\hline $\begin{array}{l}\text { TERIA QUE EXPERIMENTAR PARA TER } \\
\text { CERTEZA }\end{array}$ & 1 & $7 \%$ & 2 & $11 \%$ \\
\hline DISPARIDADE DE MEDIDAS & 4 & $29 \%$ & 2 & $11 \%$ \\
\hline $\begin{array}{l}\text { INFORMAÇÕES INSUFICIENTES NO FIT } \\
\text { FINDER }\end{array}$ & 1 & $7 \%$ & - & - \\
\hline $\begin{array}{l}\text { FIT FINDER NÃO ACHOU UM TAMANHO } \\
\text { ADEQUADO PARA A VOLUNTÁRIA }\end{array}$ & - & - & 1 & $6 \%$ \\
\hline RISCO PERCEBIDO & 1 & $7 \%$ & 1 & $6 \%$ \\
\hline $\begin{array}{l}\text { MEDIDAS OK MAS CAIMENTO É UM } \\
\text { PROBLEMA }\end{array}$ & 1 & $7 \%$ & 1 & $6 \%$ \\
\hline Total & 14 & $100 \%$ & 18 & $100 \%$ \\
\hline
\end{tabular}

Tabela 7.8 - Respostas negativas à pergunta: "Com base nas informações disponíveis você tem segurança de que o tamanho escolhido está correto?” Fonte: Elaborado pela autora.

Do grupo A, 53\% das voluntárias e $40 \%$ do grupo B deram respostas afirmativas para a pergunta: "Com base nas informações disponíveis você tem segurança de que o tamanho escolhido está correto?” (Tabela 7.9). 63\% do grupo A respondeu sim para esta pergunta pois sentiram confiança nas informações fornecidas pelo sítio: "Porque acho o guia de tamanhos detalhado o suficiente", 
"Porque confiei nas informações", "Pois o guia de tamanhos me ajudou a ter essa certeza”. Apenas 17\% do grupo B deu o mesmo motivo.

No grupo B, a justificativa mais mencionada pelas voluntárias para a resposta afirmativa foi a utilização de experiências prévias para a escolha do tamanho, 58\% declararam terem se baseado em seu histórico de compras para escolherem o tamanho.

\section{FREQUÊNCIA (\# MENÇÕES)}

\begin{tabular}{lcccc}
\hline $\begin{array}{l}\text { Com base nas informações disponíveis } \\
\text { você tem segurança de que o tamanho } \\
\text { escolhido está correto? Sim. }\end{array}$ & $\begin{array}{c}\text { GRUPO A } \\
\text { DESKTOP/LAPTOP }\end{array}$ & $\mathbf{\%}$ & $\begin{array}{c}\text { GRUPO B } \\
\text { SMARTPHONE }\end{array}$ & $\%$ \\
$\begin{array}{l}\text { BASEOU-SE EM EXPERIÊNCIAS PRÉVIAS } \\
\text { CONFIANÇA NAS INFORMAÇÕES }\end{array}$ & 4 & $25 \%$ & 7 & $58 \%$ \\
$\begin{array}{l}\text { FORNECIDAS PELO SITE } \\
\text { USO DA FITA MÉTRICA }\end{array}$ & - & $63 \%$ & 2 & $17 \%$ \\
$\begin{array}{l}\text { IDENTIFICOU-SE COM AS FOTOS } \\
\text { NÃO TERIA 100\% DE CERTEZA SÓ FARIA UM }\end{array}$ & - & - & 1 & $8 \%$ \\
INVESTIMENTO BAIXO & - & - & 1 & $8 \%$ \\
$\begin{array}{l}\text { MEDIDAS OK MAS CAIMENTO É UM } \\
\text { PROBLEMA }\end{array}$ & 2 & $13 \%$ & - & $8 \%$ \\
Total & $\mathbf{1 6}$ & $\mathbf{1 0 0 \%}$ & $\mathbf{1 2}$ & - \\
\hline
\end{tabular}

Tabela 7.9 - Respostas afirmativas à pergunta: "Com base nas informações disponíveis você tem segurança de que o tamanho escolhido está correto?” Fonte: Elaborado pela autora.

As demais perguntas do debriefing estão destacadas a seguir:

\section{As informações no sítio para a sua compra foram:}

Suficientes

Insuficientes

As respostas das participantes foram baseadas em uma escala tipo Likert de 7 pontos variando de 7 (informações suficientes) a 1 (informações insuficientes). A média das respostas foi 5,2 e a moda 6 para o grupo A e a média de 5 e moda 6 para o grupo B (Figura 7.8). Estes resultados demonstram que a percepção geral das voluntárias é a de que o sítio oferece informações suficientes, porém ao responderem as demais perguntas foi possível verificar que as voluntárias foram mais "generosas" nesta pergunta.

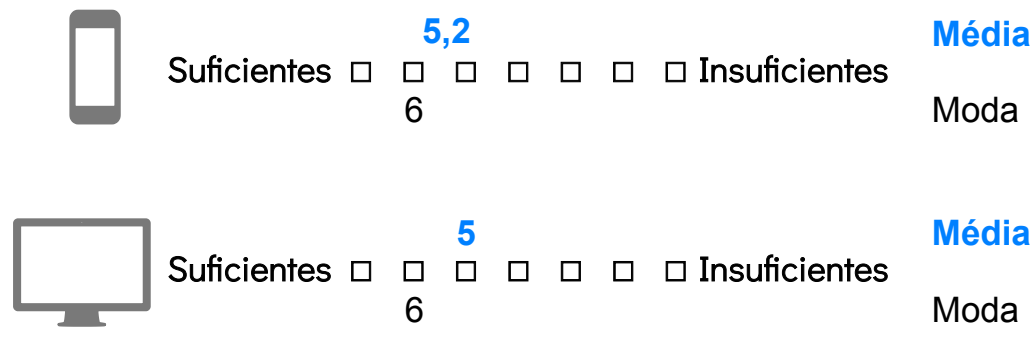

Figura 7.8 - Respostas à pergunta: “As informações no sítio para a sua compra foram: suficientesinsuficientes". Fonte: Elaborado pela autora. 


\section{As políticas de trocas estão claras?}

Dentre as voluntárias do grupo A, 67\% acharam que as Políticas de Trocas e devoluções estavam claras e o grupo B 87\% (Tabela 7.10). Observou-se que, durante $\mathrm{o}$ teste de usabilidade, parte das voluntárias que responderam negativamente à pergunta não encontraram ou não leram as políticas apresentadas no sítio.

\begin{tabular}{lcccc} 
& \multicolumn{2}{c}{$\begin{array}{c}\text { Grupo A } \\
\text { (Desktop/laptop) }\end{array}$} & \multicolumn{2}{c}{$\begin{array}{c}\text { Grupo B } \\
\text { (Smartphone) }\end{array}$} \\
\hline As políticas de trocas estão claras? & No. & \% & No. & \% \\
\hline SIM & 20 & $67 \%$ & 26 & $87 \%$ \\
NÃO & 10 & $33 \%$ & 4 & $13 \%$ \\
\hline
\end{tabular}

Tabela 7.10 - Respostas à pergunta: “As políticas de trocas estão claras?” Fonte: Elaborado pela autora.

Geralmente quando você compra on-line, o preço é um fator decisório? 97\% das voluntárias do grupo A e 67\% do grupo B responderam que sim (Tabela 7.11).

\begin{tabular}{lcccc} 
& \multicolumn{2}{c}{$\begin{array}{c}\text { Grupo A } \\
\text { (Desktop/laptop) }\end{array}$} & \multicolumn{2}{c}{$\begin{array}{c}\text { Grupo B } \\
\text { (Smartphone) }\end{array}$} \\
\hline $\begin{array}{l}\text { Geralmente, quando você compra on-line } \\
\text { o preço é um fator decisório? }\end{array}$ & No. & $\%$ & No. & $\%$ \\
\hline SIM & 29 & $97 \%$ & 20 & $67 \%$ \\
NÃO & 1 & $3 \%$ & 10 & $33 \%$ \\
\hline
\end{tabular}

Tabela 7.11 - Respostas à pergunta: "Geralmente, quando você compra on-line o preço é um fator decisório?" Fonte: Elaborado pela autora.

\section{Quais outros fatores influenciam sua decisão de compra?}

Mesmo já tendo respondido à pergunta sobre a importância do preço na decisão de compra, fatores financeiros, tais como: o preço do frete e facilidade de parcelamento, foram os mais apontados pelas voluntárias. Outro ponto de destaque é a comodidade/praticidade que a compra on-line proporciona assim como a oferta de produtos que só podem ser encontrados em sítios de e-commerce (Tabela 7.12). 
FREQUÊNCIA (\# MENÇÕES)

\begin{tabular}{|c|c|c|c|c|}
\hline $\begin{array}{l}\text { Quais outros fatores influenciam sua } \\
\text { decisão de compra? (Além do preço) }\end{array}$ & $\begin{array}{c}\text { GRUPO A } \\
\text { DESKTOP/LAPTOP }\end{array}$ & $\%$ & $\begin{array}{c}\text { GRUPO B } \\
\text { SMARTPHONE }\end{array}$ & $\%$ \\
\hline COMODIDADE/PRATICIDADE & 13 & $18 \%$ & 12 & $22 \%$ \\
\hline VARIEDADE & 2 & $3 \%$ & 2 & $4 \%$ \\
\hline AVALIAÇÕES & 3 & $3 \%$ & 2 & $4 \%$ \\
\hline FINANCEIRO & 16 & $21 \%$ & 14 & $25 \%$ \\
\hline CONFIANÇA & 5 & $3 \%$ & 2 & $4 \%$ \\
\hline ENTREGA & 9 & $12 \%$ & 8 & $15 \%$ \\
\hline DISPONIBILIDADE DO PRODUTO & 5 & $11 \%$ & 7 & $13 \%$ \\
\hline CARACTERÍSTICAS DO PRODUTO & 5 & $5 \%$ & 3 & $5 \%$ \\
\hline POLÍTICA DE TROCA & 2 & $2 \%$ & 1 & $2 \%$ \\
\hline RECURSOS DO SITE & 4 & $2 \%$ & 1 & $2 \%$ \\
\hline OUTROS & 2 & $5 \%$ & 3 & $5 \%$ \\
\hline Total & 66 & $83 \%$ & 55 & $100 \%$ \\
\hline
\end{tabular}

Tabela 7.12 - Respostas à pergunta: "Quais outros fatores influenciam sua decisão de compra? (Além do preço)". Fonte: Elaborado pela autora.

\section{Como você escolheu o seu tamanho?}

Com o intuito de fazer as voluntárias refletirem acerca do tamanho da roupa, elas foram questionadas sobre como fizeram para escolher o tamanho das peças de roupa durante a execução das tarefas 1 e 2 do teste de usabilidade. A questão sobre o tamanho e o caimento foram pontos amplamente discutidos pelos especialistas durante as entrevistas e pelos usuários tanto na durante a entrevista exploratória quanto no questionário (capítulo 5). 63\% das voluntárias do Grupo A e $83 \%$ do grupo B usaram informações obtidas em compras anteriores para escolherem seus tamanhos (Tabela 7.13): “Normalmente sei que meu tamanho é $G$, então selecionei as peças sem observar a tabela de medidas", "Com base em compras anteriores", "É o tamanho que compro em loja fisica normalmente". $13 \%$ de ambos os grupos usaram os recursos oferecidos pelo sítio (como o Guia de tamanhos e o FIT FINDER): "Com base na estimativa oferecida pelo site, apesar da insegurança", "Pela descrição da peça", "P ou M, e me utilizei do FIT FINDER para ser mais assertiva”. 13\% do grupo A declararam terem usado tanto o histórico de compras anteriores quanto os recursos oferecidos pelo sítio. Entre os "Outros", destacam-se as voluntárias que tiveram de "adivinhar" os seus tamanhos: "Por intuição", "No chute", e aquela que por julgar não encaixar-se nos padrões dos tamanhos femininos recorreu à seção de roupas masculinas para escolher as peças nas tarefas 1 e 2: "Não me sinto confortável com as roupas femininas por sempre serem menores e mais justas. Escolhi a parte masculina por ter certeza de que ficarão confortáveis e que caberão em mim”. 


\begin{tabular}{lcccc} 
& \multicolumn{3}{c}{ FREQUÊNCIA (\# MENÇÕES) } \\
\hline Como você escolheu o seu tamanho & $\begin{array}{c}\text { GRUPO A } \\
\text { DESKTOP/LAPTOP }\end{array}$ & $\mathbf{\%}$ & $\begin{array}{c}\text { GRUPO B } \\
\text { SMARTPHONE }\end{array}$ & $\mathbf{\%}$ \\
HISTÓRICO DE COMPRAS & 19 & $63 \%$ & 25 & $83 \%$ \\
USOU RECURSOS DO SITE & 4 & $13 \%$ & 4 & $13 \%$ \\
USOU AMBOS (HISTÓRICO E RECURSOS) & 4 & $13 \%$ & - & - \\
OUTROS & 3 & $10 \%$ & 1 & $3 \%$ \\
Total & $\mathbf{3 0}$ & $\mathbf{1 0 0 \%}$ & $\mathbf{3 0}$ & $\mathbf{1 0 0 \%}$ \\
\hline
\end{tabular}

Tabela 7.13 - Respostas à pergunta: “Como você escolheu o seu tamanho?” Fonte: Elaborado pela autora.

\section{2.}

\section{Sínteses}

\subsection{1}

\section{Síntese do resultado do teste de usabilidade}

Tarefa 1: Nenhuma das voluntárias realizou o teste no número mínimo de passos. Este resultado é esperado pois nesta tarefa as voluntárias foram solicitadas a simular uma compra e para chegarem ao objetivo navegavam no sítio em busca de uma peça que atendesse aos requisitos da tarefa e satisfizesse o seu gosto pessoal. A maioria das voluntárias dos Grupos A e B, 87\%, realizou o tarefa entre 6 e 16 passos.

Tarefa 2: O resultado foi similar aos da tarefa 1, nenhuma das voluntárias realizou o teste no número mínimo de passos. Nesta tarefa as voluntárias também eram solicitadas a simular uma compra. Vale ressaltar a confusão com a nomenclatura das peças; a tarefa 1 consistia em simular a compra de uma blusa manga curta e na tarefa 2 de uma camisa manga longa para trabalhar. A maioria das voluntárias dos Grupos A e B realizou o tarefa entre 6 e 16 passos. De uma forma geral, percebeu-se que as voluntárias estavam mais familiarizadas com o sítio nesta tarefa depois de terem realizado a primeira e sentiam-se mais à vontade.

Tarefa 3: Esta foi a tarefa com maior diferença entre os testes realizados no desktop/laptop e no smartphone. No Grupo A 97\% das voluntárias realizaram a tarefa entre 3 e 9 passos, embora 33\% a realizassem no número mínimo possível de passos, 3. No Grupo B, 90\% realizou entre 2 e 13 passos, uma pessoa realizou no número mínimo, 2 passos, e 5 passos foi o número de passos mais frequente, 
utilizado por $17 \%$. As políticas de trocas eram somente acessadas no rodapé da página no sítio móvel, enquanto no sítio completo era possível acessá-las pelo link no rodapé, no topo da página e uma barra fixa na área superior, e acessando os links de Ajuda e Atendimento. Esta foi a tarefa realizada com mais facilidade, apesar de ser a que houve uma percepção de dificuldade maior. Grande parte das voluntárias fazia comentários negativos antes de iniciarem a tarefa: "Agora complicou”, "É um desafio descobrir como devolve".

As voluntárias eram solicitadas apenas a achar as instruções de devolução, porém algumas iniciaram o processo. Nas instruções não havia indicação de que o usuário tinha de estar logado no sistema para poder acessar o perfil e, então, realizar o processo de devolução ou troca. Das voluntárias que optaram por tentar realizar o processo de devolução, algumas ficaram presas em um looping, e não conseguiam prosseguir. Ademais, houve uma limitação na tarefa; não ficou claro se as voluntárias teriam dificuldade de executar uma devolução, muitas delas não liam as instruções e consideravam a tarefa como terminada assim que achavam a informação. Uma investigação sobre o entendimento das instruções seria necessária para avaliar a compreensão das informações e o quanto isso influenciaria o risco percebido.

As instruções de devolução do sítio são muito longas para serem lidas em uma tela pequena de um smartphone, as voluntárias tinham de rolar a página diversas vezes para chegarem ao fim.

Tarefa 4: No Grupo A, 90\% da voluntárias cumpriram a tarefa em até 17 passos. No Grupo B, 90\% cumpriram em até 16 passos. Apesar de a maioria ter achado algum tipo de tabela ou guia de tamanhos não significou que estivessem seguras com as informações expostas.

Nas tarefas 1 e 2 notou-se que a grande quantidade de filtros disponível muitas vezes atrapalhava as voluntárias. Dependendo da combinação de filtros feita, resultava em um número baixo de peças encontradas e as voluntárias atrapalhavam-se para limpar os filtros ou para perceber quais estavam ativos. Estes problemas agravavam-se no testes realizados em smartphone.

O filtro de tamanho é especialmente confuso (Figura 7.9), há uma gama enorme de opções para escolher, as voluntárias ficavam com dúvidas. Outro problema dos filtros eram os resultados. Ao filtrar por camisas femininas havia 
nos resultados bodies, peças masculinas, roupas de ginástica entre outras peças que não atendiam àquela solicitação.

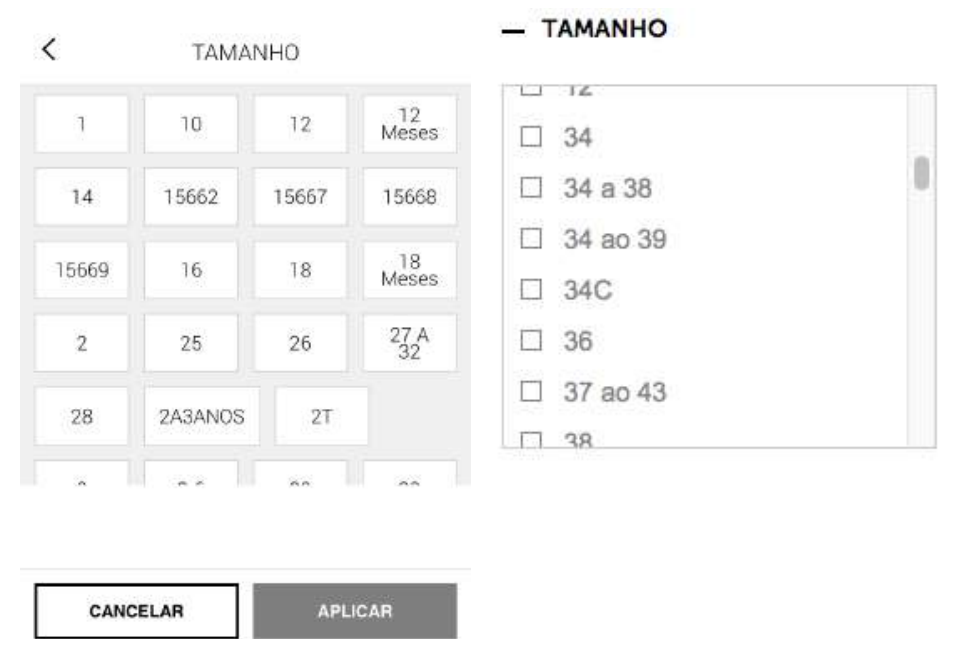

Figura 7.9 - Alguns dos tamanhos disponíveis no filtro de tamanhos, sítio móvel (à esq.) e do sítio completo (à dir). Fonte: https://dafiti.com.br

A falta de conhecimento técnico sobre as peças também é uma barreira para a compra on-line. Houve muita confusão a respeito da nomenclatura das peças (o que é blusa, o que é camisa) da identificação dos tecidos. O caimento de uma peça é determinado em grande parte pelo tecido utilizado.

As voluntárias recorrem com bastante frequência ao sistema de busca interna do sítio e ao invés de auxiliá-las criava mais dificuldade. A busca do sítio da Dafiti só realiza pesquisa de produtos, quando outros termos são procurados como: Guia de Tamanhos ou Política de Devolução (muito usados nas tarefas 3 e 4) o sistema não retorna com resultados. A busca também não considera erros de ortografia e nem termos similares, uma voluntária errou e digitou "femenino" e não obteve resultados. Outra digitou "camisa de manga comprida" e não "longa", e também não obteve resultados.

As voluntárias demonstraram muito receio para realizar as tarefas 3 e 4 , principalmente a 3, "Não tenho noção de onde achar (o Guia de Tamanhos)", "Não sei onde consultar o Guia de Tamanhos". Quanto a tarefa 4, algumas voluntárias nem sabiam da possiblidade de devolver uma peça "Existe essa possibilidade?". 


\subsection{2.}

\section{Síntese dos resultados do questionário Attrakdiff2 ${ }^{\mathrm{TM}}$}

Nesta pesquisa foi considerado como base o estudo do Hassenzahl (2007) (capítulo 2), o autor defende que os atributos de um produto podem ser categorizados em:

Pragmática (utilitário): refere-se à habilidade percebida do produto em atingir metas de fazer;

Hedônica: refere-se à habilidade percebida em dar suporte ao usuário em atingir metas de ser ou estar. A qualidade hedônica pode ser dividida em três subcategorias: identificação, estimulação e evocação;

A usabilidade pode ser uma medida da qualidade pragmática de um produto, pois diz respeito ao cumprimento de tarefas e objetivos, que por sua vez estão ligados ao comportamento utilitário do usuário (BABIN; DARDEN; GRIFFIN, 1994). E a UX estaria ligada às qualidades hedônicas de um produto.

Foi utilizado o questionário AttrakDiff2, desenvolvido especificamente para medir a UX da interação do usuário com um produto. Os resultados mostraram que de uma forma geral as voluntárias do Teste de Usabilidade tiveram uma experiência mediana em todos os aspectos medidos pelo AttrakDiff2 (Qualidade pragmática, qualidade hedônica identidade, qualidade hedônica estímulo e atração). As menores notas foram atribuídas à qualidade atração, mas mesmo obtendo o resultado mais baixo não houve uma diferença relevante em relação as outras qualidades medidas. Os resultados indicaram uma UX similar nas duas versões do sítio da Dafiti, o móvel e o completo.

Não existe uma definição consolidada do que é a UX, profissionais e estudiosos ainda discordam sobre alguns pontos (ROTO et al., 2010) talvez por esta razão ainda não exista uma técnica que a meça corretamente. Por causa da complexidade da experiência do usuário, sua avaliação tende a ser igualmente complexa (MASHAPA; VAN GREUNEN, 2010). Sugere-se, em um estudo futuro, aplicar uma segunda técnica e comparar os resultados. 


\subsection{3.}

\section{Síntese dos resultados do Debriefing}

1. As informações disponíveis no sítio para a sua compra foram: INSUFICIENTES-SUFICIENTES

Para esta pergunta foi utilizada uma escala tipo Likert de 7 pontos, o 1 representava o maior grau de insuficiência e o 7 suficiência. A média de respostas foi 5,2 e a moda 6 para o Grupo A e uma média de 5 e moda 6 para o Grupo B. Não houve uma diferença significativa entre o Grupo A e B, os dois grupos mostraram-se bastante satisfeitos com a quantidade de informação oferecida no sítio Dafiti.com.br. No entanto, as respostas às demais perguntas contradisseram esta percepção de suficiência de informação. Como no teste de usabilidade realizado por Sun e May (2013), houve a percepção de que as voluntárias inicialmente não se sentiam à vontade para expressar sentimentos negativos em relação à sua interação com o sítio, talvez por ter sido a primeira pergunta após a execução do teste de usabilidade, possivelmente sentiram-se na obrigação de serem mais suaves na resposta. Porém ao decorrer do debriefing elas foram dando respostas menos condicentes.

\section{A tabela/guia de medidas contém informações claras? Sim $\square$ Não $\square$ Porque?}

As respostas dos dois grupos foram similares, 60\% do Grupo A e 67\% do Grupo B deram respostas afirmativas. No entanto, uma voluntária do Grupo A e duas do Grupo B responderam que a tabela/guia de medidas continha informações claras, mas não confiaram nos resultados do FIT FINDER ou nas informações do Guia de Tamanhos. Esse dado indica que apesar da resposta afirmativa, a informação fornecida causou dúvida nas voluntárias e o número de respostas negativas poderia ser maior se considerássemos essas respostas.

$\mathrm{Na}$ página do Guia de Tamanhos Completo haviam explicações como a usuária deveria medir-se, mas a minoria das voluntárias chegou até lá, uma delas chegou a comentar que esta informação seria útil para a escolha do tamanho da roupa. 
O FIT FINDER calculava o tamanho em cima de algumas informações, mas não fornecia o tamanho em $\mathrm{cm}$ e algumas voluntárias sentiram-se inseguras com esse resultado sentindo falta de uma tabela com a centimetragem da peça.

Mesmo entre as voluntária que consideraram as informações das tabelas ou guia de medidas, houve uma parcela que declarou ainda ter dúvidas.

3. Você sente-se segura em relação as informações sobre o caimento da peça? Sim Não $\square$ Porque?

Menos da metade das voluntárias do Grupo A, 40\% e apenas $17 \%$ do Grupo $\mathrm{B}$ sentiram-se se satisfeitas quanto às informações sobre o caimento das peças de roupas apresentadas pelo sítio. O alto índice de respostas negativas do Grupo B, $83 \%$, indica maior dificuldade de visualizar este tipo de informação de um smartphone. Os motivos mais citados em ambos os grupos foram a falta de identificação com as fotos, a necessidade de experimentar a peça para ter certeza do caimento e a falta de informações sobre o caimento. A necessidade do contato tátil com o produto é a principal justificativa para os consumidores que preferem comprar em lojas físicas ao em vez de o fazerem on-line (KPMG, 2017).

Vale ressaltar que entre as voluntárias que se sentiram-se seguras com as informações sobre caimento houve identificação com as fotos do sítio, o oposto do grupo que deu uma resposta negativa à essa pergunta. A fotografia de moda é sem dúvidas um importante supridor de imagens e uma das mídias mais poderosas, em se tratando de comunicar imagens de homens e mulheres (BARNARD, 2003).

Outro dado interessante foram as voluntárias que se declararam satisfeitas com as informações sobre o caimento, mas basearam a sua escolha de tamanho em sua experiência prévia de compras e não nos dados fornecidos pelo sítio.

O que determina o caimento de uma roupa é a maneira como o tecido foi cortado e sua composição (Capítulo 3). Tecidos de malha são mais elásticos e adaptam-se mais facilmente às saliências do corpo. Tecidos planos por serem menos elásticos precisam ser ajustados ao corpo com mais exatidão. As informações disponíveis em sítios de vestuário, não só no da Dafiti, dão pouca informação sobre as características de caimento de uma peça, ou estas são extremamente técnicas, como a composição do tecido. Sem um conhecimento 
prévio sobre as variedades e propriedades de um tecido esta informação torna-se útil somente para pessoas que têm alergia à algum dos fios, por exemplo.

Alguns sítios de empresas, como a Asos.com, oferecem um vídeo curto da peça sendo usada por uma modelo. Seria interessante verificar a eficácia deste recurso para dirimir dúvidas quando ao caimento da peça. Infelizmente, este recurso onera a produção do conteúdo dos sítios e nem todas as marcas podem arcar com o custo de fornecê-lo ao usuário ${ }^{14}$.

5. Com base nas informações disponíveis você tem segurança de que o tamanho escolhido está correto?

O Grupo B mostrou mais insegurança do que o Grupo A quanto ao tamanho escolhido, $60 \%$ contra $47 \%$ das voluntárias deram respostas negativas. Mais uma vez as usuárias de desktop/laptop mostraram ter uma melhor compreensão acerca das informações apreendidas. Porém, quase metade das voluntárias do Grupo A não tiveram certeza da escolha do tamanho da peça.

As informações relacionadas às medidas e ao caimento das peças são os pontos mais vulneráveis em relação à compra de roupas on-line. São o que o Lal e Sarvary (1999) denominam de atributos não-digitais de um produto; estão entre as características consideradas mais difíceis de serem comunicadas on-line, tais como a textura, o caimento, o fit and feel (o ajuste e o toque) de um objeto.

Das voluntárias do Grupo B que deram uma resposta afirmativa à pergunta, a justificativa que se destacou foi a utilização de experiências prévias para a escolha do tamanho, 58\% declararam terem-se baseado em seu histórico de compras para escolherem o tamanho. As voluntárias não necessariamente fizeram suas escolhas de tamanhos com base nas informações do sítio, mas fundamentaram-na em suas experiências prévias, oriundas de outras compras e portanto tiveram mais facilidade.

\section{As políticas de troca da loja estão claras? Sim $\square$ Não}

Como forma de diminuir o risco percebido os consumidores buscam garantias tais como comprar de marcas conhecidas ou de empresas que ofereçam

\footnotetext{
${ }^{14}$ Após a realização dos testes verificou-se que algumas marcas comercializadas no sítio da Dafiti começaram a usar videos como recurso para mostrar a peça.
} 
boas políticas de trocas (KOTLER; KELLER, 2016; SOLOMON, 2011). Para a grande maioria das voluntárias dos dois Grupos (67\% do A e $87 \%$ do B) as políticas de troca estavam claras. Parte das voluntárias que deram uma resposta negativa, ou não encontraram as políticas ou não as leram.

Um ponto a destacar é a densidade de informação: o mesmo texto é utilizado tanto no sítio móvel quando no completo. Apesar de não ter surtido um efeito negativo nas voluntárias, seria interessante testar mais a fundo a compreensão do texto e solicitar-lhes que simulassem o processo de troca. No teste de usabilidade elas eram somente solicitadas a acharem as políticas.

7. Geralmente, quando você compra on-line o preço é um fator decisório de compra? Sim $\square$ Não

Como já havia sido indicado na entrevista exploratória e no questionário online (Capítulo 5). O preço é um fator importante para quem compra on-line. O segmento de moda e acessórios do e-commerce brasileiro é líder em número de pedidos, mas não em faturamento (E-BIT, 2017b).

\section{Quais outros fatores influenciam sua decisão de compra?}

Mesmo já terem respondido à pergunta anterior o fator financeiro é o principal influenciador na decisão de compra. Facilidades de pagamento, preço do frete, ofertas e descontos foram citados com bastante frequência, por $25 \%$ das voluntárias.

\section{Como você escolheu o seu tamanho?}

Apenas $13 \%$ das voluntárias utilizaram somente os recursos do sítio da Dafiti para escolherem o seu tamanho ao executarem as tarefas 1 e 2. Este resultado reflete a dificuldade em que os consumidores de e-commerce de vestuário têm para determinarem o seu tamanho utilizando-se das informações apresentadas. Conforme abordado no capítulo 4, a questão do tamanho na indústria do vestuário é um problema mundial. Por um lado estão organizações realizando estudo antropométricos nas populações para serem mais exatos nas tabelas de medidas e estabelecendo normas para a comunicação destas informações e por outro estão as marcas utilizando-se de tabelas próprias para atingirem os seus públicos-alvo. Muitas vezes as tabelas são manipuladas para 
refletirem o vanity sizing, medidas da vaidade, para que os consumidores tenham a falsa impressão de vestirem tamanhos menores em função de uma exigência estética da sociedade (CHUN, 2007; DINIS; VASCONCELOS, 2014).

Essa falta de padronização causa insegurança nos consumidores, e a falta de uma inspeção adequada do produto antes de comprá-lo, como é o caso de vendas on-line, resulta em um alto índice de devoluções (ANDERSON; HANSEN; SIMESTER, 2009) e em consumidores insatisfeitos com as suas compras. Em um mundo altamente globalizado, onde há importação e exportação de produtos, é importante que informações sobre tamanho e caimento sejam mais bem comunicadas.

\section{3.}

\section{Observações gerais}

Além das respostas às perguntas de perfil e do debriefing, dos resultados do AttrakDiff2 ${ }^{\mathrm{TM}}$ e do teste de usabilidade, foi possível observar outros aspectos da interação das usuárias ao realizar as tarefas, listados abaixo:

a) Quando se filtra por tipo de peça, os resultados são bem confusos. Por exemplo, no item camisas tem como resultado bodies e blusas, problema de categorização e AI;

b) No sítio completo o menu superior é ativado por mouseover e por click, dificultando a navegação do usuário;

c) Os itens do menu superior estão muito próximos e por serem ativados por mouseover é necessário estar-se atento a propósito de qual categoria foi ativada. Esta específica falta de atenção isso induziu muitas voluntárias ao erro;

d) Um popup de desconto de $\mathrm{R} \$ 20$ interrompeu as voluntárias diversas vezes no decorrer da realização das tarefas;

e) Houve bastante dúvida quanto à nomenclatura das peças, a maioria das voluntárias não soube distinguir a diferença entre uma blusa e uma camisa por exemplo; 
f) Pessoas mais novas mostraram-se menos pacientes com a demora das respostas do sistema;

g) No sítio completo o filtro do preço não é muito preciso, induzindo as voluntárias ao erro;

h) O FIT FINDER contém um botão “Adicionar ao carrinho", porém o ícone é o de uma sacola, as demais referências no sítio usam a palavra "sacola" e não "carrinho" a falta de consistência pode induzir um usuário ao erro;

i) Por ser um marketplace não há um padrão na apresentação dos produtos;

j) As voluntárias não tinham paciência de esperar as página carregarem até o final;

k) Uma imagem com aparência de link (Figura 7.10) fez as voluntárias tentarem clicar para ter informações sobre os "30 dias para troca e devolução grátis" induzindo-as ao erro;

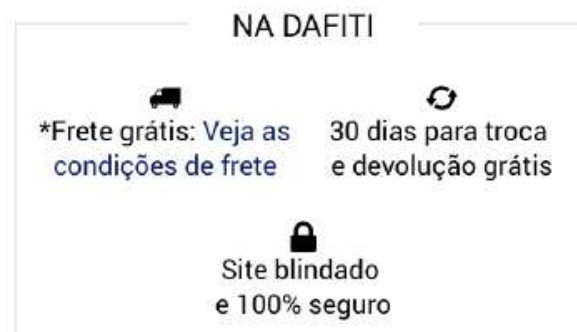

Figura 7.10 - Imagem com aparência de link.

1) O campo de busca não é clicável, é preciso clicar no ícone da lupa para ativá-lo;

m)Na página de Dúvidas Frequentes não raramente as voluntárias clicaram na opção Outras Informações para procurar a tabela/guia de medidas.

\section{4.}

\section{Conclusão}

A presente pesquisa propôs-se a analisar a experiência de compra de peças de vestuário em um determinado sítio de e-commerce, o Dafiti.com.br. De acordo 
com o referencial teórico e o resultado das fases da pesquisa exploratória e descritiva, conclui-se que:

a) A comodidade e fatores financeiros são os principais motivadores para a compra on-line, segundo os resultados da Entrevista Exploratória e o Debriefing;

b) Os principais obstáculos para a compra de peças de vestuário on-line são a inconsistência das medidas e a dificuldade de comunicar informações sobre o caimento;

c) As voluntárias sentiram-se mais inseguras a respeito do caimento do que em relação às medidas da peça;

d) Tocar e manipular o produto ainda é uma necessidade para alguns consumidores;

e) A importância da imagem na apresentação do produto foi comentada pelas

f) voluntárias. A falta de identificação com as modelos das fotos foi um dos fatores que influenciou negativamente a experiência do usuário;

g) Não houve uma diferença significativa na UX dos testes realizados em desktop/laptop comparados àqueles realizados em smartphones;

h) A arquitetura da informação do sítio móvel é menos intuitiva do que no sítio completo, as voluntárias que realizaram os testes em smartphones não tiveram tanta facilidade para encontrar as Políticas de Trocas nem a Tabela/Guia de Tamanhos;

i) Havia menos caminhos disponíveis para se fazer as mesmas tarefas no sítio móvel do que no sítio completo;

j) As estratégias omnichannel são cada vez mais adotadas por varejistas à medida que os canais on-line e off-line diferem em sua capacidade de fornecer informações sobre produtos;

k) A transposição direta de projetos de sítios completos para sítios móveis dificulta o acesso à informação e portanto ao processo de compra; 
1) As voluntárias recorreram com bastante frequência à ferramenta de busca no sítio da Dafiti, porém esta só oferecia a pesquisa sobre produtos e não considerava erros de grafia nem abrangia termos similares;

m)A busca no sítio deve considerar erros ortográficos e termos similares;

n) Nem todos filtros oferecidos eram relevantes e de fácil compreensão, havia um excesso de filtros de tamanhos. No sítio móvel essa preocupação deve ser maior ainda;

o) Notou-se uma falta de conhecimento técnico acerca dos produtos de vestuário. Durante o teste houve confusão quanto à nomenclatura das peças (blusa e camisa), aos métodos de medição do corpo e quanto à composição e tipos de tecido;

p) Realizar uma devolução ou troca é visto como uma tarefa que envolve um alto grau de dificuldade, mesmo tendo sido a tarefa que foi cumprida com mais facilidade;

q) No momento da escolha de tamanho, as voluntárias não recorriam com muita frequência às informações fornecidas pelo sítio, utilizavam-se de dados obtidos de experiências passadas de compras, mesmo as off-line. Isto acontecia por não confiarem nas informações apresentadas, ou por não as entenderem ou até mesmo por não as acharem;

r) Houve voluntárias que declararam terem escolhido um tamanho maior para certificarem-se que a peça iria caber;

s) No sítio móvel o botão de acesso à página de "Ajuda" está denominado de "Dúvidas";

t) A questão da padronização dos tamanhos é um assunto controverso, os especialistas são contra uma padronização, acreditam que as marcas devam desenvolver modelagens de acordo com o seu público-alvo;

u) O grupo B teve um número maior de pessoas que não cumpriram a tarefa. 


\section{Análise geral da pesquisa}

De acordo com os problemas de pesquisa, observa-se atualmente dificuldades por parte dos usuários no processo de compra de peças de vestuário. Esta dificuldade não se dá somente durante a interação mas é percebida mesmo antes, e afeta a expectativa do usuário influenciando sua UX e não está atrelada à versão do sítio, se é móvel ou completo. A maior barreira entre os mundos real e digital no que tange peças de vestuário, está na falta de contato físico prévio com o produto, impedindo o usuário de fazer uma inspeção completa. Um dos motivos que fortalece esta barreira e intensifica a insegurança dos usuários é a incerteza quanto ao ajuste e caimento das peças, sua vestibilidade. Atualmente no Brasil, não existe uma padronização dos tamanhos praticada pela indústria e tampouco há uma forma eficiente de comunicar este e outros aspectos ao usuário. Atributos como as medidas, caimento e textura de tecido são dificilmente comunicados digitalmente.

Os capítulos teóricos: 2, 3 e 4, foram primordiais para sucitar as questões abordadas nos capítulos práticos (6 e 7), fornecendo a base na qual pautou-se a escolha e elaboração dos métodos e técnicas utilizados. Ademais, formaram o embasamento teórico para o desenvolvimento da conclusão e das diretrizes formuladas no item seguinte deste capítulo.

Para mais, no capítulo 4 foram discutidos os possíveis motivos que resultam em uma dificuldade de se haver uma consistência nos tamanhos de peças de vestuário. As razões vão da dificuldade de padronizar-se por causa da variedade nas formas dos corpos até às questões mercadológicas (vanity sizing). Segundo os especialistas (capítulo 5) deve permitir-se que as marcas tenham liberdade para criar modelagens de acordo com o seu público-alvo, mas é preciso ter transparência na comunicação destes critérios. A visão dos usuários difere da dos especialistas 
(capítulo 5 e 6): a falta de consistência nas tabelas de medidas lhes causa insegurança e pode dissuadi-los de não realizar compras on-line.

Ainda no capítulo 4 foi abordado o estudo antropométrico do SenaiCetiqt cujo objetivo é realizar uma varredura no País a fim de traçar os diferentes tipos físicos existentes e contribuir para que a indústria nacional produza artigos, não só de vestuário, mais adequados aos brasileiros.

Os pressupostos da pesquisa, foram confirmados. Sobre o primeiro pressuposto, "A falta de conhecimento sobre o usuário e de seus modelos mentais resultam em projetos de interface confusos", notou-se durante o teste de usabilidade que houve momentos da interação em que o projeto do sítio testado mostrou-se pouco intuitivo, induzindo as voluntárias ao erro. $\mathrm{O}$ segundo pressuposto: "As informações fornecidas sobre o produto de vestuário (por exemplo: modelagem, materiais, dimensões, etc.) são insuficientes ou superficiais e dificultam a tomada de decisão do consumidor, aumentando a barreira entre o real e o virtual, impactando a satisfação percebida", foi o maior obstáculo para a decisão de compra. Impossibiltadas de fazer uma inspeção prévia do produto ao comprar on-line é primordial o acesso ao máximo de informações para dar suporte ao processo de tomada de decisão do usuário. Nem todos os produtos disponíveis no sítio da Dafiti tinham descrições completas em suas páginas. O terceiro e último pressuposto: "A transposição direta dos sítios completos (destinados a desktops) e a falta de hierarquização e priorização das informações ao projetar sítios móveis dificultam o processo de compra e resultam em um sítio com um baixo grau de usabilidade", também provou-se verdadeiro. As voluntárias tiveram mais dificuldade de compreender textos longos, como os da Políticas de Trocas e Devoluções. Ademais a arquitetura da informação era menos intuitiva. Porém estas dificuldades não afetaram significativamente a UX, como mostrou o resultado do questionário AttrakDiff2 ${ }^{\mathrm{TM}}$.

A partir dos dados obtidos, tanto os objetivos gerais quando os específicos: "elaborar diretrizes que possam contribuir com o design de sítios de e-commerce de vestuário feminino mais eficientes, eficazes e satisfatórios, proporcionando uma experiência do usuário positiva; identificar os pontos de maior dúvida no que tange à usabilidade de sítios de e-commerce de vestuário; analisar os principais obstáculos com os quais os usuários deparam-se, quando da tomada de decisão da 
compra on-line; e comparar a experiência do usuário ao usar um smartphone com a sua experiência ao usar um desktop" foram atingidos.

A intenção das diretrizes a seguir são de sintentizar o foi pesquisado e respondido quanto aos problemas da pesquisa.

\section{1.}

\section{Diretrizes}

Com base nos resultados das fases da pesquisa exploratória e descritiva fazse uma lista de recomendações. O teste de usabilidade não foi realizado para abordar questões particulares do sítio analisado. Observou-se-lhe com o intuito de verificar como é realizado o processo de compra de peças de roupas em ecommerce principalmente como se dá a escolha do tamanho, do tecido, do caimento da peça e a interpretação das informações que oferece ao usuário. Porém algumas questões de usabilidade surgiram no decorrer da realização dos testes.

Estas recomendações, ou diretrizes baseiam-se nos objetivos da usabilidade propostos por Brangier e Barcenilla (2003) e nos princípios e diretrizes de usabilidade abordados no capítulo 2 e foram agrupadas de forma similar a utilizada por Miranda (2004).

Navegação

- Agrupar ferramentas que possuam funções similares, como os links: Atendimento e Ajuda; o agrupamento considera a localização e o formato para indicar as relações entre os diversos itens apresentados, e se eles pertencem ou não a uma mesma classe de itens ;

- Indicar de forma explícita a ativação de filtros, principalmente no sítio móvel;

- Oferecer filtros que sejam relevantes, o excesso dificulta a navegação dos usuários;

- Diferenciar os links das imagens;

- Nomear categorias usando palavras que não confundam os usuários e ser consistente;

\section{Busca do produto (Página de Produtos)}

- Oferecer uma busca global no sítio e não somente de produtos;

- A busca deve ser mais abrangente e aceitar sinônimos e erros de grafia; 
- Ao utilizar filtros o sistema só deve retornar com resultados que sejam relevantes à busca do usuário;

- O filtro de preço deve permitir o preenchimento do valor desejado;

\section{Página de apresentação do produto (Página do produto)}

- Educar o usuário quanto às características técnicas dos produtos, principalmente acerca das medidas, da composição dos tecidos e da nomenclatura das peças, por meio de um glossário de fácil acesso;

- Dar acesso de forma fácil a um link para o glossário, no qual estarão todos os termos técnicos seguidos de explicação (MIRANDA, 2004);

- Fornecer acesso fácil a um link para as tabelas de medidas específicas à peça de roupa que o usuário está pesquisando e para tabelas de medidas gerais para fins de referencia;

- Fornecer acesso fácil às políticas de trocas e devoluções, preferencialmente que estejam listadas na página de apresentação do produto sem obrigar o usuário a acessar uma outra página e ter de interromper a tarefa de compra;

- Auxiliar o usuário a entender quais são os critérios de medidas adotados por cada marca;

- Fornecer instruções de fácil acesso sobre como o usuário deve se medir; - Caso o sítio opte por oferecer um sistema para auxiliar o usuário a escolher seu tamanho, como o FIT FINDER, também deve incluir as tabelas de medidas em centímetros;

- As fotos dos produtos devem mostrar mais detalhes, quando possível utilizar vídeos que ilustram melhor o caimento das peças;

- As fotos dos produto devem despertar mais identificação no usuário;

- Dar preferência à fotos tiradas com o produto vestido em pessoas;

- Padronizar o modelo das tabelas de medidas (consistência);

- Padronizar a apresentação dos produtos (fotos, informações, dados técnicos); e

- Fornecer as medidas da modelo e o tamanho da peça que ela estiver vestindo para fins comparativos.

Gerais:

- Oferecer garantias (por exemplo: troca facilitada); 
- Dar acesso de forma fácil a um link para as políticas de trocas e devoluções;

- Os textos informativos e instrutivos (como no caso das instruções para efetuar Trocas e Devoluções) devem ser: escritos considerando o dispositivo utilizado; fáceis de achar, breves; centrados na tarefa do usuário e claros quanto às etapas que o usuário deve executar;

- As palavras "Sacola" e "Carrinho" são utilizadas para fazer referência à página em que os itens selecionados ficam salvos (Figura 8.1), também é utilizado um ícone de uma sacola, este é um caso de falta de consistência nos padrões adotados pelo sítio, os usuários não se devem se perguntar se palavras, ações ou situações diferentes possuem o mesmo significado. A um objeto deve ser associado um significado e, inversamente, a um significado será associado um objeto e um só (NIELSEN, 1993);

- Ser transparente quanto aos custos logísticos, o usuário não deve saber quanto vai pagar de frete somente no momento do checkout; e

- Otimizar o sítio para que seja navegável utilizando uma rede 3G ou wi-fi.

\section{Sítio móvel}

- Facilitar o acesso à página de "Ajuda" no sítio móvel, um produto deve ser projetado de modo que as funcionalidades e as informações mais importantes estejam facilmente acessíveis ao usuário;

- Otimizar a navegação considerando o uso de redes $2 \mathrm{G}$ e $3 \mathrm{G}$, diminuindo tempos de downloads e do carregamento das páginas;

- Tornar o acesso às Políticas de Trocas e Devoluções mais acessível via sítio móvel;

- Facilitar a navegação no smartphone indicando mais explicitamente a localização do usuário;

- A forma como se apresentam as tabelas de medidas deve ser diferenciada para o uso no smartphone;

- A forma como se apresentam as informações sobre caimento deve ser diferenciada para o uso no smartphone; e

- Aumentar as áreas sensíveis ao toque nos sítios móveis. 


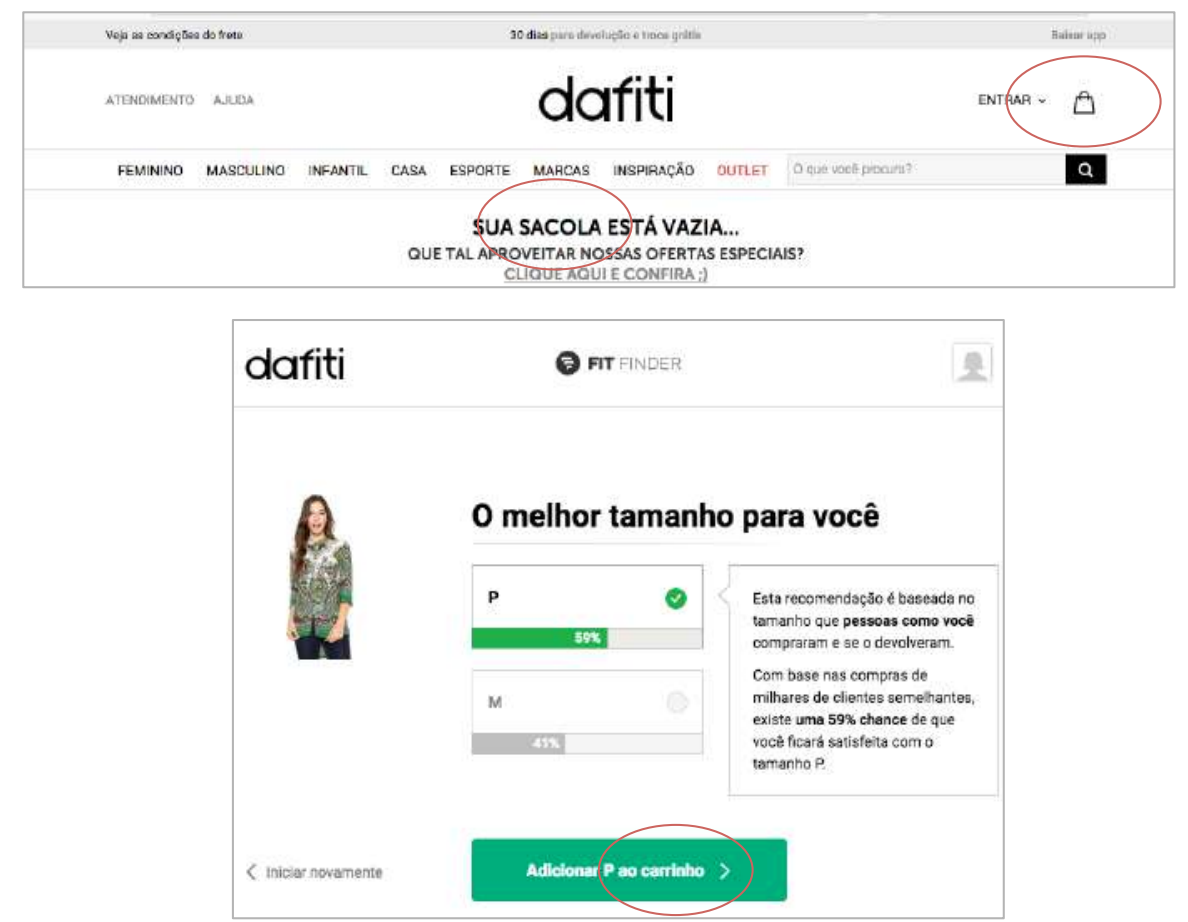

Figura 8.1 - Inconsistência de informação. Fonte: Elaborado pela autora.

As diretrizes aqui apresentadas são sugestões pautadas na observação de 60 voluntárias ao realizar tarefas no sítio da Dafiti. Lembra-se que não é possível projetar uma experiência, somente projetar em função dela. Afirmar que um grupo de recomendações sempre produzirá determinadas emoções, pode ser que se prometa mais do que poderá ser cumprido (HASSENZAHL, 2004).

\section{2.}

\section{Experiência desktop/laptop versus experiência móvel}

Os resultados da fase da pesquisa descritiva não indicaram uma diferença significativa entre a UX e usabilidade entre os sítios móveis e completos. Com exceção às perguntas: "Você sente-se segura em relação as informações sobre o caimento da peça?" e "Com base nas informações disponíveis você tem segurança de que o tamanho escolhido está correto?" em que houve resultados consideravelmente diversos ao testar as duas versões do sítio da Dafiti. Em razão do tamanho da tela a quantidade de informações apresentadas de uma vez ao usuário smartphone é menor. Sua carga cognitiva para processar esta informação é maior e o número de vezes necessário para rolar a página também é maior, demandando mais de sua memória de curto prazo (NIELSEN; BUDIU, 2014). 


\section{3.}

\section{Desdobramentos da pesquisa}

Nesta dissertação foram medidas as UX em desktops/laptops e smartphones, um possível desdobramento seria ampliar esse escopo aos tablets e às lojas físicas.

Outro desdobramento é observar como a UX desenvolve-se ao longo do tempo. Seria necessário realizar o mesmo teste com as mesmas pessoas após um período de tempo para averiguar como a UX evoluiu. Existem poucos estudos sobre esta particular preocupação da autora desta dissertação.

Além dos desdobramentos supracitados:

Os testes de usabilidade poderiam ser realizados com homens, ou com mulheres de outros estados do Brasil e ser estendido ao aplicativo da Dafiti;

As voluntárias determinavam em qual dispositivo que iriam realizar o teste de usabilidade, seria interessante trocar os grupos para verificar a UX;

Adicionar à tarefa 3 a realização do processo de devolução e não somente descobrir onde encontra-se esta informação no sítio; e

Testar uma outra técnica para medir a UX e comparar os resultados com os obtidos por meio do questionário AttrakDiff2 ${ }^{\mathrm{TM}}$. 


\section{Referências bibliográficas}

ABIT (Associação Brasileira da Indústria Têxtil). Cartilha de costurabilidade, uso e conservação de tecidos para decoração. São Paulo: ABIT, 2011.

ABIT (Associação Brasileira da Indústria Têxtil). Perfil do Setor. São Paulo, 2017. Disponível em: <http://www.abit.org.br/cont/perfil-do-setor>. Acesso em: 11 out. $2017 \mathrm{a}$.

ABIT (Associação Brasileira da Indústria Têxtil). Setor têxtil e de confecção aponta sinais positivos para 2017. ABIT.org.br Seção Notícias. São Paulo, jan. 2017. Disponível em: <http://www.abit.org.br/noticias/setor-textil-e-deconfeccao-aponta-sinais-positivos-para-2017>. Acesso em: 11 out. 2017 b.

ABNT (Associação Brasileira de Normas Técnicas). NBR 13377: medidas do corpo humano para vestuário - padrões referenciais. Rio de Janeiro: ABNT, 1995.

NBR 9241-11: requisitos ergonômicos para trabalho de escritório com computadores. Parte 11: Orientações sobre usabilidade. Rio de Janeiro: ABNT, 2002 . ABNT, 2004.

NBR 15127: corpo humano - definição de medidas. Rio de Janeiro:

NBR 15800: vestuário - referência de medidas do corpo humano vestibilidade de roupas para bebê e infanto-juvenil. Rio de Janeiro, 2009.

NBR 16060: vestuário - referência de medidas do corpo humano vestibilidade para homens corpo tipo normal, atlético e especial. Rio de Janeiro, 2012.

ABRAVEST. Vestuário e têxtis alcançaram produção de R \$ 131 bilhões em 2015. ABRAVEST.org.br. Seção Blog IEMI. set. 2016. Disponível em: $<$ http://abravest.org.br/site/blog-iemi-28-09-2016/>. Acesso em: 11 out. 2017.

AGNI, E. Don Norman e seus princípios de design. UX.blog. [São Paulo], jun. 2015. Disponível em: <http://www.uxdesign.blog.br/user-experience/donnorman-principios-design/> . Acesso em: 12 fev. 2016.

AJIBOLA, A. S.; GOOSEN, L. Missed opportunities in mobile e-commerce usability. International Journal of Scientific \& Engineering Research v. 5, n. 6, p. 954-956, 2014. 
ALDRICH, W. Fabrics and Pattern Cutting. $1^{\text {st }}$ ed. West Sussex: John Wileys \& Sons, 2013.

ALDRICH, W. History of sizing systems and ready-to-wear garments. In: ASHDOWN, S. P. (Org.). Sizing in clothing: developing effective sizing systems for ready-to-wear clothing. Cambridge: Woodhead Publishing, 2007. p. $1-56$.

ANDRADE, A. M. M. Como preparar trabalhos para cursos de pósgraduação: noções práticas. 5. Ed. São Paulo: Atlas, 2002.

ALEXA.COM. Top sites in Brazil. Alexa.com. Disponível em: $<$ http://www.alexa.com>. Acesso em: 24 set. 2016.

ALVES, A. S.; GRUBER, C. Estudo comparativo entre tabelas de medidas femininas para modelagem. In: VII Colóquio de Moda, 2011, Maringá. Anais... Colóquio de Moda 2011. Disponível em: < http://www.coloquiomoda.com.br/anais_ant/7-coloquio-de-modagt13_comunicacaooral.php> Acesso em: 25 out. 2017.

ANDERSON, E. T.; HANSEN, K.; SIMESTER, D. The Option Value of Returns: Theory and Empirical Evidence. Marketing Science, [Maryland], v. 28, n. 3, p. 405-423, 2009.

ARAÚJO, M. Tecnologia do vestuário. Lisboa: Fundação Calouste Gulbenkian, 1996.

ATLAS. E-commerce radar moda e Acessórios $1^{\circ}$ semestre 2017: panorama do mercado de moda e acessórios no e-commerce brasileiro. São Paulo: Atlas, 2017. Disponível em: < http://hotsite.neoatlas.com.br/ecommerce-radar>. Acesso em 20 aug. 2017.

AUDACES. Enfesto de Tecido: como escolher o melhor tipo para o seu segmento? Audaces.com, [Florianópolis], dez. 2014. Seção. Falando de Tecido. Disponível em: $<\mathrm{http}: / / \mathrm{www}$.audaces.com/enfesto-de-tecido-como-escolher-omelhor-tipo-para-o-seu-segmento/>. Acesso em: 30 set. 2017.

BABIN, B. J.; DARDEN, W. R.; GRIFFIN, M. Work and/or fun: Utilitarian shopping value. Journal of Consumer Research, Chicago, v. 20, n. 4, p. 644 $657,1994$.

BAE, S.; LEE, T. Gender differences in consumers' perception of online consumer reviews. Electronic Commerce Research, [S.I.]. v. 11, n. 2, p. 201214, 2011.

BARBOSA, S. D. J.; SILVA, B. S. Interação Humano-Computador. Rio de Janeiro: Elsevier, 2010.

BARDIN, L. Análise de conteúdo. Tradução de Luís Antero Reto, Augusto Pinheiro. São Paulo: Edições 70, 2011. 
BARNARD, M. Moda e comunicação. Tradução Lúcia Olinto. Rio de Janeiro: Rocco, 2003.

BARNUM, C. M. Usability Testing Essentials: ready, set...test! Burlington: Morgan Kaufman, 2011.

BASTIEN, J. M. C.; SCAPIN, D. L. Ergonomic criteria for the evaluation of human-computer interfaces. Rapport techinique de INRIA. Behaviour \& Information Technology, London, v. 16, n. 4/5, p. 220-231, 1997.

BASTOS, S. F. et al. SizeBR: o estudo antropomético brasileiro. $4^{\text {th }}$ International Conference and Exhibition on 3D Body Scanning Technologies, Long Beach, 2013. Disponível em: <http://senaicetiqt.com/sizebr-o-estudoantropometrico-brasileiro/> Acesso em: 30 set. 2017.

BASTOS, S. F.; SABRÁ, F. G. A forma do corpo da mulher brasileira. $5^{\text {th }}$ International Conference and Exhibition on 3D Body Scanning Technologies, 2014. Disponível em: <http://arquivos.portaldaindustria.com.br/app/conteudo 18/2014/07/10/6822/A_forma_do_corpo_da_mulher_brasileira.pdf?r=0.8716071 8317>. Acesso em: 30 set. 2017.

BAXTER, K.; COURAGE, C.; CAINE, K. Understanding your users: a practical guide to user requirements, methods, tools, and techniques. San Francisco: Morgan Kaufman Publishers, 2015.

BEDFORD, A. Trustworthiness in Web Design: 4 Credibility Factors. NNGroup, Fremont, mar. 2017. Seção Articles. Disponível em: $<$ https://www.nngroup.com/articles/trustworthy-design>. Acesso em: 20 out. 2017.

BELL, D. Localização (ainda) é tudo: como vender mais usando a influência do mundo real sobre os hábitos de compra na internet. Tradução Bruno Alexander. São Paulo: HSM do Brasil, 2016.

BEVAN, N.; CARTER, J.; HARKER, S. Iso 9241-11 revised: What have we learnt about usability since 1998? Lecture Notes in Computer Science (including subseries Lecture Notes in Artificial Intelligence and Lecture Notes in Bioinformatics), v. 9169, p. 143-151, 2015.

BEZERRA, A. C. M. Ouvindo os profissionais envolvidos e as crianças: um estudo de caso. 2010. 300 f. Tese (Doutorado em Design)- Programa de Pósgraduação em Design do Departamento de Artes e Design, Pontifícia Universidade Católica do Rio de Janeiro, Rio de Janeiro, 2010.

BIBLIOTECA DANTE MOREIRA LEITE. O que revisão da literatura, Universidade de São Paulo, Instituto de Psicologia. São Paulo, [19--?]. Disponível em: <http://www.ip.usp.br/portal/images/biblioteca/revisao.pdf $>$. Acesso em: 12 abr. 2016.

BIBLIOTECA PROF. PAULO DE CARVALHO MATTOS. Tipos de revisão de literatura, Faculdades de Ciências Agronômicas, UNESP, Campus de Botucatu. 
Botucatu, 2015. Disponível em: $<$ http://www.fca.unesp.br/Home/Biblioteca/tiposde-evisao-de-literatura.pdf>. Acesso em: 12 abr. 2016.

BLÁZQUEZ, M. Fashion Shopping in Multichannel Retail: The Role of Technology in Enhancing the Customer Experience. International Journal of Electronic Commerce, v. 18, n. 4, p. 97-116, 2014.

BRANDÃO, G. Curso de corte e costura Gil Brandão. 3. ed. São Paulo: Editora Três, 1967.

BRANGIER, E.; BARCENILLA, J. Concevoir un produit facile à utiliser: Adapter les technologies à l'homme. Paris: Éditions d'Organisation, 2003.

BRANSON, D. H.; NAM, J. Materials and sizing. In: ASHDOWN, S. P. (Org.). Sizing in clothing: developing effective sizing systems for ready-to-wear clothing. 1. ed. Cambridge: Woodhead Publishing, 2007. p. 264-276.

BREHM, L. M. S. Contribuição para a Classificação e Descrição dos tecidos de seda 100\% empregados em vestuário. 2011. 143 f. Dissertação (Metrado em Design)- Universidade Federal do Rio Grande do Sul - UFRS, Porto Alegre, 2011.

CARDOSO, G. C. Avaliação de experiência do usuário durante o desenvolvimento de um aplicativo social móvel. 2013. 169 f. Dissertação (Mestrado em Design Gráfico)- Universidade Federal de Santa Catarina, Florianópolis, 2013.

CARROLL, J. M.; OLSON, J. R. Mental models in human-computer interaction: Research issues about what the user of software knows. Washington D.C.: National Academy Press, 1987.

CASTILHO, Kathia. Do corpo à moda: exercícios de uma prática estética. In: CASTILHO, K.; GALVÃO, D. (Ed.). A moda do corpo o corpo da moda. São Paulo: Editora Esfera, 2002. p. 59-72.

CASTRO, A. A. Revisão sistemática e meta-análise. São Paulo, 2001. Disponível em: <http://metodologia.org/wp-content/uploads/2010/08/meta1.pdf $>$. Acesso em: 12 abr. 2016.

CAVAlHEIRO, R. M; SILVA, R. L. A. Moldes femininos: noções básicas. 1. ed. Rio de Janeiro: Senac Nacional, 2003.

CHAMMAS, A.; QUARESMA, M.; MONT'ALVÃO, C. Um enfoque ergonômico sobre a metodologia de design de interfaces digitais para dispositivos móveis. Arcos Design, Rio de Janeiro, v. 7, n. 2, p. 145-171, 2013.

CHAN, S.; FANG, X. Usability Issues in Mobile Commerce. In: AMERICAS CONFERENCE ON INFORMATION SYSTEMS, 7., 2001, Boston. Anais... Boston AMCIS 2001 Proceedings. 88, 2001. p. 439-442.

CHAN, S. S. et al. Usability for mobile commerce across multiple form factors. Journal of Electronic Commerce Research, v. 3, n. 3, p. 187-199, 2002. 
CHAN, S. S.; FANG, X. Mobile Commerce and Usability. In: LIM, E.-P.; SIAU, K. (Eds.). Advances in Mobile Commerce technologies. Hershey: Idea Group Publishing, 2003. p. 236-256.

CHAPANIS, A. Human factors in systems engineering. New York: John Wileys \& Sons, 1996.

CHATAignieR, G. Fio a fio. Tecidos, moda e linguagem. Rio de Janeiro: Estação das Letras, 2006.

CHIZZOTTI, A. Pesquisa em ciências humanas e sociais. São Paulo: Cortez, 2000 .

CHUN, Jongsuk. Comunication of sizing and fit. In: ASHDOWN, S. P. (Org.). Sizing in clothing: developing effective sizing systems for ready-to-wear clothing. 1. ed. Cambridge: Woodhead Publishing, 2007. p. 220-243.

CLARK, J. Tapworthy: Designing Great iPhone Apps. Sebastopol: O'Reilly Media, 2010.

COMSCORE. Global digital future in focus. $1^{\text {st }}$ ed. Reston: ComScore, out. 2016. Disponível em: < https://www.comscore.com/Insights/Presentations-andWhitepapers/2016/2016-Global-Digital-Future-in-Focus $>$. Acesso em: 20 nov. 2017.

COMSCORE. Key Measures Retail Apparel. Rio de Janeiro, 2016.

CONVERSION. Relatório Conversion do e-commerce brasileiro 2016. São Paulo: Conversion, 2016. Disponível em: $<$ http://lp.conversion.com.br/relatorioconversion-do-e-commerce-brasileiro-2016>. Acesso em: 7 abr. 2016.

COOPER, A. et al. About Face: the essentials of interaction design. 4. ed. Indianapolis: Wiley Publishing Inc., 2014.

COSTA, A. C. R.; ROCHA, É. R. P. Panorama da Cadeia Produtiva Têxtil e de Confecções e a Questão da Inovação. BNDES Setrorial. Rio de Janeiro, n. 29, p 159-202, mar. 2009.

CUMMING, Valerie; CUNNINGTON, C. Willet; CUNNINGTON, Phylis. The dictionary of fashion history. 1. ed. Oxford: Berg Publishers, 2010.

CYBIS, W.; HOLTZ, A.; FAUST, R. Ergonomia e usabilidade. São Paulo: Novatec, 2010.

Sobre a Dafiti. dafiti.com.br São Paulo, [201-?]. Disponível em: $<$ https://www.dafiti.com.br/institucional/\#sobre-a-dafiti>. Acesso em: 12 out. 2017.

DAVIS, F. Fashion, culture and identity. Chicago: The University of Chicago Press, 1992. 
DELFINO, L. C. A importância das bases de modelagem para desenvolvimento de uma coleção. 2014. 85 f. Trabalho de Conclusão de Curso (Especialização)-Universidade do Extremo Sul Catarinense - UNESC, Criciúma, 2014.

DIAPER, D. Understanding Task Analysis for Human-Computer Interaction. In: DIAPER, D.; STANTON, N. A. (Eds.). The handbook of task analysis for human-computer interaction. London: Taylor \& Francis e-Library, 2008. p. 547.

DINIS, P. M.; VASCONCElOS, A. F. C. Modelagem. In: SABRÁ, F. (Org.). Modelagem: tecnologia em produção de vestuário. 2. ed. Rio de Janeiro: SENAI CETIQT, 2014. p. 54-125.

DUH, H. B.; TAN, G. C. B.; CHEN, V. H. Usability evaluation for mobile device: a comparison of laboratory and field tests. In: Mobile HCI, 2006, Helsinki. Anais... Helsinki: MobileHCI'06, 2006. p. 181-186.

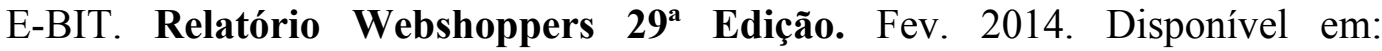
$<$ http://www.ebit.com.br/webshoppers>. Acesso em: 20 mai. 2016.

Relatório Webshoppers 31 ${ }^{\mathbf{a}}$ Edição. Fev. 2015. Disponível em: $<$ http://www.ebit.com.br/webshoppers $>$. Acesso em: 21 jun. 2015.

Relatório Webshoppers 33 ${ }^{a}$ Edição. Fev. 2016. Disponível em: <http://www.ebit.com.br/webshoppers>. Acesso em: 05 abr. 2016.

Relatório Webshoppers 35a Edição. São Paulo: E-Bit, fev. 2017a. Disponível em: $<$ http://www.ebit.com.br/webshoppers $>$.

Relatório Webshoppers 36 $^{\mathrm{a}}$ Edição. Ago. 2017b. Disponível em:

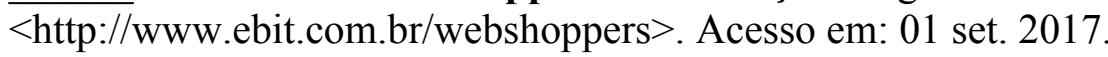

ECOMMERCE FOUNDATION. Global B2C e-commerce report 2016. Amsterdam: Ecommerce Foundation, 2016. Disponível em: $<\mathrm{http}$ ://www.ecommercefoundation.org/reports>. Acesso em: 27 out. 2017.

FLAHERTY, K. Seamless in the omnichannel user experience. NNGroup, Fremont, mar. 2017. Seção Articles. Disponível em: <https://www.nngroup.com /articles/seamless-cross-channel/>. Acesso em: 26 ago. 2017.

GERSAK, J. Wearing comfort using body motion analysis. In: GUPTA, D.; ZAKARIA, N. (Orgs.). Anthropometry, apparel sizing and design. Cambridge: Woodhead Publishing, 2014. p. 320-333.

GERSTNER, L. V. Who says elephants can't dance: leading a great enterprise through dramatic change. New York: Harper Business, 2002.

GIBSON, J. J. The Ecological Approach to Visual Perception. Boston: Houghton Mifflin, 1979.

GIL, A. C. Como elaborar projeto de pesquisa. 4. ed. São Paulo: Atlas, 2002. 
GOOGLE. The new multi-screen world: understanding cross-platform consumer behavior. Santa Clara: 2012. Disponível em: $<$ https://www.thinkwithgoogle.com/ advertising-channels/mobile/the-new-multiscreen-world-study/>. Acesso em: 28 abr. 2016.

GRANDJEAN, E. Manual de ergonomia: Adaptando o trabalho ao homem. 4. ed. Porto Alegre: Bookman, 1998.

HANSEN, W. J. User engineering principles for interactive systems. Fall Joint Computer Conference, v. 39, p. 523-532, 1971.

HARTSON, R.; PYLA, P. S. The UX book, process and guidelines for ensuring a quality user experience. Waltham: Elsevier, 2012.

AttrakDiff : Ein Fragebogen zur Messung wahrgenommener hedonischer und pragmatischer Qualität. Mensch \& Computer 2003: Interaktion in Bewegung, Sttutgart, p. 187-196, 2003b.

HASSENZAHL, M. Emotions can be quite ephemeral; we cannot design them. Interactions, v. 11, n. 5, p. 46, 2004.

Hedonic, emotional, and experiential perspectives on product quality. In: GHAOUI, C. (ORG.). Encyclopedia of human computer interaction. Hershey: Idea Group Reference, 2006. p. 266-268.

. The hedonic/pragmatic model of user experience. (E. Law et al., Eds.). Towards a UX Manifesto - COST294-MAUSE Affiliated Workshop. Anais... Lancaster: COST294-MAUSE, 2007.

HASSENZAHL, M.; DIEFENBACH, S.; GÖRITZ, A. Needs, affect, and interactive products: facets of user experience. Interacting with Computers, v. 22 , n. 5, p. 353-362, 2010.

HASSENZAHL, M. et al. Experience-Oriented and Product-Oriented Evaluation: Psychological Need Fulfillment, Positive Affect, and Product Perception. International Journal of Human-Computer Interaction, n. 31, p. 530-544, 2015.

HEINRICH, D. P. Modelagem: ferramenta competitiva para a indústria da moda. Porto Alegre: SEBRAE/RS: FEEVALE, 2007a.

Modelagem \& Técnicas de Interpretação para Confecção Industrial. 2. ed. Novo Hamburgo: Feevale, $2007 \mathrm{~b}$.

HELLMAN, M.; RÖNKKÖ, K. Controlling User Experience through Policing in the Software Development Process. In: I-USED 2008. Anais... Pisa: 2008.

HIRSCHMAN, E. C.; HOLBROOK, M. B. Hedonic consumption: Emerging concepts, methods and propositions. Journal of Marketing, v. 46, n. 3, p. 92$101,1982$. 
IIDA, I.; BUARQUE, L. Ergonomia: projeto e produção. 3. ed. São Paulo: Blucher, 2016.

INSTITUTO BRASILEIRO DE GEOGRAFIA E ESTATÍSTICA. PNAD 2013. Rio de Janeiro: IBGE, 2014. Disponível em: <http://downloads.ibge.gov.br/ downloads_estatisticas.htm>. Acesso em: 22 jun. 2015.

INOSTROZA, R. et al. Usability heuristics for touchscreen-based mobile devices. Proceedings of the 9th International Conference on Information Technology, ITNG 2012, n. 2241, p. 662-667, 2012.

ISO (International Standard Organization). ISO 9241-210:210. Ergonomics of human-system interaction- Part 210: human-centered design for interactive systems. Genebra: International Standard Organization. 2010.

JEDDI, S. et al. Consumer behavior and Consumer buying decision process. International Journal of Business and Behavioral Sciences, v. 3, n. 5, p. 20 23, 2013.

JOHNSON, J. Designing with the Mind in Mind: Simple Guide to Understanding User Interface Design Rules. Burlington: Morgan Kaufman, 2010.

JOHNSON, P. Usability and Mobility: Interactions on the move. (C. Johnson, Ed.). First workshop on human-computer interaction with mobile devices. Anais... Glasgow: 1998

JORDAN, P. W. Designing pleasurable products: an introduction to the new human factors. Boca Raton: CRC Press, 2000.

Introduction to Usability. London: Taylor and Francis, 2001.

JUANEDA-AYENSA, E.; MOSQUERA, A.; MURILLO, Y. S. Omnichannel customer behavior: Key drivers of technology acceptance and use and their effects on purchase intention. Frontiers in Psychology, v. 7, n. Jul., p. 1-11, 2016.

KATAWETAWARAKS, C.; WANG, C. L. Online shopper behavior: influences of online shopping decision. Asian Journal of Business Research. v. 1, n. 2, p. 66-74, 2011.

KIM, D.; BENBASAT, I. Trust-Assuring Arguments in B2C E-commerce: Impact of Content, Source, and Price on Trust. Journal of Management Information Systems, v. 26, n. 3, p. 175-206, 2009.

KOTLER, P. Administração de Marketing. 10. ed. São Paulo: Prentice Hall, 2000.

KOTLER, P.; KELLER, K. L. Marketing management. $15^{\text {th }}$ Global ed. Boston: Pearson, 2016.

KPMG. The truth about online consumers: 2017 The Global online consumer report. New $\quad$ York: 2017. Disponível em: < 
https://assets.kpmg.com/content/dam/kpmg/xx/pdf/2017/01/the-truth-aboutonline-consumers.pdf $>$ Acesso em: 16 ago. 2017.

KRUG, S. Don't make me think! A common sense approach to web usability. $2^{\text {nd }}$ ed. Berkeley: New Riders, 2006.

KUNIAVSKY, M. Smart Things, Ubiquitous Computing User Experience Design. Burlington: Morgan Kaufman, 2010.

LABAT, K. L. Sizing and standardization. In: ASHDOWN, S. P. (Org.). Sizing in clothing: developing effective sizing systems for ready-to-wear clothing. $1^{\text {th }}$. ed. Cambridge: Woodhead Publishing, 2007. p. 88-108.

LAL, R.; SARVARY, M. When and How is the Internet Likely to Decrease Price Competition? Marketing Science, v. 18, n. 4, p. 485-503, 1999.

LAUDON, K. C.; TRAVER, C. G. E-commerce 2016: business, technology, society. $12^{\text {th }}$ Global ed. Boston: Pearson, 2016.

LEE, Jeong Yim et al. Comparison of body shape between USA and Korean women. International Journal of Clothing Science and Technology, v. 19, n. 5, p. 374-391, 2007. Disponível em: <http://www.emeraldinsight.com/doi/abs/ 10.1108/09556220710819555>. Acesso em: 27 out. 2017.

LEITE, A. S.; VELLOSO, M. D. Desenho técnico de roupa feminina. 1. ed. Rio de Janeiro: Senac Nacional, 2004.

LEVY, J. UX Strategy: how to devise innovative digital products that people want. $1^{\text {st }}$ ed. Sebastopol: O’Reilly, 2015.

LIRA, R. P. J.; TAVARES, T. Aprendendo pela interação: uma experiência com o uso de interfaces tangíveis e realidade aumentada voltada para curvas de níveis. $6^{0}$ Simpósio Hipertextos e Tecnologias na Educação $2^{\circ}$ Colóquio Internacional de Educação com Tecnologias. Anais...Recife: 2015

MAGRATH, V.; MCCORMICK, H. Marketing design elements of mobile fashion retail apps. Journal of Fashion Marketing and Management, v. 17, n. 1, p. 115-134, 2013.

MASHAPA, J.; VAN GREUNEN, D. User experience evaluation metrics for usable accounting tools. Proceedings of the 2010 Annual Research Conference of the South African Institute of Computer Scientists and Information Technologists on - SAICSIT '10, p. 170-181, 2010.

MANDEL, T. The Elements of the User Interface. New York: John Wileys \& Sons, 1997.

MARCONI, M. A.; LAKATOS, E. M. Técnicas de pesquisa. 4. ed. São Paulo: Atlas, 1999.

; _ Fundamentos de metodologia científica. 5. ed. São Paulo:

Atlas, 2003. 
MARTINS, A. V. S.; LOPES, L. A. O processamento têxtil. In: SABRÁ, F. (Org.). Modelagem: tecnologia em produção de vestuário. 2. ed. Rio de Janeiro: SENAI CETIQT, 2014. p. 18-35.

MATIAS, M A. Análise da tabela de medidas femininas, criada pela ABRAVEST, junto às indústrias de confecções de Criciúma. 2009. $56 \mathrm{f}$. Trabalho de Conclusão de Curso (Especialização)- Universidade do Extremo Sul Catarinense, Criciuma, 2009.

MCKINSEY \& COMPANY. The State of fashion 2017. London, 2017.

MCKNIGHT, D. H.; CHOUDHURY, V. Distrust and Trust in B2C ECommerce: Do they differ? Proceedings of the 8th international conference on Electronic commerce: ICEC'06, p. 482-491, 2006.

MEMÓRIA, F. Design para a internet: projetando a experiência perfeita. 1. ed. Rio de Janeiro: Elsevier, 2005.

MENDOZA, Adrian. Mobile User Experience: patterns to make sense of it all. Waltham: Elsevier, 2014.

MILL, D. Content is king: writing and editing online. $1^{\text {st }}$ ed. Burlington: Elsevier, 2005.

MIRANDA, F. M. P. Estudo ergonômico de websites de comércio eletrônico: seleção do produto pelo usuário no processo de compra. 2004. 313 f. Dissertação (Mestrado em Design)- Programa de Pós-graduação em Design do Departamento de Artes e Design, Pontifícia Universidade Católica do Rio de Janeiro, Rio de Janeiro, 2005.

MOCZARNY, I. M.; DE VILLERS, M. R.; VAN BILJON, J. A. How can usability contribute to user experience? A study in the domain of e-commerce. Saicsit 12, p. 216-225, 2012.

MOLICH, R.; NIELSEN, J. Improving a human-computer dialogue. Communications of the ACM, v. 33, n. 3, p. 338-348, 1990.

MOLICH, R. Usable web design. $1^{\text {st }}$ ed. Copenhagen: Nyt Teknisk Forlag, 2007.

MORAES, A. Ergonomia, ergodesign e usabilidade: algumas histórias, precursores: divergências e convergências. Ergodesign e HCI, v. 1, n. 1, p. 1-9, 2013.

MORAES, A. DE; MONT'ALVÃO, C. Ergonomia: Conceitos e aplicações. 4 ed. ampliada Rio de Janeiro: 2AB, 2009.

MUCCHIELLI, R. O questionário na pesquisa psicossocial. Tradução de Luiz Lorenzo Rivera; Sílvia Magaldi. Revisão de Monica Stahel Monteiro da Silva. 1. ed. São Paulo: Martins Fontes, 1979.

NIELSEN, J. Usability Engineering. San Francisco: Morgan Kaufman, 1993. 
Riders, 2000.

Designing Web Usability: the practice of simplicity. Indianapolis: New

Mobile UX Sharpens Usability Guidelines. NNGroup, Fremont, jan.

2012. Disponível em: $<$ http://www.nngroup.com/articles/usability-101introduction-to-usability/>. Acesso em: 10 maio 2015.

IA task failures remain costly. NNGroup, Fremont, abr. 2009. Disponível em: $<$ https://www.nngroup.com/articles/ia-task-failures-remaincostly/>. Acesso em: 1 maio. 2016.

Bridging the designer-user gap. NNGroup, Fremont, mar. 2008. Disponível em: $<$ https://www.nngroup.com/articles/bridging-the-designer-usergap/>. Acesso em: 30 jan. 2017.

Ecommerce usability improvements. NNGroup, Fremont, out. 2011. Disponível em: <https://www.nngroup.com/articles/ecommerce-improvements/>. Acesso em: 11 out. 2017.

NIELSEN, J.; BUDIU, R. Usabilidade móvel. Rio de Janeiro: Elsevier, 2014.

NIELSEN, J.; FARRELL, S.; SNYDER, C.; MOLICH, R. E-commerce User Experience: Category Pages, Nielsen Norman Group, 2000(a).

;

\& Registration, Nielsen Norman Group, 2000(b).

E-Commerce User Experience: Checkout ; ___ . $\quad$; _ E-Commerce User Experience: Product

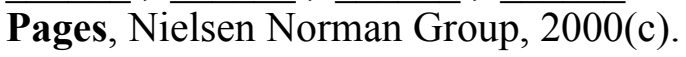

Nielsen Norman Group, 2000(d).

. E-Commerce user experience: Trust.

NORMAN, D. A. Emotional Design: why we love (or hate) everyday things. New York: Basic Books, 2004. Books, 2013.

The Design of Everyday Things. $2^{\text {nd }}$ ed. rev. e aum. New York: Basic

NORMAN, D. A.; NIELSEN, J. The definition of User Experience. NNGroup, Fremont, [200?]. Disponível em: $<$ https://www.nngroup.com/articles/definitionuser-experience/>. Acesso em: 15 out. 2016.

MERHOLZ. P. Peter in Conversation with Don Norman About UX \& Innovation. Adaptive Path, 13 dez. 2007. Disponível em: $<$ http://adaptivepath.org/ideas/e000862/>. Acesso em: 4 dez. 2016.

OLIVEIRA, A. C. M. A. Por uma semiótica da moda. In: CASTILHO, K.; GALVÃO, D. (Ed.). A moda do corpo o corpo da moda. 1. ed. São Paulo: Editora Esfera, 2002. p. 126-134. 
OXFORD DICTIONARIES. Oxford English Dictionary. 7. ed. Oxford: Oxford University Press, 2012.

OZOK, A. A.; WEI, J. An empirical comparison of consumer usability preferences in online shopping using stationary and mobile devices: Results from a college student population. Electronic Commerce Research, v. 10, n. 2, p. $111-137,2010$.

PADOVANI, S.; SCHLEMMER, A.; SCARIOT, C. A. Usabilidade e user experience, usabilidade versus user experience, usabilidade em user experience? Uma discussão teórico-metodológica sobre comunalidades e diferenças. $\mathbf{1 2}^{\mathbf{0}}$ Ergodesign: $12^{\circ}$ Congresso Internacional de Ergonomia e Usabilidade de Interfaces Humano-Computador., 2012.

PAI, M. et al. Clinical Research Methods Systematic reviews and meta-analyses: An illustrated, step-by-step guide. The National Medical Journal of India, v. 17, n. 2, p. 86-95, 2004.

PALMIERI, I. M.; RODRIGUES, A. L. V.; SOUZA, P. M. O caimento como fator determinante na seleção de materiais. In: $4^{\circ}$ Congresso Brasileiro de Iniciação Científica de Moda, 2017. Anais... UNESP Bauru 2017.

PARDO, A. Millennials são mobile. Proxxima, [São Paulo], 2016. Disponível em:

$<$ http://www.proxxima.com.br/mob/mobile/noticias?path=/home/mobile/2016

/03/Millennials-sao-mobile>. Acesso em: 5 mar. 2016

PASCUAL-MIGUEL， F. J.; AGUDO-PEREGRINA， Á. F.; CHAPARROPELÁEZ, J. Influences of gender and product type on online purchasing. Journal of Business Research, v. 68, n. 7, p. 1550-1556, 2015.

PEREIRA, G. S. Curso têxtil em malharia e confecção módulo 2: Introdução à tecnologia têxtil. Araranguá: CEFET-SC, 2008. Disponível em: $<$ https://wiki.ifsc.edu.br/mediawiki/images/7/7d/Apostila_tecnologia.pdf $>$.

Acesso em: 19 dez. 2017.

PEREIRA, R.; BEZERRA, L. Vestibilidade: transposição teórica e metodológica com base na ABNT NBR 9241-11 / 210. In: 13 COLÓQUIO DE MODA, 2017, Bauru. Anais... Colóquio de Moda 2017. Disponível em: $<$ http://www.coloquiomoda.com.br/anais/anais/13-Coloquio-de-

Moda_2017/GT/gt_6/gt_6_VESTIBILIDADE.pdf>. Acesso em: 28 out. 2017.

PHAN, D. Mobile-first Indexing. Google Webmaster Central Blog. [Mountain View], 2016. Disponível em: <https://webmasters.googleblog.com/2016/11/ mobile-first-indexing.html>. Acesso em: 10 nov. 2017.

PHEASANT, S. Bodyspace: Anthropometry, ergonomics, and the design of work. $2^{\text {nd }}$ ed. London: Taylor and Francis, 2003.

PREECE, J.; ROGERS, Y.; SHARP, H. Interaction design: beyond humancomputer interaction. $4^{\text {th }}$ ed. West Sussex: John Wileys \& Sons, 2015. 
QIN, Z. Introduction to e-commerce. Beijing: Tsinghua University Press and Springer, 2009.

QUARESMA, M. M. R. Avaliação da usabilidade de sistemas de informação disponíveis em automóveis: Um estudo ergonômico de sistemas de navegação GPS. 2010. 340 f. Tese (Doutorado em Design)- Programa de Pós-graduação em Design do Departamento de Artes e Design, Pontifícia Universidade Católica do Rio de Janeiro, Rio de Janeiro, 2010.

RAUPP, F. M.; BEUREN, I. M. Metodologia da pesquisa aplicável às Ciências Sociais. In: I. M. Beuren (Ed.), Como Elaborar Trabalhos Monográficos em Contabilidade: Teoria e Prática . 3 ed. São Paulo: Atlas, 2006. p. 76-97

ROBERTO, C.; AVELAR, S. Somos todos Severinos: moda e identidade. In: $11^{\circ}$ COLÓQUIO DE MODA, 2015, Curitiba. Anais... Colóquio de Moda 2015. Disponível em: < http://www.coloquiomoda.com.br/anais_ant/anais/11-Coloquiode-Moda_2015/COMUNICACAO-ORAL/CO-EIXO3-CULTURA/CO-3SOMOS-TODOS-SEVERINOS.pdf>. Acesso em: 14 set. 2017.

ROBIER, J. UX Redefined: Winning and keeping customers with enhanced usability and user experience. Switerland: Springer International Publishing, 2016.

ROLLIM, C.; RADICETTI, E. Modelagem industrial feminina: construção das bases, técnicas e interpretações de modelagem. 1. ed. Rio de Janeiro: Edição do Autor, 2009.

ROSA, L. Vestuário Industrializado: Uso da Ergonomia nas Fases de Gerência de Produto, Criação, Modelagem e Prototipagem. 2011. 175 f. Tese (Doutorado em Design)- Programa de Pós-graduação em Design do Departamento de Artes e Design, Pontifícia Universidade Católica do Rio de Janeiro, Rio de Janeiro, 2011.

ROTO, Virpi et al. User Experience White Paper: Bringing clarity to the concept of user experience. Seminar on Demarcating User Experience, p. 12, 2010. Disponível em: <www.allaboutux.org/uxwhitepaper>. Acesso em: 30 mai. 2016.

RUBIN, J.; CHISNELL, D. Handbook Of Usability Testing: How to plan, design and conduct effective tests. 2. ed. Indianapolis: Wiley Publishing Inc., 2008 .

SAFFER, D. Designing Gestural Interfaces: Touchscreens and Interactive Devices. Sebastopol: O’Reilly Media, 2008.

SANDERS, M. S.; MCCORMICK, E. J. Human factors in engineering and design. $7^{\text {th }}$ ed. New York: McGraw-Hill, 1993.

SANTA ROSA, J. G.; MORAES, A. DE. Avaliação e projeto no Design de Interfaces. 2. ed. Teresópolis: 2AB, 2012. 
SCHNEIDER, G. P. Electronic Commerce. $9^{\text {th }}$ ed. Boston: Course Technology, Cengage Learning, 2011.

SEBRAE-RJ. Boletim SEBRAE: como driblar a falta de padronização nas medidas do vestuário nacional. Rio de Janeiro: SEBRAE-RJ, nov. 2014. Disponível em: $<$ https://www.sebraeinteligenciasetorial.com.br/produtos/relatorio s-de-inteligencia/nova-padronizacao-de-tamanho-para-roupas-

femininas/54b4ff1bd371b27a00cdbbe6>. Acesso em: 21 jun. 2015.

SEBRAE-RJ. Relatório Trimestral. Rio de Janeiro: SEBRAE-RJ, jan. 2015. Disponível em: $<$ https://www.sebraeinteligenciasetorial.com.br/produtos/relatorio s-de-inteligencia/nova-padronizacao-de-tamanho-para-roupas-

femininas/54b4ff1bd371b27a00cdbbe6>.

SEBRAE-RJ. Relatório de Inteligência. Rio de Janeiro: SEBRAE-RJ, nov. 2015. Disponível em: $<$ https://sebraeinteligenciasetorial.com.br/setores/moda/relatoriosde-inteligencia $>$. Acesso em: 6 abr. 2016.

SENAI-CETIQT. Conheça nossas pesquisas. SENAI-CETIQT. Disponível em: $<$ http://www.portaldaindustria.com.br/senai/canais/senai-cetiqt/estudos-epesquisas/conheca-nossas-pesquisas/>. Acesso em: 27 out. 2017.

SEVERINO, A. J. Metodologia do trabalho científico. 21. ed. São Paulo: Cortez, 2000.

SHNEIDERMAN, B.; PLAISANT, C. Designing The User Interface. $4^{\text {th }}$ ed. Boston: Pearson, 2005.

SIAU, K.; LIM, E.-P.; SEN, Z. Mobile Commerce: Current States and Future Trends. In: LIM, E.-P.; SIAU, K. (Eds.). Advances in Mobile Commerce technologies. 1. ed. Hershey: Idea Group Publishing, 2003. p. 12-30.

SILVEIRA, I. Tecnologia da Modelagem I. Florianópolis: Universidade do Estado de Santa Catarina . (UDESC), 2003.

SILVEIRA, I. Um modelo para capacitação dos instrutores do sistema CAD para vestuário e dos modelistas, com foco na gestão do conhecimento. 2011. 305 f. Tese (Doutorado em Design)-Programa de Pós-graduação em Design do Departamento de Artes e Design, Pontifícia Universidade Católica do Rio de Janeiro, Rio de Janeiro, Rio de Janeiro, 2011.

SINTEX. Exportações brasileira de produtos têxteis. Blumenau: Sintex, out. 2017. Disponível em: <http://www.sintex.org.br/estatistica/brasil-exportacao>. Acesso em: 25 out. 2017.

Indústria têxtil de Santa Catarina, perspectivas e desafios para o crescimento. Blumenau: SINTEX, jun. 2015. Disponível em: $<$ http://sintex.org.br/arquivos/249_ap_sintex-2015_final.pdf $>$. Acesso em: 11 out. 2017.

SMITH, B. R.; CHATFIELD, V.; UEMURA, O. IBM iSeries e-business Handbook: A V5R1 Technology and Product Reference. Rochester: IBM, 2001. 
Disponível em: <https://www.redbooks.ibm.com/redbooks/pdfs/sg246711.pdf>. Acesso em: 11 out. 2017.

SOLOMON, M. R. Comportamento do Consumidor: Comprando, possuindo, sendo. 9. ed. Porto Alegre: Bookman, 2011.

SONDEREGGER, A.; SCHMUTZ, S.; SAUER, J. The influence of age in usability testing. Applied Ergonomics, v. 52, p. 291-300, 2016.

STEELE, V. Encyclopedia of clothing and fashion. Detroit: Thompson Gale, 2005. v. 3

STIBEL, J. Mental models and online consumer behaviour. Behaviour \& Information Technology, v. 24, n. 2, p. 147-150, 2005.

SUN, X.; MAY, A. A comparison of field-based and lab-based experiments to evaluate user experience of personalised mobile devices. Advances in HumanComputer Interaction, v. 2013, 2013.

THE NIELSEN COMPANY. Global connected commerce report: what's in store for online grocery shopping. New York: THE NIELSEN COMPANY. Disponível em: <http://www.nielsen.com/us/en/insights/reports/2017/whats-instore-for-online-grocery-shopping.html>. Acesso em: 7 mar. 2017.

TURBAN, E. et al. Eletronic commerce: a managerial and social networks perspective. $8^{\text {th }}$ ed. New York: Springer International Publishing, 2015.

VÄÄNÄNEN-VAINIO-MATTILA, K.; RUUSKA, S. User Needs for Mobile Communication Devices: Requirements Gathering and Analysis through Contextual Inquiry. (C. Johnson, Ed.). First workshop on human-computer interaction with mobile devices. Anais...Glasgow: 1998.

VITOR, S.; NERY, M. D.; MOREIRA, S. V. A padronização da modelagem como forma de dinamizar as vendas on-line de calças jeans. In: XXXVI Encontro Nacional de Engenharia de Producão. Anais... João Pessoa, 2016.

WEBER, R. P. Basic content analysis. 2. ed. Newbury Park: Sage Publications, 1990.

WROBLEWSKI, Luke. Mobile First. New York: A Book Apart, 2011.

YU, N.; KONG, J. User experience with web browsing on small screens: Experimental investigations of mobile-page interface design and homepage design for news websites. Information Sciences, v. 330, p. 427-443, 2016.

ZARUR, C; LUQUES, I. Confusão entre tamanhos de roupas está com os dias contados. O Globo, Rio de Janeiro, 16 out. 2017. Disponível em: $<$ https://oglobo.globo.com/economia/defesa-do-consumidor/confusao-entretamanhos-de-roupas-esta-com-os-dias-contados-1-21950553>. Acesso em: 27 out. 2017. 


\section{Apêndice 1}

Materiais do questionário on-line 


\section{Questionário on-line}

\section{Compras online}

Olá, muito prazer!

Meu nome é Carolina e sou aluna do mestrado em design da PUC-Rio, onde faço parte da equipe do LEUI - Laboratório de Ergodesign e Usabilidade de Interfaces. Estou recrutando participantes para uma pesquisa que consiste na avaliação da usabilidade (facilidade de uso) de sites acessados por meio de telefones celulares, para tornar as compras via internet mais fáceis para os usuários.

Serão executadas rápidas entrevistas com cada participante, enquanto executam tarefas determinadas, irei recolher informações sobre como estas pessoas interagem com as páginas navegadas. Todos os dados coletados serão transformados em recomendações ergonômicas para melhorar o site estudado.

Importante ressaltar: não pretendo, em nenhum momento, testar as habilidades dos participantes em relação a interface estudada (site). Desejo apenas reunir informações sobre a maneira como as pessoas utilizam esses sites.

As declarações de cada participante serão tratadas de forma confidencial. A apresentação dos resultados será feita de maneira a não permitir a identificação das pessoas envolvidas.

Caso você tenha o interesse de participar desta pesquisa, por favor, preencha o questionário a seguir. Clique nas respostas escolhidas para marcar sua opção.

Ao continuar você concorda em disponibilizar informações anônimas para fins acadêmicos tais como: artigos, aulas, apresentações em simpósios ou congressos relacionados ao tema. Para receber a copia do Termo de Consentimento, abaixo, coloque seu email no campo "Comentários".

TERMO DE CONSENTIMENTO LIVRE E ESCLARECIDO

O Sr. (a) está sendo convidado (a) como voluntário (a) a participar da pesquisa "Compras Online". Esta é uma pesquisa realizada no Laboratório de Ergodesign e Usabilidade de Interfaces da PUC-Rio.

Qualquer dúvida a respeito dos procedimentos, dos resultados e/ou de assuntos relacionados à pesquisa será esclarecida pela aluna pesquisadora Carolina Marianna Bozz Faya e/ou por sua orientadora Cláudia Mont'Alvão, no telefone (21) 3527-1594 ou através dos emails: cmontalvao@puc-rio.br ou ergonomiapuc@gmail.com.

O objetivo da pesquisa é obter informações de como usuários interagem com interfaces de sítios de comércio eletrônico de vestuário.

Para este estudo adotaremos os seguintes procedimentos em 2 (DUAS etapas). A primeira etapa consiste da aplicação de um questionário, com informações sobre seus hábitos de consumo online, além de dados demográficos. A segunda etapa será uma entrevista rápida enquanto o entrevistado realiza tarefas determinadas, serão recolhidas informações de como estas pessoas interagem com as páginas navegadas.

BENEFÍCIOS: A presente pesquisa busca contribuir para tornar o uso de sítios de comércio eletrônico mais fácil.

RISCOS: por se tratar de uma metodologia cuja técnica pauta-se em um questionário e levantamento de dados demográficos, a mesma é considerada com possibilidade quase nula de riscos para o entrevistado. Em caráter remoto, pois, serão adotados os procedimentos para resguardar a identidade dos entrevistados, pode esse sentir algum 


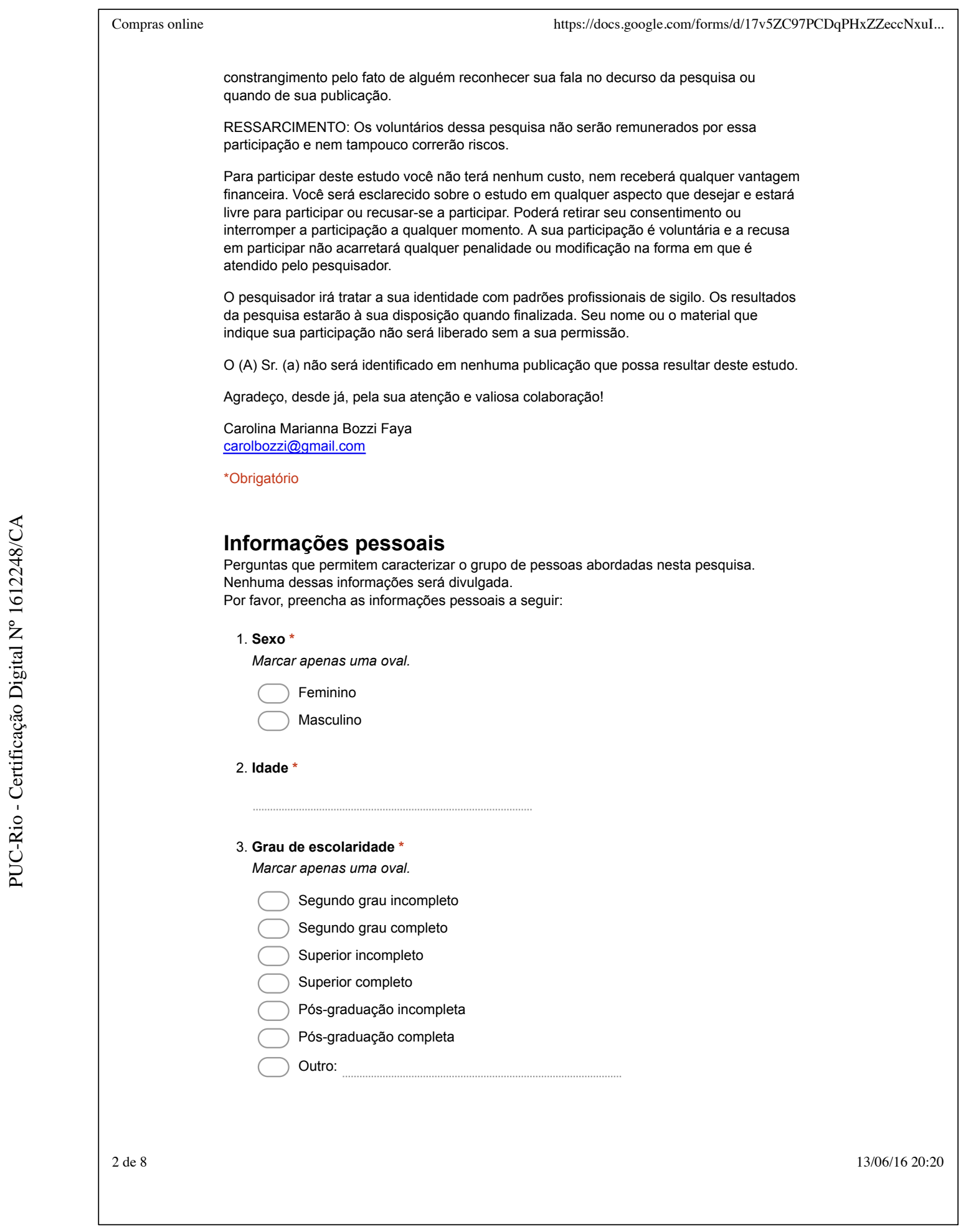




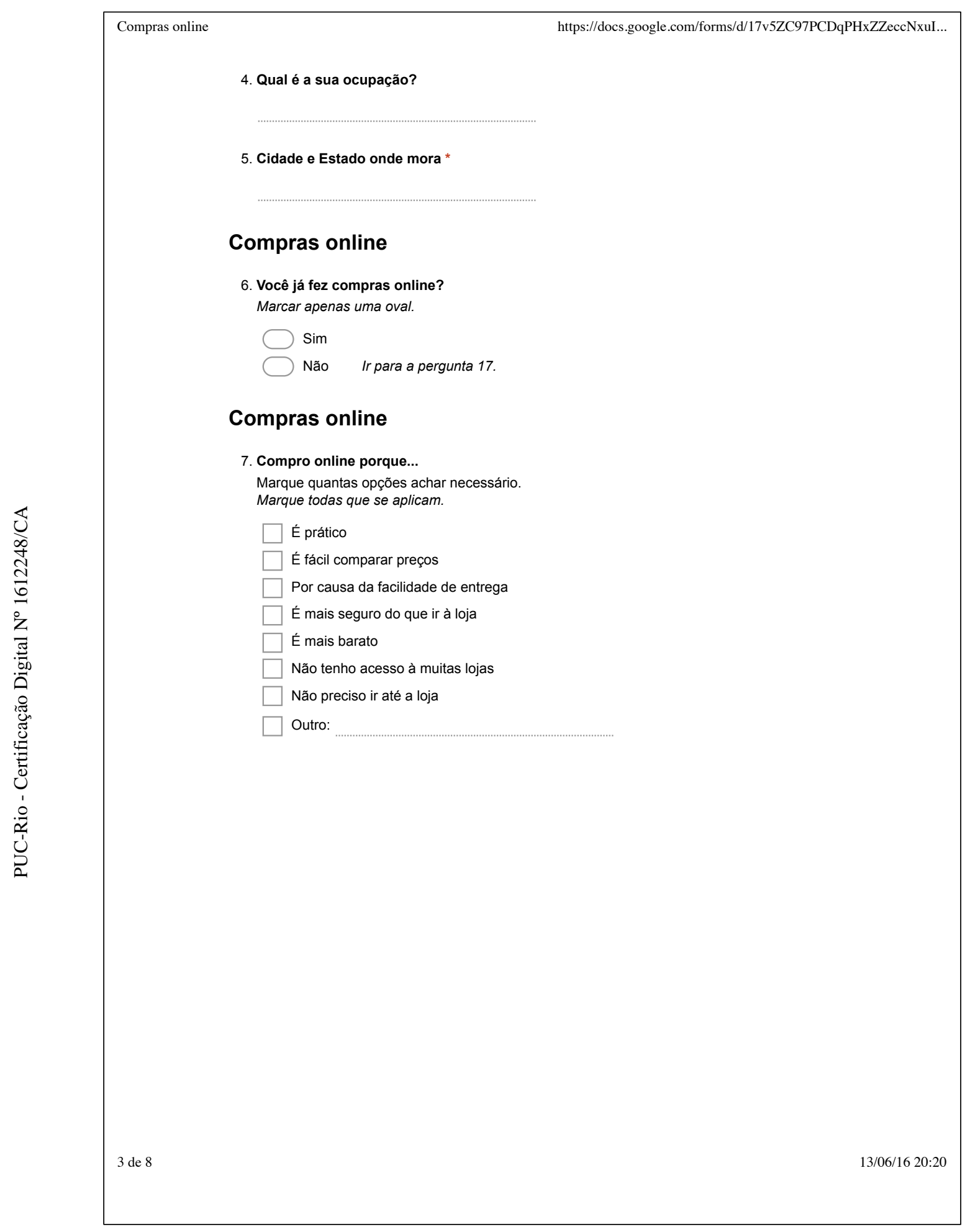




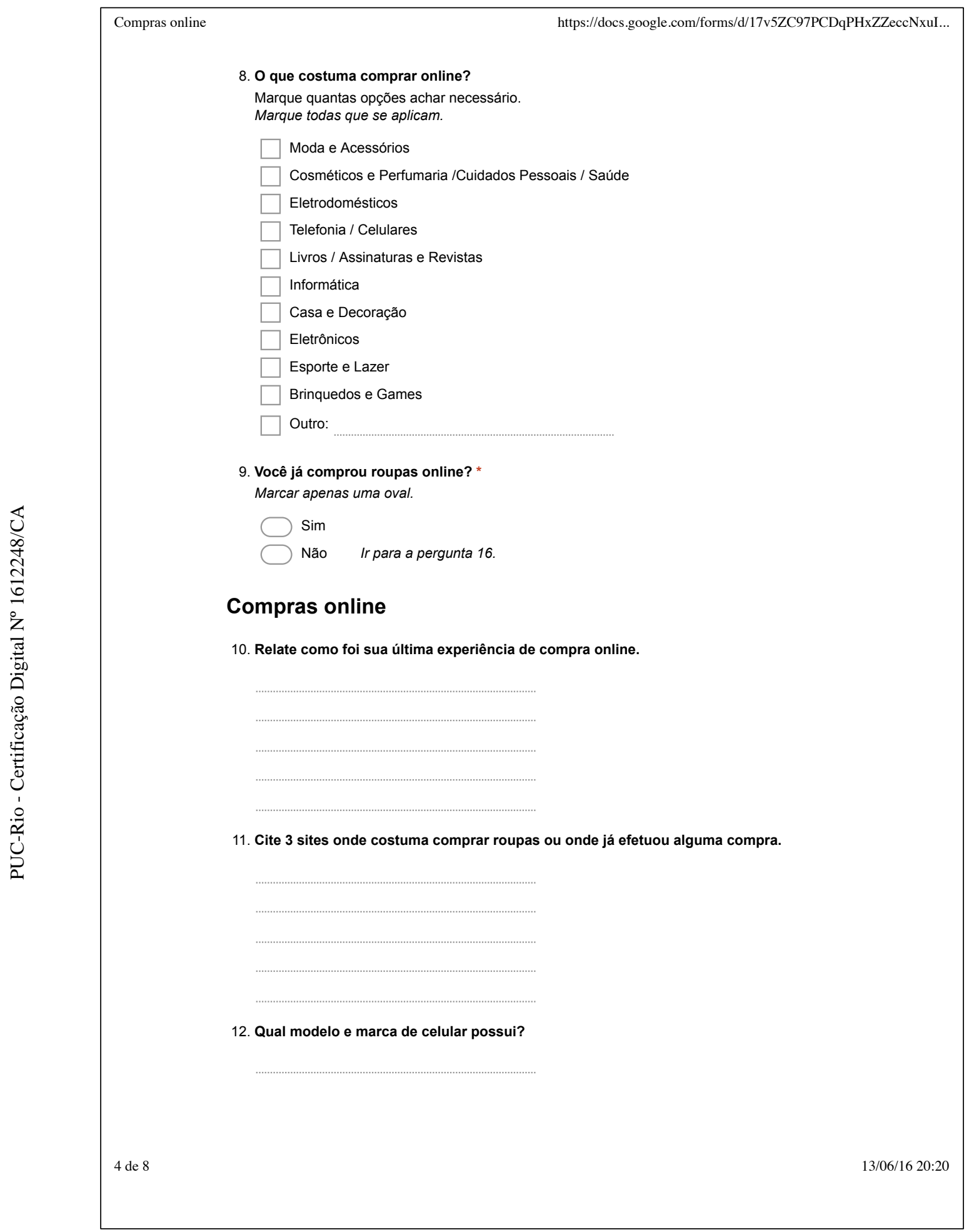




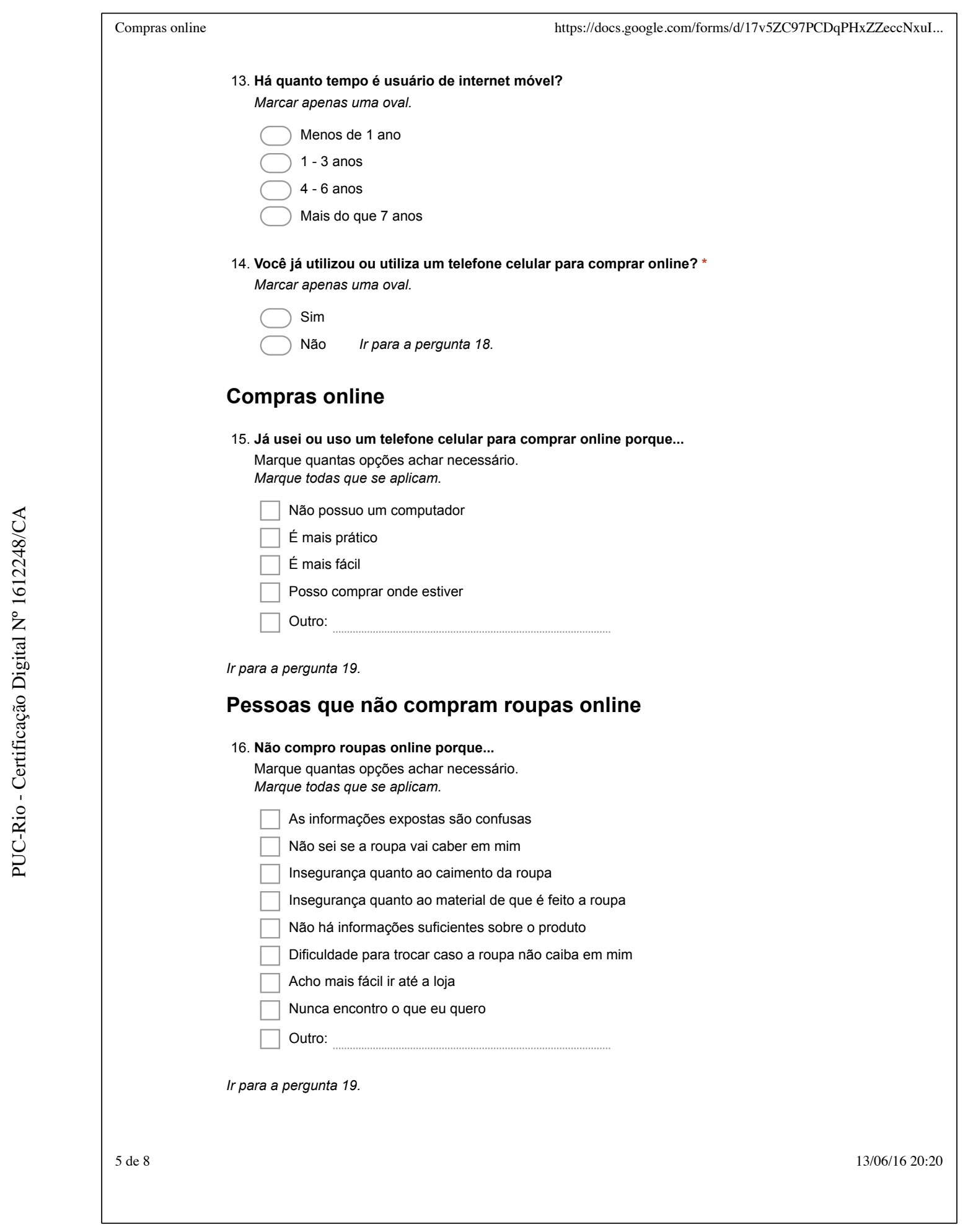




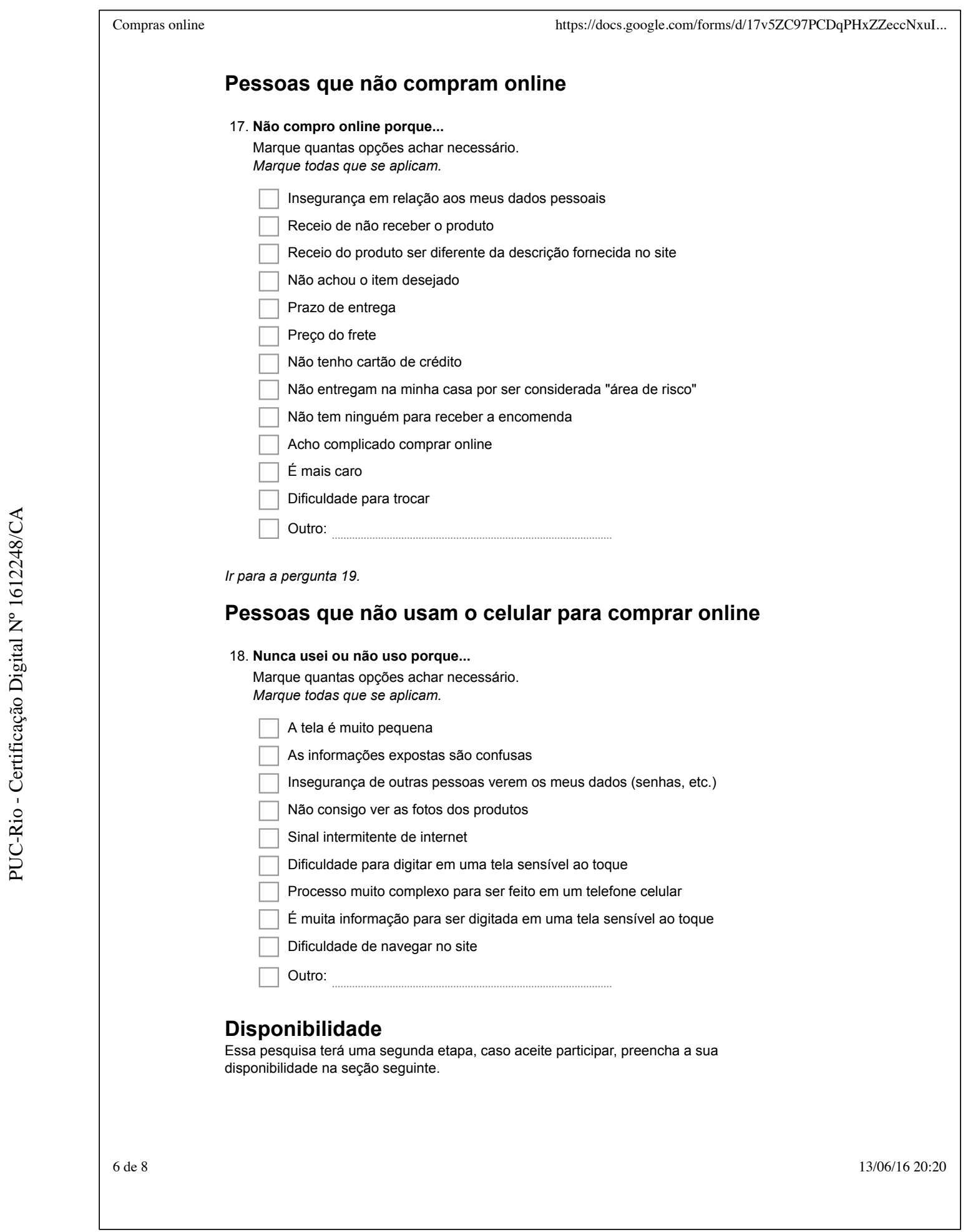




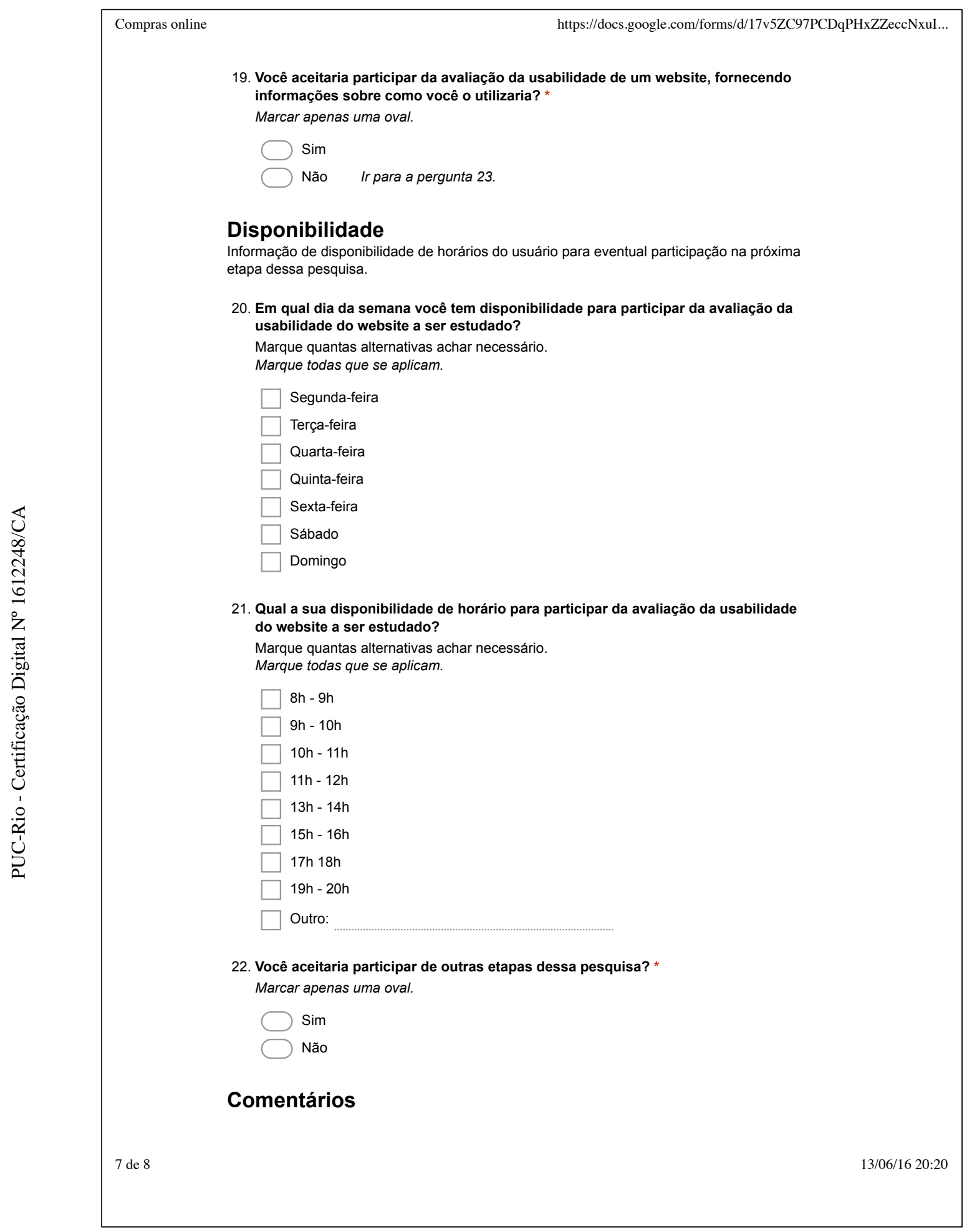




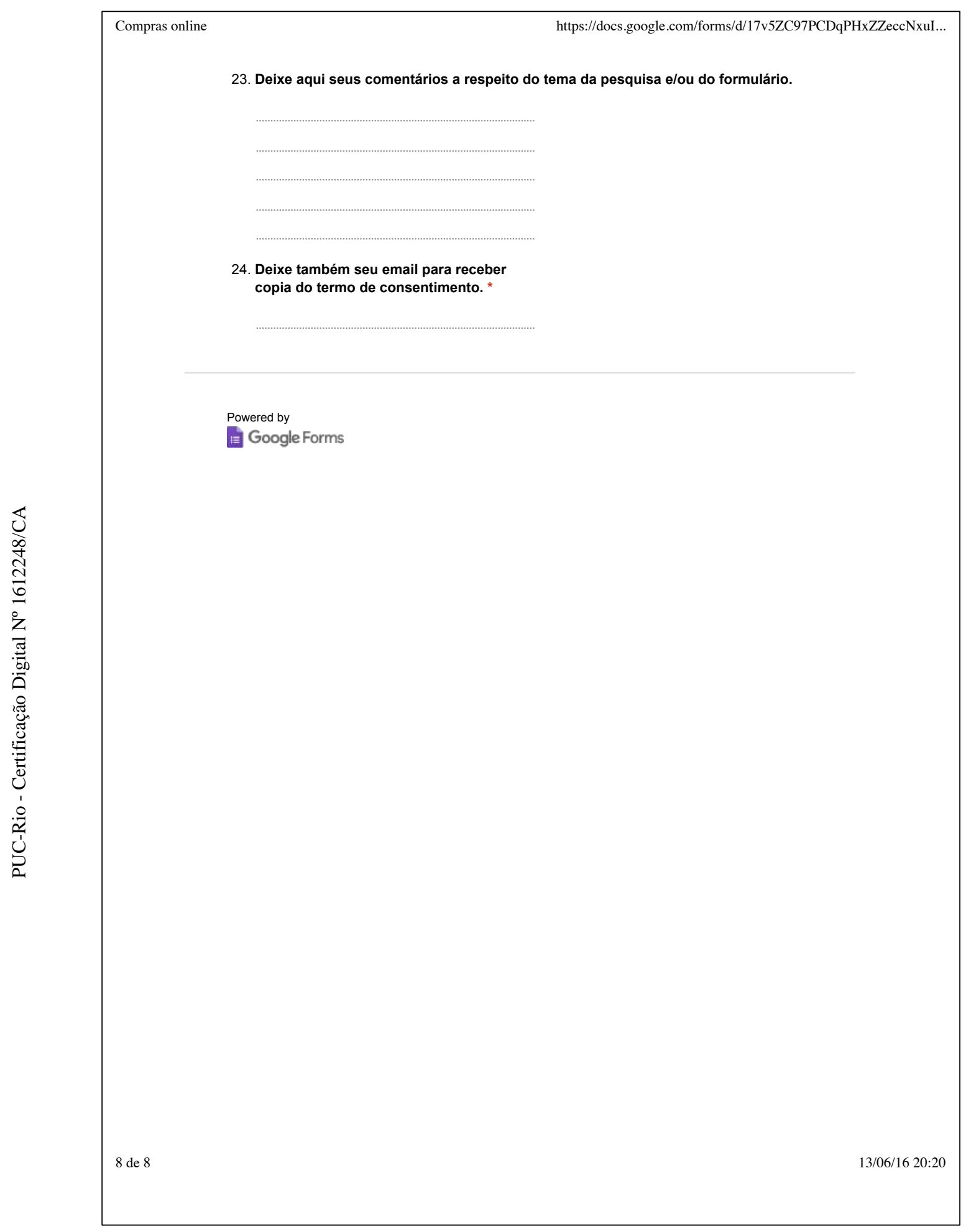


Apêndice 2

Materiais da entrevista com especialistas 
Termo de consentimento livre e esclarecido: entrevista com especialistas de moda

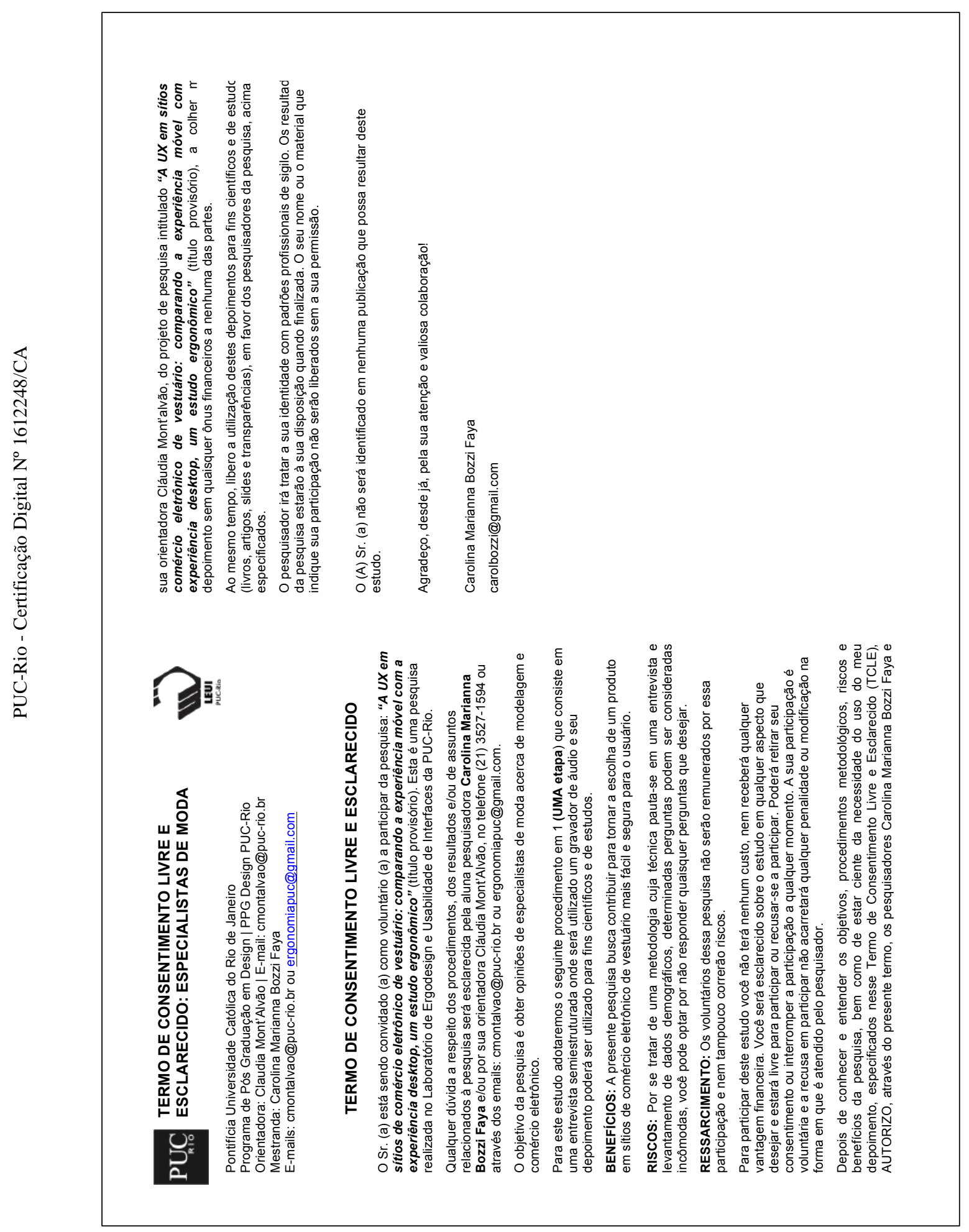




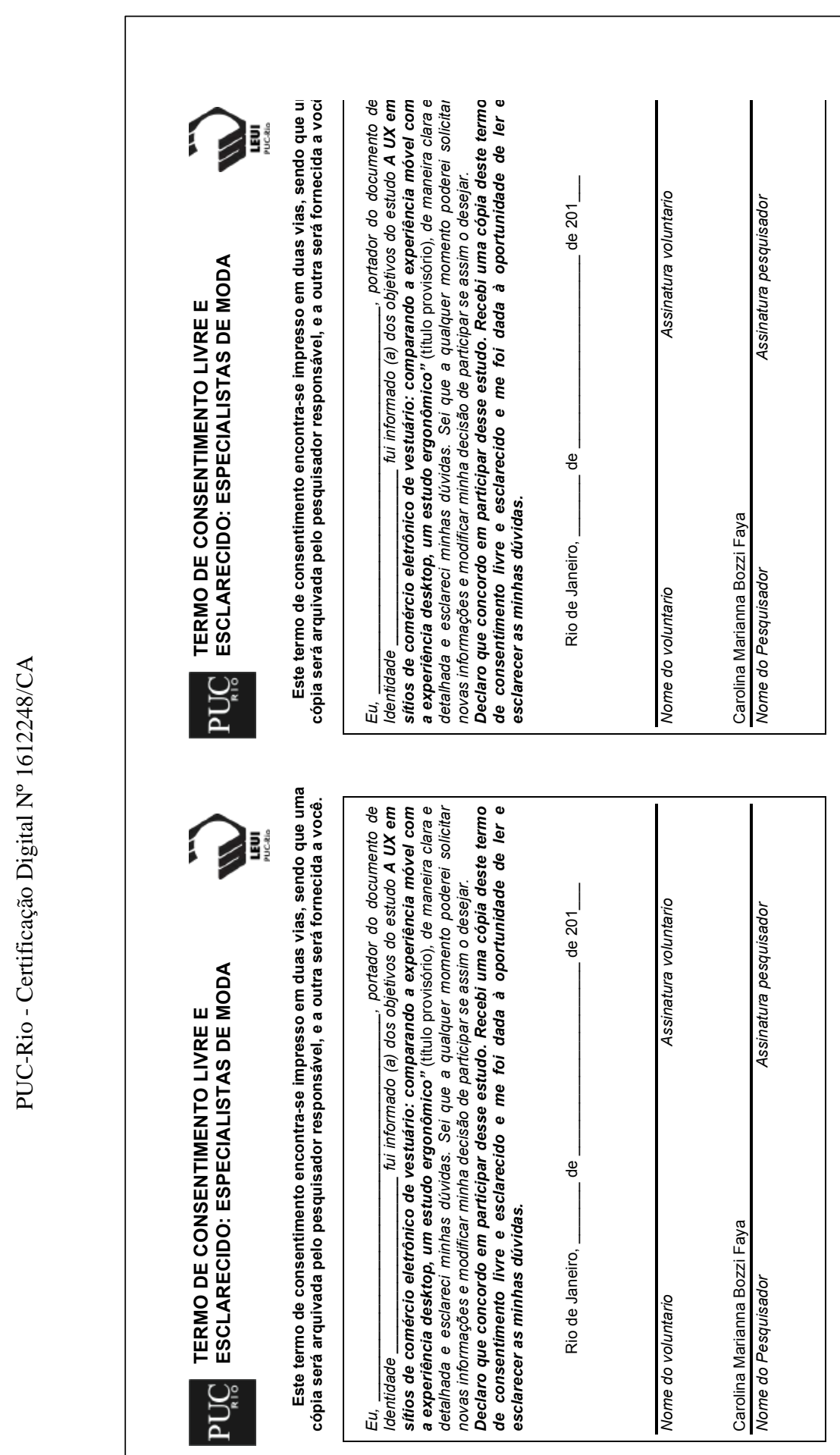




\section{Pauta da entrevista com especialistas de moda}

PUC PAUTA PARA ENTREVISTA

COM ESPECIALISTAS DE MODA

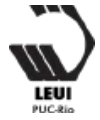

1. Quais são as suas impressões sobre os padrões do mercado de vestuário brasileiro?

2. Devido a grande diversidade nos tipos de corpos das mulheres brasileiras você acha que é possível criar um padrão de medidas que atenda a todas?

3. O que você acredita ser necessário para que um padrão de modelagem seja de fato implementado pelas marcas?

4. Na sua opinião como diminuir a barreira do mundo real para o virtual e dar mais confiança ao consumidor ao comprar uma roupa por meio da internet?

5. Você conhece o estudo realizado pelo Senai Cetiqt a respeito das medidas dos brasileiros e sua aplicação na modelagem? Qual é a sua opinião a respeito?

6. Como você vê a importância na prática desse estudo? Quais benefícios ele pode trazer?

7. O que mais você teria a comentar sobre o assunto. 


\section{Extração dos pontos relevantes da entrevista com especialistas de moda $^{15}$}

1) Quais são as suas impressões sobre os padrões do mercado de vestuário brasileiro?

\section{O que é padronização - como conceituar o termo}

E1 "... ga gente tem que tomar cuidado sobre o que a gente quer falar sobre a padronização".

“A questão da padronização eu fico temeroso, porque quando você dita que isso aqui é um padrão, você está dando que o restante todo pode estar errado, e aí a gente tem que tomar como ponto de partida, que é se isso, aquilo é ou se aquilo será de utilização e a gente vai ter resultado financeiro".

\section{Referências base para a construção do vestuário:}

E1 "Qual a sua referência para você fazer a sua construção para o seu produção de vestuário. É o que eu venho percebendo tanto como pesquisador e como usuário, é que...nós no Brasil ainda não temos...”

“...de que a gente não tem tamanhos que são correspondentes entre marcas, sejam elas de prêt-à-porter ou de streetwear ou de magazine, então você não vê uma coincidência de...da utilização do mesmo parâmetro de medidas para a construção de um vestuário".

E3 "Então o que que é a....a norma, ela está orientando, que seja informada algumas medidas básicas, daquela roupa, por exemplo, de busto, cintura, quadril. E que estatura aquela roupa veste, altura dessa pessoa, e que tamanho seria aquilo. Se esta entre um P, um M, um G, ou 36, 38, 40, de acordo com a tabela de medidas utilizada por essas empresas".

\section{Pesquisas na área:}

E1 “...você tem várias linhas de pesquisa, mas você ainda não tem uma concentração suficiente, uma massa crítica, de que você tenha uma propriedade dessas pesquisas sendo utilizadas, é....para além do campo da pesquisa".

"Então ainda não percebe, tanto na indústria quanto no comércio, é...uma....leitura e uso de várias das pesquisas que são hoje utilizada, é claro....uma pena.....que a gente vê algumas grandes empresas que já fazem pesquisas, individualizadas, que são só de uso próprio não de uso, é....pulverizado e coletivo para toda a sociedade".

"Então hoje a gente tem várias linhas de pesquisa no Brasil de antropometria, de estudos ligados à ergonomia homem-objeto, que cada uma tem as vezes uma linha mas elas se tangenciam e as elas são é...é....de uso para mais de uma, são pessoas que acabam partindo, ou das mesmas fontes bibliográficas ou das mesmas características para a gente lançar um projeto de pesquisa. É eu acho, acredito que é fundamental para você melhorar o grau de acerto do cliente final. Então a gente tem que estar trabalhando análise quantitativa, mesmo, profunda, análise matemática, pra gente melhorar o nosso grau de assertividade, e assim a gente é...melhora, o grau de estoque, o grau de produção, tô trabalhando melhor, tô atendendo o meu público melhor".

Utilização da mesma referencia de medidas para construção da modelagem:

E1 "é...eu estou tentando que todos os meus fornecedores pelo menos cheguem a um denominador comum, para eu ter para o meu usuário a mesma é...tabela, ou o mesmo ponto de partida para eu poder pelo menos saber qual é o rumo que eu estou seguindo".

E5 “...que a grande raiz do problema da falta de, não posso dizer padrão, uma falta de uma referência única de tabelas de medidas no Brasil é que..."

"As empresas, elas costumam utilizar a referência dos profissionais que trabalham com ela. É.....E esses profissionais aprendem modelagem em diversos cursos, materiais diferentes que já não têm uma linguagem similar. Se você for ao mercado hoje buscar bibliografia de modelagem traduzida para o português você vai encontrar uma infinidade de livros em que já apresentação no material não é padronizada, tem diferenciais na apresentação dos nomes das medidas, na forma como se mede, né. E isso é uma pequena parcela de tudo que esse pessoal vai encontrar no mercado para aprender a trabalhar com modelagem".

${ }^{15}$ As transcrições completas das entrevistas podem ser encontradas neste link: https://drive.google.com/open?id=1_Lx6ZTHdgi3I9Ze_pcjHsHTT_HAqgRdx 
"Os profissionais de modelagem também aprenderam é....com mãe com pai que eram costureiros né, é....Tem experiência vasta mas mais prática do que teórica e muitos dos referenciais mais antigos se baseiam em tabelas de medidas europeias. Se você pegar hoje o que o pessoal chama no mercado de 38, 40, 42, e tentar buscar é... uma referência de medida de corpo que tem a ver com a medida que tá indicada no manequim você não vai encontrar. O 38 não tem nenhuma referência de medida relacionada ao corpo feminino, por exemplo, né".

"Um outro problema que interfere muito no que o pessoal adora chamar de padronização dos tamanhos, é que, por exemplo, loja, ela não necessariamente confecciona né? E aí uma marca define qual é o público dela, e ela vai buscar empresas que desenvolvam peças para montar o mix do produto dela né? Ela pensa na, na coleção, o que que ela quer que tenha na coleção, e ela vai procurar confecções diferentes para trabalhar o produto dela. É muitas vezes ela vai buscar empresas que trabalham só com camisa, então eles trabalham só com parte de malha. Empresas que trabalham só com jeans, outras que trabalham com outros tipos de calças que não são jeans. E com isso ela está terceirizando a produção dela. E se ela não sugerir, solicitar que essas empresas trabalhem com uma tabela de medidas que ela defina cada empresa vai trabalhar com a sua tabela. Por isso que uma pessoa às vezes entra numa loja, e ela vai encontrar é...o 38 por exemplo, vai vestir com uma camisa, já Na malha não vai ficar bem, uma calça é... uma calça acetinada, no manequim certo ela vai vestir mas se ela quiser um jeans o 40 , já não vai dar nela. E às vezes mesmo no jeans, ela num modelo de jeans ela vai buscar um 40, e, e vai separar algumas calças manequim 40 achando que todas elas vão dar no corpo dela e não vai acontecer. Isso é um problema da empresa não direcionar que seus fornecedores trabalhem com um tipo de tabela de medidas única que faça com que todos os tamanhos das roupas que ele vai vender na loja sigam um mesmo corpo, né. Então a gente tanto vai ter problemas de cada empresa trabalhar com uma tabela de medidas diferente, como a gente vai ter em empresas que trabalham com fornecedores que trabalham com tabelas de medidas diferentes. Mesmo que eu esteja numa mesma loja eu não vou ter essa padronização".

"E é basicamente, a, o meu, o meu parecer em relação a essa dificuldade, né? Das medidas, a gente aqui no Brasil, não tinha referencial, então o pessoal buscou referencial em vários lugares diferentes e acabou despadronizando mesmo isso".

\section{Indústria}

E1 "Importante quando a gente fala que, é...toda pesquisa quando a gente leva para indústria e para o comércio, ela tem que dar resultado financeiro para aquele que empreende.....que aí a gente vai ver exatamente se aquilo está gerando negócio, se aquilo ali a gente tem um grau de assertividade naquilo que foi pesquisado".

E3 "É, enfim, o que que acontece com essa falta de padronização? É....muitas vezes, os consumidores, eles vão fazer as suas compras em uma determinada marca, e lá ele observa que ele veste um tamanho P. Ele vai comprar um outro produto numa outra marca diferente, e lá o tamanho dele já é o G. Ou seja, na verdade ele fica perdido, sem saber que tamanho é esse que ele veste. O que que acontece, como nós não temos uma norma que padronize essa tabela de medidas, cada empresa, ela vai focar no seu público alvo. Né, isso faz com que aquelas pessoas que não se enquadram naquele público, ela não seja contemplada por aquele produto, aquele produto não vai vesti-la satisfatoriamente. Né, isso acaba gerando um processo de inclusão e exclusão ao mesmo tempo né. E gera uma demanda muito grande de problemas para a indústria também. A gente começa a ter uma sobra muito grande de produtos que não atende determinado público, né, ou cliente quando ele adquire um produto, no caso da internet, esse produto tem que voltar porque aquelas medidas não serviram. Enfim né, isso vai acumulando uma série de questões que vão trazendo prejuízo ao próprio processo industrial".

E4 "Então assim, pra indústria também é complicado né? Pra quem tá fazendo essas roupas, porque ela precisa, é, um, os moldes, eles são adaptados constantemente. Então uma fábrica que produz a roupa da Maria Bonita e produz a roupa da Farm, os moldes são completamente diferentes, os tamanhos! Enfim, isso é, é uma prática quase injusta".

E6 "Que também tem uma, aquela teoria né? "Ah média, mas média não atende todo mundo!" Não. A média vai atender a maioria que puder, pra indústria isso é perfeito, que uma das guerras de todo mundo. "Ah mas por que que essas medidas não têm nada a ver comigo?” Dentro da indústria, a indústria precisa, não tem como sair medindo cada um. Então, ele precisa ter uma média, é claro, depende qual o recorte que ele vai fazer, e que ele vai atender. Não adianta ele falar que vai tipo, que ele quer atender, tipo, pessoas corpulentas e pessoas magras. Sendo que ele quer tirar lucro no maior número possível de coisas que ele quer vender".

\section{Diversidade brasileira}

E1 "Aí a gente vai falar dentro do território brasileiro, é extremamente difícil porque você trabalha com várias descendências, ascendências, você tem uma imigração interna muito grande, você tem uma emigração que é muito grande, então você tem muitas influências que são denominadores que você tem que levar em consideração para quando você vai traçar um perfil que você pretende atender". 
E3 "Que que consiste essa padronização? Quando a gente pensa em caso de Brasil, né. Com muitas regiões de colonização diferente, né, com um clima diferente, uma geografia diferente a gente observa que os biótipos também são diferente. Então tentar sonhar com uma padronização que atenda todo esse público, eu acho que é um pouco de utopia, né. Mas essa padronização ela tem que vim com algumas medidas básicas que tentam atender um mínimo possível desse público".

E5 "Mas dentro das 10 mil pessoas já medidas a gente já tem uma...um, um retrato de boa parte da população, uma boa quantidade de classificação de corpos. A gente tá com 5 tipos físicos femininos e 5 tipos físicos masculinos. É...divididos pelas 5 regiões do país, ou seja, a gente pode trabalhar de forma regionalizada, né? E....dentre esses, essas, esses tipos né? A gente tem mais ou menos uma classe que vai até 15 tamanhos né? Dentro de um, de um, de um tipo desses e que ainda tem a divisão por curto, médio e longo em relação a estatura. A gente tem uma quantidade de tabelas razoavelmente grande né?"

E6 “...O Brasil tem estereótipos muito complexos, tipo é uma diversidade muito grande então assim, eu acho muito difícil se dizer um padrão onde a gente tem uma mistura tão absurda de etnias, que a gente consegue ver, tipo, numa mesma pessoa que tem, tipo, o busto de um europeu mas tem o quadril de uma africana. E você tenta colocar aquilo ali no padrão só que você não consegue, tipo assim, você meio que vai ter que definir tipo qual padrão que eu vou colocar pra ela".

\section{Necessidade de padronização}

E2 “...previa uma futura necessidade do mercado, no caso, de padronizar o seus produtos".

"Primeiro, é....o Brasil ia começar ter que fazer sua produção externa, ou até mesmo exportar, entender como, é...uma tabela de medidas, uma ficha técnica funcionaria. E ao mesmo tempo é.....vendas em catálogos, é....televendas, enfim".

"Hoje a gente se depara com a parte do e-commerce, que sem a padronização não tem como comercializar e fidelizar, os clientes, na compra dos produtos pela internet".

"Seriam compras a distância também, tá? Ainda temos no mercado, vendas por catálogo e esse tipo de referência do padrão de medidas tem que ser muito didático e ser informado isso pro cliente".

"Pro Brasil, isso ainda é um assunto ainda novo, correto? E eu acredito que tá tendo uma busca, uma procura, como....fazer essa comunicação entre as empresas, as marcas e os seus usuários".

E3 “A gente não tem ainda uma padronização né, mais apropriada pra esses tamanhos, para que a indústria possa se pautar sobre isso e que possa oferecer uma segurança maior para esse consumidor. Quando ele for adquirir um produto ele saber qual o tamanho de fato que ele está comprando. E essa situação, ela se agrava ainda mais quando a gente começa a pensar em vendas pela internet, porque aí não tem aquela oportunidade do consumidor tá experimentando a roupa né, e já faz essa compra direta. E os tamanhos, eles variam muito de uma marca para a outra".

E4 "E cada loja, também, tem o seus seguidores, tem os seus consumidores.

...aonde já se viu no mundo, cada loja tem um tipo de tamanho? Né? Então, assim, tinha que ter um padrão. Tem que ser P pra todo mundo, é P! P é busto 38, quadril 98, sabe? É isso! Então assim, é preocupante até! Porque é um engano, é quase um abuso ao consumidor né? Porque ele tá sempre assim: você vai numa loja, digamos, agora mais não porque acabou: Maria Bonita. O 38 da Maria Bonita é completamente, era completamente diferente da 38 da Farm.

"Se compra uma roupa achando, "então é 38", é aquela coisa que você falou: você compra na internet, né? Você vai ,então você vai comprar o 38 , achando que você tá comprando 38,40 , 42, e você chega em casa e não cabe em você".

“É quase uma ilusão, é quase uma ilusão. Um abuso do consumi....diante do consumidor".

\section{Transparência para o consumidor}

E4 "É quase uma ilusão, é quase uma ilusão. Um abuso do consumi....diante do consumidor. (falando da diferença de tamanho de uma marca para a outra)".

Ou seja, estão comprando um produto, que na verdade não condiz com o que, o que está ali. Tudo bem se eles dissessem: "Então tá, o P da Farm, as medidas (são) essa, essa, essa e essa". Se fosse uma coisa né, se essas medidas fossem claras. Então cada um saberia, o que que elas estão comprando. E tem toda uma política de troca no Brasil, que não funciona, cara. Né? Você compra uma roupa, que se prove, se prove ao contrário, que aquela roupa não deu na internet, o, o desgaste, emocional é muito grande.

E5 "O que é mais interessante que a gente pensa, né? Que seria mais interessante pra se trabalhar, é que as empresas que querem atender tanto em loja como em mercado eletrônico, que elas definam pro consumidor 
delas, qual a medida de corpo que elas estão trabalhando o produto. Além é claro, da medida do produto pronto. Existem essas duas referência que são bem é....diferentes. Corpo é uma coisa, roupa, produto pronto é outra".

"Então eu tenho sempre que dar como referência pro cliente a medida do corpo que serviu como base referencial que serviu com base para a da modelagem, né? E eu posso ainda dá umas duas, três medidas, referentes a peça pronta, pra que o cliente possa ter uma ideia, comparar até com roupas que ele tenha na casa dele né? Ele pode comparar um comprimento total, por exemplo, se for uma parte superior do corpo ele pode comparar uma largura de tórax, né? Se for uma parte inferior do corpo, de repente, pode comparar uma largura de quadril, que são as medidas referenciais mais largas né, das peças, ele pode comparar com alguma roupa que ele tenha em casa para ter uma ideia do padrão. E ter as principais medidas do corpo definidas ali pela empresa, né? Medida de busto, cintura, quadril, a estatura, né? De repente uma entreperna, que são medidas que também vão ajudar a pessoa a se encontrar, "Ah essa empresa trabalha com um corpo mais ou menos parecido com o meu, então vale a pena adquirir uma roupa nessa, nessa empresa".

\section{Mudança do corpo do brasileiro ao longo do tempo}

E5 "As pessoas elas, elas cresceram né? Elas estão mais altas, elas tem uma tendência a aumentar o peso, a estar com sobrepeso. E as correspondências das tabelas não seguiram essa evolução, esse crescimento das pessoas".

"É...os brasileiros, principalmente da região Sudeste, tem um crescimento, um alto índice de sobrepeso e de obesidade aí em evolução. E a gente entende que tem ter um referencial um pouco mais fortificado desse tipo no estudo né?"

\section{Fator psicológico das medidas (vanity sizing)}

E5 "Quando você trabalha com moda você trabalha com vaidade, vaidade, marketing. Então muitas vezes a empresa ela quer atender um, uma pessoa que tem o corpo um pouquinho maior, mas ela vai e coloca a sua etiqueta dela um pouquinho menor para a pessoa se sentir, é...falsamente elogiada no seu tamanho. "Ah! Eu visto $\mathrm{M}$ !" A pessoa, ela tem um tipo de corpo que de repente é pra o G, mas a empresa muda a, o manequim pra atender a, essa parte de marketing. Vou chamar isso de marketing porque é o ideal tá? Proporcionar um produto dos sonhos pra aquela pessoa vestir. Isso é muito comum no feminino, né?"

"Se for multiplicar isso tudo, (a quantidade de formatos de corpos e tabelas) isso quer dizer que a gente não pode ter uma padronização de forma assim, ah chegar e dizer: Ah, dá pra padronizar, uma tabela de medidas pro Brasil. Até dá pra tentar, não quer dizer que vai vestir bem as pessoas se colocar todo mundo dentro de um pacotão, né”.

\section{Contribuições do estudo antropométrico para soluções eletrônicas com o Sizebay}

E5 "Então nossa intenção com o estudo antropométrico a partir da liberação inclusive das tabelas de medidas, é as empresas verifiquem que tipo de tabelas elas estão trabalhando hoje, se elas podem encontrar tabela delas dentro desse mundo de tabelas que a gente identificou pelo Brasil. E aí com isso ela pode até chancelar o trabalho dela, e deixar isso de forma mais visível pro cliente. Ela pode criar um tag, alguma informação se ela for loja, né? Alguma informação diretamente na roupa e se ela for mercado eletrônico, ela pode colocar essas referências no site, pra que o cliente possa é...pesquisar, né? Inclusive tem alguns sites lá fora, que você escreve a sua marca neles né? Aí o consumidor ele pode colocar as principais medidas do corpo dele lá, né? Define é...o biótipo dele, e o site apresenta as marcas que tenham mais a ver com o corpo dele, pra ele pesquisar e adquirir roupa, né?"

"As empresas que têm interesse de entrar na, na plataforma deles né? Elas adicionam os produtos ali né? Aí um consumidor ele pode entrar ali e identificar a partir de poucas informações, ele deduz o manequim dele. $\mathrm{Ah}$, nessa marca o teu manequim vai ser esse, vestido com mais conforto, ou menos conforto. Ele já dá uma indicação de conforto pro, pro cliente né? É um case bem interessante, se não conhece acho legal ...pesquisar. (Sobre a Sizebay)".

"Isso! Que é um, um, caso interessante desses. Então ele proporciona uma plataforma, onde a empresa ela vai cadastrar os produtos dela, né? Com medidas dos produtos prontos e vai indicar também medidas do corpo, com sugestões que a gente deu pra eles né? Eles tem uma inteligência artificial, onde a pessoa digita algumas medidas e ele vai buscar aproximar essa medida com os grupos que eles têm gravadas, no processador deles. E aí eles já direcionam a, a pessoa pra aquele manequim com graus de folga pra cada marca que eles tenham associados lá.

Melhora do grau de assertividade

E6 "O Senai, ele pegou, várias partes do Brasil, mesmo, e tá, tipo, pelo menos eu acredito que eles fizeram com muitas pessoas. Assim, eu acho que consegue chegar, talvez, numa medida um pouco melhor pra atender uma massa."

\section{Diversidade nos tamanhos}


E6 "Apesar de que, hoje quase, acho que nenhuma indústria já segue esses padrões. Cada um cria o seu próprio padrãozinho, já observando o próprio público, até porque eu acho que fica bem interessante isso, né? Você tá tipo, as pessoas tão começando a ter uma percepção de olhar pro próprio público.

\section{Produção em massa}

E6 "Cada um cria o seu próprio padrãozinho, já observando o próprio público, até porque eu acho que fica bem interessante isso, né? Você tá tipo, as pessoas tão começando a ter uma percepção de olhar pro próprio público. Mas a China jamais vai fazer isso. Ela só quer vender a rodo, e tipo assim, 100 mil camisas, e tipo, como você vai fazer 100 mil camisas e tentar fazer uma variação, tipo de 20 modelos. Eles n vão fazer isso".

\section{Prejuízo na modelagem em prol da massificação e lucro}

E6 "Na verdade é uma questão de prejuízo. E, grandes n querem ter prejuízo algum né? Ah, é aquela coisinha: vai passar, consegue passar. No Brasil, como a gente sempre tem o jeitinho brasileiro, "Ah não tem problema não, ninguém vai ver".

a) Devido a grande diversidade nos tipos de corpos das mulheres brasileiras você acha que é possível criar um padrão de medidas que atenda a todas?

\section{Aumento do grau de assertividade}

E1 "Eu acredito que a gente pode sim melhorar, o grau de assertividade, primeiro se a gente considerar, que é uma coisa que a gente já vinha fazendo na pesquisa que era você trabalhar, não por numeração, não por $\mathrm{P} M$ $\mathrm{G}, 32,38,40,42$, mas sim por circunferência, é...é....e algumas alturas, porque quando você trabalha a circunferência, você tem a probabilidade de melhorar a sua assertividade, porque quando eu te digo que um 42, por exemplo, pode ser um $84 \mathrm{~cm}$, aí eu tô dizendo que somente o 42 é 84 . E aí assim pode dizer que 42 de uma marca A que é $84 \mathrm{~cm}$, na outra é 90 e na marca C pode ser $92 "$.

"Se a gente pode atender a todas, acredito que a gente pode, a todas eu não sei, acho que é demais você dizer: "Ah eu acerto em 100\%". Mas, ah, eu acredito que, quando você começa a tomar esses cuidados desses parâmetros de circunferência, fazer comparativos, análise da marca, ou do segmento que você tá trabalhando e você falar que aquilo ali, ela vai te ajudar a melhorar o grau de acerto da sua produção. Então hoje, aí eu falo como, no de novo no empreendimento, né, que aí eu vou pelo grau maior de assertividade para atender os meus cliente finais".

"E aí, é....100\%? Acho difícil, mas você tem a probabilidade de aumentar o acerto da sua entrega. E aí levando todos esses parâmetros em consideração..."

"Sim, sempre defendi essa tese, que seria padronizar para o mercado, atendendo o maior número de pessoas. Com certeza, a gente nunca vai conseguir atender $100 \%$, mas o mais importante, seria, o maior número de pessoas".

"Continuo, indiretamente e diretamente trabalhando para a feminina e masculina, mas dentro do infantil a gente percebe melhor a assertividade quando a gente partiu para a centimetragem. Porque aí você começa a ter uma melhora da entrega final do seu...do cliente final que é o infantil.

E3 "Então eu acho que pensar numa, possibilidade de padronização que vá atender a todos esses corpos femininos do nosso país, eu acho que é impossível. Mas o que a gente tem que levar em conta, é tentar uma, uma possibilidade de tentar padronizar o mínimo possível”.

\section{Fatores psicológicos da numeração (vanity sizing)}

E1 "O que você também tem que levar em consideração, são os fatores psicológicos, então é...quando eu digo que sou uma mulher, ou sou um homem é....e estou dentro do tamanho 42, mas segundo que critério, o que tabela, ou que parâmetro anterior p eu dizer que aquilo ali é 42 ”.

"Quando você sugere né, que eu tô trabalhando centimetragem, que aí vamos supor, essa calça, ou essa blusa, é...vai estar uma circunferência, de busto ou de tórax, que ela pode estar entre 102 e 104. Então eu já estou dizendo que ela pode estar dentro daquilo ali, mas eu não estou dizendo se ela é P, ou se é M ou se é G. Então acredito que quando a gente tirar esse, talvez, que não é fácil, a gente já viu que alguns países europeus, alguns países da América do Norte, da Ásia já adotam, claro com um paralelismo, né de isso é P ou 1, que abrange a circunferência de x a x, mais 4, por exemplo. Aí você melhora o acerto".

E2 OBS: em resposta a uma pergunta extra (entre marcas como que é possível manter uma consistência de modelagem, pra que eu saiba que o meu tamanho é igual em uma e na outra e assim ter confiança no que eu compro online?): "Na realidade, a gente ainda tem algo a conquistar, porque têm marcas que trabalham com psicológico, que o 40, o tamanho 40, vamos supor, para ele é....seria um 42, tamanho base 40 dele, vestiria um 42, de uma outra marca. Tem marcas que são mais jovens então ela não se incomoda, um 38 é um 38 , um 40 é um 40 . Tem outras marcas que 
não, elas consideram um tamanho 40, outras elas consideram um tamanho intermediário, o...tamanho M dela é um 39, ela não é nem um 38 e nem um 40. É um 39, tá?”

E4 "Então você chega numa fábrica, cara, é uma loucura! E um desperdício muito grande né? Então assim, por que o q acontece com os tamanhos, a Farm, fala: "Não, o meu P, a mulher que veste a nossa roupa ela é 28 ", mas é um 28 , as vezes é PP"

"Não é nem P, que não passa nem na sua coxa. Aí você chega né, digamos, sei lá na, sei lá, Sacada, sei lá, numa dessas lojas, e você chega lá, mas pera lá! O P já não é o $\mathrm{P}$, o M, então você não sabe muito como se encaixar né? Eu acho que o problema, de comprar roupa no Brasil, online, é justamente por isso, porque você não sabe o porque você está comprando".

\section{Comunicação com o usuário}

E1 "Primeiro, uma comunicação direta com o meu usuário, e um feedback constate para com a marca, se eu estou fazendo aquele caminho certo".

E2 "Você vai atender o maior número de pessoas, e as vezes você num consegue atender, por exemplo, a pessoa em cima é um número, em baixo é outro. Isso também tem que ser informado ao cliente..."

“...na minha opinião, é totalmente possível, padronizar”.

OBS: em resposta a uma pergunta extra (entre marcas como que é possível manter uma consistência de modelagem, pra que eu saiba que o meu tamanho é igual em uma e na outra e assim ter confiança no que eu compro online?): "É....então, na minha crença, hoje, para a questão do e-commerce, essa comunicação com cliente, ele tem que ser muito didático na hora de informar as medidas, é...referente à numeração que ele vai trabalhar, ele tem que ser muito didático e deixar isso muito claro pro público consumidor. E ter, talvez, um canal que ele, o público consumidor, tire as dúvidas, caso ele compre algum produto, caso ele não consiga entender como se medir, e identificar essa numeração, seria isso".

\section{Diversidade dos corpos}

E3 “..nós estamos num país de dimensões continentais, né. Com várias regiões que foram colonizadas de maneiras distintas, onde nós temos um clima diferenciado, com uma geografia diferenciada, né. E até com uma economia e política também, que sofre variações de uma região para a outra. Isso influencia muito no biotipo de cada corpo né, dessas regiões separadas. Então eu acho que pensar numa, possibilidade de padronização que vá atender a todos esses corpos femininos do nosso país, eu acho que é impossível. Mas o que a gente tem que levar em conta, é tentar uma, uma possibilidade de tentar padronizar o mínimo possível".

"Pra que as empresas também, não fique totalmente à vontade, pra cada uma criar a sua tabela de medidas. Então eu acho que a função dos estudos de antropometria e de modelagem que estão sendo realizados no Brasil nesse momento, é de se criar uma orientação pra que se consiga estabelecer um mínimo de medidas básicas que sejam utilizadas na produção desse vestuário né, no desenvolvimento das bases de modelagem".

"A gente vê muito que em determinados locais as mulheres têm um quadril bem mais avantajado do que a cintura. Em outros lugares as relações entre busto e quadril não são tão harmônicas como em outros, né. E assim sucessivamente. É...isso sem falar né, nas variações de...cirurgias plásticas, desse tipo de intervenções estéticas, que são realizadas né, e o Brasil é um dos campeões nesse tipo de procedimento, que isso acaba criando uma alteração nesse corpo feminino".

E4 "Acho sim. Até porque nós somos assim, nossos corpos são muito parecidos. Né? A gente num...o que muda é o P, M e o G. Mas a gente tem uma coisa, né? As mulheres brasileira são uns petites, somos pequenininhas, claro que você vai pro Sul e as mulheres são mais europeias, são alemãs, holandesas, mas assim em termos de padrão, de quadril e de busto, nós somos muito parecidas".

"O que muda justamente, as mulheres têm mais peito né? Mais cintura e são...quer dizer, têm mais bunda, mais quadril, mas as cinturas são muito pequenas. Eu acho, claro que tem um padrão, de, é bem possível de criar se um padrão que caiba em todas as mulheres, com certeza".

\section{Necessidade de padronização}

E3 "Então, que que eu, eu, eu acredito? Eu acredito, que esse estudo ele vai possibilitar que a gente consiga desenvolver uma padronização mínima. Tentar criar se um referencial para que o desenvolvimento da modelagem ele seja em cima disso. Pra que essas tabelas de medidas elas não sejam tão discrepantes, né. E buscar uma proporção que consiga atender, né, o máximo possível desses corpos com biótipos diferentes que nós temos aqui no Brasil".

E4 "Seria muito mais fácil pra indústria, né? Pro, pro, pro comércio. (Sobre padronização)". 
E5 "É aquilo que eu falei, eu acho que a gente vai criar mais de um padrão. Por biotipo físico, por região e por estatura. Padronizar um único tipo, vai ser um pouco complicado. A não ser que você faça peças de roupas já é....o design dela pensado pra ser ajustável, né? Uma, uma calça, por exemplo, que tenha cintura ajustável, que tenha comprimento ajustável. Um vestido que também possa ter isso, esse tipo de ajuste na silhueta dele né? Eu acho que dá pra pensar em peças que atendam de forma mais universal. Mas definir na raiz, na tabela de medidas, é um pouco complicado".

Impossibilidade de padronização devido a grande diversidade de corpos

E6 "Impossível! Porque é, tipo assim, talvez, vou separar em dois tipos de tecido. Malha talvez você consiga tipo, ter uma variação maior, por causa da elasticidade do tecido. Mas uma calça jeans, impossível. Como que eu vou colocar uma mulher que é, tipo, tem o biotipo trapézio com a outra que tem funil?”

2) O que você acredita ser necessário para que um padrão de modelagem seja

de fato implementado pelas marcas?

O que é padronização - como conceituar o termo

E1 "É muito rígida, porque você está dizendo assim, aquilo está padronizado. Mas, eu sou uma pessoa fora do padrão, você tá no padrão? (Sobre a palavra padrão)"

"Então, mas aí qual é o parâmetro para o padrão? Entendeu, acho que são coisa importantes para discutir também".

\section{Mudança nos corpos dos brasileiros}

E1 "as marcas é....observarem que existe pesquisa, primeiro que existe pesquisa. Que o corpo, tanto da mulher brasileira, quanto do homem brasileiro, quando da criança brasileira, vem passando por um processo de mudança, se a gente falar de comportamento e consumo. Hábitos alimentares, hábitos na sua residência, de esportividade e de grau de acesso a informação. Se a gente falar é...que o tipo de corpo de uma pessoa que mora perto da praia é diferente do tipo de corpo de uma pessoa que mora no interior. Que é diferente de uma pessoa que mora é...no Norte, Nordeste, no Sul no Centro-oeste".

\section{Conhecer o público}

E1 "Então se a gente fala de uma marca, ela primeiro, ela tem que entender para que, onde e para quem eu estou atendendo. Que eu posso dizer assim, vou pegar como exemplo um magazine que tem um atendimento de âmbito nacional é.....o grau de assertividade, volto na palavra assertividade, dele talvez seja ter o reconhecimento de que talvez eu possa fazer, atender o Norte como exemplo, com tamanhos menores, por causa da sua ascendência e descendência e miscigenação, que é diferente dos homens e mulheres do sul que tem outro tipo de ascendência e descendência e misturas".

"Então, assim são a gente pensa na marca ela tem que começar a olhar mais o usuário, no sentido que esse usuário está mudando o seu corpo. E aí esse corpo ele tem que estar relacionado a um estudo antropométrico, esse estudo antropométrico tem um grau de assertividade matemático, para você melhor confeccionar um produto que você tem que atender o mercado".

"Automaticamente aí você vai falar de modelagem. Eu melhoro a minha modelagem em relação ao meu usuário através de circunferências e alturas porque aí eu vou poder fazer ou uma modelagem plana, ou uma modelagem tridimensional via $\mathrm{CAD}$, ou uma modelagem via drape ou moulage de forma diferenciada. Aí eu vou atender melhor o meu cliente final".

“...eu já tive a oportunidade de fornecer pra C\&A, também já forneci para o Carrefour, que são marcas internacionais mas usam fabricantes brasileiros também, além de trazerem produtos comprados fora, mas aí você tem que entender para quem eu estou atendendo esse cliente, e aí eu tenho que ou adaptar por região ou adaptar por segmento e gênero.

E2 "Então na hora de escolher, e definir, é super importante que ele conheça o perfil,

\section{Retorno para a marca}

E2 "Um padrão de medidas para uma boa modelagem ser implantado pelas marcas....é.....seria....por exemplo....pra marca o mais importante é o retorno que isso vai dar.

\section{Confiança no produto que está comprando}

E2 "Pro cliente, a fidelidade, né...do cliente pela marca. E, a confiança, no produto que ele está comprando que vai vestir o biotipo dele".

\section{Feedback constante dos consumidores}

E2 "E....ouvir sempre o que que o cliente precisa e adequando essa modelagem, né? Esse padrão de medidas, de acordo com esse público que está comprando a marca? Tá”. 
Referências de confiança para construção da tabela de medidas

E2 "Agora, ele precisa ter uma tabela de medidas confiável. E na realidade um excelente profissional pra desenvolver esse tipo de modelagem. Um profissional com experiência, com conhecimento e focar também na ergonomia para que a roupa seja, atenda às necessidades do público consumidor".

\section{Normatização}

E3 "Talvez a gente ia pensar em uma...normatização que fosse fiscalizada pelas entidades responsáveis por isso, talvez fosse uma das opções né. Eu acho que essa normatização ela deve partir da indústria, né, que é quem de certa forma acaba ditando as regras né? Para que as confecções, as marcas né. Possam trabalhar em cima disso. Mas ao mesmo tempo eu acho que é muito difícil uma fiscalização tão rigorosa em cima disso né?"

\section{Demanda do consumidor por uma padronização}

E3 "Eu acho que na verdade o que vai acontecer é uma resposta do próprio público mesmo. A partir do momento que for havendo essa implementação dessas medidas, né. As marcas que forem aderindo a essa padronização, elas vão começar a diminuir os seus problemas de vestibilidade, e isso meio que de certa forma vai agradando o seu público consumidor, né?"

\section{Moulage como um método mais assertivo para a modelagem}

E4 "Assim, eu acho, que o que, o que o Brasil precisa é moulage. Enquanto Europa, a Ásia, Escandinávia, né? Os, os, tem uma cultura, os grande ateliês, eles trabalham com moulage, há anos. E até o mais street, o ready to wear, todo mundo faz roupa no moulage. Quando você entra em uma faculdade lá na Europa, por exemplo, eu fiz faculdade na Inglaterra, em Londres. Você só aprende moulage. É muito raro, você aprender modelagem plana. Você aprende porque você tem saber, porque indústria ainda te cobra, você saber. Mas não porque é, é, não há essa necessidade, até porque, por exemplo, o, a margem de erro é muito baixa, quando você faz as coisas no moulage."

"Então assim você quase não, você sabe exatamente quanto você vai gastar de metragem pra fazer um vestido, então você não compra excessivo, né? A modelagem plana é tudo muito matemático demais, então você perde muito tempo fazendo aquele molde, enquanto assim o, o, o, o moulage, ele está lá, ali na sua frente. Sabe? Ele cria formas também, o tecido fala onde ele quer fazer, cair. Então você consegue botar a pence no lugar certo, em vez de ficar tudo matemático, ah mede aqui, tira dali”.

"É mais dinâmico, muito mais dinâmico. E a margem de erro é baixíssima. E de waste, sabe, desperdício, na hora de produção. Você compra a quantidade exata, enquanto o seu molde plano, não que isso não te dê essa quantidade né, essa coisa de volume. Quantidade pra fazer determinadas peças".

"Totalmente, porque assim, problema...quando você faz o seu moulage no seu ateliê, ou onde você trabalha, assim, aquela peça piloto, ela sai pronta pra indústria. Pra ser produzida".

\section{Adoção dos resultados do estudo do SENAI ou demais estudos}

E5 "Se eles acreditarem em um estudo né, que tenha sido feito como o nosso né? Fizerem essa análise do que eles têm hoje, se aquilo pode ser localizado ali, no...estudo, acreditar nisso né? Investir na mudança da modelagem deles, no caso de necessidade né? Principalmente as marcas que têm um grande número de retorno de peças. Se elas registram isso de alguma forma, elas têm uma ideia dos problemas que essas peças estão dando, né? A cintura ficou muito larga, ou então a entreperna essa pessoa tem que cortar uma quantidade de tecido muito grande. Se ela tem isso anotado de alguma forma, até a preocupação com o produto dela, vai ser mais fácil ela fazer esse cruzamento de informações, acreditar, e fazer essas mudanças.

\section{Respeito a individualidade de cada marca}

E5 "Mas a nossa ideia é...inclusive não tolher de forma alguma a individualidade da marca, também se a marca é...Assim, há mercado pra todos né? Se a marca identifica que ela quer atender um público alvo específico, a única coisa que ela tem que ser, é clara. Ela não só, ela vai falar, de forma clara, da parte do, do valor da marca, do que ela pretende atender, como ela deve expor essa parte da, do corpo de quem ela pretende atender. Porque se o cliente chega lá e verificar: "Não, infelizmente essa marca não tem nada pro meu corpo". Mas aquela marca, ela foi criada pensada sobre um determinado tipo físico, e ela vai atender bem aquele determinado tipo".

E6 "Eu acho muito legal cada marca criar o seu, a sua tabela, seus padrões que você segue ali assim, claro, ela só vai fazer isso observando o público dela. Então assim, talvez o público dela vai ser sempre aquele corpinho tanajura, a bundinha dela é sempre grandinha. Minha tabela vai ser assim, o busto dela é fininho e a bunda, e o quadril dela é largo. Não interessa, o meu padrão é sempre é esse. Isso eu acho muito interessante de ser feito. E não, elas não deveriam entrar num padrão que tipo, uma ABNT vai, vai tachar para todo muito. "Ai, todo mundo tem que, é obrigado a seguir isso". Então você pode fazer desde que você faça um acompanhamento do seu público". 


\section{Desnecessário um padrão}

E6 "É porque eu não acho, hoje eu venho, como eu tô já me envolvendo com isso, hoje eu não acredito que seja mais necessário esse padrão".

\section{Fator psicológico das medidas (vanity sizing)}

E6 "O que acontece de errado é que existe uma tabela, e as marcas estão se colocando de uma forma, psicologicamente degradante pras mulheres. O que acontece? Você sabe que tipo, nos padrões, em questão de medida, por exemplo, se você tiver um quadril x, e aquele quadril x, é respectivo ao tamanho 42, elas usam da má fé, e tipo, falam assim: "Não, essa calça aqui é 38". Só pra pessoa se sentir bem. Mas que na verdade ela tá vendo que aquilo ali não entra. Isso eu acho errado, tipo, as empresas se colocarem dessa forma. Até porque tipo assim, o tamanho 42 , corresponde algumas tabelas, porque existem tipo, medidas ali que façam com que ele se encaixe no 42. Agora você passar esse 42 pra alguma coisa que, tipo, de verdade, na verdade não é. Porque assim, só se tipo, todo mundo falasse olha: Ah, uma zona aí! 36 é o novo 44. Aí tipo do 44, vai ser o 36 , do 36 vai $34,32,30,28$. Pra pessoas se sentirem melhor, que não vai acontecer. Mas na verdade é, tipo, ela sabe que ela tá vendendo 42 , mas coloca 38 só pra conseguir vender, porque é uma característica de mulher se sentir bem quando tem uma numeração melhor".

"Agora essas empresas, principalmente, que se joga 36, numa coisa que eu falo assim: Jamais isso aqui é 36. É uma ilusão total, total. E eles fazem isso, é, realmente, de má fé. De má fé mesmo. Mas uma vez, é só a indústria querendo tirar vantagem e consegue".

\section{Informação e transparência para o consumidor}

E6 "....cada empresa poderia fazer a sua (tabela), claro sendo sensato, transparente pra não vender algo que não condiz".

"Mas agora assim, seguir o padrão da ABNT de uma tabela, seria bom pras pessoas que não querem entrar nessa...nessa....nessa linha de desenvolvimento, não sei o quê. Talvez seria tipo, uma exigência, existe uma exigência das etiquetas, são obrigações que todo o, todo o produtor tem ter. CNPJ, que não sei o quê, tipo de lavagem, composição. Talvez seria até interessante eles colocarem, tipo, tabela, de qual tipo de tabela eles seguem. Tipo se é tabela da $\mathrm{ABNT}$, a oficial da $\mathrm{ABNT}$, tá lá. Se não for, é tipo tabela interna e eles disponibilizarem essa tabela ali dentro, tipo, de alguma forma pro consumidor pra saber quais são as medidas".

3) Na sua opinião como diminuir a barreira do mundo real para o virtual e dar mais confiança ao consumidor ao comprar uma roupa por meio da internet?

\section{Informação e transparência para o consumidor}

E1 "Sem tocar, sem provar. O que eu venho percebendo e aí eu acho bacana se você trouxer para o seu trabalho é....marcas que hoje em dia estão vendendo online com muito sucesso e já estão utilizando ou uma tabela de medida ou uma forma de indicação de medição. E ai eu posso pegar como exemplo aqui, a Richard's ela tem, é....uma tabela de medidas, você pode mexer, medir. É você pega a assertividade, se você pegar a Dafiti ela também vai te dizer com você mede para você comprar e melhorar a assertividade”.

"Como que você melhora o grau de acerto que é a troca muito mais difícil, então eu acredito que quando você apresenta uma tabela é... de medida, seja, que venha a ser da sua marca, ou que venha ser com base em algum instituto de pesquisa ou que você tirou a medida de uma pessoa e botou ali e parametrizou....se você deu os parâmetros e eu tô fazendo uma gradação de 4 em 4, de 6 em 6, de 2 em 2 aí é a empresa que vai estar determinando aí eu não estou seguindo nenhum tipo de tabela anterior, mas eu estou dizendo ali o que eu faço".

"Se ela (marca) tá seguindo ou não um tabela, aí é uma outra coisa, mas quando ela pelo menos já apresenta uma tabela de medida e uma forma de fazer, eu vejo que essas empresas começam a melhorar o grau de venda e de assertividade, com o consumidor e o usuário final para compra on-line".

E2 "Olha, para fidelizar e tornar confiável, primeiro lugar, todos os seus fornecedores ou se é uma marca só, ela tem que ter o mesmo padrão de medidas para qualquer modelo, que seja. Então aquele modelo, independente do modelo, tem que vestir sempre o mesmo corpo".

"Então, eles fotografam a roupa vestida no nosso manequim. E fornece essas medidas para os clientes, e a grade tem que respeitar esse padrão de medidas".

"Então o cliente quando compra naquela marca ele sabe como que a roupa vai vestir nele.

"E esse padrão tem que ser informado para o cliente. Como ele deve medir o corpo, e isso pode ser até demonstrado num tutorial com o manequim, né? Através do corpo do manequim, como ele deve medir o corpo dele. Seria uma sugestão". 
E3 "No nosso mercado contemporâneo. Eu acho o seguinte: a partir dessa padronização de medidas né? Essa padronização quando eu digo, é uma padronização básica, que vai orientar determinadas medidas básicas, eu acho que as empresas devem oferecer essas medidas pro seu consumidor".

"Nós vamos desenvolver uma grade de medidas, desculpa, uma grade de tamanhos, dentro de uma tabela de medidas específicas, onde nós vamos pilotar esses tamanhos, né? Fazer todas as adaptações necessárias, vê quais os tamanhos de fato aquela tabela de medidas está vestindo, e criar no nosso site uma espécie de um avatarzinho, onde ali nós vamos informar para o nosso cliente cada tamanho, quais são as medidas que ele veste. Por exemplo, ah nós estamos trabalhando com tamanho $\mathrm{M}$. O tamanho $\mathrm{M}$ da minha dólmã, ele vai vestir uma pessoa que tem um busto de...100 centímetros, que tenha um ombro de 15 centímetros, que tem uma altura de ombro né até o quadril de 75 centímetros enfim...e por aí vai né? Obviamente nós não vamos dar todas as medidas, mas algumas medidas referenciais, que são mais básicas e que com certeza aquele produto vá vestir o meu consumidor".

E5 "Eu acho que é fundamental ele um, passo a passo de como a pessoa deve se medir pra ela poder comparar a medida dela com uma medida que deve tá apresentada ali no site em relação ao corpo dela. Pode ter também, um passo a passo de como medir uma roupa, uma referencia de roupa que ela tenha, pra ela ter uma ideia de quanto de folga tem no produto que eles estão vendendo. Eu acho que, é, tornar a pessoa auto suficiente na hora que ela tá adquirindo, é muito bom. Se puder ter uns videozinhos, ilustração, nada muito bobinho, algo fácil didático, mas que apresente como que a pessoa deve ser medir, de repente ela pode até...Tem agora uma fita métrica agora muito interessante, que ela vem com um leitorzinho, agregado a ela. A pessoa ela, ela coloca fita, ela compra essa fita, ela compra essa fita, ela se mede, e essa fita ela já dá certinho e tal pra ela. Aquilo ali ela já vê no site pra identificar qual a roupa que tem mais, mais a ver com ela, ou como seria a relação do corpo dela com essa peça. Então são coisas que podem ajudar, né? tem fita métrica que ela pode imprimir, né, o cliente pode imprimir, de repente ele não tem uma fita em casa, mas ele pode imprimir a fita e se medir. Ações que facilitem a vida da pessoa na hora de adquirir o produto. E colocar, definitivamente, colocar as medidas que ela trabalhou de corpo ali pra pessoa poder se identificar".

"Pode até não ser todas as medidas de peças mas as principais".

E6 "Como não fazer com que as pessoas devolvam, conseguir reduzir essa quantidade. Então tipo assim, dá maior quantidade de informações para a pessoa, pra ela conseguir tipo, chegar ao resultado e saber o que que ela está comprando".

"É....Depois disso você oferece a tabela pra pessoa e...tipo, uma forma, as instruções de como a pessoa deve tirar a medida, tipo, medidas essenciais. E sempre indicando: "Ah tenta ver com uma outra pessoa". Porque, tipo, tirar busto, você fica tipo: "Ah, atrás tá tudo torto". Tirar medida errado também....não vai ajudar em nada".

"E depois fornecer a informação exata de cada produto. Que as, tipo assim, as, as.....as empresas seguem uma tabela, pra você ter pontos básicos. Mas você pode misturar aquilo, por exemplo, eu posso pegar um top, um busto de, de um número, mas colocar a cintura de outro. Então assim, você não pode só jogar uma tabela ali, tipo, se guia aí. Tipo, ali, aquela informação, onde q você vai vender o produto, você tem opção, observações. Busto tal, cintura tal, quadril tal, comprimento tal, tipo, manga tal, pra pessoa conseguir comprar uma coisa e sentir até mais confiável...”

\section{Diversidade nos tamanhos e a impossibilidade de experimentar}

E3 "É...na verdade, o, a grande dificuldade né, nessa barreira entre o mundo real e o virtual né, aqui no caso entendo na, na venda pela internet, é exatamente a impossibilidade do consumidor experimentar essa roupa antes de adquirir né. E isso gera um problema muito grande, porque as vezes ele compra uma roupa, e aquela roupa tá falando que ela é $\mathrm{M}$, esse $\mathrm{M}$ é o tamanho que ele normalmente acredita vestir, de repente essa roupa chega e ela não veste. Aí ele tem que devolver, pra fazer uma troca, enfim, isso cria um desgaste muito grande, uma perda de tempo muito grande né? E acaba meio que...desclassificando esse tipo de transação, que é um....um comércio muito potente que nós temos hoje em dia né?”

\section{Falta de conhecimento do cliente para se medir}

E3 "Mas só que o cliente, ele não sabe se medir, ele não sabe os pontos certos exatos de tirar essa medida, qual a necessidade de folga ou não que tem que ser dada, enfim. Isso cria uma confusão muito grande na, nessa relação".

E6 "A única forma que a gente tem de fazer isso, é disponibilizar a tabela, as medidas de cada peça e a pessoa se medir. Aí onde que vem todo o erro? Primeiro começa a pessoa se medindo, como que ela vai fazer isso. Nem todo mundo vai ter...ou alguma pessoa próxima, ou uma avózinha que sabe medir. Porque tem que saber medir também, né?"

"Mas claro, tipo, as empresas poderia oferecer uma forma de como tirar medidas". 
Fator psicológico das medidas (vanity sizing)

E4 "Mas eu acho que ainda tem muito essa preocupação de tamanho. Se a gente tivesse um padrão exato, né, o P, o M, o G, ou GG, ou PP, eu acho que a gente venderia muito mais, mas o que limita o mercado nacional é justamente isso. O padrão de cada loja, né, ela usa, pra, pra satisfazer o seu cliente. Mas do que a forma real. Ah, tá, tem aquela, né, "Ah não, porque eu tô gordinha". Então ela faz um $\mathrm{P}$ grande pra satisfazer o cliente que se ache gordo. Né, que mais cheinha, essa é a diferença!"

\section{Compra de peças maiores para não errar}

E4 "Então, a gente gosta de roupa grudada no corpo. Só que por ter essas dificuldades de tamanhos, as pessoas tendem a comprar roupas mais largas. Até por causa da burocracia da compra e devolução".

\section{Problemas com devolução e troca}

E4 "Como na Europa, né, eu tenho bastante exemplo da Europa porque eu passei muito tempo lá. Então foram 15 anos de estudo de mercado, de pesquisa, de entender o consumidor, o que o consumidor quer. $\mathrm{E}$ então, assim, lá se tem chance de você comprar uma peça e você trocar em 28 dias, independente se você comprou ou não. Você fala: "Olha não rolou e pronto". No Brasil, você não tem isso. Então as pessoas no Brasil, tendem a comprar coisas mais largas porque não tem toda essa, esse trâmite pra devolução. Então mas é um mercado que tá consumindo muito, muito!"

\section{Padronização para aumentar a confiança do consumidor}

E4 "Totalmente, totalmente. (Então é você concorda comigo, você ter um padrão em todas as lojas, facilitaria então a compra, a confiança do consumidor?)"

\section{Aumentar a confiança do consumidor}

E5 “...eu acho que o grande problema aqui no, no Brasil, ele já é um ranço que vem do físico tá? A falta de confiança de quem tá vendendo o produto pro consumidor, que a gente tem diversos problemas que chegam a ir pra justiça né? De pessoas reclamando do consumo. Isso é transferido pro virtual, né? Tanto que têm pessoas comprando, não necessariamente roupa, mas comprando as vezes até celular e recebe um tijolo em casa. Então tem a confiabilidade, de onde ele tá adquirindo, é uma, uma questão né? Eu acho que é uma das piores questões, e já tem esse problema no mercado também em relação aos tamanhos, então eu acho que eles têm um grande receio de até piorar a situação ao adquirir essa roupa no meio virtual. Então eu acho que se aos poucos, a legislação, do consumo, for evoluindo, as pessoas passarem a acreditar um pouco mais no comércio de uma forma geral. E se o que é vendido em loja hoje, também for melhorando o atendimento, talvez o pessoal ganhe um pouco mais de confiança em adquirir isso a distância. Mas já cresceu bastante em relação há alguns anos atrás”.

\section{Tecnologia para diminuir a barreira}

E6 "Realidade aumentada?"

"É você ter as cabines....e você conseguir vender isso sem ser o produto físico, é....mas que na verdade quando a pessoa entra o corpo dela escaneada e projetada na tela. E você consegue colocar ali é....os modelos das roupas, e tipo assim, e automaticamente por uma leitura de dimensões, ele encaixa a roupa, e automaticamente você vai saber na sua tabela, qual, quais são as medidas".

“..pra reduzir mesmo, muito fácil, muito mais simples; a realidade aumentada”.

Caimento da roupa, além da modelagem

E6 "Porque, na modelagem não é só a opção tamanho também, tem a questão de caimento. Cada corpo se comporta de uma forma, então é muito complexo".

4) Você conhece o estudo realizado pelo Senai Cetiqt a respeito das medidas dos brasileiros e sua aplicação na modelagem? Qual é a sua opinião a respeito?

Dos 6 especialistas, somente um não conhecia o estudo realizado pelo SENAI Cetiqt. 2 especialistas participaram diretamente do estudo.

E3 "É... eu acho que é um estudo louvável né, é um estudo de uma...de uma importância muito grande, e de uma complexidade maior ainda, né? É...eu até lembro muito de uma fala de um dos responsáveis pela pesquisa, né, o professor Flávio Sabrá, onde ele dizia assim, que....a cada análise que eles iam fazendo dessas medições, que eram feitas em cidades, em Estados diferentes do Brasil, né, vinha aquele questionamento: meu Deus! Está cada vez pior né? A diversidade de medida tá ficando cada vez maior e isso tá complicando muito o estudo". 
"Ou seja, na verdade eles tiveram a ousadia de mexer numa coisa que é complexa de fato, né? E tiveram a oportunidade, por meio desse estudo de verificar e comprovar, como que essa variação, dos biótipos, da antropometria no nosso país, ela é gigante!”

"Ou seja, a pesquisa, ela vem se desmembrando, em diferentes etapas e as pessoas estão podendo recorrer a ela pra buscar subsídios pra desenvolver os seus projetos, né. Então eu acho assim, que a gente tem um longo caminho ainda a ser trilhado, mas o pontapé inicial já foi dado, né, com esse projeto que está aí. E vamos continuar participando né, e contando com resultados cada vez mais satisfatórios na que possam atender as demandas, né, do nosso mercado consumidor".

\section{Não conhecia o estudo}

E4 "Ouvi assim, muito por alto, nunca entendi muito como ele funcionava. Da onde saiu esses princípios, sabe, do Senac, desse estudo. Ele foi baseado em quê? Eu não poderia responder porque eu não sei”.

\section{Aumento do grau de assertividade}

E6 "É, assim, eu acho, pelo menos hoje vai ser uma coisa bem mais assertiva, né? Você vai ter, talvez, as pessoas que não consigam tipo, trabalhar com medidas e queiram se basear numa tabela. Pelo menos vai diminuir muito a chance de erro pra quem tá produzindo também".

\section{Tabelas mais atuais para acompanhar mudança nos corpos dos brasileiros}

E6 "E vamos combinar, que hoje o corpinho não é mais a mesma coisa, né? Tipo muita coisa mudou e muito mais misturas aconteceram dentro do Brasil. Acho maravilhoso que estão fazendo".

\section{5) Como você vê a importância na prática desse estudo? Quais benefícios ele pode trazer?}

\section{Colocar em prática a pesquisa}

E1 "Então, cê não é só fazer a pesquisa e ela ir para uma prateleira. Ela ser...fazer a pesquisa, fazer é....os testes para saber se aquilo ali está dando certo, é...é....fazer uma, uma, um comprobatório daquilo ali e você melhorar a capacidade produtora".

"Pra você melhorar o atendimento ao usuário final, que ele é o fundamental.

"Que hoje você pode numa loja A, como a gente começou a conversar, e o 42 ser completamente diferente do 42 da marca $\mathrm{C}$, porque eu quero atender...."

"E eu também entendo com que é o perfil daquele consumidor, eu tenho que entender quem é aquele usuário final".

"Eu acredito que a pesquisa ela vá ajudar é pra melhorar o....a rentabilidade. A gente tem que pensar é em negócio, né. Como é que aquilo ali melhora a cadeia como um todo".

"Isso... Ou outros países mandam pra gente (tabelas de medidas), ou você vai naquela tentativa de erro e acerto. Que aí você perde tempo e você é....perde credibilidade. E aí você também tem investimento as vezes que aí você não consegue ter uma reposição financeira desse investimento quanto pesquisa ou é....nem falo do investimento da pesquisa, mas assim aquele empreendedor que acreditou numa tabela que errou, ele está perdendo ali investimento, tanto de matéria prima quanto de comércio. Importante sobre essa ótica”.

\section{Economia de material}

E1 "Mas eu sou o que produz, vou dar um exemplo, era um exemplo que eu gostava e gosto de dar, vamos supor que a gente chegue uma, é... um resultado que ...calça masculina, as pernas dos homens, giram em torno de $1,10 \mathrm{~m}$. Porque que se faz de um $1,2 \mathrm{~m}$ ? Qual é o grau de acerto que você precisa ter né? Não tô dizendo nem para você ter três alturas de perna não, mas você vai ter uma altura de perna só, mas se eu faço 1,20 e a maior frequência, a maior frequência é um $1,10 \mathrm{~m}$ eu tô perdendo $10 \mathrm{~cm}$ em calça produzida no Brasil".

E2 "O estudo, ele é fundamental para que as marcas se mantenham no mercado hoje. Eu preciso desse estudo pra poder montar a minha tabela dentro da empresa, dentro dessa tabela, eu poder fazer a modelagem, em seguida a graduação e por fim, a comercialização. Então, padronizar, é peça fundamental pra comercialização. Porque ela envolve todo o processo de desenvolvimento de um produto. Até a comercialização".

\section{Satisfação do consumidor}

E1 "É...tanto esse estudo específico do Senai Cetiqt, como outro que a gente tem...outros é....universidades ou centros de pesquisa, são, no meu ponto de vista, todos importantes para você melhorar o grau de inovação, melhorar o grau de assertividade do empreendedor para atender o cliente final". 
E3 "É....acho que a importância desse estudo, ela está exatamente no fato da necessidade que a gente já observa, né, há anos, de que o nosso mercado não está atendendo a expectativa do consumidor, ou seja, a gente tem uma demanda muito grande nesse mercado, a gente tem um mercado promissor, um mercado gigantesco que movimento milhões na nossa economia né?"

"E por outro lado, a gente tá tentando o tempo todo buscar a satisfação desse consumidor, que é o grande responsável por tudo isso né? Então acho que a importância desse estudo é de estar centrado exatamente nisso, de buscar subsídios para que a gente possa atingir de fato uma padronização mínima, né, que o mercado...em todo o Brasil, vamos tentar, né generalizar dessa forma, que ele possa atender essa demanda, e oferecer produtos que tenham uma aceitação cada vez maior por esse, esse público né? E eu acho que os benefícios que esse estudo pode trazer, é exatamente isso né? É favorecer e otimizar o tempo de produção nas confecções de vestuário né?"

\section{Padronização entre marcas mantendo cada uma sua peculiaridade}

E3 "E que cada vez mais as marcas mantenham um diálogo entre elas né? Obviamente cada uma com seu público-alvo, cada uma com suas peculiaridades, cada uma trabalhando com o seu material. Ou seja, trazendo os seus diferenciais mas que qualquer pessoa, né, esse qualquer entre aspas, obviamente né? Que queira fazer parte daquele público, que pelo menos por meio de um oferecimento de uma modelagem que esteja dentro de uma normatização, ela seja possível né, se ingressar nesse público-alvo independente de qual marca seja”.

\section{Esclarecimento ao consumidor quanto as medidas adotadas pela marca}

E3 “Ou seja, trazendo os seus diferenciais mas que qualquer pessoa, né, esse qualquer entre aspas, obviamente né? Que queira fazer parte daquele público, que pelo menos por meio de um oferecimento de uma modelagem que esteja dentro de uma normatização, ela seja possível né, se ingressar nesse público-alvo independente de qual marca seja".

\section{Defendendo as costureiras para tirarem as medidas do estudo antropométrico}

E4 "Então assim, acho que, essa pesquisa é importante? É importante. Mas eu acho que a gente tinha que usar o nosso mecanismo, né, o nosso mecanismo que a gente usou, que é a nossa indústria, que é o nosso artesanato, da nossa mão de obra. Eu acho que, que é , que é um investimento, que é na verdade, ele é muito minucioso. Assim, é um estudo, de partículas, ou quase, né? É tudo muito certinho pra ajeitar, e que cara, e a gente tem a prática que o mundo conhece, que é, são as roupas feitas sob medida. Você vai e mede, então eles podiam ter isso em vários estados e terem feito essa pesquisa com as costureiras, as velhas que estão fazendo há muito mais tempo, eles teriam o mesmo resultado".

"A gente tem as nossas costureira. Não é um mecanismo de indústria eletrônico, né? Até porque a gente não tem esse mecanismo no Brasil, a nossa indústria, o nosso maquinário, eles são muito velhos, arcaicos, Se fosse em outro país, tudo bem. Eles têm a tecnologia para poder comparar isso, a gente não tem essa tecnologia, pra continuar esse segmento do corpo escaneado, preciso".

"Porque aí chega lá na frente você vai e cai pras costureiras. Elas não vão entender que foi feita uma pesquisa no Brasil, que no Nordeste é assim, que...é só olhar gente! É uma prática de olhar, você olha e você reconhece. Eu acho que poderia ter sido melhor se pudesse ter sido treinado, pra esse olhar mudar diante dessa pesquisa. E não pra trazer um elemento, que seria mais fácil né, no olhar deles, seria uma máquina, num scan, sei lá".

\section{Diminuição do número de devoluções}

E5 "Olha, em primeiro, em primeiríssimo lugar, reduzir o retorno. Isso traz um, um, um problema logístico, pra empresas, enorme. Há empresas que chegam a $40 \%$ de devoluções. Isso é um prejuízo enorme...”

"(Falando sobre o site Asos) ....informam, que eles tiveram uma, uma redução justamente na devolução dos produtos deles, beirando $60 \%$. Isso é uma coisa fantástica, né? Se eles conseguiram reduzir isso também, eles também demonstram medidas, né, de corpo, dos produtos deles, eles demonstram, é, medidas de produtos prontos, pros clientes. E isso de alguma forma ajuda a reduzir esses problemas".

"Acho que o principal é a venda com mais segurança, de redução de retorno deles. Eu acho que isso é o mais concreto impossível, que seria com esse tipo de estudo".

E6 "Então assim pra pequenos produtores, e até pra indústria de modo geral, isso acaba reduzindo a chance de, de descarte, né? Porque as vezes a pessoa pode produzir, tipo, 10 mil camisas que não entra em ninguém. Posso ser uma porcaria. Pensando num viés sustentável isso é a melhor possível".

"É tipo, vai ser ótimo pra quem é da indústria e que segue esses padrões, e precisa dessas medidas. E...não necessariamente, talvez tenha um pequeno, é...produtores que não queiram vender quantidade, mas também, quer seguir ali uma tabelinha, pra conseguir vender o certo, né? Não posso falar também que tipo, toda indústria é...é...tem um viés maléfico e quer tipo, só tirar lucro". 
Benefício para a indústria e o pequeno produtor

E6 "É....então assim, isso vai ser ótimo pra, pra pequenos produtores. E pessoas que realmente não têm acesso a essa informação. Ou acesso a tipo, esse intelecto de observar o público, porque não é uma coisa fácil. Não é uma coisa, não é qualquer um que faz assim: "Ah, vou abrir uma empresa." E vou olha pro meu público, vou entender qual é o corpinho de cada um. Não, isso exige, tipo assim, uma sagacidade, um clique, pra falar assim: "Cara, aí, vou olhar pro meu público e saber o que que eu vou fazer pra cada um."

"Alavancar, acabando alavancando né, a...a indústria, porque você consegue vender e você consegue fidelizar cliente, porque assim, querendo ou não você consegue vender um produto que se adequa ao corpo dele né? Acho que são essas, essas questões pra, desse estudo. E que, até porque realmente já tá....outra coisa que, tá precisando de novas medidas né? Pras pessoas se guiarem, porque, o bumbum da brasileira hoje, não é o mesmo não, não é não!"

\section{Tabela para interferências estéticas}

E6 "Isso eu acho engraçado, porque eu não sei nem como que eles vão conseguir tabelar isso, porque....na verdade acho que deveria existir um, uma tabela pra quem faz interferências no corpo. Porque assim, tem algumas coisas que são tipo assim, irreais! Você não vai encontrar corpos, tipo corpos dessa forma, assim, com tanta frequência pra você conseguir encaixar num padrão. Tá aí devia alguém fazer alguma coisa, corpo de siliconado. Tabela de corpo de siliconado".

\section{6) O que mais você teria a comentar sobre o assunto?}

E2 "Então, essa tendência (e-commerce), ela cada vez mais ela busca a necessidade de se ter um padrão de medidas. Né, é, porque não tem como vender, a distância, que é uma tendência mundial, não temos como vender a distância, se não trabalharmos em cima de um padrão de medidas".

"Quando perceberem que pra elas se manterem no mercado elas vão precisar ter esse padrão bem claro e bem definido dentro de seus produtos".

E4 “...em pouco lugares do mundo você consegue encontrar marcas brasileira, por causa da ineficiência da modelagem. Então o que acontece? A Osklen, é única que vende fora, que tem lojas, por quê? Porque eles foram muito inteligentes, na forma como, de desenvolvimento de coleção. Eles usam as modelagens, eles fizeram uma pesquisa enorme sobre o mercado internacional, antes de abrirem as lojas. Eles tiveram que readaptar a forma deles, pra que funcionassem como negócio. Né?

"Mas assim todos os brasileiros que moram fora do Brasil e trabalham com moda, tá na área de pesquisa. A gente não tem a mão de obra, a gente não tem esses formantes, atuantes que são os estilistas. Né? Quando você uma faculdade, a minha faculdade na Inglaterra, cara, no primeiro ano, quando eu botei o pé até o final do ano, eu só costurei, só fiz modelagem, e moulage. Foi só o que eu fiz, claro que tinha os teóricos que complementam, eles seguem junto, a matéria. $\mathrm{O}$ teórico ele não tomou conta do prático, sabe, eles andaram paralelos. Os dois eram importantes, eu acho que no Brasil não tem isso, é muito teórico demais. E a prática ela é perversa, porque quando esses estudantes eles chegam no mercado, eles não sabem nada, eles não são formado pra isso. Eu conheço pessoas, estilistas que não sabem colocar um botão sabe? E como que essas pessoas podem se chamar, né? Eu me coloco, eu sou uma, eu sou uma costureira, mais refinada. Mas eu acho que essa coisa do estilismo né, hoje em dia todo mundo quer ser estilista, porque virou moda".

"Então tem uma deficiência muito grande no mercado interno, né? De aperfeiçoamento. Eu acho que a gente precisa rever os nossos conceitos, porque eu acho que as melhores, os melhores, os formadores do Brasil, são os artesão. É essa mão de obra. Essas pessoas sabem sim, porque elas são da prática, elas fazem na prática. Não há teoria por trás do que elas fazem. Eu acho que a moda hoje em dia, essa moda moderna, que a gente faz, esse é o grande problema. É porque as pessoas, elas não se qualificam, porque elas acham que não há "precisão" (necessidade) da qualificação".

E5 "A gente tá caminhando "pruma" evolução tecnológica, a gente tem discutido até bastante a esse respeito. E dentro da indústria a gente está caminhando também, pro que eles chamam de indústria 4.0, na indústria têxtil, que é cada vez mais tornar a parte de produção robotizada, então a gente já tem alguns casos fora, em que a pessoa, ela escolhe o modelo, ela escolhe o tecido, ela escolhe a cor. Ela é medida, muitas vezes essa medição, ela pode ser feita até via celular. Existem alguns scanners que pode montar na sua casa, eles mostram como. Tecnologias similares que o pessoal usa em $x$-box, né? E é sim, em uma semana, as vezes menos, a roupa chega na, na casa da pessoa, prontinha com um custo bem razoável, pro tipo de produto, né? É uma realidade, está batendo aí à porta. O Brasil, ele vai ter que correr atrás de alcançar isso também, também senão ele vai perder muito mais mercado do que ele vem perdendo hoje. Os asiáticos, eles tinham uma correlação de produto vagabundo, né? De comprar a custo baixíssimo, que hoje já não é mais a realidade. Hoje já encontra peças de qualidade, aqui no mercado com um preço razoável, então eles já não mais, tão com relação, assim, com coisas de baixa qualidade. Eles, eles souberam correr atrás, nesses últimos anos, coisa que aqui no Brasil o pessoal ainda tá, é, galgando, né? Eles...num , num chegou lá. Então eu acho 
que, medidas como essa, de conhecer melhor o corpo, pra quem a empresa, ela quer atender. Melhorar sua parte produtiva, né? Esse, esse tipo de, de ações é que vão fazer com que a gente se diferencie no mercado, e possa atender melhor esse novo perfil de consumidor, que é um cara que não, não vai ser mais enganado. Que ele vai correr atrás do prejuízo, se ele se sentir lesado de alguma forma".

E6 "Eu não vejo hoje mais as pessoas com tanto medo de comprar na internet. Existem? Existem. Mas...dentro, hoje, do que a gente vive, a...a chance de erro, ou a chance de tipo assim, dá muito problema, tipo, de dá muito problema, da empresa não querer trocar..."

"As pessoas estão mais confiantes. Até porque assim, ninguém quer muito meio que levar um tiro no pé. Porque assim, de fato isso vai ser um problema se a pessoa não devolver".

"É...mas, eu acho que sim, o maior problema tá, tipo, ainda em cidades do interior que tem muito medo de coisas diferentes. Mas assim, Rio de Janeiro, capitais, grandes metrópoles assim, eu vejo eles comprando assim, de forma tranquila e com aquela expressão: “Ah se eu não gostar eu devolvo!” Porque realmente funciona essa parte de devolução e de troca. Sinceramente, eu não consigo pensar numa empresa, assim que eu ouvi falar sobre os problemas de troca. Nem grandes, nem pequenas, porque eu tenho vários amigos que fazem produção assim, tem sua loja pequena e....faz essa parte de devolução, de troca..."

"O maior problema só, tipo, da compra disso, é conseguir reduzir essa chance de erros, ou tipo de...da pessoa não gostar. Não gostar, vai ser muito assim, estético, colocou no corpo e não gostei. Mas tipo chance de erro da modelagem, ou alguma coisa do próprio produto em si. Fora isso, acho que a gente já tá no caminho, até muito avançado. Muito avançado".

"Tanto é que tipo, tem muitas aí fechando pra vender só online. Muita gente fechando loja, só pra vender online. Mas barato... porque o espaço físico é muito caro".

"Então tipo assim, você já meio que, abraça aquela pessoa pra se sentir confortável. "Beleza, vou comprar aqui, mas eles tão ali prontamente pra mim." Porque tem muitos que assim, só vamos vender, sei lá, Dafiti da vida. Se tiver uma parte lá, de tipo assim, "Estou desesperado, o que que eu faço?", é tanta coisa, tanta informação que você não acha nada, né? É...mas aí ele tá criando esse sistema, tipo, ele consegue abraçar a pessoa, e a pessoa ficar confortável. "Ok, vou comprar mas...tô vendo que eles estão ali todo o tempo ali se colocando..." "Ótimo, vem aqui, a gente pode tá te ajudando. A gente vai tá aqui paradinho...se der alguma m aí, cê vem aqui e nos procure." Tipo, são formas de ajudar. Porque quanto mais você se faz presente, pra pessoa, mesmo, tipo, se for uma....tela. Mais confortável você fica pra comprar". 
Tabela completa da análise de conteúdo da entrevista com

\section{especialistas de moda}

\begin{tabular}{|c|c|c|c|c|c|c|c|c|}
\hline \multirow{2}{*}{ Tema/Categoria } & \multicolumn{6}{|c|}{ Frequencia por Especialistas } & \multirow{2}{*}{$\begin{array}{c}\text { Total de } \\
\text { ocorrências }\end{array}$} & \multirow{2}{*}{$\begin{array}{c}\text { \% sobre o } \\
\text { total de }\end{array}$} \\
\hline & E1 & E2 & E3 & E4 & E5 & E6 & & \\
\hline Padronização & & & & & & & 41 & $100,00 \%$ \\
\hline $\begin{array}{l}\text { Referências base para a } \\
\text { construção do vestuário }\end{array}$ & 3 & 1 & 2 & - & 5 & - & 11 & $26,83 \%$ \\
\hline $\begin{array}{l}\text { O que é padronização? - } \\
\text { como conceituar o termo }\end{array}$ & 4 & - & - & - & - & - & 4 & $9,76 \%$ \\
\hline $\begin{array}{l}\text { Impossibilidade de } \\
\text { padronização devido a } \\
\text { grande diversidade de } \\
\text { corpos }\end{array}$ & - & - & - & - & - & 1 & 1 & $2,44 \%$ \\
\hline Diversidade nos tamanhos & - & - & - & - & - & 1 & 1 & $2,44 \%$ \\
\hline $\begin{array}{l}\text { Respeito a individualidade } \\
\text { de cada marca }\end{array}$ & - & - & 1 & - & 1 & 1 & 3 & $7,32 \%$ \\
\hline Normatização & - & - & 1 & - & - & - & 1 & $2,44 \%$ \\
\hline $\begin{array}{l}\text { Demanda do consumidor } \\
\text { por uma padronização }\end{array}$ & - & - & 1 & - & - & - & 1 & $2,44 \%$ \\
\hline $\begin{array}{l}\text { Necessidade de } \\
\text { padronização }\end{array}$ & - & 6 & 2 & 3 & - & - & 11 & $26,83 \%$ \\
\hline $\begin{array}{l}\text { Padronização fundamental } \\
\text { para comercialização e } \\
\text { manutenção das marcas no } \\
\text { mercado }\end{array}$ & - & 2 & - & - & - & - & 2 & $4,88 \%$ \\
\hline Padronização & - & 1 & - & - & - & - & 1 & $2,44 \%$ \\
\hline $\begin{array}{l}\text { Possiblidade de } \\
\text { padronização }\end{array}$ & - & 1 & - & 1 & - & - & 2 & $4,88 \%$ \\
\hline Desnecessário um padrão & - & - & - & - & - & 1 & 1 & $2,44 \%$ \\
\hline $\begin{array}{l}\text { Revisão da qualificação dos } \\
\text { profissionais de modelagem }\end{array}$ & - & - & - & 2 & - & - & 2 & $4,88 \%$ \\
\hline Informação & & & & & & & 42 & $100,00 \%$ \\
\hline $\begin{array}{l}\text { Conhecer o público / } \\
\text { Conhecer melhor o } \\
\text { consumidor }\end{array}$ & 5 & 1 & - & - & - & - & 6 & $14,29 \%$ \\
\hline $\begin{array}{l}\text { Feedback constante dos } \\
\text { consumidores }\end{array}$ & - & 1 & - & - & - & - & 1 & $2,38 \%$ \\
\hline $\begin{array}{l}\text { Informação e transparência } \\
\text { para o consumidor }\end{array}$ & 4 & 5 & 3 & 2 & 4 & 5 & 23 & $54,76 \%$ \\
\hline $\begin{array}{l}\text { Falta de conhecimento do } \\
\text { cliente para se medir }\end{array}$ & - & 1 & 1 & - & - & 2 & 4 & $9,52 \%$ \\
\hline Pesquisas na área & 3 & - & - & - & - & - & 3 & $7,14 \%$ \\
\hline $\begin{array}{l}\text { Colocar em prática a } \\
\text { pesquisa }\end{array}$ & 1 & - & - & - & 4 & - & 5 & $11,90 \%$ \\
\hline Indústria & & & & & & & 18 & $100,00 \%$ \\
\hline Impacto na indústria & 1 & - & 1 & 1 & - & 1 & 4 & $22,22 \%$ \\
\hline Produção em massa & - & - & - & - & - & 1 & 1 & $5,56 \%$ \\
\hline Retorno para a marca & - & 1 & - & - & - & - & 1 & $5,56 \%$ \\
\hline Aumento da rentabilidade & 2 & - & - & - & - & - & 2 & $11,11 \%$ \\
\hline Economia de material & 1 & - & - & - & - & 1 & 2 & $11,11 \%$ \\
\hline Benefício para a indústria & - & - & - & - & - & 3 & 3 & $16,67 \%$ \\
\hline $\begin{array}{l}\text { Diminuição do número de } \\
\text { devoluções }\end{array}$ & - & - & - & - & 3 & - & 3 & $16,67 \%$ \\
\hline $\begin{array}{l}\text { Ineficiência da modelagem } \\
\text { dificultando a exportação }\end{array}$ & 1 & - & - & - & - & - & 1 & $5,56 \%$ \\
\hline Atraso do Brasil em relação & & & & & 1 & & 1 & ᄃ c co/ \\
\hline
\end{tabular}




\begin{tabular}{|c|c|c|c|c|c|c|c|c|}
\hline \multirow{2}{*}{ Tema/Categoria } & \multicolumn{6}{|c|}{ Frequencia por Especialistas } & \multirow{2}{*}{$\begin{array}{l}\text { Total de } \\
\text { ocorrências }\end{array}$} & \multirow{2}{*}{$\begin{array}{c}\% \text { sobre o } \\
\text { total de }\end{array}$} \\
\hline & E1 & E2 & E3 & E4 & E5 & E6 & & \\
\hline Online e offline & & & & & & & 11 & $100,00 \%$ \\
\hline $\begin{array}{l}\text { Compra de peças maiores } \\
\text { para não errar }\end{array}$ & - & - & - & 1 & - & - & 1 & $9,09 \%$ \\
\hline $\begin{array}{l}\text { Tecnologia para diminuir a } \\
\text { barreira }\end{array}$ & - & - & - & - & - & 3 & 3 & $27,27 \%$ \\
\hline Tecnologia ajudando a moda & - & - & - & - & 1 & - & 1 & $9,09 \%$ \\
\hline $\begin{array}{l}\text { Caimento da roupa, além da } \\
\text { modelagem }\end{array}$ & - & - & - & - & - & 1 & 1 & $9,09 \%$ \\
\hline $\begin{array}{l}\text { Diminuição do medo de } \\
\text { comprar online }\end{array}$ & - & - & - & - & - & 2 & 2 & $18,18 \%$ \\
\hline $\begin{array}{l}\text { Aumento de lojas online por } \\
\text { causa do custo da loja física }\end{array}$ & - & - & - & - & - & 1 & 1 & $9,09 \%$ \\
\hline $\begin{array}{l}\text { Problemas com devolução e } \\
\text { troca }\end{array}$ & - & - & - & 1 & - & - & 1 & $9,09 \%$ \\
\hline $\begin{array}{l}\text { Diversidade nos tamanhos e } \\
\text { a impossibilidade de } \\
\text { experimentar }\end{array}$ & - & - & 1 & - & - & - & 1 & $9,09 \%$ \\
\hline Diversidade brasileira & & & & & & & 12 & $100,00 \%$ \\
\hline $\begin{array}{l}\text { Diversidade dos corpos das } \\
\text { brasileiras }\end{array}$ & 1 & - & 3 & 1 & 1 & 1 & 7 & $58,33 \%$ \\
\hline $\begin{array}{l}\text { Mudança do corpo do } \\
\text { brasileiro }\end{array}$ & 1 & - & - & - & 2 & - & 3 & $25,00 \%$ \\
\hline $\begin{array}{l}\text { Tabelas mais atuais para } \\
\text { acompanhar mudança nos } \\
\text { corpos dos brasileiros }\end{array}$ & - & - & - & - & - & 1 & 1 & $8,33 \%$ \\
\hline $\begin{array}{l}\text { Tabela para interferências } \\
\text { estéticas }\end{array}$ & - & - & - & - & - & 1 & 1 & $8,33 \%$ \\
\hline Grau de acerto & & & & & & & 13 & $100,00 \%$ \\
\hline $\begin{array}{l}\text { Melhora do grau de } \\
\text { assertividade }\end{array}$ & 4 & 1 & 1 & - & - & 3 & 9 & $69,23 \%$ \\
\hline $\begin{array}{l}\text { Melhora do grau de } \\
\text { assertividade usando } \\
\text { moulage }\end{array}$ & - & - & - & 4 & - & - & 4 & $30,77 \%$ \\
\hline Confiança & & & & & & & 8 & $100,00 \%$ \\
\hline $\begin{array}{l}\text { Aumentar a confiança do } \\
\text { consumidor }\end{array}$ & - & - & - & 1 & 1 & - & 2 & $25,00 \%$ \\
\hline $\begin{array}{l}\text { Confiança no produto que } \\
\text { está comprando }\end{array}$ & - & 1 & - & - & - & - & 1 & $12,50 \%$ \\
\hline $\begin{array}{l}\text { Satisfação do } \\
\text { usuário/consumidor }\end{array}$ & 2 & - & 2 & - & - & - & 4 & $50,00 \%$ \\
\hline $\begin{array}{l}\text { Apoio ao consumidor para } \\
\text { ele se sentir mais seguro, } \\
\text { mesmo que seja online }\end{array}$ & - & - & - & - & - & 1 & 1 & $12,50 \%$ \\
\hline Fator psicológico das medidas & & & & & & & 10 & $100,00 \%$ \\
\hline $\begin{array}{l}\text { Influência do fator } \\
\text { psicológico das medidas }\end{array}$ & 2 & 1 & - & 3 & 2 & 2 & 10 & $100,00 \%$ \\
\hline Estudo SENAI Cetiqt & & & & & & & 4 & $100,00 \%$ \\
\hline Complexidade do estudo & - & - & 3 & - & - & - & 3 & $75,00 \%$ \\
\hline Não conhecia o estudo & - & - & - & 1 & - & - & 1 & $25,00 \%$ \\
\hline
\end{tabular}




\section{Apêndice 3}

Materiais do Teste de Usabilidade 
Termo de consentimento livre e esclarecido: teste de usabilidade
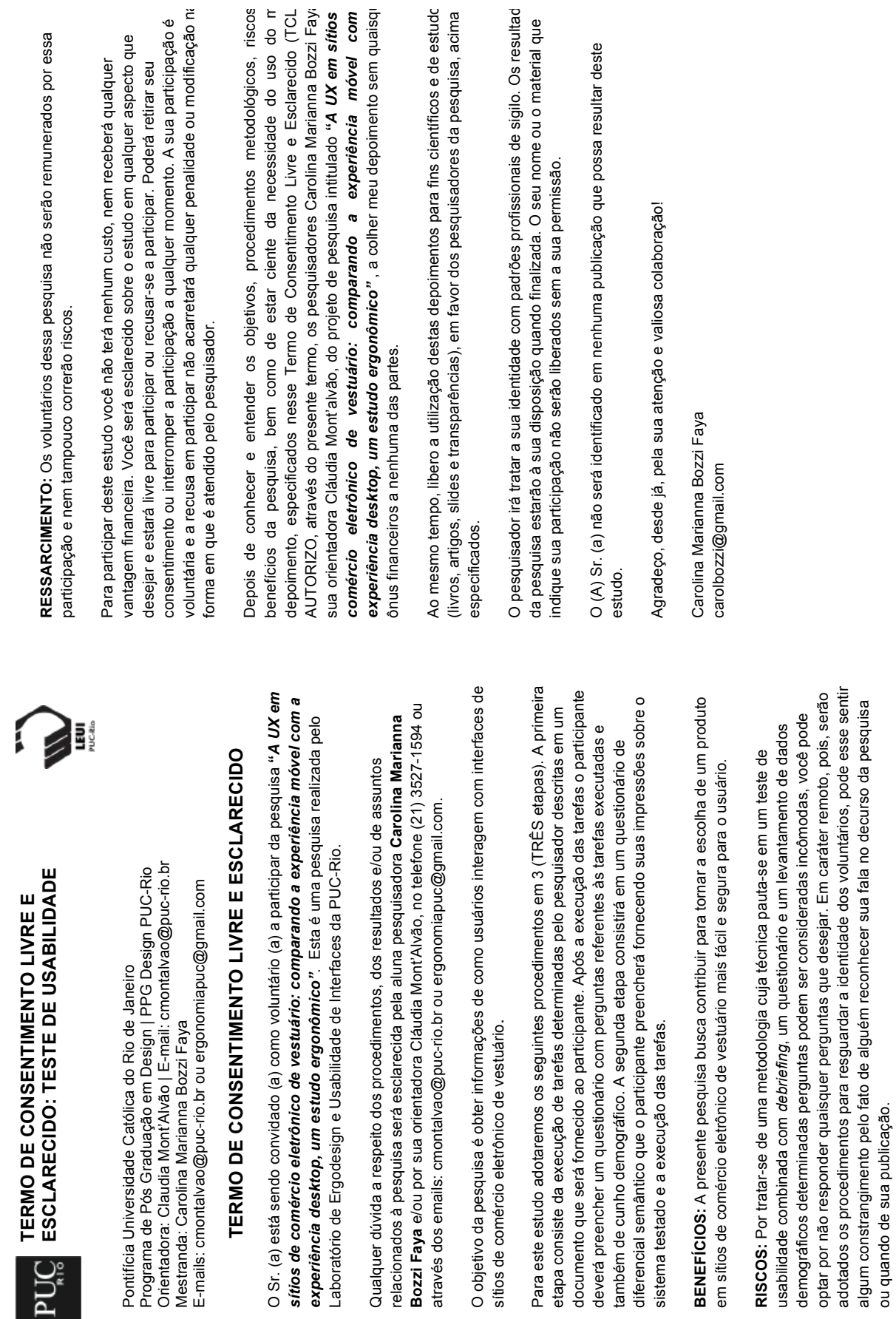


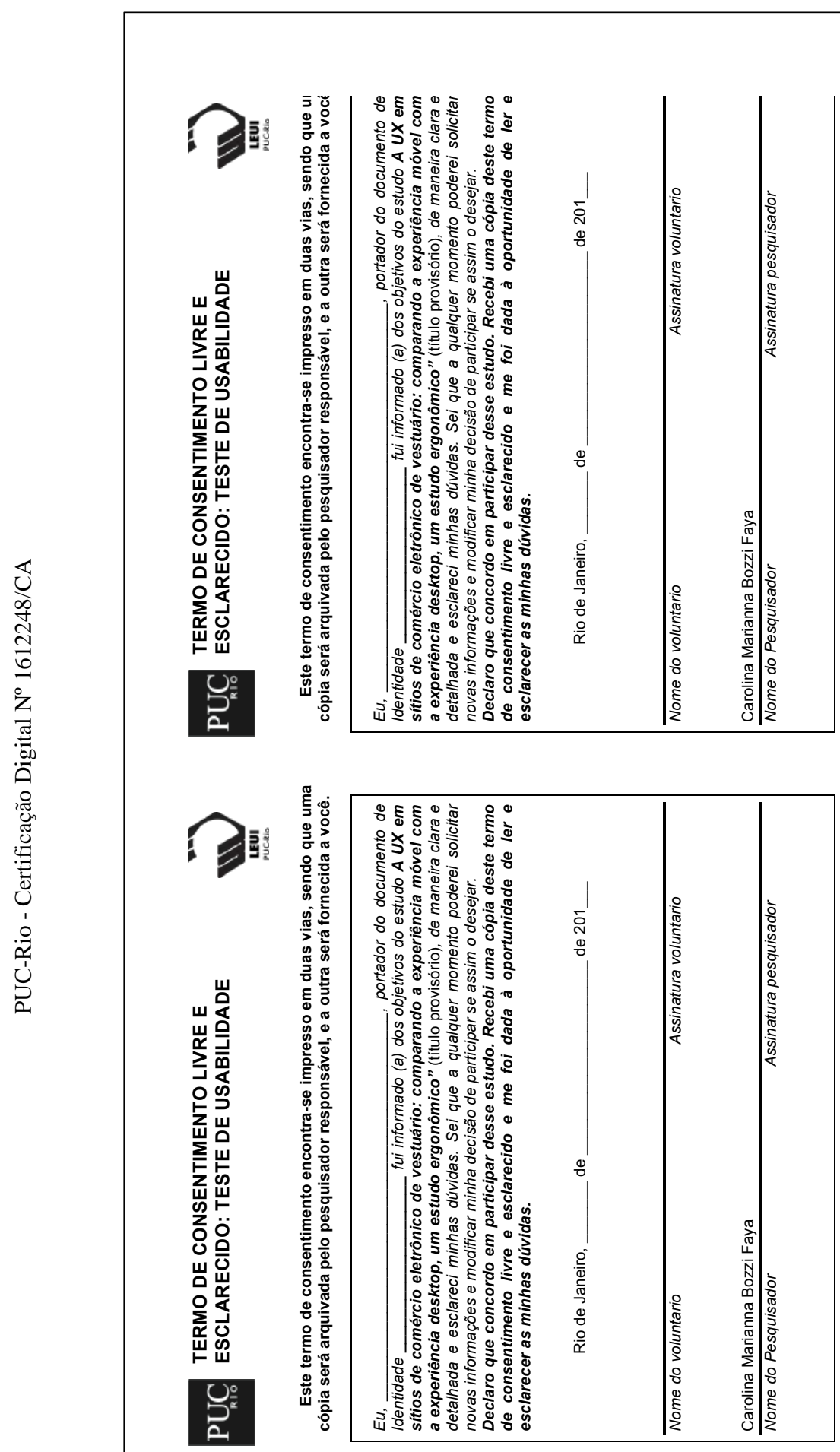


Debriefing

DEBRIEFING

Já navegou no dafiti.com: $\operatorname{Sim} \square$ Não $\square$

Teste realizado em:

Desktop/laptop $\square$

Smartphone $\square$ Modelo:

1. Nome:

2. Gênero: Feminino $\square \quad$ Masculino $\square \quad$ Outros $\square$

3. Idade:

4. Grau de escolaridade:

5. Ocupação:

6. Cidade e estado onde mora?

7. Qual é a sua frequência de compras on-line?
$\square$ Mais de $2 x /$ mês
$\square 1 \mathrm{x}$ a cada 4 meses
$\square 2 x / m e ̂ s$
$1 \times$ a cada 6 meses
$\square 1 \mathrm{x} / \mathrm{mês}$
$\square$ Menos $1 x$ a cada 6 meses
$\square$ 1x a cada 2 meses
$\square$ Não compro on-line

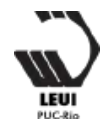

8. As informações disponíveis no sítio para a sua compra foram:

Suficientes $\quad \square \quad \square \quad \square \quad$ Insuficientes

9. A tabela/guia de medidas contém informações claras?

$\operatorname{Sim} \square$ Não $\square$ Porque? 
10. Você sente-se segura em relação as informações sobre o caimento da peça?

Sim $\square$ Não $\square$ Porque?

11. Com base nas informações disponíveis você tem segurança de que o tamanho escolhido está correto?

$\operatorname{Sim} \square$ Não $\square$ Porque?

12. As políticas de troca da loja estão claras?

$\operatorname{Sim} \square$ Não $\square$

13. Geralmente, quando você compra on-line o preço é um fator decisório de compra? $\operatorname{Sim} \square$ Não $\square$

14. Quais outros fatores influenciam sua decisão de compra? 
Análise do debriefing por tema (frequência de citaão)

\begin{tabular}{|c|c|c|c|c|}
\hline \multirow{2}{*}{$\begin{array}{l}\text { Quais outros fatores influenciam sua decisão de } \\
\text { compra? (Além do preço) }\end{array}$} & \multicolumn{4}{|c|}{ FREQUÊNCIA (\# MENÇÕES) } \\
\hline & $\begin{array}{c}\text { GRUPO A } \\
\text { DESKTOP/LAPTOP }\end{array}$ & $\%$ & $\begin{array}{c}\text { GRUPO B } \\
\text { SMARTPHONE }\end{array}$ & $\%$ \\
\hline COMODIDADE/PRATICIDADE & 13 & $18 \%$ & 12 & $22 \%$ \\
\hline VARIEDADE & 2 & $3 \%$ & 2 & $4 \%$ \\
\hline AVALIAÇÕES & 3 & $3 \%$ & 2 & $4 \%$ \\
\hline FINANCEIRO & 16 & $21 \%$ & 14 & $25 \%$ \\
\hline CONFIANÇA & 5 & $3 \%$ & 2 & $4 \%$ \\
\hline ENTREGA & 9 & $12 \%$ & 8 & $15 \%$ \\
\hline DISPONIBILIDADE DO PRODUTO & 5 & $11 \%$ & 7 & $13 \%$ \\
\hline CARACTERIISTICAS DO PRODUTO & 5 & $5 \%$ & 3 & $5 \%$ \\
\hline POLÍTICA DE TROCA & 2 & $2 \%$ & 1 & $2 \%$ \\
\hline RECURSOS DO SITE & 4 & $2 \%$ & 1 & $2 \%$ \\
\hline OUTROS & 2 & $5 \%$ & 3 & $5 \%$ \\
\hline \multirow[t]{2}{*}{ Total } & 66 & $83 \%$ & 55 & $100 \%$ \\
\hline & \multicolumn{4}{|c|}{ FREQUÊNCIA (\# MENÇÕES) } \\
\hline Como você escolheu o seu tamanho & $\begin{array}{c}\text { GRUPO A } \\
\text { DESKTOP/LAPTOP }\end{array}$ & $\%$ & $\begin{array}{l}\text { GRUPO B } \\
\text { SMARTPHONE }\end{array}$ & $\%$ \\
\hline HISTÓRICO DE COMPRAS & 19 & $63 \%$ & 25 & $83 \%$ \\
\hline USOU RECURSOS DO SITE & 4 & $13 \%$ & 4 & $13 \%$ \\
\hline USOU AMBOS (HISTÓRICO E RECURSOS) & 4 & $13 \%$ & - & \\
\hline OUTROS & 3 & $10 \%$ & 1 & $3 \%$ \\
\hline \multirow[t]{2}{*}{ Total } & 30 & $100 \%$ & 30 & $100 \%$ \\
\hline & \multicolumn{4}{|c|}{ FREQUÊNCIA (\# MENÇõES) } \\
\hline A tabela de medidas continha informações claras? Não. & $\begin{array}{c}\text { GRUPO A } \\
\text { DESKTOP/LAPTOP }\end{array}$ & $\%$ & $\begin{array}{l}\text { GRUPO B } \\
\text { SMARTPHONE }\end{array}$ & $\%$ \\
\hline NÃO FOI LOCALIZADA & 3 & $25 \%$ & 5 & $50 \%$ \\
\hline NÃO TEM AS INFORMAÇÕES NECESSÁRIAS & 6 & $50 \%$ & 3 & $30 \%$ \\
\hline OUTROS & 3 & $25 \%$ & 2 & $20 \%$ \\
\hline Total & 12 & $100 \%$ & 10 & $100 \%$ \\
\hline & FREQU & |ÊNCIA (\#) & (\# MENÇÕES) & \\
\hline A tabela de medidas continha informações claras? Sim. & $\begin{array}{c}\text { GRUPO A } \\
\text { DESKTOP/LAPTOP }\end{array}$ & $\%$ & $\begin{array}{l}\text { GRUPO B } \\
\text { SMARTPHONE }\end{array}$ & $\%$ \\
\hline INFORMAÇÕES CLARAS MAS QUE DEIXAM DÚVIDAS & 1 & $6 \%$ & 2 & $10 \%$ \\
\hline FACILIDADE & - & - & 3 & $15 \%$ \\
\hline OFERECIA INFORMAÇÕES ADEQUADAS & 13 & $72 \%$ & 12 & $60 \%$ \\
\hline INFORMAÇÕES CLARAS MAS NÃO SÃO PRÁTICAS & 1 & $6 \%$ & 1 & $5 \%$ \\
\hline SEGURANÇA NAS INFORMAÇÕES & 1 & $6 \%$ & 1 & $5 \%$ \\
\hline FAMILIARIEDADE & 0 & $0 \%$ & 1 & $5 \%$ \\
\hline DIFICULDADE PARA ACESSAR & 1 & $6 \%$ & - & - \\
\hline GOSTOU DO SISTEMA & 1 & $6 \%$ & - & - \\
\hline Total & 18 & $100 \%$ & 20 & $100 \%$ \\
\hline & FREQU & ÊACIA (\#) & (\# MENÇÕES) & \\
\hline $\begin{array}{l}\text { Você sente-se segura em relação às informações sobre } \\
\text { o caimento da roupa? Não }\end{array}$ & $\begin{array}{c}\text { GRUPO A } \\
\text { DESKTOP/LAPTOP }\end{array}$ & $\%$ & $\begin{array}{l}\text { GRUPO B } \\
\text { SMARTPHONE }\end{array}$ & $\%$ \\
\hline NÃO IDENTIFICOU-SE COM AS FOTOS & 4 & $22 \%$ & 10 & $40 \%$ \\
\hline TERIA QUE EXPERIMENTAR A PEÇA PARA TER CERTEZA & 2 & $11 \%$ & 5 & $20 \%$ \\
\hline NÃO HAVIA INFORMAÇÕES SUFICIENTES & 4 & $22 \%$ & 7 & $28 \%$ \\
\hline INSEGURANÇA A RESPEITO DO FIT FINDER & 1 & $6 \%$ & 1 & $4 \%$ \\
\hline INSEGURANÇA A RESPEITO DAS MEDIDAS FORNECIDAS & 1 & $6 \%$ & 1 & $4 \%$ \\
\hline RISCO PERCEBIDO & 2 & $11 \%$ & 1 & $4 \%$ \\
\hline FALTA DE CONHECIMENTO TÉCNICO SOBRE O ASSUNTO & 2 & $11 \%$ & - & - \\
\hline NÃO GOSTOU DO SITE & 1 & $6 \%$ & - & - \\
\hline OUTROS & 1 & $6 \%$ & - & - \\
\hline Total & 18 & $100 \%$ & 25 & $100 \%$ \\
\hline & FREQU & JÊNCIA ( & (\# MENÇÕES) & \\
\hline $\begin{array}{l}\text { Você sente-se segura em relação às informações sobre } \\
\text { o caimento da roupa? Sim. }\end{array}$ & $\begin{array}{c}\text { GRUPO A } \\
\text { DESKTOP/LAPTOP }\end{array}$ & $\%$ & $\begin{array}{c}\text { GRUPO B } \\
\text { SMARTPHONE }\end{array}$ & $\%$ \\
\hline IDENTIFICOU-SE COM AS FOTOS & 5 & $42 \%$ & 2 & $40 \%$ \\
\hline $\begin{array}{l}\text { SEGURANCCA A RESPEITO DAS INFORMAÇÕES } \\
\text { FORNECIDAS PELO SITE }\end{array}$ & 2 & $17 \%$ & 3 & $60 \%$ \\
\hline BASEOU-SE EM EXPERIÊNCIAS PRÉVIAS DE COMPRAS & 2 & $17 \%$ & - & - \\
\hline $\begin{array}{l}\text { SENTIU-SE SEGURA COM AS INFORMAÇ̃̃ES MAS AINDA } \\
\text { SENTE NECESSIDADE DE EXPERIMENTAR }\end{array}$ & 1 & $8 \%$ & - & - \\
\hline O TAMANHO NÃO REPRESENTOU UM RISCO AO & & $8 \%$ & - & - \\
\hline COMPRAR & 1 & $8 \%$ & - & - \\
\hline PODE COMPRAR E TROCAR & 1 & $8 \%$ & - & - \\
\hline Total & 12 & $100 \%$ & 5 & $100 \%$ \\
\hline & FREQU & UÊNCIA & (\# MENÇõES) & \\
\hline $\begin{array}{l}\text { Com base nas informações disponíveis você tem } \\
\text { segurança de que o tamanho escolhido está correto? } \\
\text { Não. }\end{array}$ & $\begin{array}{c}\text { GRUPO A } \\
\text { DESKTOP/LAPTOP }\end{array}$ & $\%$ & $\begin{array}{c}\text { GRUPO B } \\
\text { SMARTPHONE }\end{array}$ & $\%$ \\
\hline $\begin{array}{l}\text { NÃO CONFIA NAS INFORMAÇÕES FORNECIDAS PELO } \\
\text { SITE }\end{array}$ & 2 & $14 \%$ & 4 & $22 \%$ \\
\hline INFORMAÇÕES INSUFICIENTES & 4 & $29 \%$ & 7 & $39 \%$ \\
\hline TERIA QUE EXPERIMENTAR PARA TER CERTEZA & 1 & $7 \%$ & 2 & $11 \%$ \\
\hline DISPARIDADE DE MEDIDAS & 4 & $29 \%$ & 2 & $11 \%$ \\
\hline INFORMAÇÕES INSUFICIENTES NO FIT FINDER & 1 & $7 \%$ & - & - \\
\hline FIT FINDER NÃO ACHOU UM TAMANHO ADEQUADO & & & 1 & $6 \%$ \\
\hline PARA A VOLUNTÁRIA & - & - & 1 & \\
\hline RISCO PERCEBIDO & 1 & $7 \%$ & 1 & $6 \%$ \\
\hline MEDIDAS OK MAS CAIMENTO É UM PROBLEMA & 1 & $7 \%$ & 1 & $6 \%$ \\
\hline Total & 14 & $100 \%$ & 18 & $100 \%$ \\
\hline & FREQU & JÊNCIA (I & (\# MENÇõ̃ES) & \\
\hline $\begin{array}{l}\text { Com base nas informações disponiveis você tem } \\
\text { segurança de que o tamanho escolhido está correto? } \\
\text { Sim. }\end{array}$ & $\begin{array}{c}\text { GRUPO A } \\
\text { DESKTOP/LAPTOP }\end{array}$ & $\%$ & $\begin{array}{c}\text { GRUPO B } \\
\text { SMARTPHONE }\end{array}$ & $\%$ \\
\hline BASEOU-SE EM EXPERIÊNCIAS PRÉVIAS & 4 & $25 \%$ & 7 & $58 \%$ \\
\hline CONFIANÇA NAS INFORMAÇÕES FORNECIDAS PELO SITE & 10 & $63 \%$ & 2 & $17 \%$ \\
\hline USO DA FITA MÉTRICA & - & - & 1 & $8 \%$ \\
\hline IDENTIFICOU-SE COM AS FOTOS & - & - & 1 & $8 \%$ \\
\hline $\begin{array}{l}\text { NÃO TERIA 100\% DE CERTEZA SÓ FARIA UM } \\
\text { INVESTIMENTO BAIXO }\end{array}$ & - & - & 1 & $8 \%$ \\
\hline MEDIDAS OK MAS CAIMENTO É UM PROBLEMA & 2 & $13 \%$ & - & - \\
\hline Total & 16 & $100 \%$ & 12 & $100 \%$ \\
\hline
\end{tabular}




\section{Apêndice 4}

Questionário AttrakDiff2 ${ }^{\mathrm{TM}}$ 


\section{AttrakDiff2 $^{\mathrm{TM}}$ traduzido para o português}

\section{Sua Opinião}

Na próxima página, você vai encontrar pares de palavras para the auxiliar na avaliação do produto que você acabou de usar. Os pares de palavras representam opostos (não são antônimos), com uma escala de sete pontos entre eles.

Um exemplo:

$$
\text { ruim } \square \square \square \square \square \square \square \text { bom }
$$

A avaliação acima sugere que o produto Ihe agrada mas poderia ser melhorado.

Não pense muito antes de responder. Simplesmente marque a primeira opção que lhe ocorrer.

Talvez alguns dos termos da avaliação não condigam exatamente com o produto. Apesar disso, por favor marque uma opção da escala. Não há respostas certas ou erradas - o que vale é a sua opinião!

(Vire a página...) 


\section{Sua Opinião}

Por favor, nos diga quais são suas impressões sobre o produto que acabou de testar marcando uma das opções na escala entre cada termo em cada linha.

Por favor marque sua opção.

\begin{tabular}{|c|c|c|c|c|c|c|c|c|c|}
\hline & 1 & & 2 & & & 4 & & 7 & \\
\hline humano & $\square$ & $\square$ & $\square$ & $\square$ & $\square$ & $\square$ & $\square$ & máquina & R PQ1 \\
\hline que isola & $\square$ & $\square$ & $\square$ & $\square$ & $\square$ & $\square$ & $\square$ & que conecta & HQI_1 \\
\hline agradável & $\square$ & $\square$ & $\square$ & $\square$ & $\square$ & $\square$ & $\square$ & desagradável & R ATT_1 \\
\hline inventivo & $\square$ & $\square$ & $\square$ & $\square$ & $\square$ & $\square$ & $\square$ & convencional & R HQS 1 \\
\hline simples & $\square$ & $\square$ & $\square$ & $\square$ & $\square$ & $\square$ & $\square$ & complicado & R PQ2 2 \\
\hline profissional & $\square$ & $\square$ & $\square$ & $\square$ & $\square$ & $\square$ & $\square$ & amador & R HQI_2 \\
\hline feio & $\square$ & $\square$ & $\square$ & $\square$ & $\square$ & $\square$ & $\square$ & atrativo & ATT_2 \\
\hline que é prático & $\square$ & $\square$ & $\square$ & $\square$ & $\square$ & $\square$ & $\square$ & que não é prático & R PQ_3 \\
\hline simpático & $\square$ & $\square$ & $\square$ & $\square$ & $\square$ & $\square$ & $\square$ & desagradável & R ATT_3 \\
\hline mal organizado & $\square$ & $\square$ & $\square$ & $\square$ & $\square$ & $\square$ & $\square$ & claro & PQ_4 \\
\hline estiloso & $\square$ & $\square$ & $\square$ & $\square$ & $\square$ & $\square$ & $\square$ & cafona & R HQI_3 \\
\hline previsível & $\square$ & $\square$ & $\square$ & $\square$ & $\square$ & $\square$ & $\square$ & imprevisível & R PQ 5 \\
\hline ordinário & $\square$ & $\square$ & $\square$ & $\square$ & $\square$ & $\square$ & $\square$ & luxuoso & HQI_4 \\
\hline alienador & $\square$ & $\square$ & $\square$ & $\square$ & $\square$ & $\square$ & $\square$ & integrador & HQI_5 \\
\hline me aproxima das pessoas & $\square$ & $\square$ & $\square$ & $\square$ & $\square$ & $\square$ & $\square$ & me afasta das pessoas & R HQI_6 \\
\hline não apresentável & $\square$ & $\square$ & $\square$ & $\square$ & $\square$ & $\square$ & $\square$ & apresentável & HQI_7 \\
\hline não é convidativo & $\square$ & $\square$ & $\square$ & $\square$ & $\square$ & $\square$ & $\square$ & convidativo & AT__4 \\
\hline não é criativo & $\square$ & $\square$ & $\square$ & $\square$ & $\square$ & $\square$ & $\square$ & criativo & HQS_2 \\
\hline bom & $\square$ & $\square$ & $\square$ & $\square$ & $\square$ & $\square$ & $\square$ & ruim & R ATT_5 \\
\hline confuso & $\square$ & $\square$ & $\square$ & $\square$ & $\square$ & $\square$ & $\square$ & claramente estruturado & PQ_6 \\
\hline repele & $\square$ & $\square$ & $\square$ & $\square$ & $\square$ & $\square$ & $\square$ & atrai & ATT_6 \\
\hline ousado & $\square$ & $\square$ & $\square$ & $\square$ & $\square$ & $\square$ & $\square$ & cauteloso & R HQS_3 \\
\hline inovador & $\square$ & $\square$ & $\square$ & $\square$ & $\square$ & $\square$ & $\square$ & conservador & R HQS_4 \\
\hline sem graça & $\square$ & $\square$ & $\square$ & $\square$ & $\square$ & $\square$ & $\square$ & cativante & HQS_5 \\
\hline não é exigente & $\square$ & $\square$ & $\square$ & $\square$ & $\square$ & $\square$ & $\square$ & desafiador & HQS_6 \\
\hline motivador & $\square$ & $\square$ & $\square$ & $\square$ & $\square$ & $\square$ & $\square$ & desencorajador & R ATT_7 \\
\hline original & $\square$ & $\square$ & $\square$ & $\square$ & $\square$ & $\square$ & $\square$ & comum & R HQS_7 \\
\hline descontrolado & $\square$ & $\square$ & $\square$ & $\square$ & $\square$ & $\square$ & $\square$ & controlável & PQ_7 \\
\hline
\end{tabular}


Tabulação dos resultados do AttrakDiff2 ${ }^{\mathrm{TM}}$ : grupo 1

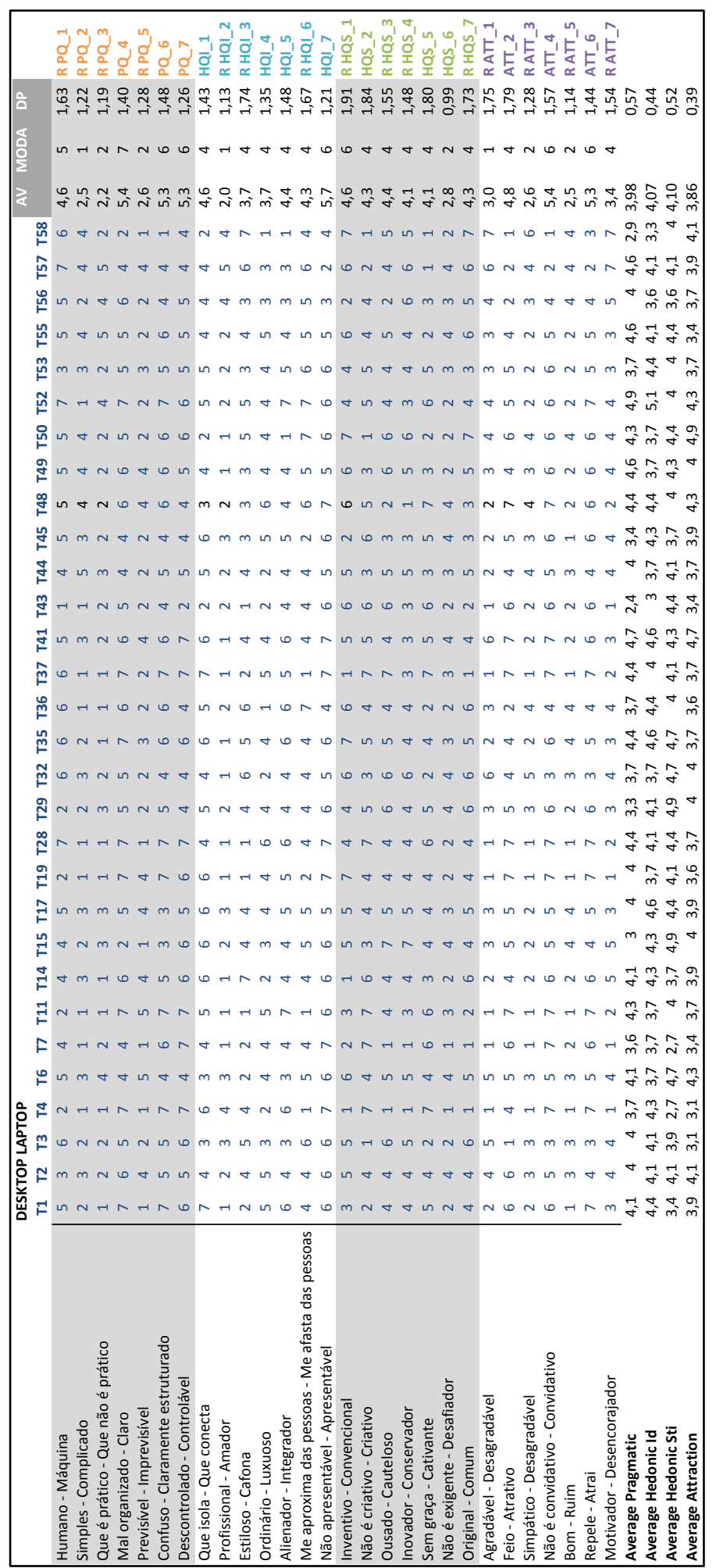


Tabulação dos resultados do AttrakDiff2 $^{\mathrm{TM}}$ : grupo 2

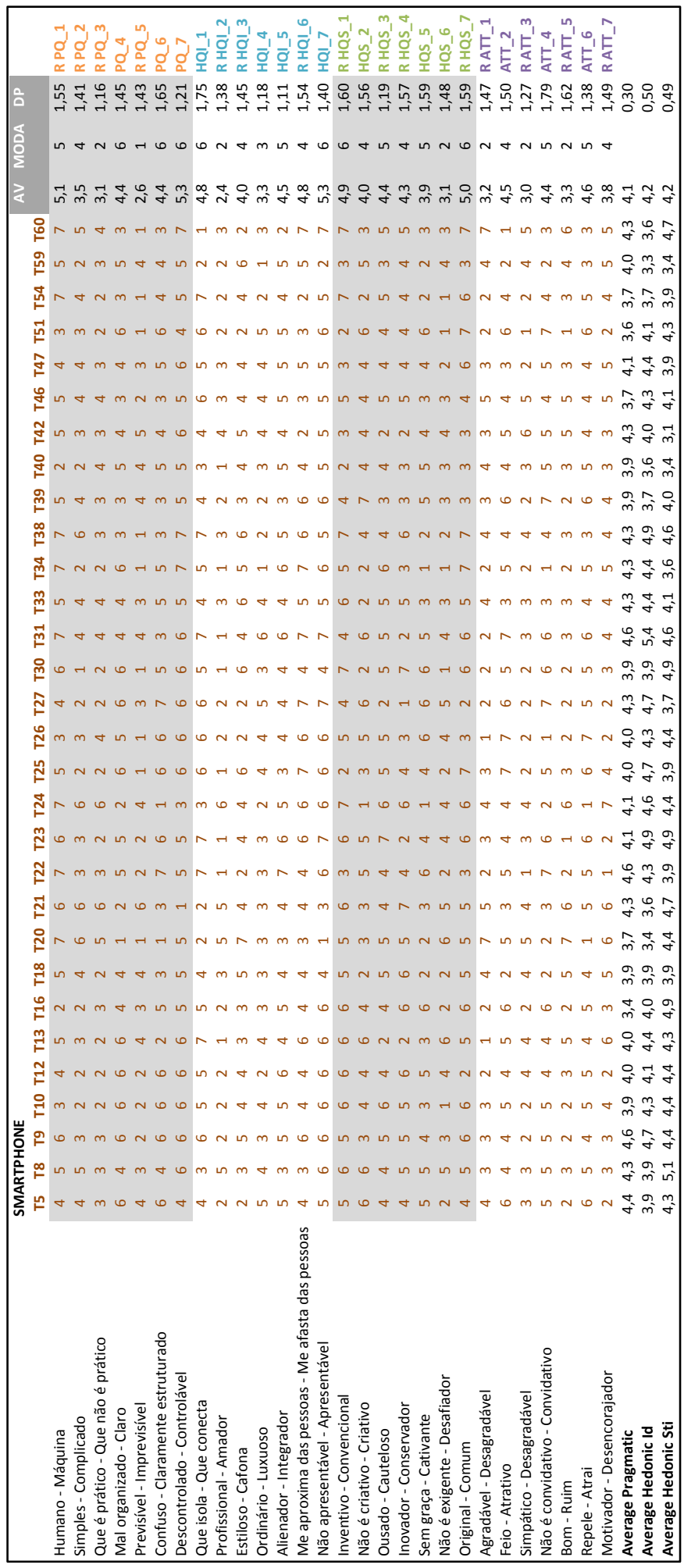


Apêndice 5:

Vestuário 


\section{Tipos de modelagem definidos por Heinrich (2007):}

Modelagem Plana (Bidimensional): É uma técnica utilizada para reproduzir, de forma bidimensional, ou seja, de forma plana, algo que será usado sobre o corpo humano, em tecido ou similar, de forma tridimensional. Essa modelagem, manual ou computadorizada, pode ser utilizada para confeccionar uma peça de roupa apenas ou para produção em grande escala, como acontece na confecção industrial de pequeno, médio ou grande portes.

Moulage (Tridimensional): É a manipulação do tecido de forma tridimensional. Trabalha-se com o tecido sobre os manequins, que têm suas medidas padronizadas. $\mathrm{Na}$ moulage, podem ser feitos os ajustes direto nas curvas do corpo, resultando em um caimento perfeito.

\section{Etapas da construção da roupa:}

As etapas da construção segundo Leite e Velloso (2004) estão ilustradas na Figura 4.3 e descritas a seguir.

ETAPAS DA CONSTRUÇÃO DA ROUPA

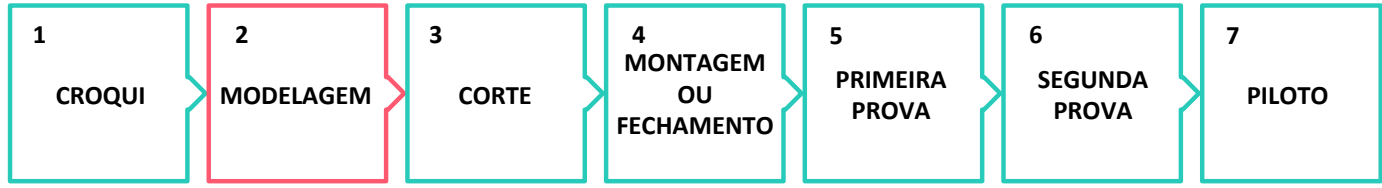

ETAPAS DA REPRODUÇÃO DA ROUPA
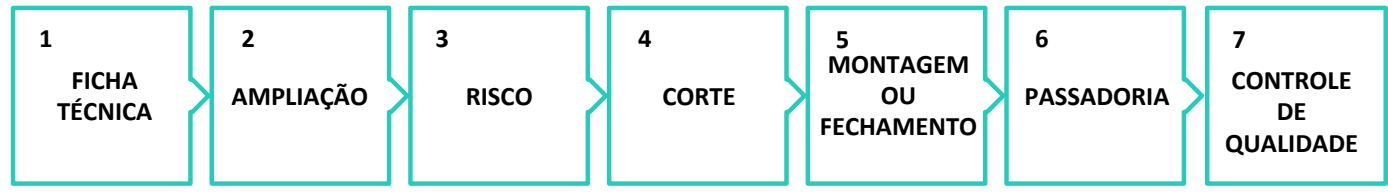

Figura A.1 - Etapas da construção e da reprodução de roupas. Fonte: elaborado pela autora com base em (LEITE; VELLOSO, 2004, p. 144).

- Croqui - Desenho da ideia do modelo, que dá origem a todo o processo;

- Modelagem - Os moldes são desenvolvidos a partir do desenho do estilista obedecendo as medidas da tabela adotada;

- Corte - O tecido é cortado de acordo com os moldes;

- Montagem ou fechamento - As partes cortadas das peças são unidas, passando por operações e máquinas diferenciadas;

- Primeira prova - Prova da roupa em uma modelo ou no manequim, montada sem acabamento; 
- Segunda prova - Prova definitiva, que, depois de aprovada, será a matriz da peçapiloto do modelo;

- Piloto - Nome dado à peça de roupa que servirá de base para reprodução; modelo, protótipo;

- Ficha técnica - Desenho e análise técnica da roupa;

- Ampliação - Os diferentes tamanhos são desenvolvidos a partir do molde inicial, obedecendo a uma escala-padrão;

- Risco - Os diferentes tamanhos são encaixados e riscados no enfesto ${ }^{16}$, buscado o melhor aproveitamento do tecido;

- Corte - O tecido é organizado no enfesto, garantindo o corte em grande quantidades;

- Montagem ou fechamento - Mesmo procedimento da fase de pilotagem, mas em escala industrial;

- Passadoria - As costuras são assentadas e é possível marcar detalhes das dobras, vincos, pregas e caimento; e

- Controle de qualidade - Inspeção feita para garantir que o produto não tenha nenhum tipo de defeito (LEITE; VELLOSO, 2004, p. 144).

\section{Medidas utilizadas na confecção de peças de vestuário}

Heinrich (2007), Matias, (2009) e Silveira (2003) classificam as medidas utilizadas na confecção de peças de vestuário conforme relação abaixo:

Medidas individuais: são as que conseguimos por meio do corpo, individualmente.

Medidas padronizadas: são as medidas que obtemos de tabelas e são utilizadas para construção de moldes nas indústrias de confecções.

Fundamentais - são as medidas horizontais, aquelas necessárias para o traçado das bases. Essas medidas determinarão o tamanho da roupa. São elas: circunferência do busto, da cintura e dos quadris, etc.

Auxiliares - medida do ombro, largura da frente e altura do busto, etc.

Complementares - São aquelas necessárias para transformar o molde básico da roupa. Referem-se aos pormenores do modelo assim como: folgas, comprimento da frente, das costas, da manga, contorno do braço, do pescoço e altura total do corpo, etc.

\section{Medidas utilizadas para contrução de peças de vestuário (Figura A.2):}

\footnotetext{
${ }^{16}$ Enfesto de tecido: é a operação pela qual o tecido é estendido em camadas, completamente planas e alinhadas, a fim de que sejam cortadas em pilhas (AUDACES, 2014).
} 
1a. COMPRIMENTO/ALTURA DA FRENTE - Medida da base do pescoço, passando pelos mamilos até a linha da cintura. Geralmente é 2 a $3 \mathrm{~cm}$ maior que a altura das costas;

1b. COMPRIMENTO/ALTURA DAS COSTAS - Medida de altura, no centro das costas, entre a base do pescoço e a linha da cintura;

2. OMBRO - Medida da base do pescoço à extremidade do ombro;

3. COSTADO/LARGURA DAS COSTAS - Distância entre as cavas nas costas, tomada numa altura correspondente à metade da altura entre o ombro e a dobra da axila. A medida deve ser tirada com os braços cruzados na frente;

4. PESCOÇO - Medida de contorno na base do pescoço;

5. BUSTO - Medida de contorno do corpo na altura dos mamilos;

6. ALTURA DO BUSTO - Distância entre a linha da cintura e a linha do busto (mamilo);

7. SEPARAÇÃO DO BUSTO/DISTÂNCIA DO BUSTO - Distância entre os mamilos;

8. CINTURA - Medida de contorno na altura da cintura. Geralmente, essa altura fica a 2,0 centímetros cima do umbigo para as mulheres e no umbigo para os homens;

9. BRAÇO (LARGURA DO BRAÇO) - Medida de contorno do braço logo abaixo da axila, na parte mais grossa do braço;

10. ALTURA DO COTOVELO - Distância entre o ombro e a ponta do cotovelo, tomada com as mãos apoiadas na cintura e os braços dobrados;

11. COMPRIMENTO DA MANGA - Distância entre o ombro e o punho, tomada com o braço dobrado em um ângulo de $90^{\circ}$;

12. BOCA DA MANGA/PUNHO - Medida utilizada para o traçado da base da manga. Nesse caso, medimos o contorno da mão em vez do punho (pulso) propriamente dito. A medida é tirada na parte mais larga da mão, com os dedos esticados e o polegar encostado na palma. Dessa forma, temos a medida mínima que a boca da manga precisa ter para vestir sem a necessidade de qualquer abertura;

13. ALTURA DO QUADRIL - Distância entre a linha da cintura e a linha do quadril, tomada pela lateral. Geralmente, fica 20 centímetros abaixo da cintura;

14. QUADRIL - Medida de contorno na altura onde o quadril é mais largo. Geralmente, fica 20 centímetros abaixo da cintura;

15. COMPRIMENTO - DA SAIA: é a distância entre a linha da cintura e a linha do joelho, tomada pela lateral; DA CALÇA: Distância entre a linha da cintura e o chão, tomada pela lateral com a pessoa descalça, também corresponde à altura do joelho.

\section{OUTRAS MEDIDAS:}

JOELHO - Medida da circunferência do joelho;

TORNOZELO - Medida da circunferência do tornozelo; 
TÓRAX - Medida de contorno acima do busto e logo abaixo das axilas;

ALTURA DA ENTREPERNA - Distância entre a virilha e o chão. A medida é tomada colocando-se uma régua encostada na virilha, perpendicular ao chão, medindo-se essa distância;

ALTURA DO GANCHO - É a diferença entre a medida 15 (comprimento da calça) e a medida 16 (altura da entreperna).

(BRANDÃO, 1967; CAVALHEIRO; SILVA, 2003; HEINRICH, 2007a).

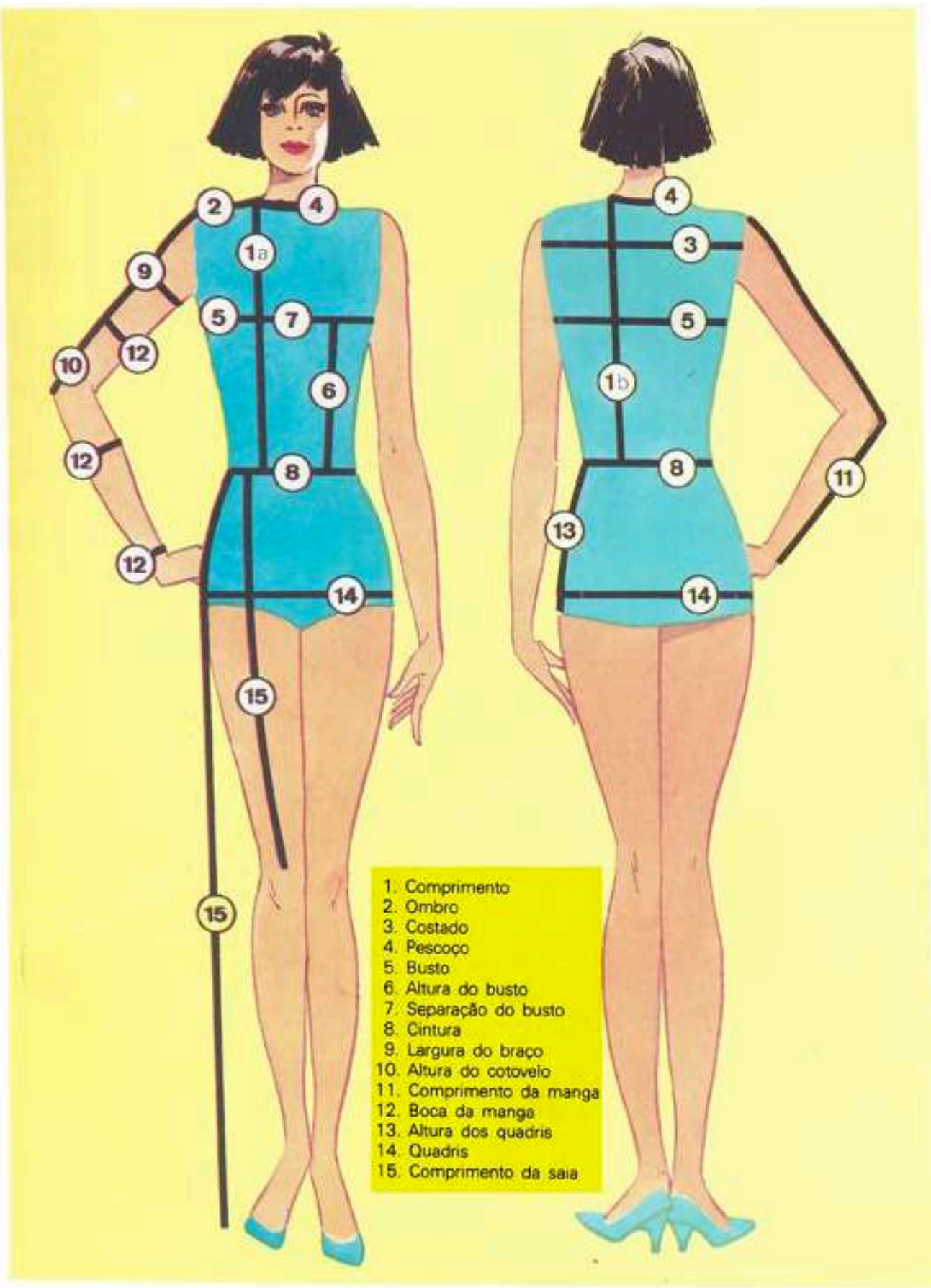

Figura A.2 - Medidas do corpo feminino. Fonte: (BRANDÃO, 1967 p. 11) 


\section{Anexo 1: AttrakDiff2 ${ }^{\mathrm{TM}}$ em inglês}

\section{Your Opinion}

In the following, you will find word pairs that are intended to aid you in assessing the product that you have just become acquainted with. The word pairs represent extreme opposites, with seven graduations possible between them.

An example:

$$
\text { bad } \square \square \square \square \square \square \square \operatorname{good}
$$

The above evaluation example suggests that the product is mainly to your liking, but could stand some improvement.

Do not ponder too long over your response. Just offer the first assessment that enters your mind.

Perhaps some of the assessment terms are not quite suitable to the product. Despite this, however, please checkmark at least one box in the scale. Please consider that there are no "correct" or "incorrect" answers - only your own personal opinion counts!

(See overleaf...) 


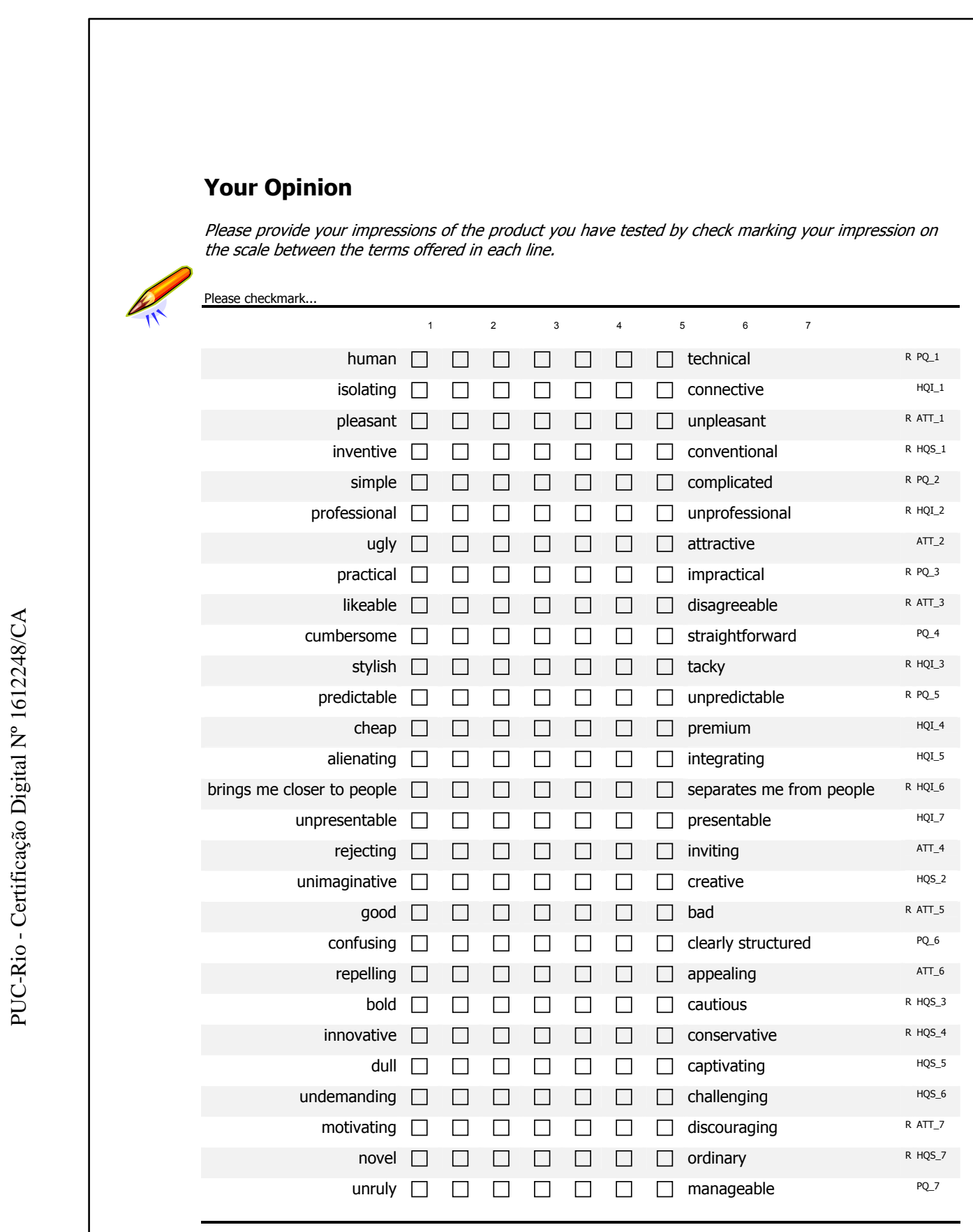

(c) AttrakDiff 2.0 (English), http://www.attrakdiff.de/, Hassenzahl, M. (2004). The interplay of beauty, goodness and usability in interactive products. Human Computer Interaction, 19, 319-349. 


\section{Anexo 2:}

\section{Exemplos de tradução do AttrakDiff2 ${ }^{\mathrm{TM}}$ já utilizados}

\section{Exemplo 1:}

Alienador-Integrador

Amador- Profissional

Cauteloso-Ousado

Chato-Desafiador

Complicado-Simples

Comum-Único

Confuso-Estruturado

Conservador-Inovador

Convencional-Inventivo

Desagradável-Agradável

Desalinhado-Elegante

Desimaginativo-Criativo

Desmotivador-Motivador

Desorganizado-Gerenciável

Distanciador-Aproximador

Entediante-Cativante

Feio-Bonito

Isolador-Conectivo

Não apresentável-Apresentável

Imprevisível-Previsível

Rejeitável-Convidativo

Repulsivo-Sedutor

Ruim-Bom

Técnico-Humanizado

Lira e Tavares (2015)

\section{Exemplo 2:}

Qualidade pragmática

- Humanizado-Técnico

- Simples-Complicado

- Prático-Não prático

- Complicado-Claro

- Previsível-Imprevisível

- Confuso-Bem estruturado

- Desorganizado-Gerenciável

Qualidade hedônica

- Isolador-Conectivo

- Inventivo-Convencional

-Profíssional-Não

profissional

- Elegante-Desalinhado

- Inferior-Superior

- Alienador-Integrador

- Me aproxima das pessoasMe afasta das pessoas

•Não apresentávelApresentável

- Desimaginativo-Criativo

- Ousado-Cauteloso

- Inovador-Conservador

- Entediante-Cativante

- Pouco exigente-Desafiador

- Único-Comum

Apelo

- Agradável-Desagradável

- Feio-Atraente

- Amigável-Não amigável

- Pouco atraente-Atraente

- Bom-Ruim

- Repulsivo-Sedutor

- Motivar-Desencorajador

Cardoso (2013) 
Anexo 3:

Parecer do Comitê de Ética da PUC-Rio

\section{Pontifícia Universidade Católica DO RIO DE JANEIRO}

Câmara de Ética em Pesquisa da PUC - Rio

PARECER DA COMISSÃO DE ÉTICA EM PESQUISA DA PUC-RIO (2017-88)

A Câmara de Ética em Pesquisa da PUC-Rio foi constituída como uma Câmara específica do Conselho de Ensino e Pesquisa conforme decisão deste órgão colegiado com atribuição de avaliar projetos de pesquisa do ponto de vista de suas implicações éticas.

Identificação:

Título: A UX em sítios de comércio eletrônico de vestuário: comparando a experiência móvel com a experiência desktop, um estudo ergonômico. (Departamento de Artes \& Design da PUC-Rio)

Autora: Carolina Marianna Bozzi Faya (Mestranda do Departamento de Artes \& Design da PUC-Rio) Orientadora: Claudia Renata Mont'Alvão Bastos Rodrigues (Professora do Departamento de Artes \& Design da PUC-Rio)

Apresentação: Pesquisa descritiva inserida no campo de estudos em Ergonomia e Usabilidade e Interação Humano - Computador. Trada de questões relacionadas às dificuldades que um usuário enfrenta ao comprar uma peça de roupa por meio de smartphones. Tem por objetivos: identificar os pontos de desconforto $e$ dúvidas referentes à usabilidade em sítio de m-commerce (acesso por meio de dispositivos móveis); analisar os principais obstáculos para a tomada de decisão da compra online: comparar as experiências do uso de um smartphone e de um desktop: por final, elaborar diretrizes para o design de sítios de comércio eletrônico de vestuário feminino, satisfatórios ao acesso via dispositivos móveis. Prevê como métodos e técnicas de pesquisa, além de uma revisão bibliográfica, (a) a aplicação de questionário online com usuários das cinco regiões brasileiras para verificar sua interação com sítios de comércio eletrônico, (b) a realização de entrevista semiestruturada com especialistas em modelagem sobre comércio eletrônico, (c) proceder a testes de usabilidade, após levantamento de sítios da área de moda. O tema da pesquisa é relevante para a área do design, no que diz respeito a usabilidade em sítio de m-commerce e, em particular, ao campo de moda.

Aspectos éticos: $O$ projeto e os Termos de Consentimento Livre e Esclarecido apresentados estão de acordo com os princípios e valores do Marco Referencial, Estatuto e Regimento da Universidade no que se referem às responsabilidades de seu corpo docente e discente. Os Termos de Consentimento Livre e Esclarecido expõem com clareza os objetivos da pesquisa, os procedimentos a serem seguidos e a garantia do sigilo e da confidencialidade dos dados coletados e da identidade dos participantes. Informam sobre a possibilidade de interrupção na pesquisa sem aplicação de qualquer penalidade ou constrangimento.

Parecer: Considerando os elementos expostos acima somos de parecer Favorável à aprovação do projeto quanto aos princípios e critérios estabelecidos pela Comissão de Ética em Pesquisa da PUC-Rio.

Prof. José Riçrdo Bergmann

Presidente do Conselho de Ensino e Pesquisa da PUC-Rio

Rio de Janeiro, 6 de dezembro de 2017

Vice-Reitoria para Assuntos Académicos Rua Marquês de São Vicente, 225 - Gávea - 22453-900. Rio de Janeiro - RJ - Tel. (021) 3527 1619 FAX (021) 35271132. 